Stephen Sirris og Harald Askeland (red.)

\title{
Kirkelig organisering og ledelse
}

Et verdibasert og praksisorientert perspektiv
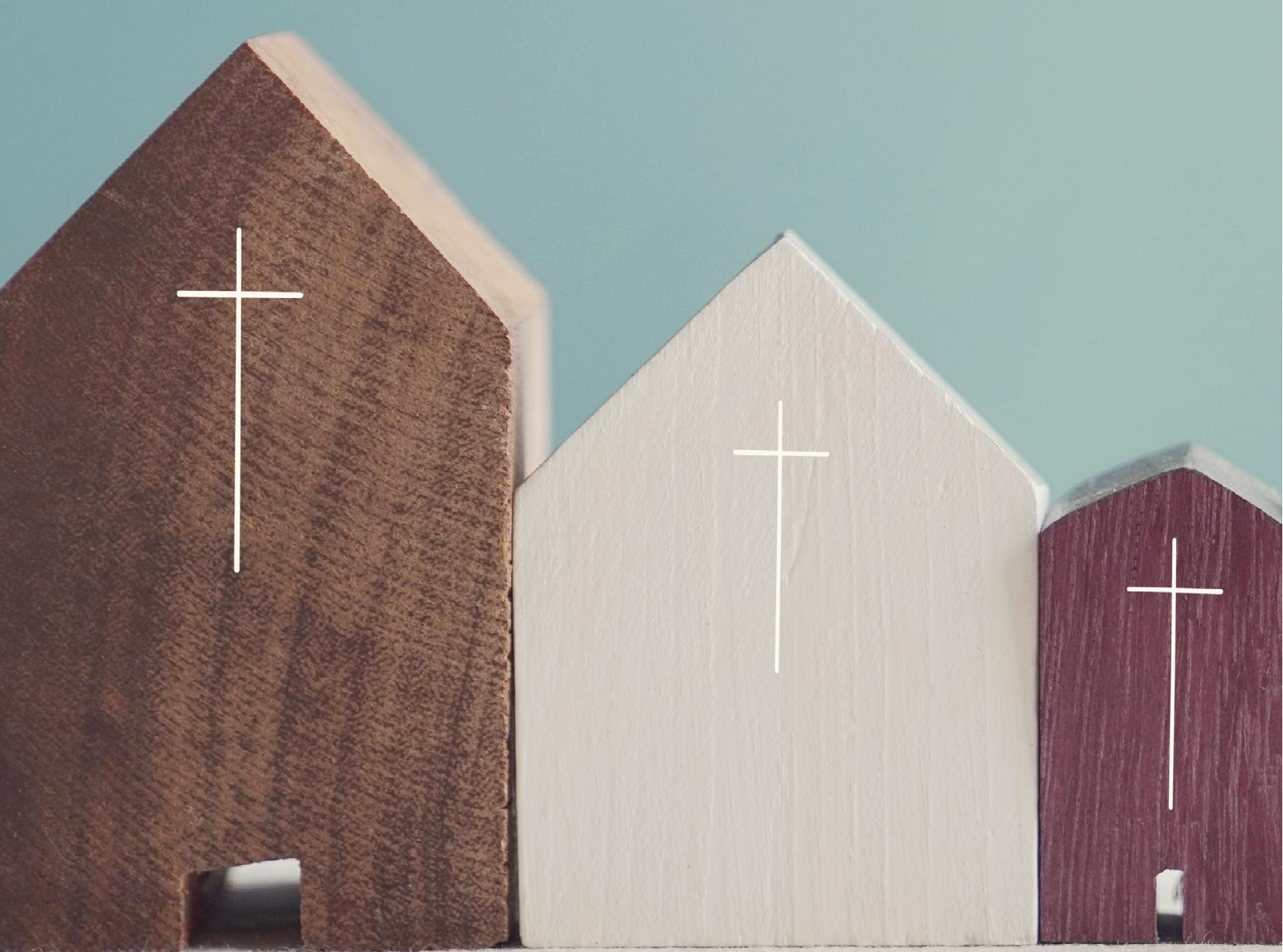

NOASP 
Kirkelig organisering og ledelse 

Stephen Sirris og Harald Askeland (red.)

\section{Kirkelig organisering og ledelse}

ET VERDIBASERT OG PRAKSISORIENTERT PERSPEKTIV 
(C) 2021 Stephen Sirris, Harald Askeland, Mildrid Fiske, Frank Grimstad og Åslaug Styve Mjånes.

Dette verket omfattes av bestemmelsene i Lov om opphavsretten til åndsverk m.v. av 1961. Verket utgis Open Access under betingelsene i Creative Commons-lisensen CC BY-NC-ND 4.o. Denne lisensen lar andre kopiere, distribuere og spre verket i hvilket som helst medium eller format, under forutsetning av at det oppgis korrekt kreditering og lenke til lisens. Dette kan gjøres på enhver rimelig måte, men uten at det kan forstås slik at lisensgiver bifaller deg eller din bruk av verket. Materialet kan ikke benyttes til kommersielle formål. Dersom du remixer, bearbeider eller bygger på materialet, kan du ikke distribuere det endrede materialet.

Lisensvilkår: https://creativecommons.org/licenses/by-nc-nd/4.o/deed.no

Boka er utgitt med støtte fra VID vitenskapelige høgskole.

ISBN trykt bok: 978-82-02-71990-6

ISBN PDF: 978-82-02-70623-4

ISBN EPUB: 978-82-02-723866

ISBN HTML: 978-82-02-723859

ISBN XML: 978-82-02-723873

DOI: https://doi.org/10.23865/noasp.129

Dette er en fagfellevurdert antologi.

Omslagsdesign: Cappelen Damm AS

Omslagsbilde: Getty Images / Thitaree Sarmkasat. Forsideillustrasjonen er ikke omfattet av CC-BY-NC-ND 4.o-lisens, og kan ikke gjenbrukes uten tillatelse fra Getty Images / Thitaree Sarmkasat.

Cappelen Damm Akademisk/NOASP

noasp@cappelendamm.no 


\section{Innhold}

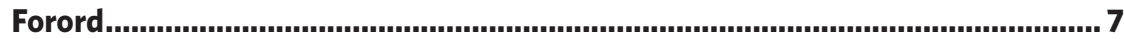

Kapittel 1 Introduksjon til kirkelig organisering og ledelse.

Et verdibasert og praksisorientert perspektiv

9

Stephen Sirris og Harald Askeland

Del I Kirkelig organisering

33

Kapittel 2 Kirken som organisme og organisasjon.

Ekklesiologiske og organisasjonsteoretiske

perspektiver på kirken som felleskap

Stephen Sirris og Harald Askeland

Kapittel 3 Utviklingstrekk i organisering og ledelse i

Den norske kirke

Stephen Sirris, Harald Askeland og Frank Grimstad

Kapittel 4 Forskningsperspektiver på kirke og menighet

som organisasjon

Harald Askeland

Kapittel 5 Demokrati i kirke og menighet 107

Frank Grimstad

Kapittel 6 Institusjonelle rammer for kirkelig ledelse

Frank Grimstad

Del II Kirkelig ledelse 155

Kapittel 7 Ledelse - generelle og kirkelige perspektiver. 157 Harald Askeland

Kapittel 8 Lederskapets kirkelighet. En integrert modell

for verdibevisst kirkelig ledelse 179

Harald Askeland 
Kapittel 9 Roller, identitet og ledelse i praksis ........................................... 201 Stephen Sirris og Harald Askeland

Kapittel 10 Kirkevergens lederrolle 223

Harald Askeland, Mildrid Fiske og Åslaug Styve Mjånes

Kapittel 11 Personalkonflikter i kirkens arbeidsmiljø som en ledelsesutfordring .243

Stephen Sirris og Frank Grimstad

Om forfatterne 267 


\section{Forord}

Denne boken springer ut av flere kilder. En viktig ressurs har vært vår undervisningserfaring ved masterprogrammet i verdibasert ledelse ved VID vitenskapelige høgskole. I tillegg har høgskolen i en årrekke hatt flere undervisningsoppdrag for kirkelige og diakonale organisasjoner. Dessuten har vi, både gjennom egen forskning og veiledning av masterstudenter, ervervet viktig empirisk innsikt som gir grunnlaget for å utvikle en alternativ presentasjon av generelle teoretiske perspektiver som treffer den kirkelige kontekst. Vi som er redaktører har arbeidserfaring fra Den norske kirke, og kan også trekke veksler på verv vi har hatt i ulike råd og utvalg.

En særlig målgruppe for boken vil være studenter ved utdanningene som kvalifiserer til kirkelig tjeneste, eksempelvis teologi, diakoni, kirkelig undervisning og kirkemusikk. Videre vil også andre yrkesgrupper som peiler seg inn på arbeid i kirken, ha utbytte av boken. Boken skal kunne favne og leses av alle som har kirkelig lederstilling. I tillegg skrives denne boken også for praktikere som allerede jobber i kirken. Kapitlene gir et utenfraperspektiv og belyser deres arbeidsvirkelighet og erfaringer. Personer med verv i menighetsråd og fellesråd vil også ha utbytte av boken. For organisasjons- og ledelsesforskere vil boken gi en innføring i kirkefeltet og kirkekonteksten.

Vi som er redaktører har vært aktive forfattere av kapitlene. I tillegg vil vi takke øvrige forfattere, Frank Grimstad, Mildrid Fiske og Åslaug Styve Mjånes, for samarbeidet. Underveis i arbeidsprosessen med boken har vi fått verdifulle innspill på kapittelutkast fra professor Arild Wæraas ved VID samt fra fagsjef i Den norske kirkes presteforening, Per Kristian Aschim. Vi retter også en takk til Frank Grimstad og Leif Stapnes, som er kolleger ved VID, og professor Harald Hegstad ved MF vitenskapelig høyskole, som har gitt respons på enkeltkapitler. En anonym fagfelle har gitt konstruktive kommentarer til inspirasjon i skrivearbeidet. Vi takker 
VID vitenskapelige høgskole ved rektor Bård Mæland og Hilde Trygstad, seksjonsleder for bibliotek, forskningsdatahåndtering og arkiv, for støtte og tilrettelegging av Open Access.

Sist vil vi takke Cappelen Damm Akademisk og redaktørene Simon Aase og Ann Kristin Gresaker for godt samarbeid.

Arne Erik Sæther beskriver kirken i et dikt som har fått plass i Norsk salmebok, nummer 561:
Midt i vår verden, her hvor vi bor, står et bygg som et tegn på vår tro. Lyset og mørket, himmel og jord, møtes her i en levende bro.
Midt i vår verden, her hvor vi bor, kommer Kristus som morgenens gry. Vi er hans kirke, vi er det bygg som han reiser på ny og på ny.

VID vitenskapelige høgskole, Oslo, april 2021

Stephen Sirris og Harald Askeland 


\title{
KAPITTEL 1
}

\section{Introduksjon til kirkelig organisering og ledelse. Et verdibasert og praksisorientert perspektiv}

Stephen Sirris

VID vitenskapelige høgskole

\section{Harald Askeland}

VID vitenskapelige høgskole

\begin{abstract}
This chapter introduces the subject matter of this book - church organizing and leadership - and key concepts. The book's point of departure is recent reforms in the Church of Norway as well as broader cultural and societal changes. This chapter answers the question: How can organization and leadership in the Church of Norway be understood as values-based and practice-oriented? We provide a conceptual framework that serves as the epistemic anchoring of this anthology. First, an institutional values-based approach (Selznick, 1957) takes into account the values and identity of the church as a religious organization. Second, a practice-oriented approach (Mintzberg, 2009), grounded in empirical studies, emphasizes how practices are performed and understood by individual leaders and collectives. These main perspectives facilitate our contextual interest in the Church of Norway focusing on the congregational level embedded in various other levels and interactions between various actors, including leaders, clergy and lay people. We position the individual chapters within the conceptual framework of the book before summarizing its key contributions.
\end{abstract}

Keywords: church, context, leadership, management, organizing, practice-oriented, values-based

\section{Introduksjon}

Denne boken beskriver utvalgte sider ved kirkelig organisering og ledelse ved å presentere og analysere relevante nyere norske forskningsbidrag. ledelse. Et verdibasert og praksisorientert perspektiv. I S. Sirris \& H. Askeland (Red.), Kirkelig organisering og ledelse: Et verdibasert og praksisorientert perspektiv (Kap. 1, s. 9-31). Cappelen Damm Akademisk. https:// doi.org/10.23865/noasp.129.ch1

Lisens: CC BY-NC-ND 4.0 
Vi velger et verdibasert og praksisorientert faglig perspektiv som bokens rammeverk. I dette kapitlet drøfter vi denne forankringen ved å svare på det grunnleggende spørsmålet: Hvordan kan organisering og ledelse i Den norske kirke forstås som verdibasert og praksisorientert? Vi gir først en litteraturoversikt over empiriske studier av organisasjon og ledelse i Den norske kirke, for deretter å belyse fenomenet kirkelig organisering og ledelse gjennom de to begrunnede perspektivene. Med intensjon om å vise relevansen av dette rammeverket, drøfter vi forholdet mellom en verdibasert og en praksisorientert tilnærmingsmåte ved å trekke inn bidrag fra bokens kapitler der det er naturlig. Konklusjonen påpeker bokens samlede bidrag.

\section{En kirke i endring}

Den norske kirke har siden 1990-tallet gjennomgått betydelige endringer. Kirken har utviklet en mer omfattende virksomhet med flere ansatte innenfor en styrket forvaltningsorganisasjon. Prosessen skjøt fart med $ø$ kende delegering av oppgaver fra offentlige til kirkelige organer. Sentrale milepæler var selvstendiggjøringen av soknet fra kommunene i 1997 og fristillingen av folkekirken fra staten i 2017 (Askeland \& Schmidt, 2016). Denne utviklingen har vært intendert og styrt ved å være basert på indrekirkelige reformkrav og vedtak i Stortinget. I et norsk kirkehistorisk perspektiv utgjør opphøret av statskirkeordningen den største endringen siden reformasjonen (Dietrich et al., 2011).

I tillegg til ordningsmessige endringer har kirken gjennomført reformer på sentrale virksomhetsområder. Trosopplæringsreformen har satt spor i nye arbeidsmåter og stillingskategorier (Botvar et al., 2015). Gudstjenestereformen har vært omfattende og fremmet verdier som fleksibilitet, involvering og stedegengjøring (Botvar \& Mosdøl, 2014). Videre er kirkens styrkede oppmerksomhet på frivillighet støttet av en offentlig diskurs preget av verdier som medbestemmelse, delaktighet og demokrati (Sporsheim \& Sirris, 2018). Innad i kirken har tydeligere lederroller vokst frem lokalt etter kirkelovens (1996) etablering av stillinger som daglig leder og kirkeverge (Askeland, 2016b). Prostereformen fra 2004 styrket prostenes lederrolle overfor prestene. Opphøret av prestenes boplikt i 2015 og innføringen av mer regulert arbeidstid i 2016 bidro til å 
omforme prestetjenesten til et moderne yrke (Sirris, 2019b). Det pågående kirkeordningsarbeidet utreder forholdet mellom kirkens styringsnivåer og samordning av to arbeidsgiverlinjer med felles arbeidsgiverorgan og enhetlig ledelse i lokalkirken. Mens dette skrives våren 2021, er fortsatt mye i støpeskjeen. Kirken vil trolig være i omforming også i årene som kommer, og det er ikke sikkert at endringstakten kommer til å avta.

Disse parallelle prosessene setter i økende grad spørsmålet på dagsordenen: Hvordan kan kirken best organiseres og ledes? Mens kirkelig organisering, styring og ledelse tradisjonelt har vært sett på som et underordnet spørsmål om hensiktsmessighet, omtalt som adiaforon, har organisasjonsbygging og selvstendiggjøring aktualisert tematikken. Med en lang periode av delegering og den senere tids fristilling, fremstår Den norske kirke og menighetene tydeligere som selvstendige organisasjoner. Ekspansjonen av demokratiske organer, forvaltningsorganisasjon samt nye tiltak og tjenestegrupper, gir nye samhandlingsmønstre. Disse dynamikkene finner ikke sted i et indrekirkelig tomrom. Derimot er det flere dypereliggende utviklingstrekk i samfunnet hvor kirken inngår som innbyr til fornyet drøfting av kirkelig organisering (Schmidt, 2016). I et større perspektiv har Norge i etterkrigstiden erfart en overgang fra en luthersk enhetskultur til et sekularisert og pluralistisk samfunn (Furseth, 2015; Repstad, 2020). Dette gradvise skiftet uttrykkes ved at kirkeloven av 1996 ble erstattet av lov om tros- og livssynssamfunn (trossamfunnsloven) i 2021. Kirken utfordres dermed til å avklare hvilken rolle den vil spille i samfunnet og hvordan den skal samhandle med omgivelsene. Overgangen aktualiserer interaksjon mellom frivillige og profesjonsutøvere i menigheten samt et intensivert arbeid med utvikling og innovasjon.

Utviklingstrekkene vi har beskrevet så langt bør følges opp av relevant og faglig forankret refleksjon om organisering og ledelse. Dette er et behov denne boken har som formål å imøtekomme. Den norske kirke er en kompleks organisasjon som inneholder et mangfold av eksempler på ulike organisasjons- og ledelsesformer. Mens en organisasjon forstås som et sosialt system bevisst konstruert for å løse spesielle oppgaver og for å realisere bestemte mål (Jacobsen \& Thorsvik, 2019), defineres ledelse grunnleggende som en innflytelsesprosess som sikter på å oppnå mål gjennom andre (Yukl, 2013). Vi argumenterer i boken for at kirkens 
mangfold er svært interessant for organisasjons- og ledelsesfaget. Det gjør vi ved å belyse kirken med teori og begreper fra dette fagfeltet. På tross av kirkens potensielle interesse for fagfeltet, ikke minst på grunn av endringene den står i, synes trosbaserte og religiøse organisasjoner fortsatt å være understudert. Det gjelder også internasjonalt (Jeavons, 2004; Torry, 2017; Tracey et al., 2014). Denne antologien er en respons på mangelen, og gir et vitenskapelig bidrag med Den norske kirke som forskningsobjekt.

\section{Kort faghistorie og litteraturoversikt}

Dette delkapitlet gir en innføring i fagfeltet kirkelig organisering og ledelse. Til tross for at Den norske kirke er landets eldste organisasjon, landsomfattende og med $69 \%$ av befolkningen som medlemmer i 2020, foreligger det relativt få empiriske forskningsbidrag om kirkelig organisering og ledelse. Likevel har praksisfeltet vist interesse for temaet. Det gjenspeiles ved at tidligere Diakonhjemmet høgskole, nåværende VID vitenskapelige høgskole, siden 1974 har tilbudt en lederutdanning for kirkelige og diakonale ledere. Fra 1980-tallet har det vært gjennomført ulike kurs for sokneprester i regi av Den norske kirkes presteforening, etter hvert med betegnelsen pastoral lederutvikling, i samarbeid med de teologiske fakultetene. I 1990 etablerte KA Kirkens arbeidsgiver- og interesseorganisasjon kurs for folkevalgte i menighetsråd og kirkelig fellesråd, samt for kirkeverger. Siden 2004 har det, som del av VIDs mastergradsprogram i verdibasert ledelse, vært mulig å ta mastergrad i ledelse med en kirkelig spesialisering. Praksisfeltets behov og voksende interesse for ledelse har gjort at ledelsesemner er integrert i flere kirkelige profesjonsutdanninger.

En av de tidligste bidragsytere på feltet kirkelig organisering og ledelse, sivilingeniøren Roar Mjelva (1979a, 1979b), skrev to artikler: «Kirken som sosio-religiøst system» og «Styring i kirken». Her presenterte han en systemmodell av kirken og tok til orde for at kirkelig virksomhet burde målstyres. Målstyring vektlegger at ledelsen fastsetter distinkte mål for virksomheten. Målene følges opp av adekvate virkemidler og definering av ansvar. Gjennom tallfesting dokumenteres i hvilken grad målene nås, noe ledelsen får tilgang til gjennom rapportering. Disse to tidsaktuelle 
og allmenne organisasjonsteoriene ble applisert på kirken. Systemteori, som vektla indre sammenhenger mellom strukturer og aktører i tillegg til organisasjoners forhold til omgivelsene, var også det naturlige utgangspunkt for to forskere ved Diakonhjemmet høgskole, Morten Skjørshammer og Einar Aadland (1991). De gikk et skritt videre enn Mjelva og argumenterte for at kirkefeltet burde utforskes organisasjonsfaglig, men med særlig henblikk på organisasjonens egenart (Skjørshammer \& Aadland, 1991). Dermed påpekte de at allmenne og kontekstuelle trekk ved organisasjoner måtte sammenholdes. Få år senere kom den første forskningsrapporten om lokalkirkelig utvikling som tematiserte styrings- og ledelsesroller (Aadland, 1994).

I forbindelse med stortingsbehandlingen av ny kirkelig lovgivning midt på 1990-tallet, utgav KA arbeidsorganisasjon for kirkelige virksomheter ressursbøker om kirkelig organisering og ledelse. Der ble allmenn ledelsesforståelse anvendt på kirkelige lederroller og alternative modeller for organisering av ledelsesfunksjonen i lokalkirken (Grimstad \& Askeland, 1996). Med lovfesting av kirkelig fellesråd og kirkevergefunksjonen i 1996, økte forskningsinteressen sammen med en fornyet oppmerksomhet på ledelse av prestetjenesten. KIFO, Institutt for kirke-, religions- og livssynsforskning, gjennomførte i årene etter innføringen av kirkeloven flere større forskningsprosjekter som tematiserte lokale kirkelige lederroller og ledelse av prestetjenesten (Huse, 1998; Askeland, 1998). KIFO har i en årrekke vært sentral hva gjelder empiriske studier av kirken, både med hensyn til utforsking av temaet prest og ledelse, men også med en tidlig evaluering av prostereformen. Denne reformen ble initiert i 2004, da prostiet ble etablert som tjenestedistrikt for prester med prosten som nærmeste leder.

Innenfor praktisk teologi har den empiriske vendingen medført at samfunnsvitenskapelige metoder brukes for å utforske menigheter (Hegstad, 1996, 1999). Ledelsestematikken har hatt en økende interesse innenfor praktisk teologi med både teoretiske og empiriske bidrag (Skjevesland, 1994, 1998). I denne perioden initierte KIFO flere faglige bidrag med utgangspunkt i teologi som ble samlet i antologien Prest og ledelse (Huse, 200o). Blant de kirkelige stillingskategoriene, er prestene gjennomgående viet størst forskningsinteresse (Sirris, 2016). Et bidrag som reflekterer over 
presters lederrolle ut fra deres sentrale liturgiske og forkynnende funksjoner, tematiserer presten som symboliserende, strategisk og samhandlende leder (Saxegaard, 2009). I 2015 ble det etablert et tidsskrift med forankring i frikirkelige kirkesamfunn, Scandinavian Journal for Leadership and Theology. Fag- og forskningsinteresse for ledelse i religiøse organisasjoner har et bredere nedslagsfelt enn Den norske kirke.

I 2003 utkom boken Ledelse i kirken (Hougsnæs et al., 2003) som vi anser som et viktig utgangspunkt for herværende bok. Boken ble utgitt av KA og trakk veksler på allmenn teori innenfor organisasjons- og ledelsesfagene. Den representerer et tidlig bidrag som anvender og begynner en kontekstualisering av disse i kirkelig kontekst. Boken har vært mye benyttet i kurs og undervisning for kirkeledere. Siden den gang har kirkelig organisering og ledelse blitt etablert som et delområde innen organisasjons- og ledelsesfaget. Ikke minst har det vært empirisk forskning på dette feltet etter 2003 som alle kapitlene i denne boken trekker veksler på. Som vår oversikt viser, fremstår bidragene hittil som fragmenterte. Denne boken representerer en sammenstilling og videreutvikling. Gitt omfanget av endringer som vi skisserte innledningsvis, er en mer enhetlig oppdatering viktig.

Det gryende fagfeltet kirkelig organisering og ledelse har dermed utviklet fornyede perspektiver og blitt tilført teoretiske begreper som gir nyttige verktøy for å analysere utviklingen i og av kirkeorganisasjonen. Denne bokens anliggende er ikke å foreta en ukritisk import fra organisasjons- og ledelsesfaget inn i kirkelig kontekst. Derimot argumenterer vi for at forskningsinnsatsen siden 1990-tallet har bestått i en kontekstualisering som gir selvstendige og relevante innspill til kirkelig organisering og ledelse som et distinkt fagområde. En slik kontekstsensitivitet ivaretas gjennom det vi har valgt som denne bokens teoretiske rammeverk: verdibasert ledelse (Aadland \& Askeland, 2017), som er fundamentert i institusjonell teori (Hampel et al., 2017; Johansen \& Waldorff, 2017), og praksisstudier av kirkelige ledere (Askeland, 2016a; Sirris, 2019a). Vi ser derfor herværende bok som en gjennomgang av begge områder og som sammenstilling av kunnskap med et særskilt fokus: Den empiriske utforskningen av kirkefeltet med studier av organisering og ledelse muliggjør en dialog mellom det særegne i kirkekonteksten og allmenn 
forskningslitteratur og teoriutvikling. Vårt rammeverk legger til rette for en slik samtale. I tråd med innretningen på forskningen som er presentert så langt, er det også denne bokens anliggende å balansere det generelle og det kontekstuelle på feltet kirkelig organisering og ledelse. Dette gjør vi gjennom et forsøk på å finne en felles arena for ekklesiologiske perspektiver og organisasjons- og ledelsesfagene (Hegstad, 2009). Boken vil dermed være en ressurs for videre fagutvikling. I det følgende utdyper vi bokens faglige innretning ved å drøfte det teoretiske rammeverket.

\section{Bokens faglige innretning og teoretiske rammeverk}

Organisasjons- og ledelsesfaget er omfattende. Vi har derfor valgt å avgrense dette kapitlet til to utvalgte hovedperspektiver som bidrar til å profilere bokens prosjekt. Ut over dette innledningskapitlet er boken todelt, og tar henholdsvis for seg kirkelig organisering (kapittel 2-6) og kirkelig ledelse (kapittel 7-11). Den første hoveddelen av boken tematiserer ulike trekk ved kirken som er av betydning for virksomheten og som legger føringer for ledelsespraksis. I del to har de første kapitlene et tydelig teoretisk preg, mens de siste presenterer og drøfter ulike lederroller og lederkategorier på grunnlag av empiriske studier. Begge de to hovedperspektivene, et institusjonelt verdibasert og et praksisorientert syn på organisering og ledelse, er tydelige i alle kapitlene eksplisitt eller som underliggende premiss. I det følgende presenterer vi disse perspektivene samt sentrale begreper som vil gå igjen i enkeltkapitler, og drøfter deres relevans for å forstå historiske og pågående prosesser i Den norske kirke.

\section{Kirkelig organisering og ledelse i et institusjonelt verdibasert perspektiv}

Det er ikke likegyldig hvordan kirkens ordninger regulerer virksomheten. Selv om kirkelig organisering i lutherske kirker tradisjonelt omtales som et spørsmål om hensiktsmessighet, er det likevel en utbredt oppfatning at Den norske kirkes oppdrag og identitet legger føringer for tjenlig praksis og organisering (Aarflot, 1990). Dette utgangspunktet gir en 
retning for hva slags kompetanse, hvilke stillinger og ledelsesfunksjoner som bør være på plass for at kirken skal kunne realisere sitt kall. Vårt normative ståsted i denne boken er å fastholde at kirkelig organisering må forankres i kirkens oppdrag. Sagt på en annen måte: kirken gjør hva den er, og organiserer hva den gjør. Dette anliggendet behandles i kapittel 2, der Stephen Sirris og Harald Askeland tar utgangspunkt i at Den norske kirke kan forstås ut fra en rekke perspektiver grunnet kirkens kompleksitet og mangfoldige funksjoner. Forfatterne undersøker hvordan ekklesiologi, læren om kirken, og organisasjonsteori forstår kirken som fellesskap med både organisatoriske og organiske trekk. Kapitlet har en tydelig teologisk forankring gjennom to ekklesiologiske tradisjoner som betoner de bibelske begrepene communio (fellesskap eller delaktighet) og ekklesia (forsamlingen eller kirken). Når kirken beskrives som et kollektiv eller fellesskap, brukes gjerne metaforene organisasjon og organisme som en motsetning. Begge fagområdene har til felles at de vektlegger kirken som et sosialt kollektiv som møtes for særlige religiøse formål. Kapitlet presenterer relevante innsikter fra begge disipliner gjennom å analysere sentrale bidrag som muliggjør en tverrfaglig samtale. Forfatterne argumenterer for at flere faglige perspektiver er nødvendig for å forstå og utvikle kirkelig organisering.

\section{Verdier}

I et større historisk og globalt perspektiv er spørsmålet om tjenlig kirkeorganisering blitt besvart på mange ulike måter. Men tar vi utgangspunkt i Den norske kirke, er kirkens visjon en veiviser. Kirken ønsker å være en «bekjennende, misjonerende, tjenende og åpen folkekirke». Disse verdiene angir retningen, men ingen klart definerte mål. Menighetene kan vektlegge ulike sider av disse verdiene ettersom menighetene har forskjellige preg avhengig av geografiske og kulturelle forhold. At kirken er både landsdekkende og demokratisk, åpner et fortolkningsmangfold. Kirkedemokratiet har vært et premiss for opphøret av statskirkeordningen og fristillingen av folkekirken. Verdien demokrati tematiseres i kapittel 5. Frank Grimstad drøfter Den norske kirke som en demokratisk kirke, og analyserer hva denne verdien betyr og hvilke følger den har for organisering og ledelse. Kapitlet bidrar med ny oversikt over ulike 
konseptualiseringer av kirke og demokrati både historisk og i vår samtid. Balansen mellom vigslede og lekfolk i styringsorganene blir tatt opp som et viktig demokratisk anliggende. Grimstad poengterer at en demokratisk kultur i styringen av lokalkirken er avhengig av sentrale verdier i lokalsamfunnet. Men fremdeles er det et potensial for å engasjere medlemmene til å ta større ansvar for kirken. Avslutningsvis leveres et bidrag til forståelse av hvordan ledere kan medvirke til god demokratisk styring i og av kirkeorganisasjonen.

Selv om boken ikke primært er normativt orientert, har alle kapitlene et tydelig verdiperspektiv. Et verdibasert perspektiv er naturlig fordi kirken er en religiøs organisasjon. Organisasjonsidentitet kan forstås som varige, sentrale og distinkte trekk. Verdier antas å være et kjerneelement ved en organisasjons selvforstålse (Pratt \& Ravasi, 2016). Det innebærer at kirken er basert på en tro som impliserer verdier. Religiøse organisasjoner ble grunnlagt for å uttrykke grunnleggerens verdier (Carroll, 1991). Kirken har dels beholdt sitt verdigrunnlag gjennom sin lange historie, samtidig som det har skjedd utvikling og tilpasninger i samspill med kontekst og samtid. I land med langvarig kristen kultur, er kristne og allmenne verdier i høy grad blitt likedannet. Hva som er spesifikt kristne verdier, er derfor ikke gitt. Mange vil peke på eksempelvis barmhjertighet, tilgivelse, rettferdighet og likeverd. Dette er grunnleggende verdier som kirken fremmer, der kirkens ledere er bærere av dem. Harald Askeland (2020, s. 26) definerer verdibegrepet slik (vår oversettelse):

Verdier er individuelle og kollektive oppfatninger om ønskelig atferd på tvers av situasjoner, mål og idealer som gir retning for eller evaluerer praksis. Implisitt i definisjonen inngår at verdier 1) eksplisitt eller implisitt er kontekstuelle og situert i tid og rom, 2) tjener til å mobilisere og gi retning for handling, 3) er ikke mulig å observere, men blir manifestert i eller gjennom refleksjon over praksis, 4) tilegnes gjennom sosialisering i grupper eller gjennom utprøvende læring, 5) blir konstituert, opprettholdt og endret i dialektisk interaksjon mellom individet og kollektivet, 6) også når verdier er delt de de er tvetydige og åpne for fortolkning.

Med dette som utgangspunkt, står mange av artiklene i en institusjonell teoretisk tradisjon (Scott, 2014; Selznick, 1957), blant annet utviklet 
i rammen av verdibevisst ledelse (Aadland \& Askeland, 2017). Utviklingen av verdibevisst ledelse har nettopp kombinert forskning på ledelse som praksis og søkt å integrere ledelsespraksisers verdiforankring med den amerikanske sosiologen Phillip Selznicks forståelse av institusjonelt lederskap. Institusjonalisme er kun en av svært mange retninger innenfor organisasjonsforskningen. Institusjonell teori utgjør ingen enhetlig tilnærmingsmåte, men er heller en samlebetegnelse som rommer ulike, men beslektede perspektiver hvor kontekst og omgivelser er en fellesnevner. Organisasjoner er i dialog med og formes av sin institusjonelle kontekst (Scott, 2014). Når organisasjoner over tid opererer i den samme institusjonelle konteksten påvirkes de av ulike likedanningsprosesser, enten av legal, normativ eller kulturell-kognitiv karakter. Det første betegner den juridiske siden, regulering gjennom lovverket. Det normative handler om forventninger i omgivelsene til hva som er kulturelt passende atferd i samsvar med verdier i og utenfor organisasjonen. Det kulturelt-kognitive refererer til det som tas for gitt og sjelden stilles spørsmål ved i en gitt kontekst. Alle organisasjoner er avhengige av en viss legitimitet fra sine omgivelser, og likedanning innebærer at man oppnår anerkjennelse ved at organisatorisk praksis, for eksempel organisering og styring, fremstår som lik i henhold til gjeldende standarder i det omkringliggende samfunnet (DiMaggio \& Powell, 1983).

Et konkret eksempel på institusjonell påvirkning er hvordan kirken som en del av det norske samfunnet reguleres av lovgivningen. Likedanning med legitimitetsimplikasjoner kan illustreres ved at kirkelig virksomhet, som følge av å være koblet til statlig forvaltningsutvikling siden 1990-tallet, er underlagt målstyring. Dette perspektivet behandles i kapitlet om institusjonelle rammer som understreker kirkelig organisering og ledelse som kontekstuelt fenomen (kapittel 6). Frank Grimstad beskriver og drøfter hvordan institusjonelle rammer legger føringer for ledelse. Særlig vekt legges på regulerende rammer, et perspektiv som i stor grad har vært fraværende i ledelsesfaget. Flere eksempler illustrerer hvordan kirken er innleiret i stat og sivilsamfunn og dermed bidrar til det handlingsrommet ledere har. Kapitlet trekker veksler på den amerikanske organisasjonssosiologen Richard Scotts (2014) teoretiske perspektiver på 
institusjoner som regulerende, normative og kulturelt-kognitive, samt på mekanismer som bidrar til deres funksjon.

\section{Institusjonalisering}

Institusjoner er styrende strukturer og mønstre, som innbefatter verdier og normer for sosial atferd. Aktører og organisasjoner som handler i overenstemmelse med disse oppnår legitimitet og støtte i omgivelsene. Institusjoner har evne til å motstå endring, og historie har en betydelig vekt som stabiliserende og rutiniserende faktor (Scott, 2014). Mens det generelle begrepet institusjon sees som kulturelle regler som gir kollektiv mening og verdi til konkrete enheter og aktiviteter, betegner institusjonalisering prosesser der et gitt sett av enheter og aktivitetsmønstre blir normativt og kognitivt fastholdt og tatt for gitt.

Hvordan institusjonaliseringsprosesser konkret utspiller seg, utdypes i bokens tredje kapittel, der Stephen Sirris, Harald Askeland og Frank Grimstad drøfter tre spesifikke trender: Demokratisering refererer til fremveksten av ulike råd på forskjellige nivåer i kirken og hvordan lekfolket supplerer den tradisjonelle autoriteten hos presteskapet. Korporativisering betegner økt vekt på ledelse som organisatorisk mandat. Profesjonalisering omhandler spesialisering av arbeid og fremveksten av menighetsstabene. Dette kapitlet gir dermed en oversikt over sentrale utviklingstrekk ved Den norske kirke i nyere tid, samtidig som utviklingen rammes inn og drøftes i relasjon til sentrale institusjonelle endringer. Ved å beskrive fremveksten av organisatoriske, ledelsesmessige og profesjonsorienterte dimensjoner ved kirken, relateres kapitlet til at organisasjoner og institusjoner har en dynamisk historie der de formes gjennom arbeid og intensjoner som søkes realisert, men også gjennom historisk gitte institusjonelle mønstre. Forfatternes litteraturgjennomgang av utviklingstrekkene viser at de tre trendene er parallelle, men fremtrer tydeligere i noen perioder enn andre. Alle trekkene vektlegger økt interaksjon og samspill mellom aktørene.

Institusjonaliseringsteori er vag når det gjelder spesifisering av institusjonaliseringens drivkrefter, men prosessen betraktes i det store og hele som en naturlig utvikling. Dette ligner en organismes samspill med sine omgivelser. Men institusjonalisering vil også kunne fremstå som bevisste 
forsøk fra aktører på å nå sine mål. Samtidig kan det argumenteres for at aktørers strategiske atferd har en organisasjons grunnleggende verdier og normer som viktige rammebetingelser. En viktig side ved å forstå kirkens nåværende institusjonelle trekk, i en historisk sammenheng, har fått mindre vekt i nyere teoriutvikling. Tidlige institusjonelle studier vektla nærstudier av institusjonens historiske utvikling. Selznick (1949) argumenterte for at studiet av sammenhengen mellom verdier, sentrale organisasjonspolitiske prosesser og etablering av sosial og handlingsstruktur fordret organisasjonshistorisk innsikt. Historiens kontinuitet, eller varige trekk, utgjør en viktig side ved organisasjonsidentiteten, ikke minst for Den norske kirke. I kapittel 9 og 10, om identitet og lederrolle og om kirkevergens lederrolle, sees utviklingen av prostenes og kirkevergenes lederroller i et historisk perspektiv, nettopp for å se hvordan institusjonaliseringsprosessen også kan endre og befeste nye sider ved tradisjonelle rollemønstre.

\section{Hybridisering}

Videre avdekker et institusjonelt perspektiv at den empiriske kirkevirkeligheten inneholder en rekke mellomformer fremfor rendyrkede idealtyper. Hybridisering er derfor et begrep leseren vil møte flere steder. Begrepet er hentet fra biologien og refererer til krysningen av arter, men termen er importert til andre områder. Med hybridisering menes at ulike elementer, ideer eller logikker smeltes om og blir til noe nytt som er forskjellig fra det som var tidligere. Grunnleggende betegnes ulike mellomformer og kombinasjoner av elementer man vanligvis finner adskilt hver for seg. Slike nye kombinasjoner vil kunne fremme nytenkning og innovasjon (Sirris, 2019b).

Hybridisering på sektornivå henger sammen med endringer i kontekstuelle rammebetingelser eller glidende overgangene mellom ulike sfærer. Det betegner her organisasjoner som befinner seg i skjæringspunktet mellom ulike sektorer. Med hybridisering på organisasjonsnivå forstår vi at organisasjonen inneholder strukturelle, kulturelle og prosessuelle elementer fra ulike organisasjonstyper. Hybride organisasjoner innehar ofte flere og motstridende logikker, noe som kan kreve komplekse systemer og strukturer for å samordne disse logikkene (Sirris, 2019b). Det kan dermed oppstå spenninger ved hybridisering. Hybride organisasjonsformer 
vinner i stigende grad innpass. Hybridisering finnes også på individnivå, noe som uttrykkes gjennom endringer i identiteter og roller hos ledere, som illustrert i kapitlene 9 og 10.

I denne boken er hybridisering et nyttig begrep for å forstå hvordan gamle og nye idealer og utrykk har blandet seg i kirkelig organisering og ledelse og dermed utgjør et komplekst mangfold med ulike hybridiseringer. Dette poenget illustreres i kapittel 4, om kirke og menighet som organisasjon. Her argumenteres det for at ingen organisasjonsteori er nøytral, og at anvendelse av organisasjons- og ledelsesteori forutsetter en viss oversikt over grunnleggende faglige premisser. Kapitlets bidrag ligger i utvikling og anvendelse av et rammeverk som sorterer ulike teoritradisjoner ut fra kunnskapsteori og handlingsteori, med fire sentrale sett av teorier. Disse blir kort presentert, og tidligere forskning på religiøse organisasjoner tilordnes denne rammen ut fra deres teoretiske forankring. Slik bidrar kapitlet også til et riss av en faghistorisk utvikling. Avslutningsvis peker kapitlet på hvilke nyutviklinger som anses potensielt interessante i en videre utforsking av kirkelig organisering: multistandardorganisasjon, hybride organisasjoner og institusjonelt arbeid.

\section{Kirkelig organisering og ledelse i et praksisorientert perspektiv}

Vi drøfter i det følgende relevansen av bokens andre hovedperspektiv; en praksisorientert tilnærmingsmåte til kirkelig organisering og ledelse. En viktig bærebjelke i boken er at praksisorientering henger sammen med de tre begrepene kontekst, lederjobb og samhandling.

\section{Kontekst}

En praksisorientering favner ulike nettverk av samhandling mellom aktører. Dette er særlig nyttig gitt kirkens organisering med mange nivåer og interessenter. Videre gir praksisperspektivet på ledelse en deskriptiv fremfor normativ tilnærmingsmåte. Det samsvarer med vår posisjon, hvor vi i mindre grad tar stilling til hvordan ledelse bør utøves, men legger mer vekt på beskrivelser og forklaringer. Det forutsetter at vi har en empirisk interesse for å undersøke hvordan organisering og ledelse 
faktisk utspiller seg i kirkevirkeligheten. Det skjer ikke i et tomrom, men i spesifikke kontekster. Kontekst er noe som omgir og omleirer et objekt eller fenomen og er relevant for å forklare det (Scharfstein, 1989). Bevisstheten om kontekst har implikasjoner for forståelsen av organisasjon og ledelse. For det første vil kontekst kunne betegne de nære omgivelser for en organisasjon, med lokalsamfunn og dets kjennetegn samt andre organisatoriske enheter man samhandler med. Dernest vil det kunne angi kulturelle eller historiske kontekster (Mintzberg, 2009).

For ledere er organisasjonen konteksten og innrammingen for utøvelse av lederjobben, samtidig som ledere ved sitt ansvar og mandat kan skape kontekst for andres arbeid. Ledere kan bidra til å fortolke situasjon og formål for organisasjonens videre arbeid eller strategiske satsing (Ghoshal \& Bartlett, 1994). Kirkevergene illustrerer dette poenget i kapittel 10. Denne yrkeskategorien har en lang historie i lokalkirkelig forvaltning, særskilt hva gjelder økonomi, kirkebygg og kirkegård. Harald Askeland, Mildrid Fiske og Åslaug Styve Mjånes gir nye perspektiver ved å vise at kirkevergene historisk er blitt utnevnt og gitt legitimitet av ulike kirkelige myndigheter, biskop, konge, kommunestyret og fra 1997 kirkelig fellesråd som organ for soknet. Med kirkeloven av 1996 ble de tradisjonelle oppgavene, inkludert personalansvar, utvidet og lovfestet som daglig leder for lokal kirkelig virksomhet i kommunen. Utviklingen viser institusjonell nyorientering. Kapitlet bidrar til forståelse av hvordan kirkevergene siden innføringen av kirkeloven i 1997 har utviklet sin lederrolleforståelse fra administrative, personalrelaterte og oppgaverelaterte profiler og utviklet en bredere rolleprofil. I en lederundersøkelse (Askeland, 2016b) fremstår kirkevergene med en ny og markert utviklingsorientering. De profilerer en tydelig kirkelig identitet og gir uttrykk for å ivareta institusjonelt lederskap.

Også kapittel 7 bidrar til å posisjonere et kontekstuelt perspektiv. Her påpekes sentrale utviklingstrekk og tradisjoner innen ledelsesfaget, og innsiktene relateres til særtrekk ved kirken. Gjennom ledelsesfagets historie har ulike begreper hatt gjennomslag, som administrasjon, ledelse, lederskap og styring. Disse har vekslet mellom å være toneangivende. Kapitlet setter disse begrepene i relasjon til hverandre. Det argumenteres med at selv om begrepene kan skilles analytisk, er de innvevd i hverandre 
og vanskelige å skille i ledelsespraksis. Et poeng i kapitlet er verdien i å se ledelse som organisatorisk praksis fremfor i et mer tradisjonelt, individualistisk og rasjonalistisk perspektiv. Siste del av kapitlet utvikler sentrale punkter som gir perspektiver på kirkelig ledelse mer spesifikt, ved å trekke linjer fra arbeidsrett og teologi og vise hvordan det utkrystalliserer seg i en kirkekontekst.

Kontekst innebærer at praksiser er situert ikke bare i rom, men også i tid. Vårt rammeverk innebærer at kirkelig organisering både må forstås i et institusjonshistorisk perspektiv og samtidig i forhold til nåværende institusjonelle kontekst. Ikke minst er dette viktig fordi kirken kan sies å operere i skjæringspunktet mellom ulike institusjonelle kontekster, altså som en hybrid (Askeland et al., 2020). Kirken kan forstås både som trossamfunn i en religiøs sfære og som en forvaltningsorganisasjon preget av statskirkerelasjonen, men også som en lokalsamfunnsinstitusjon ved at kirkebygget og gravplassene har vært sentral ramme rundt presters arbeid i gudstjenester og livsriter. I kapittel 8 argumenterer Harald Askeland for at en kirkerelevant ledelsesforståelse bør integrere innsikt vunnet gjennom forskning omkring begrepene ledelse og lederskap. Slik bidrar kapitlet til å føre sammen et institusjonelt og verdibasert samt et praksisorientert perspektiv på ledelse. Basert på en drøfting av bidrag om ledelsesatferd og -praksis, konkretisert i utvikling av lederrolleprofiler over tid, bidrar kapitlet med utvikling av en ny firedelt ledelseskategori basert på empirisk forskning. Denne grunnleggende rollemodellen for ledelse integreres med verdiaspektet, slik det har vært utformet i institusjonelt lederskap. Historien gir tyngde samtidig som ledelse også må ivareta tidsriktige uttrykk for å ha legitimitet.

\section{Lederjobb}

Vårt andre utgangspunkt for en praksisorientering, er at ledelse for mange er en jobb med et organisatorisk gitt og forankret mandat. Kirken har gitt personer i oppdrag å fylle lederposisjoner. Ledelse innebærer et ansvar for flere enn seg selv, og for flere oppgaver enn man selv kan ivareta. Derfor inngår både relasjoner og oppgaver som sentrale dimensjoner i ledelsesutøvelsen. Videre må ledere både ha blikk for livet innenfor organisasjonen, men også for hva som skjer i omgivelsene. Vi forstår 
derfor ledelse som handling og som praksis (Mintzberg, 2009), og plasserer dermed boken i en særskilt praksisorientert ledelsesretning: managerial work behaviour-tradisjonen. Denne tematiserer både hva lederen gjør, og ikke minst, hvordan ledere er innvevd i samspill med andre. Et slikt praksisperspektiv retter oppmerksomheten mot situert interaksjon (Nicolini, 2012). Verden sees som prosessuell, og praksis er mønstre av samhandling. Disse kan inndeles gjennom handlinger, utsagn, relasjoner og ulike rammebetingelser (Kemmis, 2009).

Fremfor et entydig fokus på strukturer og ordninger, ser vi på hvordan dynamikken er mellom strukturer og aktører og hvordan de gjensidig påvirker hverandre. I et sosiologisk ordforråd tar denne boken høyde både for organisering som rammer, men også ledere som aktører. Dette anliggendet er hovedsaken i kapittel 9. Stephen Sirris og Harald Askeland gir en innføring i hvordan kirkeledelse er studert som ledelse i praksis i en norsk kontekst. Denne retningen gjør bruk av begrepene rolle og identitet. Forfatterne undersøker forholdet mellom rolle og identitet gjennom en analytisk kobling av empiriske studier av kirkeledere fra en periode på over tjue år. Kapitlet viser ulike rollemønstre blant kategorier av kirkeledere og hvordan mønstrene har utviklet seg. Et viktig funn er at kirkelige lederroller fylles med stadig mer arbeidsgiverrelatert og administrativt innhold. Det organisatoriske mandatet er blitt tydeliggjort, noe som har bidratt til å gjøre lederrollene mellom prester, proster og kirkeverger likere. Forfatterne drøfter også hvordan roller og identiteter hybridiserer og kan inneholde spenninger mellom faglige og ledelsesmessige orienteringer.

\section{Samhandling}

Et tredje viktig poeng i bokens teoretiske rammeverk som gjelder praksisorientering, og implisitt i det foregående, er at utviklingen i Den norske kirke har ført til mer interaksjon og samhandling mellom ulike nivåer og aktører. Utviklingen av Den norske kirke har gjort den til en arbeidsorganisasjon, noe som krever både organisering og ledelse. Arbeidsfellesskapet i menighetene har vokst. Det medfører en rekke utfordringer både når det gjelder organisering og ledelse. Interaksjonen krever administrasjon, styring og samhandling (Døving et al., 2016). Kirken er på 
mange måter en profesjonspreget virksomhet (Molander \& Terum, 2008). Profesjonsperspektivet tydeliggjør at det foregår mye faglig arbeid i kirken som må sees i sammenheng med fagledelse, hvor ledelse er direkte relevant for oppgaven og dermed ligger innbakt i det å utføre en oppgave. Det skyldes også en økt profesjonalisering og mer samhandling mellom ulike profesjoner og med frivillige. Profesjonsperspektivet utfylles av å se på kirkelig virksomhet som kunnskapsarbeid. Kunnskapsorganisasjoner kan forstås som organisasjoner der arbeidskraft og kunnskap er en avgjørende suksessfaktor. Tjenestene er komplekse og unike. Kunnskapsarbeidere er etterspurt for sin høye formelle kompetanse fremfor den fysiske arbeidskraften de representerer. De har oftest spisskompetanse, mer enn sine ledere, som gjør dem særlig velegnet for spesialiserte arbeidsoppgaver. Det er viktig for dem å ha utviklingsmuligheter og rom for å være kreative - noe som får implikasjoner for organisatoriske rammer og ledelsespraksis.

Men også arbeidsgiversiden er profesjonalisert i Den norske kirke. Det moderne arbeidslivet og gjensidig avhengighet kan også føre til konflikter. Kapittel 11 poengterer at konflikter er uunngåelige og naturlige samt følger av utstrakt demokratisering og individualisering. Kapitlet viser hvordan personalkonflikter har blitt forstått og håndtert i Den norske kirke siden 1980-tallet. Stephen Sirris og Frank Grimstad identifiserer tre beslektede begreper som har vært sentrale i dette arbeidet: konfliktforebygging, konfliktforståelse og konflikthåndtering. Disse er innhentet fra den allmenne litteraturen og brukt i kirkelig kontekst. Fra å være et implisitt tema og overlatt til de lokale partene, har konflikt blitt et viktig ansvar for kirkeledere, i tråd med arbeidsmiljøloven. Kapitlet reflekterer over hvordan konflikter gir utfordringer for kirkeledere.

\section{Konklusjon}

Dette kapitlet har tatt opp spørsmålet: Hvordan kan organisering og ledelse $i$ Den norske kirke forstås som verdibasert og praksisorientert? Bokens teoretiske rammeverk bæres av disse to hovedperspektivene, som begge er illustrert gjennom enkeltkapitlene om organisering og ledelse. Det er imidlertid ikke slik at vi skiller mellom at organisering er verdibasert 
og ledelse er praksisorientert. Som eksemplene viser, er dette snarere to dimensjoner ved både kirkelig organisering og ledelse. Sammen utgjør de et helhetlig rammeverk. Organisering er tuftet på verdier og legger til rette for ledelsespraksiser. Basert på den foregående drøftingen, oppsummerer vi bokens sentrale bidrag gjennom følgende fire punkter.

For det første bidrar boken gjennom rammeverket til et helhetsperspektiv på organisering og ledelse i Den norske kirke. En slik samlet fremstilling er ikke gjort tidligere. Siden kirkeloven ble innført i 1997 har kunnskapsutviklingen på området skutt fart. Boken trekker veksler og sammenstiller kunnskap som er presentert gjennom ulike studier i denne perioden. Helhet forutsetter mange deler, og boken tar opp et bredt spekter av temaer, noe bokens todeling er et utrykk for. Videre er ulike aktører studert med en hovedvekt på lokale kirkelige ledere som prester, proster og kirkeverger. Selv om menigheten og det lokalkirkelige nivåt får mest oppmerksomhet, belyses det ved hjelp av bredere kontekstuelle forhold som bidrar til å perspektivere og posisjonere praksis i en større sammenheng. Men helheten gjelder mer enn sammenstilling. Bokens anliggende er å vise at et institusjonelt verdibasert perspektiv står seg godt sammen med en praksisorientert tilnærmingsmåte. Disse to delene av bokens teoretiske rammeverk kompletterer hverandre. Dette kapitlet har begrunnet rammeverket og illustrert dets nytteverdi i møte med kirken som forskningsobjekt. Rammeverket tar både høyde for kirkens identitet og verdier som religiøst fellesskap, og for kirken som en organisasjon med mange praksiser i form av virksomhet og aktiviteter. Kapitlet har påpekt relevansen av å sammenholde begge perspektivene.

Bokens distinksjon, men ikke adskillelse, av organisering og ledelse understreker vårt andre hovedbidrag. Rammeverket integrerer både struktur og aktør, eller system og individ. Ut over å gi beskrivelser av aktørers praksiser, settes disse inn i en organisatorisk sammenheng. $\AA$ arbeide i en kirkelig organisasjon gir handlingsrom med både muligheter og begrensninger. Boken beskriver hvordan ulike typer institusjonelle rammer omgir praksiser og setter dem i relasjon til andre praksisnettverk. Denne boken understreker ledelse som en organisatorisk forankret funksjon fremfor individuelt lederskap. Dette ståstedet er rotfestet i empiriske data fremfor preskripsjon av hvordan kirkelig organisering og ledelse bør 
være. Videre relaterer vi ledelse både til demokratiske styringsorganer og til nødvendige administrative funksjoner for å ivareta organisasjonens oppdrag. Boken har dermed oppmerksomhet rettet mot sammenhengen mellom organisering og ledelse.

Vårt teoretiske rammeverk muliggjør for det tredje både en synkron og en diakron orientering. Som drøftingen viser, er utgangspunktet vårt omfattende endringer i Den norske kirke. Bevissthet om og sensitivitet for kontekst er derfor fremtredende i denne boken. Dette innebærer at den primært er opptatt av kirkelig organisering og ledelse slik disse fenomenene utfolder seg nå. Like fullt er det en tydelig diakron eller historisk interesse i boken. Den viser seg gjennom oppmerksomheten på å sette fenomenene på en tidslinje ved å beskrive utviklingstrekk. På en side er dette naturlig gitt kirkens lange tradisjon som viser både kontinuitet, men også gradvis utvikling og brudd. Boken tar derfor et utgangspunkt i kirkens autorative kilde, Bibelen, gjennom referanser til kirkens fremvekst som fellesskap og organisering, nemlig ekklesiologien. Dermed står boken både i en historisk forankring gjennom bevissthet om kirkens historiske utvikling, samtidig som den gjennom analyser og drøfting av kirkens nåværende fremtredelsesformer gir frempek.

For det fjerde bidrar bokens rammeverk til kunnskapsutvikling ut over å være en sammenstilling av eksisterende forskning. Et sentralt bidrag her, er hvordan et verdibasert institusjonelt perspektiv kombinert med et praksisorientert perspektiv bidrar til å forstå organisering og ledelse i Den norske kirke. Med dette utgangspunktet settes teoretiske modeller og begreper i dialog med kirkevirkeligheten. Begrepene gir redskaper å tenke med og vil kunne ha praktiske implikasjoner for kirkelig virksomhet så vel som utforming av organisering og ledelse. Boken gir en rekke drøftinger av forholdet mellom det allmenne og det spesifikt kontekstuelle hva gjelder organisering og ledelse. På dette punktet gir boken et viktig teoritilfang til religiøse organisasjoner. Et eksempel er utforskningen av mellomformer av det som ofte beskrives som dikotomier og motsetninger. Hybridisering muliggjør en mer nyansert tilnærmingsmåte til forståelsen av roller og identiteter. Et annet eksempel er utviklingen av en modell for institusjonell ledelse som ivaretar både etablerte rolletypologier, basert på ledelsespraksis, og samtidig gir rom for en verdibasert 
ledelse som er naturlig grunnet kirkens identitet. Organisasjons- og ledelsesfaget settes i dialog med empiri fra kirkefeltet og med ekklesiologien som er læren om hva kirken er. Her ligger et verdifullt tverrfaglig element som kan videreutvikles i årene som kommer.

Avslutningsvis kan vårt teoretiske rammeverk, et institusjonelt verdibasert og et praksisorientert perspektiv på organisering og ledelse, være relevant også for andre organisasjoner enn Den norske kirke. I en tid som setter stadig høyere krav til kvalitet på varer og tjenester, effektivitet og måloppnåelse, samarbeid og spesialisering, kreves mye av organisasjoner og ledere. Bokens anliggende er at bevissthet om verdier og identitet er en viktig ressurs for å kunne prioritere. En praksisorientering komplementerer dette gjennom vekt på lederhverdager og konkrete og håndfaste måter å realisere organisasjonens oppdrag i den aktuelle konteksten.

\section{Referanser}

Aadland, E. (1994). Ledelse i menigheten. Rapport fra et forsøks- og utviklingsprosjekt. Diakonhjemmets høgskolesenter.

Aadland, E. \& Askeland, H. (Red.). (2017). Verdibevisst ledelse. Cappelen Damm Akademisk.

Aarflot, A. (1990). La kirken vore kirke. Cappelen.

Askeland, H. (1998). Ledere og lederroller. Om ledelse og lederroller i den lokale kirke. Tapir.

Askeland, H. (2016a). Hverdagsledelse [Doktorgradsavhandling, Det teologiske Menighetsfakultet]. VID Open. http://hdl.handle.net/11250/2501771

Askeland, H. (2016b). Ledelse og lederes roller i Den norske kirke. Lederrolleundersøkelsen 2016 i et tyveårsperspektiv. Tidsskrift for Praktisk Teologi, 33(2), 5-19. https://journals.mf.no/tpt/article/view/5197

Askeland, H. (2020). Values - reviewing the construct and drawing implications for values work in organisation and leadership. I H. Askeland, G. Espedal, B. J. Løvaas \& S. Sirris (Red.), Understanding values work: Institutional perspectives in organizations and leadership (s. 15-34). Palgrave Macmillan. https://doi.org/ 10.1007/978-3-030-37748-9

Askeland, H., Espedal, G., Løvaas, B. J. \& Sirris, S. (2020). Understanding values work: Institutional perspectives in organizations and leadership. Palgrave Macmillan. https://doi.org/10.1007/978-3-030-37748-9

Askeland, H. \& Schmidt, U. (Red.). (2016). Church reform and leadership of change. Pickwick Publications. 
Botvar, P. K., Brottveit, Å., Hoel, N., Haakedal, E. \& Schmidt, U. (2015). Avsluttet reform eller fortsatt loering og utvikling? Trosopploering som arbeidsform $i$ menighetene. KIFO.

Botvar, P. K. \& Mosdøl, H. O. (2014). Gudstjenestereform og endringsorientering. Tidsskrift for Praktisk Teologi, 31(2), 48-6o. https://journals.mf.no/tpt/article/ view/5161

Carroll, J. W. (1991). As one with authority. Reflective leadership in ministry. John Knox Press.

Dietrich, S., Dokka, T. S. \& Hegstad, H. (Red.). (2011). Kirke nå! Den norske kirke som evangelisk-luthersk kirke. Tapir akademisk forlag.

DiMaggio, P. \& Powell, W. W. (1983). The iron cage revisited. Collective rationality and institutional isomorphism in organizational fields. American Sociological Review, 48(2), 147-16o. https://doi.org/10.1016/So742-3322(oo)17011-1

Døving, E., Elstad, B. \& Storvik, A. E. (Red.). (2016). Profesjon og ledelse. Fagbokforlaget.

Furseth, I. (2015). Religionens tilbakekomst i offentligheten? Religion, politikk, medier, stat og sivilsamfunn i Norge siden 1980-tallet. Universitetsforlaget.

Ghoshal, S. \& Bartlett, C. A. (1994). Linking organizational context and managerial action. The dimensions of quality of management. Strategic Management Journal, 15(S2), 91-112. https://doi.org/10.1002/smj.4250151007

Grimstad, F. \& Askeland, H. (1996). Kirkelig ledelse. En ressursbok om ledelse i den lokale kirke. KA Kirkens arbeidsgiverorganisasjon.

Hampel, C. E., Lawrence, T. B. \& Tracey, P. (2017). Institutional work: Taking stock and making it matter. I C. E. Hampel, T. B. Lawrence, P. Tracey, R. Greenwood \& C. Oliver (Red.), The Sage handbook of organizational institutionalism (s. 558-590). Sage.

Hegstad, H. (1996). Folkekirke og trosfellesskap. Et kirkesosiologisk og ekklesiologisk grunnproblem belyst gjennom en undersøkelse av tre norske lokalmenigheter. Tapir forlag.

Hegstad, H. (1999). Kirke i forandring. Fellesskap, tilhørighet og mangfold i Den norske kirke. Luther forlag.

Hegstad, H. (2009). Den virkelige kirke: Bidrag til ekklesiologien. Tapir akademisk forlag.

Hougsnæs, M. H., Askeland, H. \& Grimstad, F. (Red.). (2003). Ledelse i kirken.

KA Kirkens arbeidsgiverorganisasjon.

Huse, M. (1998). Prosten. Ansvar, arbeidssituation og ledelse. Tapir.

Huse, M. (Red.). (200o). Prest og ledelse. Verbum.

Jacobsen, D. I. \& Thorsvik, J. (2019). Hvordan organisasjoner fungerer. Fagbokforlaget. Jeavons, T. H. (2004). Religious and faith-based organizations: Do we know one when we see one? Nonprofit and Voluntary Sector Quarterly, 33(1), 140-145. https://doi.org/10.1177/0899764003257499 
Johansen, C. B. \& Waldorff, S. B. (2017). What are insitutional logics - and where is the perspective taking us? I G. Krücken, C. Mazza, R. E. Meyer \& P. Walgenbach (Red.), New themes in institutional analysis (s. 51-76). Edward Elgar Publishing.

Kemmis, S. (2009). Understanding professional practice: A synoptic framework.

I B. Green (Red.), Understanding and researching professional practice (s. 19-38). Brill Sense.

Mintzberg, H. (2009). Managing. Berrett-Koehler.

Mjelva, R. (1979a). Kirken som sosio-religiøst system. Kirke og kultur, 84(1), 105-116.

Mjelva, R. (1979b). Styring i kirken. Kirke og kultur, 84(4), 633-636.

Molander, A. \& Terum, L. I. (Red.). (2008). Profesjonsstudier. Universitetsforlaget.

Nicolini, D. (2012). Practice theory, work, and organization. An introduction. Oxford University Press.

Pratt, M. G. \& Ravasi, D. (Red.). (2016). The Oxford handbook of organizational identity. Oxford University Press.

Repstad, P. (2020). Religiøse trender i Norge. Universitetsforlaget.

Saxegaard, F. (2009). Presten som symboliserende, strategisk og samhandlende leder: En modell for sokneprestens lederskap i folkekirken. Halvårsskrift for Praktisk Teologi, 26(2), 17-28.

Scharfstein, B.-A. (1989). The dilemma of context. New York University Press.

Schmidt, U. (2016). Church reforms and public reforms. I H. Askeland \& U. Schmidt (Red.), Church reform and leadership of change (s. 38-55). Pickwick Publications.

Scott, W. R. (2014). Institutions and organizations. Ideas, interests and identity. Sage.

Selznick, P. (1949). TVA and the grass roots. A study in the sociology of formal organization. University of California Press.

Selznick, P. (1957). Leadership in administration: A sociological interpretation. Row Peterson.

Sirris, S. (2016). Arbeidsdager mellom profesjon, ledelse og organisasjon soknepresters tidsbruk og aktivitetsmønstre. Teologisk Tidsskrift, 4(1), 60-88. https://doi.org/10.18261/issn.1893-0271-2016-01-05

Sirris, S. (2019a). Coherent identities and roles? Hybrid professional managers' prioritizing of coexisting institutional logics in differing contexts. Scandinavian Journal of Management, 35(4).

Sirris, S. (2019b). Managers negotiating identities. Hybridizing professionalism and managerialism in faith-based health organizations and in religious organizations [Doktorgradsavhandling, VID vitenskapelige høgskole]. VID Open. http://hdl. handle.net/11250/2632293

Skjevesland, O. (1994). Huset av levende steiner. En teologi for menighetsoppbygging. Verbum.

Skjevesland, O. (1998). Morgendagens menighet. Ledelse og livsform. Verbum. 
Skjørshammer, M. \& Aadland, E. (1991). Ledelse i kirken - hva kan moderne ledelsesteori bidra med? Tidsskrift for Kirke, Religion og Samfunn, 4(1), 3-25.

Sporsheim, A. \& Sirris, S. (2018). Frie og villige? Ansatte som frivillighetsledere i Den norske kirke. Tidsskrift for Praktisk Teologi, 1, 57-71. https://journals.mf.no/tpt/ article/view/5236

Torry, M. (2017). Managing God's business. Religious and faith-based organizations and their management. Routledge.

Tracey, P., Phillips, N. \& Lounsbury, M. (Red.). (2014). Religion and organization theory. Emerald Group Publishing. https://doi.org/10.1108/So733-558X20140oooo 41003

Yukl, G. A. (2013). Leadership in organizations. Pearson. 

Del I

Kirkelig organisering 



\title{
Kirken som organisme og organisasjon. Ekklesiologiske og organisasjonsteoretiske perspektiver på kirken som felleskap
}

\section{Stephen Sirris}

VID vitenskapelige høgskole

\section{Harald Askeland}

VID vitenskapelige høgskole

\begin{abstract}
Due to the complexity of its functions, the church can be understood in various disciplines which offer different perspectives, concepts and metaphors. This chapter explores how theology and organizational sociology conceptualize the church as a collective. We aim at establishing a dialogue on the collective notion of the church as a religious organization using the concepts organism and organization as applied in the theological discipline of ecclesiology and utilizing insights from organization theory. Both hold that the church is a gathering of people coming together for religious purposes. Starting with a shared understanding of the collective, we present relevant insights from both domains. We analyze selected contributions in each tradition that enable an ongoing dialogue between them. The chapter argues that cross-disciplinary perspectives are beneficial to developing church organization.
\end{abstract}

Keywords: church, collective, ecclesiology, organism, organization, sociology

Sitering av denne artikkelen: Sirris, S. \& Askeland, H. (2021). Kirken som organisme og organisasjon. Ekklesiologiske og organisasjonsteoretiske perspektiver på kirken som felleskap. I S. Sirris \& H. Askeland (Red.), Kirkelig organisering og ledelse: Et verdibasert og praksisorientert perspektiv (Kap. 2, s. 35-57). Cappelen Damm Akademisk. https://doi.org/10.23865/noasp.129.ch2

Lisens: CC BY-NC-ND 4.0 


\section{Introduksjon}

Kirken kan forstås som et åndelig fellesskap av troende, men den kan også sees som en organisasjon. Disse ståstedene kan utelukke hverandre eller kombineres i ulike varianter. For eksempel kan Den norske kirke betraktes fra en rekke synsvinkler, avhengig av ståsted. Enkelte erfarer kirken eller menigheten som et kristent fellesskap av troende med et aktivt engasjement. For noen er kirken en arbeidsplass hvor man hever lønn for sin innsats. For andre igjen er kirken en sentral institusjon i samfunnet som bidrar til å markere høydepunkter i året og overganger i livet. Et grunnleggende spørsmål er om tro kan organiseres. Som vi skal se, er kirken en religiøs organisasjon som er grunnlagt på den kristne troen og har som formål å fremme denne. Ulike erfaringer og ståsteder retter søkelyset på forskjellige sider ved kirken og dens virksomhet. Gitt et slikt mangfold argumenterer vi i dette kapitlet for at det er nyttig å bruke flere faglige perspektiver for å forstå kirkens kompleksitet.

Kapitlet undersøker ulike forståelser av kirken som fellesskap. Derfor identifiserer vi begreper som griper dobbeltheten i religiøse fellesskap som fremtrer korporativt i samfunnet. Teologi og organisasjonssosiologi er fagdisipliner som aktivt har bearbeidet denne typen spørsmålsstillinger og begreper. Begge fagfeltene gir innspill til å forstå og belyse kirken som fellesskap eller kollektiv, og bruker sitt eget vokabular, modeller og metaforer. Kirken som kollektiv relaterer til hvilke teoretiske perspektiver og modeller som er legitime i forståelsen av kirken. I tillegg handler det om betydningen av de modeller vi anvender - og ikke minst deres styrke og svakhet for å utvide forståelsen av kirken. Vi argumenterer for at organisasjonsteori vil få en stadig sterkere aktualitet for forstålsen av kirken, særlig i endringstider. Samtidig ønsker vi å bygge noen broer mellom organisasjonsteoretiske begreper relatert til religiøse organisasjoner og ekklesiologiske forutsetninger, som i teologi faget representerer læren om kirken.

Kapitlet belyser teologiske og sosiologiske kollektivbegreper og kategorisering av religiøse organisasjoner. Formålet er å identifisere og sammenligne innsikter fra begge fagområdene. Vi polariserer dem ikke, men forutsetter at begge er nyttige. Problemstillingen vi søker å besvare, er: Hvordan forstår ekklesiologi og organisasjonsteori kirken som fellesskap? Vi beskriver først utvalgte ekklesiologiske perspektiver på fellesskap, særlig 
begrepene communio (delaktig fellesskap) og ekklesia (kirke/forsamling). Deretter presenterer vi noen organisasjonsteoretiske bidrag til forståelsen av religiøse organisasjoner. Organisasjonsteoretiske hovedperspektiver blir presentert i kapittel 4 i denne boken, og vi prioriterer derfor her ekklesiologiske modeller. Deretter sammenstilles begge fagtradisjoner i en overordnet drøfting av hvordan fellesskapet forstås som organisme og organisasjon.

\section{Synlige og usynlige fellesskap}

En organisasjon er abstraksjon av sosiale relasjoner og handler grunnleggende om interaksjon, samhørighet, verdifellesskap og praksiser. Organisasjon kan dermed fruktbart sammenlignes med begreper om andre sosiale relasjonssett eller arrangementer. En slik presentasjon er gjort av sosiologen Willy Martinussen (1984), der begrepet sosial organisasjon viser til en fortetting mellom relasjonene, gjerne en slags formalisering og strukturering av dem. Oftest følger en standardisering av aktuelle handlingsrepertoar i form av organisatorisk rollefordeling og rolleatferd. Så langt er mye observerbart. Men videre skjer det, ifølge Martinussen, en sterkere formålsorientering idet organisasjonen utvikler normer og verdier. Også andre organisasjonsforskere har understreket at organisasjoners kompleksitet gjør at alle sider ikke er direkte synlige. Den svenske organisasjonsforskeren Nils Brunsson (1991, s. 14) skriver:

Vi snakker om organisasjoner av ulike slag som om det var saker og ting man kan ta på. Som om det var organismer eller maskiner eller hus eller noe slikt. Men den ubehagelige sannheten er at ingen har noensinne sett en organisasjon. Det gjør at studiet av organisasjoner blir både vanskeligere og mer interessant. For at det skal bli noen organisasjoner å snakke om, så må vi konstruere dem selv. Det er de bildene av organisasjoner som vi har i hodene våre, vi diskuterer når vi drøfter organisasjoner.

Som Brunsson poengterer, er organisasjoner ikke fullt ut objektive eller sansbare størrelser. Mange organisasjoner vil kunne beskrive seg som verdibaserte. De fremmer immaterielle verdier og bygger relasjoner og fellesskap av immanent og, i tilfellet religiøse organisasjoner, transcendent 
karakter. I dette perspektivet ligner organisasjonsbegrepet på kirkebegrepet. Prinsipielt forstår mange kirken som et fellesskap ut over det man kan definere rent sosiologisk. Den fremstår likevel som en organisatorisk størrelse med ledelse, ansatte, arbeidsområder og tiltak. Til spørsmålet om hvilke kategorier som bidrar til å identifisere kirken som en organisasjon, avhenger svaret av fagtradisjon. Det kan også spørres om Den norske kirke er én eller mange organisasjoner.

Innenfor ekklesiologien har teologen Harald Hegstad (2009) påpekt det utfordrende ved å hevde at kirken er usynlig framfor synlig. Prinsipielt har ingen fullstendig kunnskap om hvor og hvem kirken er. I siste instans er dette unntatt empirisk observasjon og verifisering. Hegstad (2009) argumenterer for at kirken forstår seg som en organisme skapt av Gud ved Den hellige Ånd gjennom Ordet, samtidig som kirken som er organisasjon en sosialt gripbar størrelse som former sin historie i en kontinuerlig samfunnsmessig og kulturell brytningsprosess. Det handler altså om forestillinger og tro omkring disse fenomenene, og forblir et trosspørsmål. I likhet med andre sosiale organisasjoner, har kirkens oppdrag en tydelig fellesskapskarakter. Oppdraget kan forstås som en dobbel bevegelse; samling gjennom å bygge fellesskap i Jesu nærvær (Matt 18,20) og sendelse ved å utbre evangeliet (Matt 28, 18-20).

\section{Ekklesiologiske perspektiver på felleskap}

Det er flere endringer i kirke og samfunn som innbyr til fornyet drøfting av kirkelig organisering. Norge har de siste tiårene hatt en overgang fra en luthersk enhetskultur til et sekularisert og pluralistisk samfunn. Et normativt ståsted er at kirkelig organisering må ta utgangpunkt $\mathrm{i}$ kirkens oppdrag. I luthersk tradisjon legger kirkens identitet og kall føringer for hensiktsmessig organisasjonsform og praksis (Hauglin \& Hegstad, 2005, s. 27). I et historisk perspektiv er spørsmålet om tjenlig kirkeorganisering blitt besvart på mange ulike måter, uttrykt gjennom ulike kirkesamfunns organisering. Dette delkapitlet gir først en bibelsk og konfesjonell forankring til ekklesiologien. Deretter beskrives dens empiriske vending, før vi presenterer to tilnærmingsmåter til ekklesiologien, henholdsvis basert på begrepene communio og ekklesia. 


\section{En hellig, allmenn kirke}

Kirke og menighet er betegnelser for det kristne fellesskapet. Jesus kalte disipler til fellesskap med seg og hverandre. Evangeliet skaper tro på Kristus og bringer ham nær hvor Ordet lyder. Da konstitueres kirken, og menigheten oppstår. Uavhengig av nåværende utforming av kirkeordning, har kirkesamfunnene et felles utgangspunkt i Bibelens metaforer som beskriver det kristne kollektivet. Kirken som Kristi kropp (Rom 12 og 1 Kor 12) påpeker en identifikasjon mellom Kristus og kirken hvor de troende utgjør lemmer på legemet og har en organisk forbindelse. Kirken kalles også «Guds tempel» (2 Kor 6,14) og understreker at kirken er et fellesskap av mennesker fremfor å være en fysisk bygning. Teologen Karl Olav Sandnes (1994) påpeker at det Det nye testamentet bruker familie- og slektsterminologi for å si noe om relasjoner i det kristne fellesskapet.

I kirken har menigheten alltid utgjort den primære og viktigste konteksten for troende. Fellesskap utgjør også rammen for ledelse. I oldkirken fantes ulike mønstre og funksjoner for lederskap i menighetene, og disse var ofte parallelle til allmenne organiseringsformer i samtiden. Det er ikke mulig å lese et ensartet ledelsesmønster i menighetene ut fra Det nye testamente (Baasland, 1993; Schillebeeckx, 2014). Ledelsesformen i den nytestamentlige kirken, som bestod av en rekke ulike menigheter spredt utover et stort område, svarer til behovet for å holde sammen en relativt liten og oversiktlig sosial gruppe innenfor en kulturell kontekst som både religiøst og politisk var annerledes og til dels antagonistisk (Clarke, 200o). Menigheten ble holdt sammen av en sterk ideologi i form av tro og verdier, og ledelsesfunksjonene var konsentrert rundt forkynnelse, menighetssamling og omsorg for de fattige.

Det nye testamentet gir et alternativt ordfelt til styring, kontroll og herskermakt. Kirken tok i bruk samtidens begreper for ledende roller, for eksempel patron, presbyter og episkopos, men gav dem etter hvert sitt særegne preg (Collins, 1990). Diakonia, det greske ordet for tjeneste, ble et nøkkelbegrep med et annet preg enn datidens ledelsesspråk preget av asymmetri og hierarki. Lederskapet i menighetene utvikles i løpet av de første hundre år til et tydeligere mønster. Det nye testamente rommer både nådegavelister, som viser en karismatisk ledelse, og mer faste mønstre 
og tjenester i en gryende organisering i og av det kristne fellesskapet (Baasland, 1993).

Ledelse og organisering følger dermed av at kirken i sitt vesen er et fellesskapsfenomen - «et fellesskap av mennesker, samlet i Jesu navn, om Ordet og sakramentene» (Hegstad, 2009, s. 10). Videre er kirken «et konkret og erfarbart felleskap av mennesker som kvalifiseres som kirke gjennom sin relasjon til den treenige Gud» (Hegstad, 2009, s. 17). Ekklesia, de som er kalt, er den allmenne greske betegnelse på folkeforsamling. I Det nye testamentet henspiller begrepet på kahal, som er den gammeltestamentlige betegnelsen for Israel samlet for Guds ansikt (5 Mos 23,2). Begrepet kan referere til lokale fellesskap (Gal 1,2) i betydningen forsamling og menighet, og til kristne over hele jorden (Gal 1,13). Den apostoliske trosbekjennelsen beskriver kirken som «én, hellig, allmenn og apostolisk». Confessio Augustanas artikkel 7 lyder: «Men kirken er forsamlingen av de hellige (congregatio sanctorum), der evangeliet blir lært rent og sakramentene forvaltet rett.» Martin Luther skriver i De schmalkaldiske artikler: «For hva kirken er, det vet, Gud skje takk, et barn på sju år, nemlig de hellige troende og 'de sauene som hører sin hyrdes røst'» (Joh 10,3).

\section{Ekklesiologiens empiriske vending}

Gitt Bibelens og bekjennelsenes rike metaforer og kirkens kontinuerlige refleksjon om hva og hvem kirken er, argumenterer teologene Marit Halvorsen Hougsnæs (2004) og Harald Hegstad (2009) for at det kun finnes én kirke, men med synlige og usynlige dimensjoner. Posisjonen peker i retning en empirisk informert teologi, som ikke retter oppmerksomhet hva kirken burde være, men hva den faktisk er: den konkrete og erfarbare kirke. Dette antyder en empirisk vending også i teologien. I Norge har ekklesiologiske studier hatt tre hovednedslagsfelt, ifølge teologen Ulla Schmidt (2020). Disse er studier av lokalmenigheter, kirke-stat-relasjoner, og endring og reformer. Schmidt understreker at disse hovedtypene empiriske studier fanger opp kirken som sosial virkelighet på tre måter: interaksjon (mellom aktører og nivåer i kirkeorganisasjonen); institusjon (selvsagte og stabile strukturer med egenverdi); organisasjon (vektlegging av styring og sosiale systemer). 
Den amerikanske teologen Don Browning (1995) har utviklet en praksisteori-praksis-modell som poengterer vekselvirkninger mellom praksis og teori i teologien. Modellen står i motsetning til en deduktiv teologi, som ensidig informerer praksis. Inspirert av Browning inndeler Hegstad (2009, s. 11) ekklesiologien i fire faser. Fasene utelukker ikke hverandre, men gir ulike innfallsvinkler til kirkeforståelse og har også metodiske implikasjoner. For det første studerer deskriptiv ekklesiologi den faktiske kirkevirkelighet gjennom bruk av særskilte fagområder. Kirken undersøkes gjennom samfunnsvitenskapelige metoder, og fortolkes teologisk. Dette er en kombinasjon av et teologisk innenfra-perspektiv og et sosiologisk utenfraperspektiv. Et slikt ståsted fremheves av Hegstad (2009), som velger Matt 18,20 som utgangspunkt for ekklesiologien: «For hvor to eller tre er samlet i mitt navn, der er jeg midt iblant dem.» Mennesker møter hverandre, men troen innebærer også et møte med Gud. Historisk og geografisk kontekst spiller dermed en avgjørende rolle. Denne innfallsvinkelen innbyr til casestudier av kirken slik den fremtrer på en gitt tid og et gitt sted. Det leder til den andre fasen, hvor Hegstad påpeker en historisk ekklesiologi som tar for seg kirkens diakrone utviklingstrekk og uttrykksformer. Kirkehistorien viser både kontinuitet og brudd når det gjelder kirkens rolle, fremtredelsesformer og formidling. For det tredje finnes en systematisk ekklesiologi som gjelder lære og dogmatikk. Trosinnholdet og dets artikulering er noe ulik kirkesamfunnene imellom. Konfesjonell egenart kan avleses av skrifter som har bekjennelsesstatus, eller fravær av slike. For det fjerde kan kirken studeres i lys av en strategisk ekklesiologi, som gjelder veivalg, ønsket utvikling og en interesse for kirkevekst og menighetsutvikling. Her er ofte lokalmenigheten betont.

\section{Communio - fellesskap på tvers av tid og rom}

Den empiriske vendingen i teologien (jf. Browning, 1995; Hegstad, 2009) søker å forstå kirken i konteksten den befinner seg i. Posisjonen står i en viss spenning til å understreke kirkens universalitet og uforanderlighet. Denne nyorienteringen har også vært et viktig anliggende i et annet praktisk-teologisk område - økumeniske samtaler og samarbeid mellom kirkesamfunnene. Kirkenes forståelse av eget og andres særpreg har 
vokst, men samtidig har også forståelsen av det som er felles blitt styrket. I refleksjonen omkring kirkens karakter av fellesskap, er det greske og det latinske begrepet for fellesskap benyttet; koinonia eller communio. I økumenikken forstås kirken som et fellesskap som strekker seg over tid og rom, gjennom historien og over hele verden. Oikomene, et gresk ord for hele den bebodde verden, ble i oldkirken brukt for å betegne kristenheten. Det innbefatter både lokale, regionale og nasjonale kirkefellesskap. Altså preges kirken som fellesskap både av universalitet og partikularitet.

Communio har utgangspunkt i forståelsen av Gud som treenig. Teologisk har begrepet sine røtter i det indretrinitariske fellesskap. Her forstås det som enheten mellom Gud, Sønnen og Den hellige Ånd. Kirken gjenspeiler dette og er i dynamisk utfoldelse. I Korinterbrevene brukes koinonia både om relasjonene i treenigheten, og om menigheter imellom (1 Kor 1,9). Men fellesskapet har også en etisk side (Apg 2). Communio handler grunnleggende om delaktighet (1 Kor 10,16; 1 Joh 1,3-6) og understreker hvordan individet inngår i en større sammenheng. På et overordnet plan inngår menigheter og konfesjoner i en større helhet. Ordparet communio og koinonia har også nedslag i den apostoliske trosbekjennelsen; communio sanctorum; de helliges samfunn. Med henvisningen til mennesker som kommer sammen i Jesu navn, betones fellesskapsaspektet i kirkeforståelsen. Kirken er et uoverskuelig fellesskap - men bærer visse organisatoriske kjennetegn og idealer som lar seg iaktta i sosiologisk forstand.

\section{Folkekirke og trosfellesskap}

Dåpen som sakrament setter den enkelte inn i en ny relasjon ikke bare til Gud, men også til andre mennesker. I dette fellesskapet deler menneskene samme vilkår i relasjonen til Gud. Dåpen er i luthersk kontekst eneste medlemskriterium i kirkens felleskap, uavhengig om graden av deltakelse (Dietrich, 2011). Den norske kirke har i $202069 \%$ av befolkningen som medlemmer, men et lite mindretall av disse deltar regelmessig i gudstjenester og oppgir å tro på Gud. Det gudstjenestefeirende fellesskapet faller vel å merke ikke alltid sammen med soknet og antallet døpte medlemmer. Hegstad (1996, s. 411) argumenterer derfor for et differensiert 
kirkebegrep. Distinksjonen mellom folkekirke og trosfellesskap har vært en viktig forståelsesramme i Den norske kirke (Hegstad, 2009, s. 99). På den ene siden utgjør folkekirken rekrutteringsgrunnlaget for trosfellesskapet. På den andre siden sikrer trosfellesskapet folkekirken med kompetanse, innsats og fordypning. Denne differensieringen antyder også at kirkens vekt på fellesskap brynes mot tidens individualisering (Repstad, 2020), der færre forplikter seg i et fellesskap. Dette kalles vikarierende religion: «religion performed by an active minority but on behalf of a much larger number, who (implicitly at least) not only understand, but, quite clearly, approve of what the minority is doing» (Davie, 2007, s. 88). Kirkereformer som gudstjenestereform og trosopplæringsreform har som intensjon å styrke felleskapet med Gud og mennesker og gjøre kristen praksis meningsfull for flere. Når folkekirkenes oppslutning faller og færre døpes, utfordrer dette definisjonen av kirkefellesskapet.

\section{Ekklesia - et stedbundet fellesskap}

Som communio-ekklesiologien understreker, er kirken et fellesskap på tvers av tid og rom. Samtidig er kirken stedbundet og manifestert. I det følgende skisserer vi en ekklesiologi som vektlegger ekklesia som et geografisk begrep. Dette er ikke egentlig et nytt teologisk innsteg, men en beskrivelse av Den norske kirkes egenart som geografisk basert. Dette har vært sentralt for Den norske kirkes inndeling i sokn, bispedømmer og en nasjonal og landsdekkende norsk kirke. Inndelingen går tilbake til kristningen av landet i middelalderen. Tradisjonelt er begrepet menighet i Den norske kirke ganske entydig forstått territorielt. Den svenske teologen Sven Anders Thidevall (2005, s. 162) understreker at territorialmenigheten ble måten å organisere kirkelig virksomhet på. Hensikten var at gudstjenester kunne holdes av prester i kirkebygg. Menighet består av menneskene som bor innenfor menighetens geografiske område. Dette omtales kirkerettslig som sokn, og sammenfaller med menighet. I den kirkelige lovgivningen som gjaldt fram til 1996 kunne et sokn ha flere menigheter, knyttet til ett eller flere kapeller. Også disse var imidlertid geografisk avgrenset, såkalte kapelldistrikter (Hauglin \& Hegstad, 2005, s. 28). 
Et sokn inneholder i juridisk forstand kun én menighet. I praksis kan soknet bestå av flere menigheter teologisk og sosiologisk, eksempelvis dersom det er flere gudstjenestefellesskap i soknet. Et fellesskap trenger ikke formell juridisk status som menighet for å fungere i betydningen gudstjenestefeirende fellesskap. Denne teologiske forståelsen har bekjennelseskarakter med bakgrunn i Confessio Augustana artikkel 7: «Men kirken er forsamlingen av de hellige der evangeliet blir lært rent og sakramentene forvaltet rett.» Sett i lys av Matt 18,20 blir kirken et konkret fellesskap preget av Jesu nærvær. Gudstjenestefellesskapet og menigheten/ soknet var opprinnelig sammenfallende, men sekularisering og demografi har endret graden av samsvar. Opprinnelig var sammenhengen mellom organisasjon og gudstjenestefelleskap grunnleggende, men det har skjedd en oppløsning av forholdet mellom bosted og fellesskap. Ikke alle som bor innenfor soknegrensene er medlemmer, og de som er medlemmer, går ikke nødvendigvis i sin lokale kirke. De bor på ett sted, arbeider et annet og har gjerne fritidsbolig et tredje. Mange beholder et nært forhold til kirken hvor de vokste opp. Gudstjenestefellesskapet blir ofte en løst sammensatt gruppe som samles omkring Ordet og sakramentene. Eksempelvis er Svenska kyrkans ekklesiologiske minste minimum, kriterier for en menighet i Svenska kyrkan, et gudstjenestefeirende fellesskap, en kirke, en prest og et styre eller menighetsråd (Thidevall, 2005, s. 173).

\section{Kirke som organisasjon og nettverk}

Det kan være nyttig å skjelne mellom menighet som nettverk og organisasjon, selv om det er en viss gjensidig avhengighet. Organisasjon betegner her ressurser, systemer og beslutninger, mens nettverk er løsere bånd, relasjoner og bekjentskaper. Nettverket trenger støtte fra organisasjonens langsiktighet og helhet. Studerer man utviklingen av kirken, argumenterer Thidevall (2005, s. 179) med at organisasjonen har vokst, mens gudstjenestefellesskapet har minket. Vektlegger man fellesskapet som organisasjon, blir territorialmenigheten et naturlig utgangspunkt. Hegstad viser også (2009, s. 98) at kirken framstår som en rekke felleskap med varierende preg av fast organisering eller løsere nettverksbånd, eksempelvis ulike typer menighetsfellesskap og foreninger. Han drøfter også hva som kvalifiserer til å være menighet, og konstaterer hybride former: 
Spørsmål om hva som er menighet, grupper innen menigheten og andre former for fellesskap og nettverk, lar seg i mange tilfeller likevel ikke besvare eksakt. I mange tilfeller vil forholdet mellom smågrupper, menighet, nettverk på tvers av menigheter gli over i hverandre uten at det er klart hvor det ene slutter og det andre begynner. (Hegstad, 2009, s. 54)

Individualisering og demografiske endringer gjør begrepet nettverk sentralt. Den engelske teologen Pete Ward tar dette opp i boken Liquid church (2002). Boken bygger på Baumanns klassiker Liquid modernity (200o), som bruker metaforen liquid - væske. Å flyte er en egenskap ved væsker og gasser som kan forandre form. Nettverk er uformelle, flytende og bevegelige. Ward kontrasterer to idealtyper, analytiske begreper, som han appliserer på kirken: solid church og liquid church. Solid church forstår kirken som en samling av mennesker på ett sted til en bestemt tid; en menighet (2002, s. 2). Det er vekt på strukturer, institusjoner, møter, systemer og bygninger. Dette tilsvarer territorialmenigheten med vekt på forsamling og gudstjenestedeltakelse. Liquid church utfordrer derimot tanken på ett sentrum i form av en felles samling av de troende. I stedet er det en rekke ulike tilknytningspunkter hvor relasjoner blir viktig. Ward (2002, s. 15) argumenterer for at kirken må være i dialog med kulturen og være relevant for samtidens mennesker:

To be a liquid church means that we are able to combine with water to become fluid, changeable, flexible, and so on. [...] Only by locating church within culture can we find way to develop a distinctive Christian expression within the culture.

Kirken er med andre ord ulike fellesskap av mange større fellesskap. Liquid church forstår dermed det kristne fellesskapet som et nettverk eller en vev. Fellesskap er i denne forståelsen lite organisert, men vokser organisk frem i relasjoner og nettverk.

\section{Organisasjonssosiologiske perspektiver på religiøse organisasjoner}

Denne andre hoveddelen av kapitlet tematiserer hvordan organisasjonsforskere har studert religiøse organisasjoner. Ifølge de britiske sivilsamfunnsforskerne Colin Rochester og Malcolm Torry er menigheter 
prototypiske religiøse organisasjoner. De definerer menighet som «en gruppe mennesker som samles til gudstjeneste» og en religiøs organisasjon som «en mer eller mindre strukturert forsamling som møtes regelmessig for gudstjeneste» (Rochester \& Torry, 2010, s. 115). Kristen gudstjeneste er i en luthersk kontekst en samling for å forkynne evangeliet og feire nattverd. Også organisasjonsforskerne Robert Hinings og Mia Raynard (2014) vektlegger at religiøse organisasjoner grunnleggende sett er anerkjente, stabile samlinger for religiøse hensikter og formål, kjennetegnet av den teologiske basen som gir verdier og mening i sentrum, presteskapets rolle som formidlere av religion, og frivillighet. Religiøse organisasjoner er basert på teologisk tro og samles for teologiske formål. Samtidig er slike organisasjoner plassert i en videre sosial kontekst. Kirken er dermed unik, men også lik andre organisasjoner.

\section{Utvikling og utbredelse}

Den engelske religionssosiologen James Beckford (1985) poengterer at grensene mellom det hellige og det sekulære ikke er stabile. Det kan medføre utvisking av særtrekkene ved religiøse organisasjoner. Han påpeker også at religiøse organisasjoner blir stadig mer preget av to trekk. Byråkratisering gjelder fordeling av arbeidsoppgaver, hierarki, regler og retningslinjer. Dette skyldes styrket administrasjon, desentralisering og økende institusjonalisering av tro og praksiser. Profesjonalisering er høyere utdannelsesnivå og faglig praksis. Ifølge den kanadiske organisasjonsforskeren Henry Mintzberg (1979) er det en generell utvikling fra enkle strukturer med sterke karismatiske elementer til mer komplekse strukturer i byråkratiet. I den vestlige kristenheten er religion i høy grad formalisert og rutinisert nettopp ved at religiøse organisasjoner er så sentrale.

Et annet viktig utviklingstrekk er utbredelsen av organisasjonsbegrepet. Ulike kollektiver i samfunnet forstås i økende grad som organisasjoner. Dette henger sammen med standardisering og at organisasjoner blir mer like hverandre. Utviklingen utgjør en de-kontekstualisering, hvor unike trekk er nedtonet til fordel for fellestrekk. Gamle og tradisjonelle institusjoner bruker nå maler for organisasjoner (Bromley \& Meyer, 2017; 
Meyer \& Bromley, 2013). Den amerikanske ledelsesforsker Peter Drucker (1998, s. 2) skriver at $10 \%$ av lederjobben er kontekstspesifikk, mens $90 \%$ er generisk og uavhengig av sektor: «This $10 \%$ is determined by the organization's specific mission, its specific culture, its specific history and its specific vocabulary.» Kirkeledelse har noe spesifikt ved seg, selv om mye er likt uavhengig av sektor. Dette beskriver sosiologen og teologen Jackson Carroll (1991, s. 97) som å sikre identiteten til det kristne fellesskapet i omgivelser som kontinuerlig endrer seg. Han henviser til Philip Selznicks (1957) tre grunnfunksjoner hos ledere: 1) klargjøre organisasjonens oppdrag; 2) virkeliggjøre formålet i liv og virksomhet; 3 ) bidra til at organisasjonen og medlemmene fastholder verdiene.

\section{Særtrekk ved religiøse organisasjoner}

Den engelske religionsforskeren Margaret Harris (1995) supplerer Beckfords (1985) særtrekk ved kirkelig organisering. I religiøse organisasjoner blir struktur og kultur mål i seg selv. Det kan hindre innovasjon og utvikling, siden det blir viktig å ivareta og hegne om innarbeidede og etablerte arbeidsmåter. Kirken har mange interessegrupper eller koalisjoner med ulike mål. Kirken tilbyr stor bredde i tjenester og skal ekspandere gjennom at nye medlemmer legges til gjennom dåp, opplæring og misjon. Universalismen legger kontinuerlig press på medlemsøkning, og medfører at kirken skal favne alle og tilby noe relevant til alle aldersgrupper. Dessuten trekker kirken veksler både på ansatte og frivillige medarbeidere i stor skala. Ofte er kirkelig virksomhet avhengig av frivillige. Det kan også være spenninger mellom ansatte og lekmedlemmer. Dette innebærer desentralisering og flernivåorganisering; nasjonalt, regionalt og lokalt. Sterkt engasjement og samling om verdier og normer viser tilknytning og identifikasjon med kirken gjennom tilslutning til trosgrunnlaget (Sirris, 2017). Dette får betydning i beslutningsprosesser, og har historisk sett forlenet presteskapet med autoritet. Det gir andre autoritetsstrukturer enn de man finner i sekulære organisasjoner.

I likhet med organisasjonsfaget, har samfunnsvitenskapelige metoder en sentral rolle i den delen av sosiologien som befatter seg med religion. Fellesskap forstås som samhandling og mellommenneskelige relasjoner. 
Rutinisering og formalisering, vesentlige sider ved enhver organisasjon, er en klar fellesnevner for ekklesiologi og organisasjon, særlig vestlige kirkelige organisasjoner. Den amerikanske sosiologen Ross P. Scherer (1980, s. 15) påpeker at religiøse organisasjoner, på grunn av sin frivillighetskarakter, har en tendens til å være mer desentraliserte enn kommersielle og offentlige organisasjoner. Samtidig er de skjøre, ved at de holdes sammen mer av følelser, holdninger og forpliktelse enn av struktur og organisatorisk apparat.

Bidragene som hittil er omtalt, opererer med ulike kollektivbegreper når kirke og menighet beskrives som organisasjoner. For eksempel vil Beckfords (1985) system- og institusjonsperspektiv vektlegge et strukturelt nivå med felles organisatoriske mønstre og et sterkt verdifundament. Harris (1995) omtaler menighetene i et assosiasjonsperspektiv, der aktører inngår i lokale verdibaserte fellesskap. Scherer (1980), med sin vekt på holdninger og følelser, legger seg nær et aktørperspektiv, men ser også de lokale enhetene i rammen av en kirkelig struktur. En annen viktig dimensjon som indirekte kan leses ut av disse bidragene, er grad av rasjonalitet eller formalisering. Organisasjonssosiologien opererer ofte med skillet mellom rasjonelle og naturlige kollektiver for å fange sosiale og uformelle trekk ved formelle organisasjoner (Lysgaard, 1967; Scott, 1987, s. 22). Selv om disse dimensjonene framstår som implisitte i de nevnte arbeidene, vil de passe inn i etablerte kategoriseringer av organisasjonsteorier (Scott, 1987).

\section{Kirken som organisme og organisasjon}

Så langt har vi undersøkt ekklesiologiens og organisasjonssosiologiens forståelse av kirken som fellesskap. Videre drøfter vi først likheter og forskjeller i fagområdenes fellesskapsbegrep, og deretter forholdet mellom ekklesiologi og organisasjonsteori.

\section{Likheter og forskjeller i fagenes fellesskapsbegreper}

For å komme til rette med begge fagområder som studerer kirken som fellesskap, ønsker vi å nyansere to aspekter ved fellesskap. Distinksjonen 
mellom organisasjon og organisme brukes teoretisk for å skille mellom to grunnleggende perspektiver i studiet av organisasjoner. De kan enten sees som formelle strukturer med eksplisitte mål og strukturer for oppgaveløsning, eller som naturlige organismer med interne, aktørdrevne og uformelle behov ivaretatt gjennom sosiale prosesser (Scott, 2014). I kirkelig kontekst har begrepsparet organisasjon og organisme vært anvendt om ytre strukturer på den ene siden og det indre og åndelige, eventuelt kultur, på den andre (Skjevesland, 1998). Organismebegrepet er i utgangspunktet anvendt i biologien, men er importert av organisasjonsfaget og ekklesiologien. Organisme betegner primært et tett samspill mellom mange enheter. Organisere betyr å utstyre med organer. Helhet og sammenheng er ikke forbeholdt organisme eller organisasjon alene. Alle organisasjoner er organismer i betydningen at de oppholder seg i et miljø og preges av sine omgivelser.

Organisme og organisk er positivt ladede begreper som kan representere en motpol mot det antatt mer statiske organisasjonsbegrepet. Begrepsparet fremstilles ofte som en dikotomi, altså en motsetning som utelukker et tredje alternativ. Dette ønsker vi å nyansere. Innenfor organisasjonsfaget brukes gjerne organisme for å betegne uformelle sosiale strukturer og kultur, mens organisasjon refererer til formaliserte atferdsstrukturer. Disse er ikke gjensidig utelukkende, men forutsetter snarere hverandre. Mens det sosiale miljø skaper kultur, normer og verdier gjennom relasjoner, er struktur mer knyttet til rutiner, systemer og hierarki. Kultur kan sammenlignes med muskler som får det strukturelle skjelettet til å bevege seg. Samtidig trengs strukturen for å opprettholde kulturen og gi den form og retning.

Noen skjelner mellom struktur og administrasjon på den ene siden, og kjernevirksomhet på den andre siden. Denne forståelsen er utbredt hos profesjonene grunnet spesialisering innenfor et gitt fagfelt. Struktur innbefatter formelle sider som arbeidsgiveransvar, forvaltning, økonomi og rammer for virksomheten. Kjernevirksomheten er sentrale oppgaver og innhold og utøvelse av fag. Men profesjonsutøvere arbeider i organisasjoner, og det er økt vekt på å skape samsvar mellom organisasjonens og ansattes mål og verdier. Så langt ser vi at dikotomier er nyttige som analytisk utgangspunkt, men i praksis kan ikke distinksjonene skarpt 
opprettholdes. Struktur og kultur, organisasjon og organisme, har et symbiotisk forhold. Symbiose henviser til fysisk tette forbindelser der den ene arten lever i eller på den andre, og innebærer synergier. Metaforer er språklige virkemidler. Et for vanntett skille hindrer utviklingen av en felles terminologi mellom de to fagområdene. Fagene har hvert sitt «språk», uttrykt gjennom konseptualisering, nye modeller og begreper, men idéinnholdet kan også være beslektet. Både ekklesiologi og organisasjonsfaget har som mål å være holistisk og evner å sammenfatte grunnleggende innsikter ved menigheten.

\section{Rasjonelt og naturlig perspektiv}

Distinksjonen mellom rasjonelle og naturlige perspektiver på organisasjoner belyser skillet mellom organisasjon og organisme (Scott, 2014). Vi kan forstå organisasjoner i et rasjonelt perspektiv, med vekt på formelle trekk og strukturer, der organisasjonen ses som et instrument for måloppnåelse. Suksesskriteriet blir hvorvidt organisasjonen har oppnådd planlagte mål i form av produkter eller tjenester. For å sikre at organisasjonen blir et mest mulig velfungerende redskap, tillegges ledere stor betydning. Sammenhengen mellom årsak og virkning blir viktig. Ledere skal redusere avstanden mellom ønsket tilstand, uttrykt gjennom mål, verdier og visjoner, og virkeligheten. I et rasjonelt perspektiv vektlegges gjerne strukturer, hierarki og kontroll for å gjøre organisasjonen styringsdyktig som et verktøy i lederens hender. Gitt den sterke målorienteringen, bygger organisasjonen for fremtiden og gir rom for vurderinger av nytte og konsekvenser.

Vi kan også anlegge et naturlig perspektiv på organisasjoner (Scott, 2014). Perspektivet er kulturelt og fortolkende med vekt på kultur og prosesser. I kulturen finnes normer, verdier og antakelser om hva som er passende og riktig. Slike forventninger harmonerer ikke allid med nyttevurderinger. Organisasjoner forstås som situerte i en særskilt historisk kontekst, der det unike vektlegges som sterk organisasjonsidentitet. Varige, distinkte og sentrale trekk kan gjøre endringer krevende. Verdier lar seg ikke uten videre bytte ut, noe som indikerer en motstand mot endring. Et naturlig perspektiv på ledelse er styringspessimistisk: Ledere har begrenset handlingsrom og påvirkningskraft, siden organisasjonen, 
gitt dens sterke kultur, kan sies å leve sitt eget liv. Dette samsvarer med en forståelse av organisasjonen som en organisme som utvikler over tid i samspill med indre prosesser og ytre omgivelser (Scott, 2014). Oppsummert er det slik at både et rasjonelt og et naturlig perspektiv kan vektlegge struktur eller aktør, slik det fremgår av tabell 1.

Tabell 1. Organisasjonsteoretiske perspektiver

\begin{tabular}{lll}
\hline & Rasjonelt & Naturlig \\
\hline Struktur & System & Institusjon \\
Aktør & Organisasjon & Organisme \\
\hline
\end{tabular}

Om en sammenholder tabell 1 med tilsvarende (Tabell 2) i kapittel 4 om organisasjonsteori i denne boken, finnes flere likhetstrekk. Både ekklesiologien og organisasjonsteorien synes å operere med kollektivbegreper som dels bygger på systemperspektiv og dels på aktørperspektiv. Kirken som institusjon, både i tradisjonell katolsk og i luthersk statskirkeversjon, er et hierarkisk system kontrastert av communio-perspektivet eller av de frivillige organisasjonene som vokste fram og dannet grunnlag for trosfellesskapet. Med selvstendiggjøringen av Den norske kirke fra staten, ser vi at denne distinksjonen igjen blir viktigere. Gjennom Den norske kirkes fristilling fra staten i ny trossamfunnslov, vil Kirkemøtet fremstå som det øverste representative organ for kirken. Slik oppstår behovet for avklaring mellom det nasjonale demokratiske organ i forhold til de lokale menighetene og deres valgte organer. Organisasjonsteoriens systemperspektiv er en kontrast til det aktørbaserte assosiasjonsperspektivet. Organisme og organisasjon forutsetter og utfyller hverandre framfor å gjensidig utelukke hverandre. Begrepene henger sammen og fremhever ulike sider ved samme fenomen. De er brukt på menneskelige fellesskap. Med dette som utgangspunkt, skal vi nå se nærmere på hvordan to fagtradisjoner belyser kirken som kollektiv med både organiske og organisatoriske trekk.

\section{Forholdet mellom fagene}

Perspektiver fra ekklesiologi og sosiologi kan gi komplementære analyser til et mer helhetlig bilde av organisasjonsforståelse. Begge fagområder har grenser, både for kompetanse, naturlig erkjennelsesområde og 
erkjennelsespotensial. Å fokusere på utfordringer ved bruk av organisasjonsfag i forståelsen av kirken, synliggjør at heller ikke dette faget er nøytralt. Det er ikke likegyldig hvilke bilder, modeller eller perspektiver vi bruker for å beskrive kirken og menigheten.

Et bidrag med primær basis i sosiologi, eller nærmere bestemt organisasjonssosiologi og -teori, står også i et forhold til teologi som det faget der en tradisjonelt har analysert og drøftet kirke og menighet. Disse faglige tilnærmingene har hatt et anstrengt forhold (Askeland, 1998, s. 19f). Teologi har vært sett som normativt; organisasjonsfaget som mer deskriptivt, basert på empiriske studier. Dette forholdet har utviklet seg, blant annet ved at teologien i større grad trekker veksler på empiriske studier. Organisasjonsfaget vil også ha innslag av implisitt normativitet, der «verdirelaterte premisser» angir alternative handlingsvalg eller vurderingskriterier (Furseth \& Repstad, 2003, s. 21-22). Religionssosiologene Inger Furseth og Pål Repstad fremhever at også tradisjonelt normative vitenskaper som jus og teologi har normer for vitenskapelig metode og publisering. For vår del har det ikke vært hensiktsmessig å karakterisere noen av disse fagene her, men peke på at de med hvert sitt utgangspunkt behandler sosiale kollektiver med begreper og perspektiver som kan være utfyllende eller kontrasterende.

Tilsvarende vil det være mulig å se ulik ekklesiologisk vektlegging i kollektivbegrepene. Vi har her påpekt at kirkelige aktørers organisasjonsforståelse, muligens som følge av de bildene eller metaforene som anvendes i teologiske analyser, trekker i retning av organiske begreper og organiske modeller. Oppmerksomheten rettes mot det lokale gudstjenestefeirende fellesskapet, jf. communio-begrepet. Organisasjonsfaglig representerer dette et naturlig syn på organisasjoner (Scott, 2014).

Samtidig har de europeiske majoritets- og statskirkene hatt en organisering, med tilhørende teologisk refleksjon, som også gjennom ekklesia-begrepet har fremmet mer strukturelt orienterte kirkeforståelser. En episkopal tradisjon vektlegger hierarkiet og lokale menigheter som grunnenheter av kirken. Tilsvarende viser utviklingen i mange lutherske kirker, med etablering av synoder eller kirkekonferanser, strukturelle trekk. Sammen med en synodal struktur vil det ofte etableres nasjonale kirkelige sekretariater til å forberede saker og iverksette vedtak på vegne av synoden. 
Noe forenklet vil vi hevde at det er to grunnleggende grøfter å gå i dersom organisasjonsfaget og dets begrepsbruk skal anvendes i analyse og utforming av kirkelig organisering. Den ene er å anta at kirken er blitt og kun sees som organisasjon. Da vil en ha forvekslet modellene med det de skal si noe om. Det andre er å anvende begreper fra faget upresist - det vanskeliggjør en nødvendig debatt om kirkelig organisering. En insistering på at ekklesiologiske modeller kan danne et entydig grunnlag for organisering, møter utfordringer. Etter vår vurdering gir communio- og ekklesia-teologien normative idealer og fordringer til kirkelig identitet. Disse er viktige ressurser og premissgrunnlag i en organiseringsdebatt. Tidligere ble det gjerne hevdet at det var et skille mellom kirkens sosiale form og den åndelige virkelighet - «et åndens samfunn» (Skjevesland, 1998). Denne distinksjonen er, som vi har sett, vanskelig å opprettholde (Hegstad, 2009; Hougsnæs, 2004). Den empiriske vendingen innenfor praktisk teologi gjør et slikt skille problematisk.

Et viktig anliggende i dette kapitlet å styrke forståelsen av kirken i et organisasjonssosiologisk perspektiv, kompatibelt og i dialog med empirisk basert ekklesiologi. Det har tidligere vært hevdet at organisasjonsteori kan gi et selvstendig bidrag til analyse av kirke og menighet i deres sosiale framtredelsesform. Den amerikanske institusjonsteoretikeren, Paul DiMaggio (1998, s. 7) gir følgende begrunnelse:

because much religious activity is institutionalized and carried out through formal organizations (for example churches, religiously affiliated charities, religious presses and broadcasters), students of religion may have something to learn from the experience of their colleagues in the organizations field.

Samtidig har sosiologien og teologien ulike tilnærmingsmåter til det samme forskningsområdet. Teologisk kan «kirke og menighet» og «verden og samfunnet» omtales som atskilte, motstridige størrelser. Sosiologisk forholder man seg til samfunn, kirke og menighet som del av dette. Dessuten, som en følge av det forrige, vil en teologisk kunne tale om kirken som subjekt og studere og forholde seg agerende til samfunnet fra en autonom posisjon. Sosiologien vil her nødvendigvis måtte forholde seg til både kirke og samfunn som objekter for undersøkelse. 
Begrepet organisme forstås i et organisasjonsteoretisk perspektiv i retning av vekt på naturlige prosesser. Men begrepet brukes ikke uten videre slik i teologisk sammenheng, der det ofte mer peker mot den åndelige og usynlige dimensjonen ved kirken. Ofte er man seg heller ikke bevisst at begrepet er en metafor, noe som kan uttrykkes som «kirken er teologisk forstått ikke en organisasjon, men en organisme». At kirken er skapt av Gud, står ikke i motsetning til at den er en organisasjon. Når det finnes en kirkeorganisasjon, er det jo nettopp som en konsekvens av Guds initiativ i verden.

I diskusjonen kan det også være nyttig å skille mellom ulike fokus sosiologien kan anlegge i studiet av kirke, menighet og samfunn. Et generelt samfunnsperspektiv vil i kirkesosiologisk sammenheng omfatte kirkens og menighetenes omgivelser - hvordan samfunnsendringer påvirker kirke og menighet og eventuelt motsatt. Slike analyser vil kunne anvendes av kirken for å forstå sin plassering og sitt handlingsrom i et samfunn $i$ endring. Videre kan søkelyset rettes mot kirke- og menighetsstrukturer, for eksempel ulike menighetsstudier, kirkestatistikk eller yrkesmessige rekrutteringsmønstre. Et siste felt vil kunne være analyser av teologiske konsepter på basis av kunnskapssosiologiske innsikter.

\section{Konklusjon}

Dette kapitlet har belyst hvordan ekklesiologi og organisasjonsteori forstår kirken som fellesskap. Et sentralt argument har vært at kirke og menighet kan forstås ut fra ulike faglige tilnærminger som bør settes i dialog. Både ekklesiologi og organisasjonsteori anvender fellesskapsbegreper, dels ved hjelp av metaforer, mens andre baseres på deskriptive empiriske studier. I kirkelig sammenheng er skillet mellom organisme og organisasjon interessant som møte mellom to fagområder: teologi, gjennom ekklesiologien og kirkefagene, og organisasjons- og ledelsesfaget, med sin historie og andre begreper. Begrepsparet trekker veksler både på rasjonelle og naturlige perspektiver, som gir en fruktbar spenning. De siste tiårene har praktisk teologi sett en empirisk vending. Dette kan styrke fagområdenes dialog, men vil også nødvendiggjøre en gjennomtenkning av hvilke implisitte forutsetninger hvert fag 
og faglig perspektiv bringer med seg. Dette er et sentralt bidrag i dette kapitlet.

Kirken har benyttet seg av maler i samtiden for organisering og ledelse. Teologen Olav Skjevesland (1998, s. 18-19) omtaler forholdet mellom ekklesiologi og sosiologi som en dialog mellom «en teologisk basert kirketenkning og en sosiologisk belysning». En fortsatt utfordring er at fagområdene ikke får brukt sitt potensial i samtalen fordi det ene fagområdet blir for dominerende. Skjevesland poengterer inkarnasjonen og empiriens betydning. Før kirken er en definert sosiologisk størrelse, eksisterer den som et møte, som en oppsøkende, relasjonsskapende handling fra Gud, rettet mot det enkelte menneske i fellesskapet. Organisering bør tjene virksomhetens egenart og oppdrag. Her ligger både et normativt og et kritisk perspektiv.

\section{Referanser}

Askeland, H. (1998). Ledere og lederroller. Tapir.

Bauman, Z. (2000). Liquid modernity. John Wiley \& Sons.

Beckford, J. A. (1985). Cult controversies. The societal response to new religious movements. CUP Archive.

Bromley, P. \& Meyer, J. W. (2017). «They are all organizations»: The cultural roots of blurring between the nonprofit, business, and government sectors. Administration \& Society, 49(7), 939-966. https://doi.org/10.1177/0095399714548268

Browning, D. S. (1995). A fundamental practical theology. Descriptive and strategic proposals. Fortress Press.

Brunsson, N. (1991). Målstyring og virksomhetsplanlegging som forvaltningspolitisk strategi. I P. Lægreid (Red.), Målstyring og virksomhetsplanlegging i offentlig sektor (s. 12-29). Alma Mater.

Baasland, E. (1993). Ledelsesstrukturer i den eldste kirke. I P. O. Gullaksen, T. Austad, E. Fougner \& O. Skarsaune (Red.), Reform og embete. Festskrift til Andreas Aarflot på 65-årsdagen den 1. juli 1993 (s. 181-198). Universitetsforlaget.

Carroll, J. W. (1991). As one with authority. Reflective leadership in ministry. John Knox Press.

Clarke, A. D. (2000). Serve the community of the church. Christians as leaders and ministers. William B. Eerdmans Publishing.

Collins, J. N. (1990). Diakonia. Re-interpreting the ancient sources. Oxford University Press.

Davie, G. (2007). The sociology of religion. Sage. 
Dietrich, S. (2011). «Jeg tror på de helliges fellesskap». Teologiske refleksjoner rundt kirken som fellesskap. I S. Dietrich, T. S. Dokka \& H. Hegstad (Red.), Kirke nå. Den norske kirke som evangelisk-luthersk kirke (s. 51-73). Fagbokforlaget.

DiMaggio, P. (1992). The relevance of organization theory to the study of religion. I N. J. Demerath III, P. D. Hall, T. Schmitt \& R. H. Williams (Red.), Sacred companies. Organizational aspects of religion and religious aspects of organizations (s. 7-23). Oxford University Press.

Drucker, P. F. (1998). Management's new paradigms. NEXT, 4(6), 1-25.

Furseth, I. \& Repstad, P. (2003). Innføring i religionssosiologi. Universitetsforlaget.

Harris, M. (1995). The organization of religious congregations. Tackling the issues. Nonprofit Management and Leadership, 5(3), 261-274. https://doi.org/10.1002/nml. 4130050305

Hauglin, O. \& Hegstad, H. (2005). Evaluering av soknesammenslåing i indre Bergen by. Rapport. Arbeidsfellesskapet.

Hegstad, H. (1996). Folkekirke og trosfellesskap. Et kirkesosiologisk og ekklesiologisk grunnproblem belyst gjennom en undersøkelse av tre norske lokalmenigheter. Tapir.

Hegstad, H. (2009). Den virkelige kirke. Bidrag til ekklesiologien. Tapir.

Hinings, C. \& Raynard, M. (2014). Organizational form, structure, and religious organizations. I P. Tracey, N. Phillips, \& M. Lounsbury (Red.), Religion and organization theory (s. 159-186). Emerald Group.

Hougsnæs, M. H. (2004). Kirkesyn og kirkeledelse. Halvårsskrift for Praktisk Teologi, $21(2), 15-24$.

Lysgaard, S. (1967). Arbeiderkollektivet. En studie i de underordnedes sosiologi. Universitetsforlaget.

Martinussen, W. (1984). Sosiologisk analyse. En innføring. Universitetsforlaget.

Meyer, J. W. \& Bromley, P. (2013). The worldwide expansion of «organization». Sociological Theory, 31(4), 366-389. https://doi.org/10.1177/0735275113513264

Mintzberg, H. (1979). The structuring of organization. A synthesis of the research. Prentice Hall.

Repstad, P. (2020). Religiøse trender i Norge. Universitetsforlaget.

Rochester, C. \& Torry, M. (2010). Faith-based organizations and hybridity. A special case. I D. Billis (Red.), Hybrid organizations and the third sector: Challenges for practice, theory and policy (s. 114-133). Palgrave Macmillan.

Sandnes, K. O. (1994). A new family. Conversion and ecclesiology in the early church with cross-cultural comparisons. Lang.

Scherer, R. P. (1980). American denominational organization: A sociological view. William Carey Library.

Schillebeeckx, E. (2014). The collected works of Edward Schillebeeckx volume 9: The church with a human face. Bloomsbury Publishing. 
Schmidt, U. (2020). Nordisk praktisk-teologisk ekklesiologi: Aktuelt fagfelt og aktuelle spørsmål. Tidsskrift for Praktisk Teologi, 1, 19-31. https://journals.mf.no/ tpt/article/view/5302

Scott, W. R. (1987). Organizations. Rational, natural, and open systems. Prentice-Hall.

Scott, W. R. (2014). Institutions and organizations. Ideas, interests and identity. Sage.

Selznick, P. (1957). Leadership in administration: A sociological interpretation. Row Peterson.

Sirris, S. (2017). Å arbeide med verdier i kirken. Etisk refleksjonsveiledning og verdibevissthet i religiøse organisasjoner. Scandinavian Journal for Leadership and Theology, (4), 1-22.

Skjevesland, O. (1998). Morgendagens menighet. Ledelse og livsform. Verbum.

Thidevall, S. A. (2005). Folkkyrkans tid. Församlingsinstruktionerna berättar. Forskningsrapport om församlingarnas verklighet som den återspeglas i församlingsinstruktionerna. Ordbruket förlag.

Ward, P. (2002). Liquid church. Hendricson Publishers. 



\title{
KAPITTEL 3
}

\section{Utviklingstrekk i organisering og ledelse i Den norske kirke}

\section{Stephen Sirris}

VID vitenskapelige høgskole

\section{Harald Askeland}

VID vitenskapelige høgskole

\section{Frank Grimstad}

VID vitenskapelige høgskole

\begin{abstract}
This chapter provides an account of central aspects in the modern development of organization and leadership in the Church of Norway. By narrating the growth of organizational, managerial and professional dimensions embedded within the church, it analyzes three specific trends. Democratization refers to the emergence of councils on various ecclesial levels and the influence of lay persons supplementing pastoral authority. Corporatization denotes increased attention to organizational features including leadership and clarification of its mandate. Professionalization links to specialization of work and the growth of congregational staffs, including administrative and managerial positions. Our review of central processes shows that the trends are parallel, although some are stronger than others in specific epochs. These trends emphasize increased interaction and cooperation.
\end{abstract}

Keywords: change, church, co-creation, corporatization, democratization, professionalization

\section{Introduksjon}

Alle organisasjoner er innvevd i ulike kontekster og preges av særskilte rammebetingelser. Påvirkninger fra organisasjonsomgivelsene er ikke statiske, men dynamiske og utvikler seg over tid. I dette kapitlet tar vi derfor

Sitering av denne artikkelen: Sirris, S., Askeland, H. \& Grimstad, F. (2021). Utviklingstrekk i organisering og ledelse i Den norske kirke. I S. Sirris \& H. Askeland (Red.), Kirkelig organisering og ledelse: Et verdibasert og praksisorientert perspektiv (Kap. 3, s. 59-82). Cappelen Damm Akademisk. https://doi.org/10.23865/ noasp.129.ch 3

Lisens: CC BY-NC-ND 4.0 
opp spørsmålet: Hvilke trender har formet organisering og ledelse i Den norske kirke i prosessen fra statskirke til selvstendig folkekirke? På bakgrunn av en kortfattet historisk fremstilling retter vi oppmerksomheten mot rammebetingelser og drivkrefter som har medvirket til at kirken i dag fremtrer slik den gjør i organisatorisk, ledelsesfaglig og profesjonssosiologisk form.

Kapitlet skisserer først den historiske utviklingen fra den kongestyrte, geistlige embetskirken etter 1814 til menighetsrådsloven i 1920. Deretter beskrives viktige utviklingsfaser frem mot opphøret av statskirken i 2012 og etableringen av en fristilt folkekirke i 2017. På bakgrunn av den historiske oversikten drøfter vi så tre sentrale utviklingstrekk eller trender: demokratisering, korporativisering og profesjonalisering. Disse begrepene kan forstås som trender i betydningen kontinuerlige strømninger eller varige tendenser. En trend er dermed noe annet enn en kortvarig moteretning. Hver trend har hatt vekslende styrke gjennom tiden, og er målbåret av sine respektive talspersoner gjennom aktørgrupper som fremstår som viktige interessenter: De folkevalgte representantene har arbeidet for demokratisering, i betydningen fremveksten av kirkelig rådsstrukturer og større formell innflytelse for lekfolket. Organisasjonenes ledere og administratorer har fremmet korporativisering; at kirken blir del av organisasjonssamfunnet og fremstår som en korporasjon eller organisasjon som eget rettssubjekt med egne beslutningsorganer. Fagfolk og yrkesutøvere uttrykker profesjonalisering, som vi forstår som nye stillingskategorier med definerte kvalifikasjonskrav og dertil økt kompetanse. Et hovedanliggende i kapitlet er å vise hvordan kirken både rammes inn av og anvender organiseringsformer som eksisterer i samfunnet. Vi beskriver også hvordan organisasjonsformene bearbeides og inngår i kirkens egen refleksjon og virksomhet. De tre trendene vi analyserer er i liten grad systematisk utforsket i kirkekonteksten. Derfor er kildene langt på vei sentrale aktørers egne beskrivelser, særlig gjennom utredningsarbeidet fra statskirke til selvstendig folkekirke.

\section{Én overgang, mange prosesser}

Over tid har overgangen fra statskirke til fri folkekirke endret rammebetingelsene for organisering og ledelse i kirken lokalt, regionalt og 
nasjonalt. Denne utviklingen er dokumentert i både internasjonale og nordiske studier (Askeland \& Schmidt, 2016; Madeley \& Enyedi, 2003). Sentrale endringsfaktorer for Den norske kirke er den indre organisatoriske utvikling innenfor kirkesamfunnene som selvstendiggjøring fra staten (Askeland, 2000a), kirkemedlemmenes økende rolle i styring og ledelse av menighetene gjennom utbyggingen av rådsstrukturen (Birkedal, 2017; Grimstad, 2005), prestetjenestens kombinasjon av kallsbasert profesjon og moderne yrke (Sirris, 2019b), samt endring av autoritetsgrunnlag og legitimitet (Hougsnæs, 2005).

Selv om statskirkeordningen i Norge opphørte i 2012, oppfatter mange fremdeles kirken som semi-offentlig. Det skyldes både fortiden som statskirke og den fortsatte særskilte grunnlovfestingen i $\$ 16$ : «Den norske kirke, en evangelisk-luthersk kirke, forblir Norges folkekirke og understøttes som sådan av staten», samt annen lovgivning. I tillegg kommer delt offentlig finansiering mellom stat og kommuner, samt kirkens rolle i gravferdsforvaltningen. Det gir en nær forbindelse mellom kirken, representert ved menighetsråd og kirkelig fellesråd som soknets organer, og kommunene. Disse rammene legger føringer for kirkelig organisering ut over å være eksterne og nøytrale omgivelser for kirken. Det dreier seg om rettslige og økonomiske rammebetingelser som former handlingsrommet for kirkelig organisering og ledelse. I tillegg har innvevingen i offentlig forvaltning gitt likheter mellom kirkelig og offentlig organisering, styring og ledelse. Samtidig innebærer en fristilt folkekirke en tydeligere plassering i sivilsamfunnet, mellom offentlig og privat sektor. Fristillingen kan beskrives som en privatisering av kirken som offentlig forvaltningsområde.

Samfunnsutviklingen har beveget seg fra embetsmannsstat til organisasjonsfrihet og demokrati. Kirkens utvikling gjennom statskirkeordningen har medført at tidligere og nye organisasjonsformer eksisterer side om side. Mangfoldet utgjør et konglomerat av autoritetsformer og styringsstrukturer som kan sammenlignes med en sedimentær bergart (Repstad, 2002). Disse styringsstrukturene gjenfinnes i kirkeordningen. Historisk har de påvirket relasjonen mellom lokalt, regionalt og sentralt nivå, samt forholdet og relasjonen mellom valgte råd og representanter for geistligheten (Gullaksen et al., 1993). 
Vårt valg av tidsperioden fra kongestyrt embetsmannsstat til politisk demokrati og organisasjonssamfunn henger sammen med antakelsen om at presterollen ble preget av embetsmannsperioden, og at valgte rådsorganer samt nyere kirkelige lederroller må forstås både mot denne bakgrunnen og nyere utviklingstrekk. Teologen Ivar Asheim påpeker de tre trendene dette kapitlet drøfter, og han beskriver overgangen slik:

I embetsmannsstaten ble presten embetsmann. Da organisasjonssamfunnet vokste frem, fikk kirken i tillegg til sin embetsstruktur frivillige organisasjoner for ytre og indre misjon og diakoni. Og i vår tid kan sosiologer enda en gang konstatere hvordan den kirkelige utvikling forløper fullstendig parallelt med samfunnsutviklingen, denne gang både hva de frivillige arbeidsgrener og embetsstrukturen angår. For kirken som for samfunnet kan denne utviklingen beskrives med tre stikkord: demokratisering, byråkratisering og profesjonalisering. (Asheim, 1988, s. 9)

\section{Historisk oversikt}

Den historiske skissen fra reformasjonen frem til 1945 er summarisk og trekker veksler på den historiske gjennomgangen som beskrives i viktige offentlige utredninger: NOU 1975: 30 Stat og kirke, NOU 1989: 7 Den lokale kirkes ordning og NOU 2006: 2 Staten og Den norske kirke, samt sentrale reformhistoriske dokumenter og forskningslitteratur.

\section{En kongestyrt kirke i enhetssamfunnet}

Kimen til kirken ble etablert da Jesus samlet mennesker til fellesskap med seg og med hverandre. Likevel er det vanskelig å utlede normative utsagn om organisering og ledelse ut fra det nytestamentlige materialet (Baasland, 1993). De første kristne etablerte fellesskap med organisatoriske trekk farget av sin lokale kontekst. I oldkirken hadde menighetene i Jerusalem, Syria, Nord-Afrika og etter hvert i andre deler av det romerske riket ulike særtrekk (Baasland, 1993). Senere utviklet det seg viktige forskjeller mellom den ortodokse og katolske kirke. Den norske kirke fikk avgjørende impulser etter reformasjonen. Kirken ble organisert som en 
fyrstestyrt kirke, og var fra 1661 under kongens herredømme i enevoldstiden som i Norge varte til 1814.

I motsetning til den katolske kirke og mange andre kirkesamfunn har Den norske kirke etter reformasjonen ikke fremstått som en selvstendig korporasjon. Som livssynssamfunn har kirken vært en usynliggjort og privilegert del av statsforvaltningen (Furseth, 2015). Særlig gjaldt dette de statskirkelige ordningene hvor presteskapet og etter hvert regionale og sentrale kirkelige råd var statlig virksomhet underlagt det statlige kirkedepartementet. I lokalsamfunnet har kirken vært noe tydeligere gjennom soknets eiendomsrett til kirkene og eventuelle fond. Samtidig inngikk soknets ansvar og kirkelige virksomhet i kommunal forvaltning fra formannskapslovene i 1837, nettopp fordi soknet ikke hadde noe eget organ som kunne representere det. Denne situasjonen varte frem til kirkeloven av 1996, da soknet fikk en rettslig selvstendig stilling (Askeland, 200ob). Dermed har reformene det siste hundreåret i stor grad omhandlet en organisatorisk selvstendiggjøring av kirken (Kirke/stat-utvalget, 2001). Vi velger å anvende begrepet korporativisering (Brunsson \& SahlinAndersson, 200o). Som korporasjon eller organisasjon med egen rettslig handleevne og egne beslutningsorganer blir kirken en mer integrert del av organisasjonssamfunnet.

\section{Kirken og fremveksten av folkestyret}

For den senere demokratiseringen representerte reformasjonen en radikal endring av lekfolkets rolle og innflytelse. Det fikk større prinsipiell enn praktisk betydning. Luthers realpolitiske henvisning til fyrsten betød uendrede lederroller lokalt og sentralt i kirken. Grunnloven av 1814 videreførte den evangelisk-lutherske konfesjon som offentlig religion. Den kan best beskrives som en geistlig embetskirke styrt av kongen - regjeringen - ut fra grunnlovsbestemmelsen som gjorde kirkestyret til et kongelig prerogativ. Samtidig etablerte Stortinget seg som en aktør i kirkestyret gjennom sin bevilgnings- og lovgivningsmyndighet. Allerede i 1818 ble det vedtatt en lov som gav soknet, med amtmannens godkjenning, rett til å skrive ut skatt for å vedlikeholde kirkebygget. Ansvaret for kirke, kirkegård og lokale stillinger ble ført inn i ansvaret 
som kommunene fikk med formannskapslovene av 1837. Kommunene ble etablert ut fra daværende prestegjeldsinndeling, mens soknestyrene ivaretok et viktig ansvar for lokale forhold, inkludert kirkene (Hansen, 2016). Uten egne organer som kunne representere soknet, forble økonomi et offentlig ansvar. Her avviker Norge fra de øvrige nordeuropeiske lutherske stats- og folkekirkene, som fikk egne lokale styringsorganer og rett til å skrive ut kirkeskatt.

Fra 1840-årene vokste kravet om å gjøre kirken selvstendig fra staten. Sentralt i denne reformbevegelsen var etableringen av egne kirkelige styringsorganer (Elstad, 2005). Et slikt demokratisk element hadde allerede vokst frem i tyske fyrstedømmer ved etableringen av såkalte konsistorier for å ivareta fyrstens kirkemakt. Samtidig kom krav om at soknet måtte få egne formannskap eller lokale kirkeråd. I vår norske kontekst ble kravet om egne valgte organer sett i lys av en annen tradisjon, demokratiet. Samtidig var bakgrunnen knyttet til fremveksten av den haugianske vekkelsen og fremmet av pietistiske representanter fra bondestanden gjennom vedvarende forslagsstilling i Stortinget (Seland, 2018).

Styrket demokrati regulerer enkeltindividet i samfunnet og innebærer en utbredelse av rettigheter og plikter til alle deler av folket. I Norge ble det kirkelige demokrati innført i mange av lekmannsorganisasjonene fra 1840-årene (Elstad, 2005). Lov om menighetsrådene ble vedtatt i 1920, men ble ikke ledsaget av ledelsesrefleksjoner. Menighetsrådenes oppgaver ble definert som åndelige, mens kommunestyrene ivaretok forvaltning og økonomi. Soknepresten ble medlem av menighetsrådet og fungerte som dets reelle leder frem til 1960-årene. Bispedømmerådene ble etablert i 1933 og fikk sekretærhjelp som etter hvert utviklet seg til stiftsdirektører. Her ble biskopene selvsagte medlemmer og ivaretok statens interesser ved å forhindre at rådene utviklet seg til demokratiske maktorganer.

\section{Kirkelig reformbevegelse og etterkrigstidens samfunnsutfordringer}

Etterkrigstiden ble preget av gjenoppbygging av landet og sosialdemokratiske idealer. Det var optimisme og gründervirksomhet gjennom en utstrakt kirkelig og diakonal institusjonsbygging. Organisasjoner som 
Kirkens Nødhjelp, Institutt for kristen oppseding (IKO) og Menighetspleienes Landsforbund ble etablert (Rødahl, 1988). Sentralt i arbeidet med å selvstendiggjøre Den norske kirke som trossamfunn, står reformbevegelsen. Denne bevegelsen var i mindre grad organisert, men bestod av en rekke sentrale kirkelige aktører som bidro i oppbyggingen av kirkelige organer og rådsstrukturer. Reformbevegelsen tok utgangspunkt i menigheten som kirkens kjerne, og fremholdt gudstjeneste og nådemiddelforvaltningen som kirkens sentrum. I denne forståelsen var oppdraget gitt hele menigheten, og prest og menighet stod i gjensidig avhengighet og uavhengighet til hverandre. Videre rommer embetet, ifølge reformbevegelsen, et mangfold av spesialiserte arbeidsfelter. På dette grunnlaget har særlig biskop Andreas Aarflot understreket at kirkestyret prinsipielt ikke kan ligge hos staten (Aarflot, 1990). Statskirkeordningen er en arv fra reformasjonen hvor kongen tok ansvar for å ordne kirkelivet med en myndighet delegert av kirken. Stortingets behandling av kirkeordningsloven (1953) gav lite resultat, selv om menighetsrådenes og bispedømmerådenes ansvar ble klargjort. Fra slutten av 1950-tallet så Norsk Menighetsinstitutt dagens lys og betød mye for kirkelig aktivitet. Ledelse var fortsatt lite tematisert, og ble overlatt til lokale forhold (Skjevesland, 1994). De kirkelige oppgavene i drabantbyene stod i kø og ventet på å bli løst. Som medlem og leder av menighetsrådet var presten fremdeles den ubestridte leder i lokalkirken og oftest den eneste heltidsansatte i menigheten.

1960-tallet var preget av aktivitetskirken, men også økende behov for utredning og avklaring når det gjaldt kirkens rolle, struktur og reformer. Dette resulterte i to viktige utredninger: Reform av Den norske i 1969, utarbeidet av Birkeli-kommisjonen (Reformkommisjonen), og Den norske kirke og Staten i 1973 skrevet av Støylen-kommisjonen (Utredningskommisjonen). Begge utredningene poengterte at menigheten er kirkens sentrum. Alle andre kirkelige organer skulle føre sin eksistensberettigelse tilbake til menigheten og være til støtte for menighetens arbeid (Reformkommisjonen, 1969; Utredningskommisjonen, 1973). Gjennom 1960-tallet ble nye kirkelige aktiviteter ytterligere styrket ved lovfesting av stillinger som klokker (1963), organist (1967), kateket (1969) og diakon (1986). Utviklingen av menighetsstaber med røtter i denne perioden kom 
senere til å representere gryende ledelsesutfordringer. Menighetssekretærer ble ansatt mange steder og ivaretok sentrale ledelsesoppgaver uten formelt mandat. Støylen-kommisjonen ble fulgt opp av staten gjennom Sivertsen-komiteen, som leverte utredningen Stat og kirke i 1975 (NOU 1975: 30). Flertallet av komitemedlemmene gikk inn for å etablere en fri folkekirke. Høringsrunden gav likevel klart flertall for å beholde statskirkeordningen, men menighetsrådene ønsket omfattende reformer. Det medførte at stor oppmerksomhet de neste femti år var rettet mot relasjonen mellom kirke og stat. Mindre endringer i kirkeordningsloven gav hjemmel for opprettelse av Bispedømmerådenes fellesråd, også kalt Kirkerådet, i 1969. Dette nyopprettede Kirkerådet tok i 1970-årene opp en rekke prinsipielle og praktiske spørsmål for å rydde og strukturere i organisatoriske og ledelsesmessige spørsmål. Noen viktige utredninger fikk stor betydning for utforming av lederroller, nemlig Embetsteologi og tjenestedifferensiering (Kirkerådet, 1975) og Tjenester og stillinger (Kirkerådet, 1977/81).

Embetsteologien ble gjenstand for refleksjon og debatt, ikke minst med bakgrunn i opprettelsen av kateketstillinger i 1969 (Ulstein, 2019). I likhet med prestestillingene ble kateketstillingene opprettet av staten. Departementet tilsatte begge tjenestegruppene. Begrunnelsen for kateketstillingene var delvis i behovet for å møte de store utfordringene som fulgte etter grunnskoleloven i 1969, samt å gi de store kullene av barn og ungdom kirkelig oppmerksomhet. Samtidig medførte stillingskategorien utfordringer for ledelse i menigheten, siden det var uklart hvem som skulle være kateketens overordnede. I heftet Tjenester og stillinger (1976) gav Kirkerådet et bidrag til avklaring i struktur og ledelse. Dette viste en viss uenighet mellom Kirkedepartementet og Kirkerådet om myndighet til å utforme stillingsstrukturen. Departementet argumenterte mot at Kirkerådet utformet lederrollen for prester, en oppgave departementet fastholdt var et statlig ansvar. Uenigheten ble til en viss grad løst i den reviderte utgaven av heftet i 1981. Tiåret ble avsluttet med stortingsmeldingen Om stat og kirke (St. meld. nr. 40 (1980/81)). Meldingen og behandlingen i Stortinget pekte mot fortsatte reformer innenfor statskirkens rammer, men løste ikke ledelsesutfordringene i lokalmenigheten. 


\section{I retning av en selvstendig folkekirke}

1980-tallet var et viktig tiår for kirkelig organisering og ledelse (Gullaksen, 1993). Stortingsmeldingen Om stat og kirke (St. meld. nr. 40 (1980/81)) var sentral. Ot. prp. nr. 74 (1982-1983) førte til opprettelse av Kirkemøtet, og i tillegg kom de offentlige utredningene Den norske kirke og loren (NOU 1985: 21) samt Den lokale kirkes ordning (NOU 1989: 7). Kirkerådet initierte følgende utredninger for organiserings- og ledelsesforståelsen: Kirkens Personalråd (1982), Kirkens Arbeidsgiverorganisasjon (1986) og Kirkens embete og råd (Kirkerådet, 1987). Reformbevegelsen seiret med skjellsettende kirkelovsendringer i 1984 som innebar lovfestede bispedømmemøter og det årlige Kirkemøtet som øverste representative organ med Kirkerådet som utøvende organ. Bispedømmerådenes fellesråd, lovfestet i 1970, var en forløper for Kirkemøtet.

Effekten av Sivertsen-komiteen (NOU 1975: 30) og Stortingets behandling av kirkens ordning og tilknytning til staten frem mot 1996, var løsning på tre utfordringer. For det første ble den lokale kirke enda mer frikoblet fra geistlig tjeneste ved at flere menigheter etablerte stilling som daglig leder, noe som bidro til ytterligere utfordringer hva gjaldt enhetlig ledelse lokalt. For det andre fikk rådene teologisk og kirkerettslig legitimitet som styringsorganer. For det tredje måtte et styrket personalansvar ta utgangspunkt i de lokale rådenes ansvar, og kunne ikke forankres i Kirkemøtet. 1990-tallet satte ledelsesspørsmål for fullt på dagsorden på ulike måter. Presteforeningen påbegynte kurs i pastoral lederutvikling for sokneprester, mens Kirkerådet bidro med heftet Samarbeid i menigheten (Grimstad, 1983). Kirkevergelaget ble opprettet, og etablerte i samarbeid med Kirkens arbeidsgiverorganisasjon lederopplæring for kirkeverger.

1990-tallet var preget av en rekke begivenheter med betydning for ledelsesforståelsen primært i lokalkirken. Etter en lengre prosess ble Lov om Den norske kirke (kirkeloven) vedtatt av Stortinget i 1996. Loven innførte selvstendighet for soknet og innførte daglig leder-betegnelsen på alle nivåer i kirken. I dette arbeidet var presten ikke et tema for lokalkirkens ledelse, noe som viser en tydeligere todeling av kirkeledelse. Todelingen kom klart frem i det videre arbeidet med artikulering av ledelsesforståelsen i det geistlige hierarki gjennom nye tjenesteordninger for menighetsprester, prost og biskop. Kirkerådet tok i høyere grad fatt 
på reformarbeid og arbeidsgiverutredning. Kirkens arbeidsgiverorganisasjon (heretter KA) ble opprettet som interesseorganisasjon for menighetsråd og fellesråd i 1990, og som formell arbeidsgiverorganisasjon fra 1996. Det kom egne kirkelige tariffavtaler og lederavtaler. Det var større aktivitet i forskning og utredning for å forstå kirkelig ledelse (Askeland, 1998; Huse, 1998, 2000). Kirkedepartementet gjorde begrepet pastoral ledelse eksplisitt i tjenesteordningen for menighetsprester.

2000-tallet var preget av revisjoner av tjenesteordninger for menighetsprest, prost og biskop (Sirris, 2019b; Stifoss-Hanssen et al., 2013). Det har bidratt til å profilere kirkeverge og prost som ledere for hver sin virksomhet. I begynnelsen av 200o-tallet initierte KA overfor Bispemøtet og Kirkerådet å gjennomføre kurs i alle bispedømmer. Kurset fikk navnet «Sammen om å lede», og fikk varierende oppslutning i de ulike bispedømmer.

\section{Sentrale utviklingstrekk}

Gjennomgangen har så langt vært kronologisk. Det følgende belyser tematiske utviklingstrekk som har vært gjennomgående strømninger og preget ledelsestenkningen. Vi strukturerer disse i tre hovedtrender som vi drøfter i det følgende: demokratisering, korporativisering og profesjonalisering.

\section{Demokratisering}

Demokrati er en styrings- og ledelsesform som sikrer maktfordeling. Samfunnslivet har i økende grad kommet under demokratisk kontroll. I utgangspunktet gav denne styringsformen statsborgerne makt uten krav om tilgang til eiendom og kapital. Denne makten ble kanalisert gjennom politiske partier, faglige sammenslutninger og etter hvert også interessegrupper. Dette har også skjedd parallelt i kirken, om enn i noe mindre omfang. Rådsstrukturen er bygget opp fra lokalt til nasjonalt nivå, og tiltaksorienterte, arbeidstakerorienterte og interesseorienterte organisasjoner har engasjert seg. Et hovedspor i utviklingen er at kirkelige organer har tematisert ledelsesspørsmål siden midten av 1980-tallet. Dette har, 
som den kronologiske gjennomgangen viser, resultert $\mathrm{i}$ etableringen av to selvstendige arbeidsgiver- og ledelseslinjer. Å nærme seg en diskusjon av lederroller har like fullt vært problematisk. En viktig drivkraft har vært premisset om at en ny kirke trenger en ny organisering. Skal de kirkelige styringsorganene fungere, trenger de en handlingsorganisasjon representert ved lederstillinger og administrative ressurser til saksbehandling.

Et sentralt element i utviklingen var den vedvarende reformprosessen innledet med kirkeloven i 1897 og fulgt opp i menighetsrådsloven i 1920 (Voksø, 1993). Prosessen ble avsluttet med det formelle opphøret av statskirkeordningen i 2012, etableringen av Den norske kirke som rettssubjekt i $2017 \mathrm{og}$ felles trossamfunnslov som trådte i kraft i 2021. Den tidlige selvstendiggjøringen skjedde gjennom en tiltakende differensiering i det statlige kirkestyret. Mens den geistlige tjeneste og gudstjenestelivet lenge var et ansvar for Kongen og regjeringen, spilte Stortinget gjennom sin lovgivnings- og budsjettmyndighet en stadig økende rolle i etableringen og utformingen av den nasjonale og lokale strukturen, blant annet med lovfestingen av demokratiske organer. Denne utviklingen ble drevet frem av kirkelige aktører og organer gjennom reformbevegelsen (Askeland, 2000a; Kirke/stat-utvalget, 2001). I denne prosessen har det vært noen sentrale anliggender. Kirken måtte anerkjennes som en selvstendig korporasjon overfor stat og samfunn, og denne selvstendigheten måtte få sitt uttrykk i representative organer: «Ledelsen av kirken må utgå fra den kristne menighet og prinsipielt ligge hos kirken selv, ikke hos noen myndighet utenfor den» (Utredningskommisjonen, 1973, s. 110). De kirkelige organenes styringsansvar har fått en viss kirkelig refleksjon og legitimitet, blant annet ved sentrale aktører innenfor reformbevegelsen:

Det er således god grunn til å se de representative strukturer i de historiske kirker som uttrykk for det bibelske prinsipp om kollektivt ansvar for kirken blant alle dens medlemmer. Praktisk talt er de styrende organer og råd i en kirke manifestasjoner av og redskaper for den kollektive styringsmyndighet hos alle som har del i de troendes prestedømme. (Aarflot, 1990, s. 28)

I debatten som fulgte omkring fordeling av styrings- og lederansvar i kirken, var endringene i kirkeordningen ønsket fra kirkelig hold. Den prinsipielle grunnholdningen som Aarflot (1990) målbar, gjenfinnes i 
de fleste dokumentene fra reformbevegelsen, offentlige utredninger og andre indrekirkelige utredninger. ${ }^{1}$ Eksempelvis vektla Hille-utvalget menighetenes rettslige og økonomiske status, ikke minst relatert til kommunen (NOU 1989: 7).

Prosessen har medført at sentrale rammer rundt prestetjenesten ble endret og nye organer og aktører kom til. Fra å være det eneste myndighetsorganet i lokalmenigheten, er det nå flere organer som har ansvar for tradisjonelle pastorale oppgaver. Et viktig grep var å plassere ansvar for «innarbeiding av kirkelig undervisning, diakoni og kirkemusikk» til menighetsrådet (Kirkeloven, 1996, \$9) og det tilhørende arbeidsgiveransvaret for stillinger til kirkelig fellesråd $(\$ 14)$. Rådenes utvidede virksomhetsansvar, med tilhørende ansvar for ressursene, medfører at det nå er menighetsråd og kirkelig fellesråd som fremstår som menighetenes representative styringsorganer. Prestetjenesten er representert som fast medlem i rådene (Voksø, 1993). Denne utvikling av demokratisk valgte organer med ansvar for lokal kirkelig virksomhet var helt i tråd med den kirkelige reformbevegelses og kirkens ønsker slik disse fremkom på Kirkemøtet i 1994. Fra samme tidspunkt som profesjonslovene ble opphevet fikk Kirkemøtet kompetanse til å fastlegge tjenesteordninger, vigsling og utdanningskrav for kateketer, diakoner og kirkemusikere. Staten opprettholdt prestetjenesten som et statlig ansvar frem til 2017. Utviklingen reiste enkelte utfordringer for prestetjenesten. For mange kirkelig tilsatte var det uvant å få en daglig leder å forholde seg til. Situasjonen inntil ny kirkelov i 1996 var mange steder preget av fravær av aktive arbeidsgivere og styringsorganer (Askeland et al., 1998; Grimstad \& Askeland, 1999). Det er ikke ukjent at også mange blant diakoner, kateketer og kantorer hadde en viss reservasjon mot at fellesrådene og kirkevergene skulle ivareta ledelse av deres yrkesutøvelse. Fenomenet er ikke særkirkelig, men godt kjent som allmenne utfordringer i styring og ledelse av profesjoner og kunnskapsarbeidere (Sirris, 2019a).

1 Dette gjelder for eksempel for Reformkommisjonen 1969; Hauge-komiteen 1973; Utredningskommisjonen 1973; NOU 1975: 30 (Om stat og kirke); Voksø-utvalget 1989; NOU 1989: 7 (Hilleutvalget); Köhn-utvalget (Kirkens embete og råd) 1987; Myndighetsutvalget 2001; Oppgavefordelingsutvalget 2002; Kirke-stat utredningen 2002; Fremtidig organisering av arbeidsgiveransvar 2008. 
Selvstendiggjøringen av Den norske kirke, med opphør av selve statskirkeordningen, medførte et tydelig fokus på demokratisering som et viktig premiss. Fra kirkelige utredninger ble det vektlagt at kirkens organer dermed ikke lenger ville hente myndighet fra offentlige organer, men få myndighet som medlemmenes organer og uttrykke det allmenne prestedømmets styringsansvar (Kirke/stat-utvalget, 2001. Fra statens side var styrking av demokratiet og økt valgdeltakelse sett som en forutsetning for å gi kirken mer selvstendighet. Dette ble konkretisert i demokratireformen, som skulle øke oppslutningen om kirkelige valg og dermed organenes legitimitet (Saglie \& Segaard, 2011).

Med ny trossamfunnslov som trådte i kraft i 2021 ble Kirkemøtet etablert som Den norske kirkes øverste representative organ, og overtok som kirkestyre myndigheten som tidligere tillå Kongen og regjeringen. Som ledd i selvstendiggjøringen av kirken, har derfor gjennomføringen og oppslutningen om de kirkelige valg fått særlig oppmerksomhet (Saglie \& Segaard, 2011; Schmidt, 2011). Det siste tiåret har det også blitt etablert praksis med flere lister til regionale og sentrale kirkelige valg, noe som tydeliggjør politiske og interessehevdende sider ved kirkedemokratiet. I denne siste perioden har Kirkerådets valgte leder hatt et visst frikjøp for å ivareta den demokratiske lederrollen.

\section{Korporativisering}

Den andre hovedtrenden i utviklingen handler om at kirken i større grad fremstår som en selvstendig organisasjon med voksende behov for administrative funksjoner. Dette utgjør en nødvendig oppbygging av forvaltning i en mer selvstendig kirke. Kravet om reform og selvstendiggjøring har også nødvendiggjort artikulering av kirkens korporative side. Utover å hevde en egenartet identitet avgrenset fra samfunn og stat, har reformbevegelsen bidratt til korporativisering eller «organisasjonsgjøring» (Brunsson \& Sahlin-Andersson, 200o) av kirke og menighet. I kirken har denne prosessen vært drevet av flere faktorer: Kirkens ønske om selvstendighet fra staten, argumenter om lekfolkets rett og visjonen om en levende menighet og lokalt kirkestyre. Det religiøse livet beskrives ofte i sivilsamfunnets kategorier, mens strukturen er preget av offentlig 
forvaltning. Som vi har sett, bidro reformbevegelsen til oppbygging av rådsstruktur samt å initiere tiltak utenfor det statlige kirkestyret.

Det er et viktig poeng at endringene som fulgte med selvstendiggjøringen ikke utelukkende ble drevet frem av teologisk refleksjon, men gjenspeiler den generelle utviklingen i statlig forvaltning (Gullaksen, 1993, s. 51). Særlig gjelder det forvaltningsreformenes vekt på målstyring, desentralisering, rammestyring og selvstendig virksomhetsansvar (Askeland, 2000a).

Organisasjonssamfunnet er etablert som en betegnelse på det moderne samfunnet, der organisasjoner fremstår som den dominerende sosiale formen (Bromley \& Meyer, 2017; Meyer \& Bromley, 2013). Fremveksten av korporative aktører med legal status og handleevne; juridiske personer eller selvstendige rettssubjekter, har endret næringsliv, offentlig tjenesteproduksjon og sivilsamfunnet. For å forstå kirkelig utvikling er det interessant at først soknet og deretter Den norske kirke er definert som selvstendige juridiske enheter med egne styringsorganer og en etablert ledelsesstruktur som kan representere og utøve ansvar på vegne av soknet og kirken, både alene og i fellesskap. Den viktigste konsekvensen for denne debatten er knyttet til lederskapets forankring, som en organisatorisk funksjon med mandat og autorisasjon fra organisasjonen (Gullaksen et al., 1993).

Samtidig har flere påpekt at utbredelsen av organisasjonsbegrepet til nye felter også har sammenheng med reformbestrebelser, eller er blitt en konsekvens av dem (Røvik, 2012). Flere sentrale konsekvenser følger av korporativiseringen, som en generell trend i samfunnsutviklingen og for kirken som en følge av reformprosessen. Da staten gjennom reformprosessen delegerte myndighet til bispedømmerådene i økonomi- og tilsettingssaker og etablerte soknet som juridisk enhet med representative organer, ble rammevilkårene for virksomhetsansvaret endret med påfølgende konsekvenser for økonomiansvar og arbeidsgiveransvar (Askeland, 2000a). Ivaretakelsen av dette nye ansvaret drev frem behovet for etablering av en handlingsorganisasjon, eller administrasjon, som kunne lede og forvalte på vegne av de valgte organer. Lokalt skjedde dette gjennom lovfesting av stilling som daglig leder på kommunenivå, men også regionalt og sentralt var det utviklet bispedømmeadministrasjon og et 
kirkerådssekretariat for å ivareta ansvar på vegne av bispedømmeråd og Kirkemøtet.

Organisatorisk gir kirken eksempler på mange og komplekse former. Daglig leder-begrepet ble innført for å gi demokratiske organer en handlingsorganisasjon for å bygge demokratiet. Plassering av arbeidsgiveransvaret hadde som en konsekvens at man ble forpliktet på arbeidsrettslig lovgivning og hvem som leder arbeidet i arbeidsgivers sted; kirkelig fellesråd. Det gav sterkt fokus særlig til organisatorisk forankring og har bidratt til å styrke kirkevergerollen. Kirkemøtets kompetanse til å fastlegge vigsling og kvalifikasjonskrav omfattet ikke daglig leder-stillingene, derved har kirkeliggjøringen av daglig ledelse vært noe mindre vektlagt. Det var opp til arbeidsgiver fullt ut å fastlegge kvalifikasjonskrav. Da strukturen for den lokale kirke var på plass, startet arbeidet i kirkelige organer med å drøfte en fremtidig kirkelig organisasjon der kirken som organisasjon ikke bestod av to strukturer, rådsbasert og geistlig, men en helhetlig kirkelig organisasjon. Sentralt i dette stod refleksjon og utredning om hvor et felles arbeidsgiveransvar i fremtiden skulle plasseres, et utrykk for at en selvstendig korporasjon måtte tenke gjennom hva som var en tjenlig og effektiv organisering. Kirkens historiske innveving i kommune og stat har gitt kirken et sterkt offentligrettslig preg, og kirken har måttet forholde seg til utviklingen i offentlig forvaltning. Dette har preget forståelse av ledelse, økonomistyring og åpenhet i saksbehandling. Ettersom den offentlige reguleringen er blitt mer omfattende legges stadig nye forpliktelser overfor organisasjonen til daglig leder. Siden lovgivningen har vokst, er arbeidslivet mer regulert. Det medfører flere rettigheter og plikter både for arbeidsgiver og arbeidstakere. Det er blitt mer omfattende å ha arbeidsgiveransvar. Dette innebærer en formalisering av ledelse og en likedanning mellom organisasjoner i samfunnet om hvilke forventninger og hvilket innhold som ligger i ledelse. Et kirkelig særtrekk i tråd med samfunnsutviklingen, er at bispeembetet er styrket gjennom arbeidsgiveransvar og økt tilsynsmyndighet. Det gjenspeiles i tjenesteordningene (Askeland, 2015).

Også før kirkeloven av 1996 hadde menighetsrådene et omfattende virksomhetsansvar. Hovedforskjellen er at selvstendiggjøringen som skjedde overfor kommunene, gav soknet juridisk handleevne og selvstendig ansvar for økonomi og tilsettinger. Menighetsrådene har et omfattende ansvar for 
kirkelig virksomhet lokalt, i samme grad som de har økonomiske ressurser. Kirkelig fellesråd er det organ som handler på vegne av soknet når det gjelder forvaltning av bygg og anlegg, planarbeid, arbeidsgiveransvar og økonomi. Konsekvensen for ledelse av lokalt kirkelig tilsatte var markert, og er beskrevet slik:

Ny kirkelov medførte at man fikk fastslått hvem som var arbeidsgiver. Alle tråder fører til kirkelig fellesråd. Juridisk sett er myndigheten positivt avgrenset. Det innebærer at myndigheten ligger i fellesrådet dersom det ikke fastslått at den ligger hos andre. Dette innebærer at man fra fravær gikk til arbeidsgivers nærvær også på den måten at Stortinget lovfestet en «daglig leder» som skulle være arbeidsgivers representant i det daglige. (Grimstad, 1999, s. 60)

Mange steder ivaretok soknepresten i ulik grad et slikt ansvar grunnet manglende mulighet for rådene til å ivareta dette ansvaret på sin fritid. Flere steder hadde det imidlertid vært arbeidet systematisk, også etter påtrykk fra sokneprester, for å opprette fellesråd og stilling som kirkeverge før loven. Sentralt her var også at Kirkedepartementet i to rundskriv i 1987 og 1988 oppfordret kommunene til å opprette lønnede kirkevergestillinger og antydet hvilke oppgaver disse skulle ivareta. Der slik stilling ble opprettet, gikk kirkevergen naturlig inn i funksjonene som personalansvarlig og leder i arbeidsgivers sted. Slik sett var kirkeloven på mange måter en kodifisering av en prosess som allerede hadde utviklet seg. Det var opprettet 250 kirkevergestillinger før loven trådte i kraft, blant annet som en naturlig tilpasning til rådenes ansvar og endringer som skjedde i kommunene etter at kommuneloven kom i 1993 (Raustøl, 1993). I perioden har disse stillingene blitt naturlige og anerkjente lederstillinger (Fiske, 2017; Mjånes, 2017). Også for prestetjenesten har denne utviklingen hatt konsekvenser (Askeland \& Schmidt, 2016; Sirris, 2013, 2019a): Fra å være embetsmenn ble prestene statstjenestemenn. Dessuten har det gjennom tjenesteordninger, og ikke minst gjennom forsøk med omorganisering av prestetjenesten, skjedd markerte endringer innenfor den geistlige tjenestelinjen. Biskopen leder prestetjenesten, og prosten er blitt tydeligere mellomleder for prestetjenesten i prostiet.

Selvstendiggjøring og korporativisering med fremveksten av en selvstendig kirkelig organisasjon innebærer endringer i forankring av 
virksomhetsansvar, og dermed for utøvelse av styring og ledelse. Det lokale elementet har blitt styrket gjennom organisatoriske uttrykk for menighetens selvstendighet og styringsmyndighet. Den moderne organisasjonsforståelsen og det moderne arbeidsgiverbegrepet trekker i samme retning: Ledere får sitt mandat fra organisasjonen og utøver ledelse innenfor rammer som settes av styringsorganet. Biskoper, proster og sokneprester er faste og fullverdige medlemmer av kirkens demokratiske styringsorganer på alle nivåer.

\section{Profesjonalisering}

Svært mye av virksomheten i kirken, som i andre organisasjoner, ivaretas av profesjonene. Avklaringen mellom stillinger og i stillinger var viktig for å sette styring og ledelse på dagsorden. Embetsteologi og tjenestedifferensiering var i så måte en relevant utredning, men gav få faktiske konsekvenser. Det var først med Porvoo-avtalen at vigsling i sammenheng med forståelsen av det kirkelige embete og tjenester ble et viktig kirkelig anliggende (Hegstad, 2009). Avtalen gjelder fullt kirkefellesskap mellom de lutherske folkekirkene i Norden og Baltikum og de britiske og irske anglikanske kirkene. Kirkemøtet gav i 1994 sin tilslutning til avtalen. Vigsling ble omfattende og medførte en rekke utredninger, ikke minst bidro dette til at Bispemøtet og Kirkemøtet gjorde vedtak som understreket at kirken trenger en tjenesteteologi. Et viktig bidrag til ledelsestenkning var forståelsen av at daglig leder-funksjonen ble lovfestet og åpnet for lekfolk. Understreking av vigslingens betydning og det å vigsle stadig flere, har styrket bisperollen og i noen grad skapt inntrykk av å avgrense demokratisk styring. Kurs og kompetanseutvikling, ikke minst «Sammen om å lede» og utvikling av ledelsesteori i kirken, har et stykke på vei gitt et felles og mer nyansert språk.

Opprettelsen av KA er et uttrykk for profesjonalisering av arbeidsgiveransvaret i Den norske kirke. Kirkemøtet behandlet i 1984 opprettelsen av Kirkens Personalråd som et underutvalg, men vedtok å utrede en egen arbeidsgiverorganisasjon som ble etablert i 1990. Dette understreket den selvstendiggjøringen lokalkirken var i ferd med å oppnå. Kirkemøtet anbefalte en organisasjon bygget nedenfra som kunne hjelpe menighetene 
i et vidt spekter av oppgaver. KA var først assosiert medlem av Norske kommuners Sentralforbund ettersom soknene ikke hadde eget juridisk arbeidsgiveransvar. I Kirkens personalhåndbok beskriver Grimstad (1990, s. 8) selvstendiggjøringen og korporativiseringen som kirkelige organer stod overfor:

Kirken er et organisk fellesskap og et troens samfunn. Men kirkens organiske liv kan ikke løsrives fra dens organisatoriske ordninger. Nettopp arbeidsgiveransvaret ligger i dette spenningsfeltet: Menighetens liv ut fra kall, nådegaver og tjenester og arbeidslivets til dels kompliserte spilleregler med økende vekt på medbestemmelse og medansvar. Kirken burde ha viktige bidrag i en slik utvikling der samvirke og samarbeid mot felles mål blir nøkkelord.

Med kirkeloven av 1996 ble KA en selvstendig arbeidsgiverorganisasjon. Formålet var å ivareta medlemmenes interesser og arbeide for en hensiktsmessig lokal kirkelig forvaltning. KA brukte arbeidstvistloven som formell part. Det bidro til organisasjonsgjøringen av lokalkirken gjennom opplæring i forhandlinger og medbestemmelse. Dermed bidro KA i reformprosessen til å styrke demokratisering og korporativisering ved å ta $\mathrm{i}$ bruk arbeidslivets vanlige terminologi samt profesjonalisering av daglige ledere og valgte rådsmedlemmer.

Med den økende vekt på ulike organisasjoner som ivaretar ulike oppgaver i samfunnet og med de behov for ivaretakelse av ulike interne funksjoner i organisasjoner, er grunnen beredt for de siste nøkkelaktørene: profesjonene. Det har vært diskusjon om vigsling og kvalifikasjonskrav til stillingene. De siste årene er begrepet vigsling benyttet fremfor ordinasjon. Dermed er tjenestegruppene retorisk blitt likedannet. Vigsling er en åndelig handling gjennom forbønn som understreker faglighet, samtidig som det er et kirkelig uttrykk for offentlig autorisasjon.

Siden den amerikanske teologen Samuel Blizzard (1956) gjennomførte sin banebrytende rolleundersøkelse av protestantiske prester i USA på midten av 1950-tallet, har rolleteori og profesjonsbegrepet i økende grad preget forståelsen av presters arbeid og tjeneste. Gjennom økende vekt på formell teologisk utdanning styrket prestetjenesten sine profesjonskjennetegn. Med andre ord skjedde en økt profesjonalisering. I en omfattende undersøkelse av pastoralt lederskap var det et gjennomgånde trekk at 
presters utdanning, karriere, lønn og lederstil sammenlignes med øvrige profesjoner i samfunnet (Carroll \& McMillan, 2006). Den første prestestreiken $\mathrm{i}$ kirkens historie ved årsskiftet 2020/21, er ett uttrykk for det. Tilsvarende forskningsinteresse hva gjelder kyrkoherdens lederrolle finnes også i Sverige (Bäckström et al., 2004; Hansson \& Andersen, 2008). I teoretisk tilnærmingsmåte ble det valgt organisasjonsperspektiver som anså kirken som en organisasjon med profesjonelt lederskap, og med presten som den naturlige leder ut fra sin profesjonelle kompetanse (Bäckström, 1996).

Dette er også situasjonen i Norge, med en økende vekt på profesjonalisering av arbeidsgiverfunksjonene og med målrettet arbeid med lønnsspørsmål, etterutdanningsspesialiseringer og ordnede arbeids- og fritidsordninger. Samtidig er det et trekk som gjerne overses i denne debatten. Prestens tidligere lederrolle som sentral kirkelig profesjon har gradvis blitt utfordret gjennom demokratisering og korporativisering. Med de nye kvalifikasjonskravene som Kirkemøtet fastsatte for øvrige vigslede tjenester har fremveksten av masterutdanninger for diakoner og kateketer skutt fart, mens kantorene over noe lengre tid har hatt mulighet for å ta et profesjonshovedfag. Derimot finnes det ingen kvalifikasjonskrav til daglige ledere og kirkeverger. I tillegg har VID vitenskapelige høgskole i 15 år hatt en masterutdanning i verdibasert ledelse med kirkelig ledelse som fordypningsløp. Utdanningen har særlig vært attraktiv blant kirkeverger og daglige ledere i menighet, men også for prester, diakoner og kateketer. Det er fremdeles spenninger rundt dette spørsmålet, med linjer til diskusjonen omkring embetsteologi og tjenesteteologi, samt til kirkefaglig ledelse. Korporativiseringen av kirken har også medført en profesjonalisering av lederrollen, noe som gjør det mer krevende å kombinere aktiv fagstilling med lederstilling. Samtidig vil nærhet til faget og praktisering av det kunne være en ressurs.

\section{Konklusjon}

Innledningsvis reiste vi spørsmålet om hvilke trender som hadde formet Den norske kirkes organisering de siste 150 år. Både den historiske gjennomgangen og drøftingen har måttet bli summarisk. Samtidig mener 
vi at dette kapitlet har gitt en oversikt over sentrale utviklingstrekk for kirkens organisering og ledelse. Ved en tiltagende delegasjon og selvstendiggjøring ble den interne diskusjonen om relasjonen mellom nivåer og linjer i kirken aktualisert. Vi har drøftet tre hovedtrender i utviklingen. Om vi skulle peke på hvilke trender som har samvirket eller vært sterkere i formingen, kan følgende svar antydes:

For det første har korporativisering og demokratisering virket samlet i en tidlig fase. Fra rundt 1840 argumenteres det først for at kirken må tilkjennes en korporativ form som tydeliggjør at den er noe annet enn et statlig religionsvesen. En eventuell korporativisering ville kreve etablering av egne organer, og her fremstår demokratisering med fremvekst av råd på ulike nivår i kirkeorganisasjonen som en naturlig løsning. Endring har skjedd i en vekselvirkning mellom kirkelige reformkrav, formet delvis av eksisterende ideer om organisering, samt statens reformvilje og egne konsepter for forvaltningsutvikling. Særlig har utviklingen av demokratisk valgte organer i kirken bidratt til å endre styrings- og ledelsesstrukturen. I tillegg har andre lederroller enn de geistlige blitt tydeligere.

Det fører til det andre hovedpoenget, nemlig at selvstendiggjøring og demokratisering har styrket korporativisering ved at organene har trengt en administrativ handlingsorganisasjon. Prosessen i retning opphør av statskirkeordningen og selvstendiggjøring av kirken har medført at kirken må utvikle egen organisatorisk kapasitet til å ivareta forvaltning av oppgaver som er overført. Kirken som forvaltningsorganisasjon er styrket, og ivaretar omfattende administrative funksjoner som inngår i ledelsesoppgavene til både kirkeverger og proster.

For det tredje har kirken sett økende grad av profesjonalisering, der også andre nye profesjoner og tjenester supplerer prestetjenesten. Det representerer en bred vifte av oppgaver som kvalitetssikres gjennom formelle kompetansekrav og fremveksten av menighetsstaben med ulike spesialiseringer. Veksten i menighetsstabene har økt behovet for tydelige lederstillinger, men også lagt et visst press på deres innretning. Profesjoner har ofte en iboende tendens til å foretrekke å bli ledet av egen profesjon med vektlegging av faglig ledelse.

De tre utviklingstrekkene demokratisering, korporativisering og profesjonalisering kan sees som trender som i et samspill har skapt viktige 
endringer. Trendene har ført til et større mangfold av aktører i kirken, og dermed en mer kompleks organisasjon. Kapitlet viser at disse tre hovedtrendene er parallelle og fremhever betydningen av økt samhandling internt i kirkeorganisasjonen. Samtidig som spesialiseringene øker, trengs mer koordinering og ledelse. Som vi har sett, har kirken søkt å klargjøre det innbyrdes forholdet mellom aktørene og deres mandat. Dette er en historie om mange spenninger.

\section{Referanser}

Aarflot, A. (1990). La kirken vore kirke. Cappelen.

Asheim, I. (1988). Kirken og samfunnet. Kirken og staten. Halvårsskrift for Praktisk Teologi, (1), 3-14.

Askeland, H. (1998). Ledere og lederroller. Om ledelse og lederroller i den lokale kirke. Tapir.

Askeland, H. (2000a). Drivkrefter i formingen av kirkelig organisering. Tidsskrift for Kirke, Religion, Samfunn, 13(1), 51-61.

Askeland, H. (20oob). Reform av den lokale kirke. Kontekst, prosess, utfall. Tapir.

Askeland, H. (2015). Reforming the pastoral leadership structure in Church of Norway. Exploring whether and how the managerial role of the dean has been strengthened. I H. Askeland \& U. Schmidt (Red.), Church reform and leadership of change (s. 92-116). Pickwick Publications.

Askeland, H., Grimstad, F. \& Riise, K. Y. (1998). Lederroller i den lokale kirke: Fellesrapport fra tre spørreundersøkelser. KA Kirkens arbeidsgiverorganisasjon.

Askeland, H. \& Schmidt, U. (Red.). (2016). Church reform and leadership of change. Pickwick Publications.

Baasland, E. (1993). Ledelsesstrukturer i den eldste kirke. I P. O. Gullaksen, T. Austad, E. Fougner \& O. Skarsaune (Red.), Reform og embete. Festskrift til Andreas Aarflot på 65-årsdagen den 1. juli 1993 (s. 181-198). Universitetsforlaget.

Birkedal, E. (2017). Frivillighet i trosopplæringen. En refleksjon om samspill mellom ansatte og frivillige. Prismet, (3), 231-241. https://doi.org/10.5617/pri.5551

Blizzard, S. W. (1956). The minister's dilemma. Christian Century, 73, 508-510.

Bromley, P. \& Meyer, J. W. (2017). «They are all organizations»: The cultural roots of blurring between the nonprofit, business, and government sectors. Administration \& Society, 49(7), 939-966. https://doi.org/10.1177/0o95399714548268

Brunsson, N. \& Sahlin-Andersson, K. (2000). Constructing organizations: The example of public sector reform. Organization Studies, 21(4), 721-746. https://doi. org/10.1177/0170840600214003 
Bäckström, A. (1996). Kyrkligt ledarskap inför 200o-talet: Om prästens yrkesroll och religiöst ledarskap. Svenska Kyrkans Forskningsråd.

Bäckström, A., Beckman, N. E. \& Pettersson, P. (2004). Religiös förändring i norra Europa. En studie av Sverige: «Från statskyrka till fri folkkyrka». Slutrapport.

Diakonivetenskapliga institutet. DiVA. http://urn.kb.se/resolve?urn=urn:nbn:se: uu:diva-19502

Carroll, J. W. \& McMillan, B. R. (2006). God's potter. Pastoral leadership and the shaping of congregations. William B. Eerdmans Publishing.

Elstad, H. (2005). Nyere norsk kristendomshistorie. Fagbokforlaget.

Fiske, M. (2017). Det er en kirkelig leder jeg er. Hvordan og på hvilken måte har kirkevergens lederrolle i Den norske kirke utviklet seg gjennom de siste tjue årene? [Masteroppgave, VID vitenskapelige høgskole]. VID Open. http://hdl.handle. net/11250/2452812

Furseth, I. (2015). Religionens tilbakekomst i offentligheten? Religion, politikk, medier, stat og sivilsamfunn i Norge siden 1980-tallet. Universitetsforlaget.

Grimstad, F. (1983). Samarbeid i menigheten. Kirkerådet.

Grimstad, F. (1990). Kirkens personalhåndbok. Kirkerådet.

Grimstad, F. (2005). Kirken - mellom hierarki og demokrati. I M. H. Hougsnæs (Red.), Den norske kirke - for folk flest. Aktuelle perspektiver på utviklingen av det kirkelige demokrati (s. 9-21). KA Kirkelig arbeidsgiver- og interesseorganisasjon.

Grimstad, F. (1999). Lekfolket i arbeidsgiverrollen. I M. H. Hougsnæs (Red.), Kirken, lekfolket og presteskapet. Kirkeliv og kirkereformer i Den norske kirke ved årtusenskiftet (s. 59-67). KA kirkellig arbeidsgiverorganisasjon

Grimstad, F. \& Askeland, H. (1999). Den lokale kirkes styrmenn og -kvinner. Sitter de ved roret? I M. H. Hougsnæs (Red.), Kirken, lekfolket og presteskapet. Kirkeliv og kirkereformer i Den norske kirke ved årtusenskiftet (s. 40-58). KA kirkelig arbeidsgiverorganisasjon.

Gullaksen, P.-O. (1993). Den nye kirken og den nye staten. Utviklingstrekk etter 1983. I P.-O. Gullaksen, T. Austad, E. Fougner \& O. Skarsaune (Red.), Reform og embete. Festskrift til Andreas Aarflot på 65-årsdagen 1. juli 1993 (s. 49-60).

Universitetsforlaget.

Gullaksen, P.-O., Austad, T., Fougner, E. \& Skarsaune, O. (Red.). (1993). Reform og embete. Festskrift til Andreas Aarflot på 65-årsdagen den 1. juli 1993.

Universitetsforlaget.

Hansen, T. (2016). Kommuneinndelingen - fra lokale økonomiske klubber til statlige velferdsprodusenter. I J. E. Klausen, J. Askim \& S. I. Vabo (Red.), Kommunereform i perspektiv (s. 47-69). Fagbokforlaget.

Hansson, P. \& Andersen, J. A. (2008). Vicars as managers revisited: A comparative study. Nordic Journal of Religion and Society, 21(1), 91-111. https://www.idunn.no/ file/ci/66930161/Vicars_As_Managers_Revisited_A_Comparative_Study.pdf 
Hegstad, H. (2009). Den virkelige kirke. Bidrag til ekklesiologien. Tapir.

Hougsnæs, M. H. (2005). Embete og råd - status etter Kirkemøtet 2004. I M. H. Hougsnæs (Red.), Den norske kirke - for folk flest (s. 31-42). KA Kirkelig arbeidsgiver- og interesseorganisasjon.

Huse, M. (1998). Prosten. Ansvar, arbeidssituation og ledelse. Tapir.

Huse, M. (2000). Prest og ledelse. Verbum.

Kirkeloven. (1996). Lov om Den norske kirke (LOV-1996-06-07-31)[Opphevet].

Lovdata. https://lovdata.no/pro/lov/1996-06-07-31

Kirkerådet. (1975). Embetsteologi og tjenestedifferensiering. Kirkerådet.

Kirkerådet. (1977/81). Tjenester og stillinger. Kirkerådet.

Kirkerådet. (1987). Kirkens embete og råd. Kirkerådet.

Kirke/stat-utvalget. (2001). Reformer i Den norske kirkes ordning 1984-98

(Delrapport, april). Kirkedepartementet. https://kirken.no/globalassets/kirken.no/ om-kirken/slik-styres-kirken/kirkeordningen/2002-2012/kirke_stat_utvalg_98_ O2_delrapport_reformer.pdf

Madeley, J. \& Enyedi, Z. (Red.). (2003). Church and state in contemporary Europe. The chimera of neutrality. Frank Cass.

Meyer, J. W. \& Bromley, P. (2013). The worldwide expansion of «organization». Sociological Theory, 31(4), 366-389. https://doi.org/10.1177/0735275113513264

Mjånes, Å. S. (2017). Kvar er seg sjølv noerast. Eit kvantitativt studie av prostar og kyrkeverjer sine leiarroller og legitimitet i Den norske kyrkja [Masteroppgave, VID vitenskapelige høgskole]. VID Open. http://hdl.handle.net/11250/2452752

NOU 1985: 21. (1985). Den norske kirken og loeren. Fremgangsmåten ved behandling av teologiske loerespørsmål i Den norske kirke. Kirke- og undervisningsdepartementet.

NOU 1989: 7. (1989). Den lokale kirkes ordning. Kirke- og undervisningsdepartementet.

Ot. prp. nr. 74 (1982-83). Om lov om endringer i lov av 29. april $1953 \mathrm{nr} .1$ om Den norske kirkes ordning $m$. $m$. Kirke- og undervisningsdepartementet.

Raustøl, T. (1993). Kirkelig selvstyre - i kommunen? Oppfølging av Kirkelovutvalget $i$ spenningsfeltet mellom kommunalt og kirkelig selvstyre. Kommuneforlaget.

Reformkommisjonen. (1969). Reform av Den norske kirke. Kirkedepartmentet.

Repstad, P. (2002). Dype, stille, sterke, milde. Religiøs makt i dagens Norge. Gyldendal.

Rødahl, G. (1988). Rådskirken tar form. Kirkerådet.

Røvik, K. A. (2012). Organisasjonsendring som korporativisering. Magma, 15(12), 49-58. https://www.magma.no/organisasjonsendring-somorganisasjonsgjoring

Saglie, J. \& Segaard, S. B. (2011). Den norske kirkes demokratiske legitimitet erfaringer fra kirkevalget 2009. Norsk Statsvitenskapelig Tidsskrift, 27(3), 155-178. https://www.idunn.no/nst/2011/03/arto3

Schmidt, U. (2011). Evaluering av demokratireformen i Den norske kirke. Sluttrapport (KIFO Notat 5/2011). Stiftelsen Kirkeforskning. http://www.kifo.no/wp-content/ uploads/2016/og/Sluttrapport-Evaluering-demokratireformen.pdf 
Seland, B. (2018). Bønder i opposisjon - politisk profil, organisatoriske linjer.

I B. Seland (Red.), Opprør og opposisjon under enevelde og demokrati (s. 95-130). Cappelen Damm Akademisk.

Sirris, S. (2013). Pastoral ledelse i praksis. En empirisk undersøkelse av forholdet mellom soknepresters utøvelse av ledelse og forståelse av egne lederroller.

[Masteroppgave, Diakonhjemmet høgskole]. VID Open. http://hdl.handle. net/11250/98523

Sirris, S. (2019a). Coherent identities and roles? Hybrid professional managers' prioritizing of coexisting institutional logics in differing contexts. Scandinavian Journal of Management, 35(4). https://doi.org/10.1016/j.scaman.2019.101063

Sirris, S. (2019b). Managers negotiating identities: Hybridizing professionalism and mangerialism in faith-based health organizations and in religious organizations [Doktorgradsavhandling, VID vitenskapelige høgskole]. VID Open. http://hdl. handle.net/11250/2632293

Skjevesland, O. (1994). Huset av levende steiner. En teologi for menighetsoppbygging. Verbum forlag.

St. meld. nr. 40 (1980-81). Om stat og kirke. Kirke- og undervisningsdepartementet.

Stifoss-Hanssen, H., Angell, O. H., Askeland, H., Schmidt, U., Urstad, S. \& Kinserdal, F. (2013). Ny organisering av prestetjenesten («Prostereformen»). Evaluering. Diakonhjemmet høgskole.

Ulstein, J. O. (2019). Kateketteneste og embetssyn - vigsling til kva? Prismet, (3), 187-198. https://doi.org/10.5617/pri.7141

Utredningskommisjonen. (1973). Den norske kirke og staten. Kirkerådet.

Voksø, P. (1993). Da reformlinjen seiret. I P. O. Gullaksen, T. Austad, E. Fougner \& O. Skarsaune (Red.), Reform og embete. Festskrift til Andreas Aarflot på 65-årsdagen den 1. juli 1993 (s. 39-48). Universitetsforlaget. 


\title{
KAPITTEL 4
}

\section{Forskningsperspektiver på kirke og menighet som organisasjon}

\author{
Harald Askeland
}

VID vitenskapelige høgskole

\begin{abstract}
Understanding churches as organizations inevitably means borrowing models and premises from organizational theory (OT). This chapter outlines the basic assumptions underlying dominant perspectives in OT, enhancing the possibility for an informed utilization and exploration of the commonalities and diversities between religious and other organizations. It provides a framework for differing clusters of theories and review of some major research contributions of ecclesial and congregational organizations within each theoretical perspective or cluster. Lastly, the chapter addresses how and in which direction further research of church organizations might be developed, pointing at institutional pluralism, hybrid organizations and institutional work as prospective avenues for further exploration.
\end{abstract}

Keywords: church, congregation, institutional, organization, research

\section{Introduksjon}

En viktig bieffekt av reformprosessen som over tid har ledet til selvstendiggjøring av Den norske kirke, er at kirken og dens menigheter fremstår som selvstendige rettssubjekter og i stor grad som organisasjoner. Dette kapitlet presenterer og drøfter ulike perspektiver for å forstå kirke og menighet som organisasjoner, samt drøfter sentrale modeller og begreper fra organisasjonsfaget. Kapitlet bidrar med viktige innsikter til forståelse, analyse og praktisk arbeid med menighetsorganisering, utvikling og ledelse.

Sitering av denne artikkelen: Askeland, H. (2021). Forskningsperspektiver på kirke og menighet som organisasjon. I S. Sirris \& H. Askeland (Red.), Kirkelig organisering og ledelse: Et verdibasert og praksisorientert perspektiv (Kap. 4, s. 83-105). Cappelen Damm Akademisk. https://doi.org/10.23865/noasp.129.ch4

Lisens: CC BY-NC-ND 4.0 
Forståelsen av kirkelig organisering, ledelse og endring i kirke og menighet låner implisitt ideer fra teorier om organisasjoner og ledelse av organisasjoner (Van Gelder, 2007). Når man låner perspektiver og teorier med forankring i samfunnsvitenskap, vil man også få med seg en del implisitte antakelser og handlingsmodeller på kjøpet. I arbeidet med å anvende organisasjons- og ledelsesfag i kirke og menighet er det nødvendig å kjenne de underliggende premisser og perspektiver i organisasjonsteori. En viktig hensikt med kapitlet er å bidra til å sortere mellom ulike organisasjonsteoriers premisser og grunnperspektiv. I stedet for å se teorimangfold som en frustrerende situasjon vil jeg argumentere for at en får ulike analytiske grep for å forstå en virkelighet med en mangfoldig institusjonell kontekst. De spørsmålsstillinger som tas opp i dette kapitlet, kan formuleres på følgende måte:

- Hvordan bidrar kunnskaps- og handlingsteorier til utviklingen av ulike perspektiver og modeller av organisasjon og ledelse?

- Hvilke konsekvenser har dette for forståelse av kirkelig organisering, ledelse og endring?

\section{Grunnleggende premisser for organisasjons- og ledelsesteorier}

I takt med økende selvstendiggjøring av Den norske kirke som trossamfunn og pågående endringsprosesser i kirken, blir organisering og ledelse et diskusjonstema. Ikke minst har det de seneste tiårene vært flere bidrag som tematiserer kirkelig organisering som et teologisk anliggende (Hegstad, 2009; Hougsnæs, 2004; Skjevesland, 1998). Tilsvarende har det i lengre tid vært arbeidet med dette spørsmålet fra et organisasjons- og ledelsesperspektiv (Askeland, 1996, 2000a; Hernes, 2002; Huse, 1998; Sirris, 2016; Stifoss-Hanssen et al., 2013).

Organisasjoner er et sentralt trekk ved vårt samfunn og utøver en betydelig innflytelse over våre liv (Perrow, 1991). Noen organisasjoner deltar vi i bare som kunder eller brukere, andre deltar vi i over lengre tid gjennom arbeid og organiserte fritidsinteresser. I tillegg er ivaretakelsen av de offentlige tjenester vi mottar og de beslutninger som angår oss, 
lagt til organisasjoner eller offentlige etater/byråkratier. Selv om vi ofte vil tenke på trossamfunn, menigheter og kristelige foreninger som fellesskap, vil de også kunne betraktes som organisasjoner (Askeland, 1996). Samtidig er det hevdet at det nettopp er reformprosesser som driver fram anvendelse av organisasjonsbegrepet, og at det ikke er gitt at begreper som forvaltning, byråkrati og trosfellesskap uten videre har alle kjennetegn for organisasjoner (Brunsson \& Sahlin-Andersson, 200o). Alternativt kan menigheter forstås som hybrider, altså blandingsformer mellom ulike organisasjonstyper (Yancey, 1986). De grunnleggende spørsmål om hva organisasjoner er, hvordan de fungerer, endres og ledes, blir det derfor viktig for valgte ledere og ansatte med ledende roller å ha et reflektert forhold til.

I den grad vi forutsetter at organisasjoner ikke fullt ut er objektive eller sansbare størrelser, må vi legge til grunn at det handler om begrepsmessig abstraksjon av gitte sett av sosiale relasjoner. Organisasjoner kan ses som en bestemt gruppe sosiale kollektiver, og kan dermed fruktbart sammenlignes med begreper om andre sosiale relasjonssett eller grupper.

Tabell 1. Begrepselementer i en organisasjonsdefinisjon (Martinussen, 1984, s. 54)

\begin{tabular}{|l|l|l|}
\hline Det som kan observeres & Betegnelse på sosial enhet & Eksempel på sosial enhet \\
\hline Gjentatt samhandling & & Samtale med bekjent \\
\hline Felles problemforståelse & Sosial relasjon & Vennskap, gjentatt samarbeid \\
\hline Avgrensning mot omgivelser & Sosialt system & Familie, arbeidsgruppe \\
\hline Strukturert samvirke mot mål & Organisasjon & Bedrift, etat, menighet \\
\hline
\end{tabular}

I denne presentasjonen, formulert av den norske sosiologen Willy Martinussen, kan vi legge merke til at sosial organisasjon som begrep innebærer at det skjer en fortetting mellom relasjonene, gjerne en slags formalisering og strukturering av dem. Fra sporadisk samhandling utvikles relasjoner til tettere samarbeid ved å identifisere felles utfordringer eller oppgaver, og om det også skjer en konkret avgrensning mot omgivelser med klare interne posisjoner omtales det som et sosialt system. Når det skjer en ytterligere forsterkning i formålsorientering eller oppgaveløsning, som krever koordinering av aktivitet samt en standardisering av aktuelle handlingsrepertoar, i form av organisatorisk rollefordeling og rolleatferd, snakker vi om en organisasjon. 
Ut fra ulike tilnærminger til organisasjoner følger også forskjellige definisjoner. I denne omgang vil det kun bli presentert en foreløpig definisjon, som bidrar til å avgrense feltet: «Med organisasjon vil vi oftest forstå en gruppe eller et kollektiv av individer som samhandler på en koordinert måte for å realisere bestemte mål eller oppgaver» (Askeland, 2013, s. 3).

Alle fag har et mer eller mindre tydelig definert kunnskapsgrunnlag. Slike faglige grunnposisjoner kan tilbakeføres til ulike vitenskapsteoretiske posisjoner (Ghoshal, 2005; Hollis, 2002). Ulike grunnposisjoner kan illustreres ved å anvende to sentrale dimensjoner: kunnskapsteori og handlingsteori (Hales, 2007; Kemmis, 2011; Vanebo, 2001).

En dimensjon handler om forståelsen av den sosiale virkeligheten vi er en del av (Askeland, 2016, s. 6). Kan den betraktes som objektiv realitet innebærer det at vi kan utforske og vinne sikker kunnskap. Om den derimot betraktes som subjektiv, og først framstår som «virkelig» ut fra vår fortolkning, er det vår egen konstruksjon av den sosiale virkelighet vi forholder oss til. Innen kunnskapsteorien vil det første synet bygge på positivismen, mens det andre vil bygge på subjektivismen som et grunnleggende perspektiv. Den første dimensjonen kan sies å handle om virkelighetsforståelse og rasjonalitetsform (Askeland, 2012). Noen av fagets bidragsytere vil dermed vektlegge at organisering og ledelse må følge av klare mål, samt en klar analyse og vurdering av hva som leder til effektiv måloppnåelse. Andre bidragsytere vil argumentere for at vi kan ha ulike erfaringer og interesser å ivareta, og at vi derfor fortolker og forhandler de mål og premisser som skal styre den organisatoriske praksis.

Tabell 2. Klassifisering av tradisjoner/perspektiver i organisasjons- og ledelsesteori (Askeland, 2012, s. 24)

\begin{tabular}{|l|l|l|}
\hline \multirow{2}{*}{$\begin{array}{l}\text { Handlingsteoretisk } \\
\text { dimensjon }\end{array}$} & \multicolumn{2}{|c|}{ Kunnskapsteoretisk dimensjon } \\
\cline { 2 - 3 } & $\begin{array}{l}\text { Positivistisk } \\
\text { Rasjonell }\end{array}$ & $\begin{array}{l}\text { Subjektivistisk } \\
\text { Fortolkende }\end{array}$ \\
\hline $\begin{array}{l}\text { Struktur } \\
\text { Kollektiv }\end{array}$ & System & Institusjon \\
\hline $\begin{array}{l}\text { Aktør } \\
\text { Individ }\end{array}$ & Instrument & Assosiasjon \\
\hline
\end{tabular}

Den andre viktige dimensjonen dreier seg om i hvilken grad man i studier og forklaringsmodeller tar utgangspunkt i overordnede strukturer eller 
individuelle vurderinger og behov, når individuell og kollektiv handling skal forstås og forklares (Askeland, 2016). Når utgangspunkt tas i strukturelle faktorer, omtaler en oftest organisasjoner som systemer. Dette innebærer at utgangspunktet for analyse og forklaring bygger på at organisasjonen er et etablert system som legger premissene for individers handling. Den etablerte struktur og rollefordeling angir hvordan og av hvem ulike funksjoner ivaretas. En aktørtilnærming derimot, ser organisasjoner som en samling av individer som ser det tjenlig å samarbeide om oppgaveløsning rundt spesifikke mål. Innen denne tilnærmingen omtaler en gjerne organisasjoner som assosiasjoner. Teorier med dette utgangspunktet baseres på en forstålse av organisasjon og ledelse der individer slutter seg sammen fordi kollektiv oppgaveløsning antas å være gunstig. Sammenfattende kan disse ulike tilnærmingene fremstilles i tabell 2.

Tabellen synliggjør hvordan anvendelse av disse to dimensjonene danner grunnlag for en idealtypisk kategorisering av fire paradigmer innen organisasjons- og ledelsesfaget, noe som utfoldes senere i kapitlet, der det argumenteres for at videre fagutvikling enten må kombinere eller se de ulike paradigmer i sammenheng. Valget av disse to sentrale dimensjonene, både til synliggjøring av ulike teorigrupperinger men også deres underliggende forutsetninger, bygger på ulike modeller av organisasjoner: system, instrument, assosiasjon og institusjon. Systemteoriene har struktur som viktig forklaringsfaktor og bygger på rasjonelle analyser, mens instrumentperspektivet er rasjonelt og ser organisasjoner som individuelle og autonome aktører. Institusjonelle teorier bygger på overordnede strukturelle forklaringer, men forutsetter fortolkning og meningsdanning. Assosiasjonsteorier vektlegger at individuelle aktører slutter seg til organisasjonen med basis i at de deler og samhandler rundt delte verdier og mening. Disse grupperingene vil bli utfoldet i neste seksjon.

\section{Relevans for forståelsen av kirke og menighet som organisasjon}

I det følgende vil jeg kort vise hvordan ulike perspektiver innebærer ulike grunnsyn på hvordan organisasjoner skal forstås og også legge føringer for forståelse av organisering, ledelse og endring. I tillegg integreres hvordan 
ulike faser i en «faghistorie» for kirkelig organisasjons- og ledelsesforskning har bygd på disse perspektivene. Mens det etter hvert har kommet flere faglige bidrag til ledelse, reform og utvikling i en kirkelig kontekst, er det langt færre som eksplisitt har tematisert kirkelige organisasjoner (Tracey, 2012). Dette er også situasjonen innen internasjonal forskning, der det imidlertid er en økende interesse for betydningen av og koblingen mellom religion, organisering og ledelse (Espedal, 2019; Pandey \& Varkkey, 2020; Purchase et al., 2018; Smets et al., 2020). Like fullt har det kommet bidrag som argumenterer for at religiøse organisasjoner i seg selv er et viktig forskningsfelt, fordi de representerer særegne case og også inngår i den helhet av organisasjoner som konstituerer fagets interessefelt (Tracey et al., 2014, s. 5). En generell trend er at bidragene over tid har forskjøvet seg fra et system- til et institusjonelt perspektiv, med enkelte bidrag fra assosiasjons- og instrumentperspektivet (Tracey, 2012).

\section{Organisasjoner som system}

I dette perspektivet anses organisasjonen som rasjonell og styrbar, men også som åpen og avhengig i sitt forhold til omgivelsene. Organisasjoner kan tilpasse seg strategisk, eller også søke å påvirke sine omgivelser i ønsket retning. Organisasjoner består av subsystemer som inngår i større systemer. Forholdet mellom disse undersystemene omtales ofte som løst koblede. Dette innebærer skiftende koalisjoner av interessegrupper som fastsetter mål ved forhandling, og der struktur, aktiviteter og utbytte i sterk grad avhenger av omgivelsene (Scott, 1987, s. 23). Bidrag som anvender dette perspektivet er opptatt av hvordan organisasjoner innretter seg rasjonelt $\mathrm{i}$ et forsøk på å tilpasse seg, mestre eller påvirke omgivelsene. Et sentralt poeng er at kilden til organisatorisk endring ligger i omgivelsene. En viktig side er nettopp at organisasjoner ses parallelt med andre organiske systemer som må tilpasse seg omgivelsene, og der likevekt eller stabilitet framstår som et implisitt mål.

Internasjonale studier av religiøse og trosbaserte organisasjoner faller ofte innen denne kategorien (Scherer, 1980). Et tidlig norskpublisert bidrag til å forstå kirken i et organisasjonsperspektiv, skrevet av sivilingeniøren Roar Mjelva, var også systemteoretisk (Mjelva, 1979), idet kirken 
ble ansett å være sammensatt av ulike subsystemer. Mjelvas bidrag er primært konseptuelt, og legger til grunn at de to store subsystemene er et sosialt og et religiøst subsystem. Kirken har også et regulerende element, omtalt som det administrative subsystem. Artikkelen utvikler resonnementer rundt forholdet mellom subsystemene, men har sitt viktigste bidrag i å utmeisle hvilke elementer som kan tenkes å inngå i det enkelte system og dermed gjøres til gjenstand for studium eller refleksjon. I en nordisk kontekst har flere publikasjoner trukket veksler på dette hovedperspektivet (Askeland, 1994; Omland \& Johannessen, 1998; Palmu, 1991). Min (Askeland, 1994) forskning omhandler analyse av en konkret menighet, med to teoretiske bidrag. For det første argumenterer jeg for at menigheten er et system i stadig danning, omdanning og gjendanning $i$ ulike former: Som folkekirkefellesskap, som et engere trosfellesskap og som et mer operativt arbeidsfellesskap. For det andre utvikles en modell der sentrale dimensjoner for å analysere menighetens organisatoriske form knyttes til oppgaver, struktur, medlemmer, arbeidsform og kultur, som opererer i kontekst. Den finske kirkeforskeren Harri Palmu omtaler til dels andre men nokså likeartede elementer for analyse av menighetssystemet: eksterne omgivelser, religiøse oppgaver samt menighetens identitet og mål (kultur i vid forstand) (Palmu, 1991, s. 12f).

Også mye internasjonal litteratur om endring og utvikling i kirke og menighet, blant annet i litteratur om menighetsutvikling, har systemmodellen som utgangspunkt (Ammerman, 1997; Van Gelder, 2007). Enkelte tidlige forfattere pekte på at systemteori klart lånte ideer fra biologi og organismetenkning, og at dette ville kunne passe godt med en kirkelig selvforståelse som Kristi legeme (Rudge, 1968, s. 43ff). Viktigere er likevel den vekt som legges på omgivelsene, nærmest med en kausal effekt på menigheters utvikling og overlevelse. Særlig den amerikanske teologen Craig Van Gelder er opptatt av at menighetene både kan og bør søke å strategisk påvirke eller utnytte aspekter ved omgivelsene (Van Gelder, 2007, s. 143).

Perspektivet har sin styrke $\mathrm{i}$ at det håndterer vekselvirkningen mellom interne subsystemer og de koblinger og den avhengighet som eksisterer overfor det eksterne miljø. Vekten på sammenhengen mellom system og subsystem passer også med kirkens desentraliserte struktur, med svak 
kobling både vertikalt og horisontalt. Svakheten med perspektivet er at de enkelte aktører lett kan drukne i analyser av systemets behov, samt at det ikke alltid klarer å fange opp den mulighet organisasjonen har til å påvirke og forme egne omgivelser. Strategisk endring handler i stor grad om tilpasning til eksterne betingelser.

\section{Organisasjoner som instrument}

I dette perspektivet ses organisasjoner som kollektiver av rasjonelle agenter ${ }^{1}$ orientert mot oppnåelse av relativt spesifikke mål, og er kjennetegnet av en formalisert struktur. Slik skiller organisasjoner seg fra andre kollektiver gjennom høy grad av hierarkisering, målorientering og formalisering. Dermed blir organisasjonen sett som et instrument for realisering av gitte mål (Askeland, 200ob). Samtidig vil dette perspektivet langt på vei betrakte omgivelsene som noe organisasjonen aktivt forholder seg til og søker å påvirke ut fra egne strategiske mål (Scott, 1987, s. 99).

En konsekvens av å se organisasjoner i dette perspektivet er at en ofte legger til grunn at endring skjer som følge av planlagt og kalkulert intervensjon i organisasjonen. Planlagt endring vil ofte antas å henge sammen med analyser og kunnskap om egen effektivitet, og der mekanismer klargjør når det er endringsbehov. Endring tilligger vanligvis styringsorgan og ledere, og tenkes ofte å være lederinitiert.

Med utgangspunkt i dette perspektivet er det gjennomført studier av endringer i prestetjenesten og utviklingen av prostens lederrolle (Huse, 1998), ut fra prinsipal-agent-teori. Et neo-rasjonelt perspektiv er anvendt i den svenske teologen Per Hanssons studier av endring innen den svenske kirken (Hansson, 1993). Sentralt i dette perspektivet er at det finnes en hovedmann (grunnlegger eller eier som opptrer som prinsipal) som har en klar intensjon med organisasjonen. Organisasjonen kan derfor ses som et instrument (agent) for måloppnåelse, og det er ansatt et profesjonelt lederskap for å realisere målene. I denne rammen kan trosbaserte organisasjoner, som f.eks. kirke og menighet, beskrives som regulerte

1 Agentbetegnelsen tilkjennegir nettopp en formålsrasjonell og bytteorientert teoretisk modell av individer, som trekker veksler blant annet på mikroøkonomisk teori. 
og desentraliserte. Dette siste gjelder særlig dersom organisasjonen har regionale og lokale ledd med en varierende grad av autonomi. Et viktig aspekt ved tilnærmingen er å sikre styrbarhet i kirkeorganisasjonen, gitt den desentrale oppbyggingen. Særlig er det prestetjenesten og de sentrale kirkelige råd som, gjennom innveving i det statlige mål- og resultatstyringsverktøyet, er preget av den hierarkiske styrings- og ledelsestenkning som springer ut av New Public Management (NPM) (Askeland, 2000a). Dette er betegnelsen på et sett av forvaltningsreformer som utviklet seg internasjonalt fra midt på 1980-tallet med sterk vekt på markedsløsninger, bedre organisering og tydeliggjøring av styrings- og ledelseslinjer (Hood, 1991).

Det siste tiåret har vi også sett en tiltakende interesse blant økonomer for å analysere religiøse organisasjoner, f.eks. kirker og menigheter, innen rammen av økonomisk organisasjonsteori - og for så vidt også innen religionssosiologien. Blant annet har man analysert markedslogikk for å forstå effekten av henholdsvis statskirkelige samfunn og samfunn der religion er deregulert med hensyn til religiøst engasjement (Iannaccone et al., 1997). Det er pekt på at dette perspektivet i liten grad har lagt vekt på organisering og ledelse (Iyer, 2016). Unntaket er feltet strategisk ledelse, der det pekes på at religiøse organisasjoner vil kunne vinne markedsfordeler ved troverdighet og sosial legitimitet, men også ved å bygge politiske allianser (Miller, 2002).

\section{Organisasjoner som assosiasjon}

Ut fra et naturlig systemperspektiv ses organisasjoner først og fremst som kollektiver der aktører deler en felles interesse i systemets overlevelse og der de engasjeres i kollektiv, uformelt strukturert aktivitet for å oppnå dette målet (Scott, 1987, s. 23). ${ }^{2}$ Analyser av organisasjoner innen dette perspektivet legger vekt på det indre liv og interne arrangementer i organisasjonen. Det finnes noen aktuelle studier som naturlig faller i denne kategorien, og et av de viktigste bidrag er gitt av den britiske forskeren

2 Her anvendes aktørbegrepet nettopp for å introdusere intensjon, mening og verdi som en motsats til det formålsrasjonelt orienterte agentbegrepet. 
Margaret Harris som klart knytter an til «non-profit associations» eller «voluntary associations» som teoretisk perspektiv (Harris, 1998). Hennes studie omfatter både kristne og jødiske forsamlinger og anvender assosiasjonen som modell: «Voluntary associations are groupings which offer the chance to come together with others to create or participate for collective benefit. [...] They are characterized by their common purpose of defending and promoting functionally defined interests» (Harris, 1998, s. 607).

Deltakelse er grunnleggende frivillig, og medlemmer forventer at deres materielle, sosiale eller psykologiske fordeler ivaretas. Det finnes dermed få eller svake formelle styringsmekanismer. Organisasjonen er ikke spesielt oppgaveorientert, og medlemmer søker i større grad ekspressivt sosialt og personlig utbytte av deltakelse - som fellesskap, støtte og mening. Relasjonen mellom frivillige medlemmer og ansatt stab kan være både uklar og spenningsfylt. Spenning kan knyttes til bredere medlemsgrupperinger i forhold til valgt og ansatt ledelse, som gjerne ut fra mandat og ansvar er mer oppgave- og endringsorientert (Harris, 1995). I tillegg kan en tiltakende profesjonalisering av ansatte bidra til passivisering og fremmedgjøring av de frivillige medlemmene (Harris, 1998, s. 608). Underliggende religiøse verdier synes å spille en sentral rolle i mange av de problemkomplekser som er rapportert i forskning, både med hensyn til ideologi, relasjoner og autoritet. Forslag om endring vil derfor lett kunne ideologiseres, og må kontinuerlig avveies mot verdigrunnlag.

Denne tradisjonen vil kunne bidra også med innsikter fra forskningen om relasjonen mellom lokale og sentrale ledd i frivillighetsorganisasjoner, gjennom kommunikasjon, nettverksbygging og samarbeid (Sirris, 2015). I tillegg har en del forskning rundt frivillighet og trosbaserte organisasjoner generert analyser omkring avhengighet av offentlig finansiering, som berører både interne relasjoner, virksomhetsendring og likedanning mellom frivillige og offentlige organisasjoner (Benson \& Dorsett, 1981). Styrken i dette perspektivet er at fokus, analyse og forklaring av organisasjoner inkluderer et klart aktørperspektiv. Svakheten kan tilsvarende være at det ikke i tilstrekkelig grad tematiserer hvordan organisasjonen er vevd inn i premisser og organisatoriske former og praksiser som preger det omkringliggende samfunn. 


\section{Organisasjoner som institusjon}

Dette perspektivet beholder erkjennelsen av organisasjoner som systemer som er åpne mot og i sterk grad påvirkes av sin samhandling med omgivelsene. Men det skjer en dreining i den forstand at det rasjonelle perspektivet utfordres og erstattes med sterkere vekt på uformelle sider, verdier og kultur. I det ligger at organisasjoner ses som sammensatt av tenkende og handlende aktører, og blir slik produkter av det individene i organisasjonen tenker og gjør. På den andre siden utgjør organisasjonen rammen som preger tenkning og handling hos organisasjonsmedlemmene.

Perspektivet legger også vekt på omgivelsene til organisasjonen, noe som er formulert i teorier om økologiske populasjoner eller i teorier om organisatoriske felt eller sektorer. I en studie av sammenhengen mellom menighet og lokalsamfunn har den amerikanske religionssosiologen Nancy Ammerman påpekt at økologiske perspektiver bidrar til tolkning av menighetsmessig endring: «As with any ecology, new life forms are constantly emerging, as old ones fade from the scene» (Ammerman, 1997, s. 346). Samtidig vektlegger hun at menigheten er en del av lokalsamfunnets institusjonelle infrastruktur, noe som innebærer at de er aktive og dynamiske nettverk av mening og virksomhet, konstruert av individuelle og kollektive aktører som befolker og vedlikeholder dem. Slik blir det naturlige perspektiv synlig, i motsetning til det mer rasjonelt orienterte systemperspektivet. Ammerman synes å ha gitt impulser til at menigheters strategi må baseres på en nøktern og allsidig situasjonsbeskrivelse (Hegstad, 2007).

Analyser av kirke og menighet innenfor rammen av dette perspektivet vil kunne trekke veksler på nyere teorier om institusjoner (Tracey et al., 2014). Perspektivet peker på sentrale prosesser som er vesentlige for å forstå organisasjoner. På den ene siden poengteres det at organisasjoner over tid, gjennom etablering av faste rutiner og handlemåter, nærmest utvikler en særegen kultur og identitet (Askeland, 2020; Selznick, 1957; Tracey, 2012). På den andre siden vektlegges det hvordan det i ulike faser eksisterer oppskrifter for hva som er god organisering innenfor bestemte organisatoriske felt, og at slike oppskrifter overføres mellom organisasjoner og sektorer bidrar til likedanning mellom organisasjoner (Røvik, 1998). Når det gjelder kirkelig organisering er perspektivet blitt anvendt 
for å forklare reformene på regionalt og sentralt nivå i Den norske kirke, ved å sammenligne dem med de generelle forvaltningsreformer som har funnet sted innen offentlig sektor (Askeland, 20ooa; Askeland \& Schmidt, 2015). Nyere utviklingstrekk ved perspektivet har vært anvendt for å studere hvordan kirkelig virksomhet preges av konkurrerende logikker, og hvordan aktører forhandler og utvikler hybride løsninger (Sirris, 2019a; Sirris \& Byrkjeflot, 2019).

Ledere av kirkelige organisasjoner er situert i en kontekst preget av ulike rasjonaliteter eller logikker. Eksisterende studier peker på at kirkelige ledere har integrert disse ulike rasjonalitetene i en helhetlig forståelse av virksomhetens formål og egen lederrolle. Sirris (2019a; 2019b) og Askeland (2015) viser at dette har skjedd i ulik grad blant proster. Gjennom prostereformen, initiert i 2004, har proster blitt tillagt et tydeligere mandat som ledere av prestetjenesten. Mange proster har fremdeles en primær rolleidentitet som prester, selv om de fullt ut aksepterer ansvaret som ligger til lederrollen (Sirris, 2019a). Flere studier peker på at kirkevergene gir uttrykk for en rolleforståelse som i større grad synes å innebære en helhetlig forståelse av ansvar og oppgaveportefølje som inngår i lederrollen (Askeland, 2016; Myrvang, 2020).

\section{Status og retning for videre fagutvikling}

Den foregående kategorisering og presentasjon av ulike bidrag sikter primært mot å skape en bevissthet om at valg av teori ikke er nøytralt. I tillegg til å styre hva vi studerer og påvirke våre forklaringsformer, gjennom ulike grunnleggende premisser, innbyr teoriene også implisitt til ulik modelltenkning om kirke og menighet som organisasjon. Det gis altså ulike metaforer eller modeller av organisasjoner med ulike fagtradisjoner og ulikt premissgrunnlag. For videreutvikling av studier, praktisk organisering og ledelse av endring er det viktig å ha bevissthet om de premisser en tar med seg gjennom valg av teoretisk tilnærming. Mangel på bevissthet kan forklare hvordan ulike debatter ikke fører fram fordi premissgrunnlaget er forskjellig, eller hvordan valg av teorier og modeller anvendes i forsøket på å bygge og utvikle kirke og menighet som organisasjon. I den grad slike underliggende modeller bidrar til å 
forme oppmerksomhet og handlingsvalg, vil det være nødvendig å være bevisst den posisjon man i utgangspunktet har - både for å forstå organisering, endring og ledelse, men også for den praktiske tilrettelegging av utviklingsprosesser.

Når menigheten skal forstås som kollektiv, synes det å være en god del sammenfall mellom organisasjonsteori og ekklesiologi langs de tidligere skisserte dimensjoner (se kapittel 2). Dette har implikasjoner for reformer, nyorganisering og ledelse i kirke og menighet. Derfor er det nyttig å avklare om en arbeider ut fra en rasjonell (objektivistisk) eller fortolkende (subjektivistisk) tilnærming i problembeskrivelser og ved skissering av løsningsalternativer. Tilsvarende vil det virke styrende hvorvidt man ser Den norske kirke som et helhetlig system som koordineres ovenfra (nasjonalt), eller om en ser på hvordan lokale enheter er fellesskap med selvstendig ansvar som avgir mandat til regionale og sentrale instanser. Alternativt kan det handle om hvorvidt man betrakter utviklingsprosessen som en strategisk tilpasning til endrede omgivelser som styres av ledelsen (systemmodell), eller om en ser det som aktørers intensjonelle vurdering av situasjon og muligheter med krav til bredere medvirkning (assosiasjonsmodell).

Mye av faglitteraturen, og også den praktiske styring og organisering som kirken er blitt del av de siste tiårene, forutsetter at organisering og ledelse må følge av klare mål og en klar analyse av hva som fremmer effektiv måloppnåelse. Samtidig er det en økende vekt på institusjonelle perspektiver, der en også ser organisasjoner som innvevd i plurale kontekster. Organisasjoner med sterk ideologisk identitet vil kunne være opptatt av at man kan ha ulike interesser og verdier å ivareta, og derfor forhandler og reforhandler hvilke mål og premisser den organisatoriske praksis skal være styrt ut fra. Dette kan også følge av at kirke og menighet er forankret i og utøver sin virksomhet i et pluralistisk institusjonelt miljø. Slik kan kirkelige organisasjoner sies å leve i skjæringspunktet mellom ulike handlingsrasjonaliteter som hver for seg må imøtekommes og realiseres gjennom ulike handlingsrepertoarer (Kraatz, 2009). I sin enkleste form ble dette beskrevet av Rø sin studie av kirken som arbeidsorganisasjon, der troskonteksten møtte arbeidslivskonteksten og hvor ulike kirkelige medarbeidergrupper kunne ha sterkere tilknytning 
til den ene eller andre av disse (Rø, 1985). Tilsvarende er prosessen med innføring av tidsregistrering for prester, blitt studert og fortolket i lys av å være ulike logikker som støter an mot hverandre, og der ledere ivaretar konseptuelt arbeid for å håndtere de spenningene som oppstår (Sirris, 2019b). En følge av å introdusere alternative og dels konkurrerende perspektiver og modeller handler også om å utvikle konseptuell modellrikdom, dels som evne til å se organisasjonen fra ulike synsvinkler, men også som kapasitet til å fortolke ulike synssett og overskride/syntetisere ulike handlingsrasjonaliteter og -repertoar. I det følgende vil jeg peke på tre begreper som hver på sin måte bidrar til å holde sammen alternative og eventuelt konkurrerende forventninger og rasjonaliteter: multistandardorganisasjoner, hybride organisasjoner og institusjonelt arbeid.

\section{Multistandardorganisasjoner}

Ideen om multistandardorganisasjon er utviklet av statsviter og organisasjonsforsker Kjell Arne Røvik (1998) og introdusert i en kirkelig kontekst av teologen Marit Halvorsen Hougsnæs (2012). Dette betegner en organisasjon som over tid har adoptert mange populære organisasjonsoppskrifter mht. organisering og bestemte praksiser. På et gitt tidspunkt vil dette kunne framstå som en løs kolleksjon av mange komponenter og institusjonaliserte standarder som er fanget opp av ulike aktører til ulike tider (Røvik, 1998, s. 282). Multistandardbetegnelsen handler både om at mange ulike former og institusjonaliserte standarder eksisterer, men også at organisasjonen evner å håndtere og veksle mellom disse (Hougsnæs, 2012, s. 19). Dette fordrer at organisasjonen har inntakskapasitet, dvs. evne til å fange opp og absorbere nye organisasjonsformer og praksiser. For å sikre at nye former og praksiser hverken overfortolkes eller bagatelliseres, kreves dekoplingskapasitet - en relevant implementering av nye elementer ut fra hva de er egnet til og i hvilke enheter og prosesser de kan være nyttige. Dekopling handler om evne til å implementere nye ideer, noen ganger på en tilsynelatende måte, uten at de direkte endrer eksisterende kjerneprosesser (Meyer \& Rowan, 1977). Ved dekopling kan organisasjonen som helhet imøtekomme ulike logikker eller handlingsforventninger fra ulike deler av konteksten. For å lykkes med dette 
trenger organisasjonen også en oversettelseskapasitet, slik at ideer og nye former oversettes og gjøres relevante og legitime i egen organisasjon. Nye organisasjonsformer og praksiser krever også kapasitet til lagring og reaktivering, i form av erfaringer, rutiner og begreper som forblir i organisasjonen. En siste viktig side ved multistandardorganisasjonen er at den også har høy uttakskapasitet, gjennom evne til å legge fra seg former og konsepter etter at man har oversatt og tatt til seg den relevante innsikt som nyvinningen har gitt. Hougsnæs argumenter for at en styrke ved disse organisasjonene ligger i evnen til å møte ulike kontekster parallelt, og at dette særlig er en utfordring til ledelse. Det handler dels om ressurser til å forholde seg aktivt til impulser i konteksten og evne til å bearbeide disse impulsene. Dels handler det om forståelse både av utvikling i omgivelser og sammenhenger organisasjonen forholder seg til, relatert til kapasitet og nytte i de ulike deler av egen organisasjon (Hougsnæs, 2012, s. 23).

\section{Hybride organisasjoner}

Ideen om hybride organisasjoner har klare paralleller til Røviks begrep, og antas gjerne også å være en respons på ulike konkurrerende logikker organisasjoner må forholde seg til (Billis, 2010). Organisasjoner kan omtales som hybride når de er konstituert i eller har et dobbelt oppdrag på tvers av sektorer. Selv om det er flere ulike bidrag til forståelsen av hva hybride organisasjoner er (Billis, 2010), legges det vanligvis til grunn at de oppviser en miks eller integrasjon av ulike formelementer, verdier eller rasjonaliteter fra en eller flere sektorer (offentlig, sivilsamfunn eller marked) (Jäger \& Schröer, 2014, Sirris 2019b; Karré 2020). Med hybridisering menes at nevnte elementer, ideer eller logikker smeltes om og blir til noe nytt som er forskjellig fra det som var tidligere (se kapittel 1).

Ofte vil utgangspunktet være at hybride organisasjoner eksisterer i skjæringspunktet mellom ulike samfunnssektorer eller dominerende rasjonalitetsformer, som for eksempel markedet, staten og det sivile samfunn (Billis, 2010; Evers, 2005). I konseptualisering av disse relasjonene former disse tre sektorene et triangel der hybride organisasjoner kan gjenfinnes i et overlappende felt mellom sektorene (Askeland, 
2016). Organisasjoner vil, basert på hva som er deres formål og faglige kjernevirksomhet, kunne danne ulike kombinasjoner av organisasjonsog praksisformer, med trekk fra ulike rasjonaliteter som kjennetegner sektorene. Om kirke og menighet forstås som institusjonaliserte organisasjoner, vil de kunne sies å være forankret i flere sektorer og låne trekk fra disse. Dels vil menigheter kunne antas å tilhøre sivilsamfunnet, men med klare trekk fra offentlig sektor. Dette skyldes delvis den historiske statskirkeformen, men også at de samhandler og samskaper innen rammen av kontakt og tilskudd fra lokale offentlige virksomheter. Samtidig kan det hevdes at reformer i offentlig sektor de seneste tiår har introdusert elementer fra en markedsbasert tilnærming som angir mulig integrasjon av rasjonaliteter, premisser og virkemidler på tvers av samfunnssektorer.

\section{Institusjonelt arbeid}

Institusjonell teori har vært ett av flere dominerende perspektiver innen organisasjons- og ledelsesforskning (Lawrence et al., 2009; Scott, 1995), der hovedintensjonen har ligget på hvordan institusjonen former aktører og likedannede organisasjoner (DiMaggio \& Powell, 1991; Meyer \& Rowan, 1991). Dette har vært sett som en kritisk svakhet, og ledet til interesse for å studere hvordan aktører bidrar intensjonelt og strategisk til å påvirke forming og utvikling av institusjoner og institusjonalisert praksis. Et sentralt bidrag i en slik nyorientering er institusjonelt arbeid, som har vokst fram som perspektiv siden begynnelsen av 2000-tallet: «the purposive action of individuals and organizations aimed at creating, maintaining and disrupting institutions» (Lawrence \& Suddaby, 2006, s. 215). Styrken ved denne formuleringen er at den introduserer både aktører, intensjonalitet og det syn at aktiviteten som utføres må ses som arbeid. I sitt originale arbeid skisserer forfatterne ulike typer «arbeid» eller praksiser som kan inngå i forsøk på henholdsvis å skape, vedlikeholde og endre institusjoner. Tidligere arbeid har framhevet betydningen av verdier i organisasjoners ulike faser (Maierhofer et al., 2003), men i mindre grad det arbeid som gjøres av aktører eller ledere der verdienes betydning gjøres gjeldende for institusjonelle formål. 
Innenfor denne rammen er det utviklet en rekke undertyper, deriblant identitetsarbeid, verdiarbeid, strategisk arbeid osv. (Lawrence et al., 2013, s. 1024). For en videreutvikling av formålet med å forstå organisering, reform og ledelse i kirken er det av særlig interesse å se nærmere på det som i ulike varianter omtales som verdiarbeid (Askeland et al., 2020; Gehman et al., 2013), strategisk arbeid med verdier for endring (Struminska-Kutra \& Askeland, 2020; Vaccaro \& Palazzo, 2014) eller hvordan ledere bidrar til verdier og identitet i organisasjoner (Askeland, 2014; Aadland et al., 2006). Lederes arbeid kan fruktbart integreres i perspektivet og forstås som institusjonell ledelse, som i særlig grad synes fruktbart for å forstå religiøse eller trosbaserte organisasjoner (da Silva, 2020). Institusjonell ledelse utvikles videre som et kjennetegn på kirkelig ledelse i kapittel 8 i denne boken.

Kirken og dens menigheter konstitueres som sosiale kollektiver langs grenseflaten av ulike institusjonelle sfærer. De konstitueres av sin opprinnelse i en religiøs sfære, og er i sin institusjonelle form preget både av lokalsamfunnet som kontekst og av at statskirken har hatt staten som lovgiver og styringsorgan. En slik posisjon, i skjæringspunktet mellom samfunnssektorer, kan utfordre på ulike måter. For eksempel kan det eksistere ulike forventninger til kirkens besluttende organer og ledere fra ulike aktører, både med hensyn til normative spørsmål og til hvilke organisasjonsformer som synes tjenlige.

\section{Konklusjon}

Kapitlet har argumentert for hvordan kunnskaps- og handlingsteorier former ulike perspektiver og modeller av organisasjon og ledelse. Dette betyr at anvendelse av organisasjonsteorier aldri er nøytral, og en bør være bevisst de underliggende premisser som følger med teorier. Slik vil det være mulig, gjennom kritisk gjennomgang og selvstendige empiriske studier, å kontekstualisere teorier til kirke og menighet. Selv om fremstillingen i artikkelen er en forenkling, kan det gi en referanseramme for å vurdere ulike modeller som anvendes i kirkelige organiseringsdebatter og -praksis. Selv om det er gjort få studier av kirke og menighet som organisasjon, skjer det stadig noe nytt på dette feltet. Dette representerer 
skritt fremover, der empirisk forskning bidrar til utviklingen av teoriperspektiver på kirkelig endring og ledelse.

Artikkelen argumenterer for at innsikt i organisasjonsfaget har noe å bidra med i kirken, og det henger sammen med to hovedfaktorer. For det første er organisasjonssosiologi et fag som utvikles ved at analyser gjøres av stadig nye virksomheter. For kirkens del vil det være nødvendig å ta i bruk en faglig tilnærming som gir den en mulighet til å forstå sin sosiale fremtredelsesform - både som et komplementært bilde til teologien, som kritisk selvvurdering og ikke minst som en plattform for å forstå den organisasjon en skal være leder i. Det gjennomføres også flere empiriske studier med basis i teologifagets empiriske vending, og dette vil på sikt kunne muliggjøre en konstruktiv dialog og ytterligere kontekstualisering av en kirkelig relevant organisasjonsteori.

En viktig innsikt som organisasjonsteori gir, handler om å øke den modellrikdom som ledere er avhengige av når komplekse spørsmålsstillinger skal avveies. Om den kirkelige organisasjon kun reduseres til et instrument for målrealisering, der en enkelt kan reorganisere kirken som om den er et alminnelig bedriftskonsern, vil man lett oppdage at organisatoriske strukturer og praksiser gjennom institusjonalisering tillegges større vekt og yter motstand mot endring. Erkjennelsen av at strukturer og praksiser institusjonaliseres, fordrer både en bredere og mer dyptgående tilnærming til endring.

\section{Referanser}

Aadland, E., Askeland, H., Flatebø, E., Haugen, H., Kaasa, A. \& Stapnes, L. M.

(2006). Verdibasert ledelse i praksis: En studie av 8 medlemsvirksomheter $i$ HSH.

Handels- og servicenæringens hovedorganisasjon.

Ammerman, N. T. (1997). Congregation and community. Rutgers University Press. Askeland, H. (1994). Menigheten som organisasjon. Tidsskrift for Kirke, Religion,

Samfunn, $7(1), 42-57$.

Askeland, H. (1996). Organisasjonsfaglig tilnærming til den lokale kirke. Tidsskrift for Kirke, Religion, Samfunn, 9(1), 47-65.

Askeland, H. (2000a). Drivkrefter i formingen av kirkelig organisering. Tidsskrift for Kirke, Religion, Samfunn, 13(1), 51-61.

Askeland, H. (200ob). Reform av den lokale kirke: Kontekst, prosess, utfall. Tapir. 
Askeland, H. (2012). Introduksjon til organisering og ledelse i diakonale organisasjoner. I E. Aadland (Red.), Ledelse i diakonale virksomheter (s. 17-37). Akademika forlag.

Askeland, H. (2013). Hvordan forstå organisasjoner og ledelse av organisasjoner (Rapport 2013:10). Diakonhjemmet Høgskole.

Askeland, H. (2014). Leaders should be the carriers of institutional values: An account of how leaders contribute to the value-base of diaconal institutions. Diaconia, 5(2), 149-177. https://doi.org/10.13109/diac.2014.5.2.149

Askeland, H. (2015). Reforming the pastoral leadership structure in Church of Norway: Exploring whether and how the managerial role of the dean has been strengthened. I H. Askeland \& U. Schmidt (Red.), Church reform and leadership of change. Pickwick Publications.

Askeland, H. (2016). Ledelse og lederes rolle i Den norske kirke:

Lederrolleundersøkelsen 2016 i et tyveårsperspektiv. Tidsskrift for Praktisk Teologi, 33(2), 5-19. https://journals.mf.no/tpt/article/view/5197

Askeland, H. (2020). Institutional leadership: Maintaining and developing the «good» organisation. I H. Askeland, G. Espedal, B. J. Løvaas \& S. Sirris (Red.), Understanding values work: Institutional perspectives in organizations and leadership (s. 139-158).

Palgrave Macmillan. https://doi.org/10.1007/978-3-030-37748-9

Askeland, H., Espedal, G., Løvaas, B. J. \& Sirris, S. (2020). Understanding values work: Institutional perspectives in organizations and leadership. Palgrave Macmillan. https://doi.org/10.1007/978-3-030-37748-9

Askeland, H. \& Schmidt, U. (Red.). (2015). Church reform and leadership of change (Bd. 12). Pickwick Publications.

Benson, J. K. \& Dorsett, J. H. (1971). Toward a theory of religious organizations. Journal for the Scientific Study of Religion, 138-151.

Billis, D. (2010). Hybrid organizations and the third sector: Challenges for practice, theory and policy. Palgrave Macmillan.

Brunsson, N. \& Sahlin-Andersson, K. (200o). Constructing organizations: The example of public sector reform. Organization Studies, 21(4), 721-746. https://doi. org/10.1177/0170840600214003

da Silva, J. B. (2020). Institutional leadership - the historical case study of a religious organisation. I H. Askeland, G. Espedal, B. J. Løvaas \& S. Sirris (Red.), Understanding values work: Institutional perspectives in organizations and leadership (s. 81-95). Palgrave Macmillan. https://doi.org/10.1007/978-3-03037748-9

DiMaggio, P. J. \& Powell, W. W. (1991). The iron cage revisited: Institutional isomorphism and collective rationality on organizational fields. I P. J. DiMaggio \& W. W. Powell (Red.), The new institutionalism in organizational analysis (s. 63-82). University of Chicago Press. 
Espedal, G. (2019). Being compassionate. Institutionalizing through values work in a faith-based organization [Doktorgradsavhandling, VID vitenskapelige høgskole]. VID Open. http://hdl.handle.net/11250/2633029

Evers, A. (2005). Mixed welfare systems and hybrid organizations: Changes in the governance and provision of social services. International Journal of Public Administration, 28(9-10), 737-748. https://doi.org/10.1081/PAD-200067318

Gehman, J., Trevino, L. K. \& Garud, R. (2013). Values work: A process study of the emergence and performance of organizational values practices. Academy of Management Journal, 56(1), 84-112. https://doi.org/10.5465/amj.2010.0628

Ghoshal, S. (2005). Bad management theories are destroying good management practices. Academy of Management Learning \& Education, 4(1), 75-91. https://doi. org/10.5465/amle.2005.16132558

Hales, C. (2007). Structural contradiction and sense-making in the first-line manager role. Irish Journal of Management, 28(1), 147-179.

Hansson, P. H. (1993). Steering and culture. Journal of Empirical Theology, 6(1), 77-92. https://doi.org/10.1163/157092593Xooo63

Harris, M. (1995). The organization of religious congregations: Tackling the issues. Nonprofit Management \& Leadership, 5(3), 261-274. https://doi.org/10.1002/nml. 4130050305

Harris, M. (1998). Organising God's work: Challenges for churches and synagogues. Palgrave Macmillan.

Hegstad, H. (2007). Menighetsutvikling på amerikansk. Halvårsskrift for Praktisk Teologi, 24(2). https://journals.mf.no/tpt/article/view/5054

Hegstad, H. (2009). Den virkelige kirke: Bidrag til ekklesiologien. Tapir akademisk.

Hernes, H. (2002). Folket og hyrdene: Et program for levende menigheter. Genesis.

Hollis, M. (2002). The philosophy of social science: An introduction (Rev. utg.). Cambridge University Press.

Hood, C. (1991). A public management for all seasons? Public Administration, 69(1), 3-19. https://doi.org/10.1111/j.1467-9299.1991.tboo779.xhttps://doi.org/10.1111/ j.1467-9299.1991.tboo779.x

Hougsnæs, M. H. (2004). Kirkesyn og kirkeledelse. Halvårsskrift for Praktisk Teologi, $21(2), 15-24$.

Hougsnæs, M. H. (2012). Med kirken som ledelseskontekst: Lederutfordringer i en multistandardorganisasjon. Tidsskrift for Praktisk Teologi, 29(2). https://journals. $\mathrm{mf} . \mathrm{no} / \mathrm{tpt} / \mathrm{article} / \mathrm{view} / 5122$

Huse, M. (1998). Prosten. Ansvar, arbeidssituation og ledelse. Tapir.

Iannaccone, L. R., Finke, R. \& Stark, R. (1997). Deregulating religion: The economics of church and state. Economic Inquiry, 35(2), 350-364. https://doi.org/10.1111/ j.1465-7295.1997.tbo1915.x 
Iyer, S. (2016). The new economics of religion. Journal of Economic Literature, 54(2), 395-441. https://doi.org/10.1257/jel.54.2.395

Jäger, U. P. \& Schröer, A. (2014). Integrated organizational identity: A definition of hybrid organizations and a research agenda. VOLUNTAS: International Journal of Voluntary and Nonprofit Organizations, 25(5), 1281-1306. https://link.springer. com/article/10.1007\%2Fs11266-013-9386-1

Karré, P. M. (2020). hybrid organisations between state and market. I D. Billis \& C. Rochester (Red.), International Handbook of Hybrid Organizations (s. 31-47). Edward Elgar Publishing.

Kemmis, S. (2011). What is professional practice? Recognising and respecting diversity in understandings of practice. I C. Kanes (Red.), Elaborating professionalism. Studies in practice and theory. Springer.

Kraatz, M. S. (2009). Leadership as institutional work: A bridge to the other side. I T. B. Lawrence, R. Suddaby \& B. Leca (Red.), Institutional work: Actors and agency in institutional studies of organizations (s. 59-91). Cambridge University Press. https://doi.org/10.1017/CBO9780511596605

Lawrence, T. \& Suddaby, R. (2006). Institutions and institutional work. I S. R. Clegg, C. Hardy, T. Lawrence \& W. R. Nord (Red.), The SAGE handbook of organization studies (2. utg., s. 215-254). Sage.

Lawrence, T. B., Leca, B. \& Zilber, T. B. (2013). Institutional work: Current research, new directions and overlooked issues. Organization Studies, 34(8), 1023-1033. https://doi.org/10.1177/0170840613495305

Lawrence, T. B., Suddaby, R. \& Leca, B. (2009). Introduction: Theorizing and studying institutional work. I T. B. Lawrence, R. Suddaby \& B. Leca (Red.), Institutional work: Actors and agency in institutional studies of organizations (s. 1-28). Cambridge University Press. https://doi.org/10.1017/CBO9780511596605

Maierhofer, N. I., Rafferty, A. E. \& Kabanoff, B. (2003). When and why are values important in organizations. I S. W. Gilliland, D. D. Steiner \& D. P. Skarlicki (Red.), Emerging perspectives on values in organizations (s. 3-32). Information Age Publishing.

Martinussen, W. (1984). Sosiologisk analyse: En innføring. Universitetsforlaget.

Meyer, J. W. \& Rowan, B. (1977). Institutionalized organizations: Formal structure as myth and ceremony. American Journal of Sociology, 83(2), 340-363. https://doi. org/10.1086/226550

Meyer, J. W. \& Rowan, B. (1991). Institutionalized organizations: Formal structure as myth and ceremony. I P. J. DiMaggio \& W. W. Powell (Red.), The new institutionalism in organizational analysis (s. 41-62). University of Chicago Press.

Miller, K. D. (2002). Competitive strategies of religious organizations. Strategic Management Journal, 23(5), 435-456. https://doi.org/10.1002/smj.234 
Mjelva, R. (1979). Kirken som sosio-religiøst system. Et utkast til en systemorientert analysemodell. Kirke og Kultur, 84(1), 105-116.

Myrvang, R. E. L. (2020). Kirkeverge som lokal kirkestrateg [Masteroppgave]. VID vitenskapelige høgskole.

Omland, T. \& Johannessen, K. I. (1998). Mangfold og fellesskap. En case-studie av Furuset menighet. Diakonhjemmet høgskolesenter.

Palmu, H. (1991). An open or a closed community: Leadership in the parish. Research Institute of The Lutheran Church in Finland.

Pandey, J. \& Varkkey, B. (2020). Impact of religion-based caste system on the dynamics of Indian trade unions: Evidence from two state-owned organizations in North India. Business \& Society, 59(5), 995-1034. https://doi. org/10.1177/0007650317745867

Perrow, C. (1991). A society of organizations. Theory and Society, 2o(6), 725-762.

Purchase, S., Ellis, N., Mallett, O. \& Theingi, T. (2018). Religious social identities in the hybrid self-presentations of Sikh businesspeople. British Journal of Management, 29(1), 99-117. https://doi.org/10.1111/1467-8551.12268

Rudge, P. F. (1968). Ministry and management: The study of ecclesiastical administration. Tavistock.

Rø, J. E. (1985). Kirken som arbeidsplass [Hovedfagsoppgave]. Universitetet i Oslo.

Røvik, K. A. (1998). Moderne organisasjoner: Trender i organisasjonstenkningen ved tusenårsskiftet. Fagbokforlaget.

Scherer, R. P. (1980). American denominational organization: A sociological view. William Carey Library.

Scott, W. R. (1987). Organizations: Rational, natural, and open systems (2. utg.). Prentice-Hall.

Scott, W. R. (1995). Institutions and organizations. Sage.

Selznick, P. (1957). Leadership in administration: A sociological interpretation. Row Peterson.

Sirris, S. (2015). Hvordan lede frivillige i kirken? En verdibasert og praksisorientert modell for kirkelig frivillighetsledelse. Scandinavian Journal for Leadership \& Theology, 2(1).

Sirris, S. (2016). Arbeidsdager mellom profesjon, ledelse og organisasjon. Soknepresters tidsbruk og aktivitetsmønstre. Teologisk Tidsskrift, 5(1), 60-94. https://doi.org/10.18261/issn.1893-0271-2016-01-05

Sirris, S. (2019a). Coherent identities and roles? Hybrid professional managers' prioritizing of coexisting institutional logics in differing contexts. Scandinavian Journal of Management, 35(4). https://doi.org/10.1016/j.scaman.2019.101063

Sirris, S. (2019b). «The pastors' dilemma» revisited. Religious leaders connecting the spiritual and organizational realms through conceptual work. Journal of 
Management, Spirituality \& Religion, 16(3), 290-313. https://doi.org/10.1080/14766 086.2019.1574599

Sirris, S. \& Byrkjeflot, H. (2019). Realising calling through identity work. Comparing themes of calling in faith-based and religious organisations. Nordic Journal of Religion and Society, 32(2), 132-147. https://doi.org/10.18261/issn.1890-70o8-2019O2-03

Skjevesland, O. (1998). Morgendagens menighet: Ledelse og livsform. Verbum.

Smets, M., Morris, T. \& Gümüsay, A. A. (2020). «God at work»: Engaging central and incompatible institutional logics through elastic hybridity. Academy of Management Journal, 63(1). https://doi.org/10.5465/amj.2016.0481h

Stifoss-Hanssen, H., Angell, O. H., Askeland, H., Schmidt, U., Urstad, S. \& Kinserdal, F. (2013). Ny organisering av prestetjenesten («Prostereformen»-evaluering). Diakonhjemmet Høgskole.

Struminska-Kutra, M. \& Askeland, H. (2020). Foxes and lions: How institutional leaders keep organisational integrity and introduce change. I H. Askeland, G. Espedal, B. J. Løvaas \& S. Sirris (Red.), Understanding values work: Institutional perspectives in organizations and leadership (s. 117-138). Palgrave Macmillan. https://doi.org/10.1007/978-3-030-37748-9

Tracey, P. (2012). Religion and organization: A critical review of current trends and future directions. Academy of Management Annals, 6(1), 87-134. https://doi.org/10 $.5465 / 19416520.2012 .660761$

Tracey, P., Phillips, N. \& Lounsbury, M. (2014). Taking religion seriously in the study of organizations. I P. Tracey, N. Phillips \& M. Lounsbury (Red.), Religion and organization theory (s. 3-21). Emerald Group. https://doi.org/10.1108/So733558X20140000041003

Vaccaro, A. \& Palazzo, G. (2014). Values against violence: Institutional change in societies dominated by organized crime. Academy of Management Journal, 58(4). https://doi.org/10.5465/amj.2012.0865

Van Gelder, C. (2007). The ministry of the missional church: A community led by the Spirit. Baker Books.

Vanebo, J. O. (2001). Kampen om den autoriserte organisasjonsteorien - i går, i dag og i morgen. I J. O. Vanebo \& B. Nylehn (Red.), Organisasjonsfaget. Innhold og formidling. (s 16-31). Universitetsforlaget.

Yancey, P. (1986). The church as playtypus. Leadership. A Practical Journal for Church Leadership, $\operatorname{VII}(3), 104-113$. 



\title{
Demokrati i kirke og menighet
}

\section{Frank Grimstad}

VID vitenskapelige høgskole

\begin{abstract}
This chapter discusses democracy in the context of the church means and its consequences for governance and leadership. The chapter looks at historical and current assessments of the understanding of church democracy and relates this discussion to current democracy theory. The chapter assesses justifications used for ecclesiastical democracy and considers responsibility, authority, governance and leadership. The concept of "democratic culture" and the potential for development of governing bodies and leadership to realize the (church's) political intentions are also discussed.
\end{abstract}

Keywords: democracy, ecclesiastical democracy, governance, leadership

\section{Introduksjon}

Hvordan har forståelsen av kirkelig demokrati utviklet seg og hvilken betydning har det for lederrollen å være demokratisk forankret? I prosessen mot selvstendiggjøringen av Den norske kirke, med selvstendiggjøring og frikobling fra stat og kommune, har spørsmålet om det kirkelige demokrati vært sentralt. Forut for avviklingen av statskirken i 2012 var det en forutsetning at kirken, gjennom en demokratireform, styrket kirkens demokrati og valgordning (Saglie \& Segaard, 2011, s. 156). I tillegg har dette spørsmålet vært viktig og diskutert de siste 150 år. På denne tiden har det gradvis skjedd store endringer i Den norske kirke. Ytre sett har endringene dreid seg om relasjonen til staten, men innen

Sitering av denne artikkelen: Grimstad, F. (2021). Demokrati i kirke og menighet. I S. Sirris \& H. Askeland (Red.), Kirkelig organisering og ledelse: Et verdibasert og praksisorientert perspektiv (Kap. 5, s. 107-133). Cappelen Damm Akademisk. https://doi.org/10.23865/noasp.129.ch5

Lisens: CC BY-NC-ND 4.0 
den fremvoksende kirkelige korporativiseringen har det vært tatt viktige beslutninger knyttet til styringsformer, demokratiske valg og spørsmål om hvordan man skal forstå den norske kirke som en landsdekkende og demokratisk organisasjon. Til det siste hører særlig styrings- og ledelsesspørsmålet, med konsekvenser for kirkelige lederroller. I en kirkelig kontekst kan det hevdes at demokratiet som styringsform er både ungt og skjørt (Grimstad, 2005, s. 9). Demokratiet er ingen selvsagt styringsform, men basert på historisk utvikling og institusjonelle beslutninger. Vi ser i 2021 at den demokratiske tradisjon vi har forholdt oss til er i spill i flere land i Vest-Europa. Demokratiforskningen peker på at demokratiutviklingen går i bølger som ofte møtes av motbølger (f.eks. Knutsen, 2021, s. 75ff). Statsviteren Carl Henrik Knutsen henviser til Huntington (1991) som pekte på tre slike demokratiseringsbølger: 1828-1926, 1943-1962 og 1974 og frem til i dag. Demokratiseringsbølger vil møtes av motbølger. Hvorvidt dette kan spores når det gjelder det kirkelige demokrati vil vi komme tilbake til.

En drøfting av det kirkelige demokrati som styringsform vil også måtte fokusere på styrker, svakheter og særtrekk. Det er etter hvert utviklet mål på «hvor demokratisk» et land er (Knutsen, 2021, s. 41). Et land som Norge kommer for eksempel høyt opp på slike demokratimålinger. Tilsvarende er ikke utviklet for å måle «hvor demokratisk» et kirkesamfunn er. Intuitivt vil vi tenke at den norske kirke er «mer» demokratisk enn eksempelvis mer episkopale kirkesamfunn. Vi vil derfor ha fokus på elementer som kan bidra til en forståelse av hvor demokratisk den norske kirke er og når den er demokratisk «nok» til å oppfylle kirkelige og offentlige standarder.

Frem til nå har Den norske kirke vært relativt sterkt regulert av lovgivning fra Stortinget. Fra 2021 regulerer staten kirken gjennom en kort rammelovgivning. Innenfor disse rammene har kirken frihet til å videreutvikle sin egen styringsform i det kommende tiår. Dette gir anledning til kritisk å vurdere det som omtales som det kirkelige demokrati ut fra generell demokratiteori og peke på noen av de spenninger og implisitte motsetninger som ligger latent i denne utviklingsprosessen. Som del av den forvaltningsmessige selvstendiggjøringen må kirken også bygge opp en egen administrativ handlingsorganisasjon for å forberede og iverksette 
kirkedemokratiets planer og vedtak. Denne utviklingen reiser på den ene side spørsmål om forståelsen av de valgte organers mandat og folkevalgte lederroller. På den andre side reiser det også spørsmål om hvordan ansatte ledere ivaretar en demokratisk forankret lederrolle (Hougsnæs, 2011, s. 39f). Forskningsspørsmålet som reises er: Hvordan skal det kirkelige demokrati som styringsform forstås og hvilke føringer legger det for kirkelige lederroller?

Artikkelen vil gjennomgå argumentasjonen i sentrale reformdokumenter og speile kirkelige utredninger mot demokratiteori for å peke på mulige måter å styrke det demokratiske element slik at Den norske kirke kan fremstå som en «landsdekkende og demokratisk forankret» folkekirke (Trossamfunnsloven, 2020, $\$ 10$ ).

Det har tidligere vært hevdet at spørsmålet om kirkelig demokrati langt på vei er et oversett forskningsområde (Askeland, 2001; Grimstad \& Askeland, 1999). Selv om det ikke har vært omfattende forskningsinnsats, har demokratireformen vært grundig reflektert (Rafoss et al., 2020; Saglie \& Segaard, 2011; Schmidt, 2011). Refleksjonen og forskningen på det kirkelige embetet er veldokumentert, men forskningen på det kirkelige demokrati er ikke tilsvarende sterk. Studiene som har evaluert demokratireformen har primært forsket på valgordninger i kjølvannet av demokratireformen. Det kirkelige demokratiets begrunnelse og mandat har i mindre grad vært gjenstand for oppmerksomhet.

Den norske kirke fremstår i dag som en relativt demokratisk styrt kirke (Hougsnæs, 2005, s. 4; Schmidt, 2011, s. 39f). At det kan omtales som relativt, innebærer at spørsmålet om demokrati ikke kun er et utvendig spørsmål, for eksempel relatert til valgoppslutning, men er vevet sammen med teologiske vurderinger i forhold til ekklesiologi. Kirkehistorikeren Tarald Rasmussen peker på at demokratiet er en av protestantismens grunnleggende dimensjoner: «Protestantismens grunnleggende prosjekt var å nå hele folket og gjøre hver enkelt borger til religiøs aktør» (Rasmussen, 2017, s. 132f). Enhver må stå inne for å ta ansvar for sin tro. Skolegang for flest mulig har vært og er en sentral protestantisk verdi, både for å sikre direkte tilgang til bibelteksten og for å myndiggjøre mennesker til bruk av fornuften som Guds gave. 


\section{Forankringen av det kirkelige demokratiet}

Det kirkelige demokratiet har sin formelle forankring i Stortingets lovgivningsmyndighet overfor kirken, og har vært utviklet over tid. For det første kan det hevdes at statens kirkestyre ble demokratisert ved at regjeringen ivaretok kongens grunnlovfestede oppgaver, og for det andre har Stortinget gjennom lovgivning etablert menighetsmøte (1873), menighetsråd (1920), bispedømmeråd (1933), kirkeråd (1969), kirkemøte (1984) og lovfesting av kirkelig fellesråd (1996). Senest i forbindelse med siste endringene av relasjonene mellom stat og kirke i 2017, var økt demokratisering en forutsetning fra statens side for å gi kirken frihet:

Departementet motiverer behovet for styrking av det kirkelige demokrati med målsettingen om å bevare Den norske kirke som en åpen og inkluderende folkekirke. Skal kirken kunne være dette, er den avhengig av tillit i den brede medlemsmassen. En demokratisk styringsstruktur vil etter departementets oppfatning bidra til å skape trygghet, tillit og tilhørighet hos medlemmene. (Kultur- og kirkedepartementet [KKD], 2008, s. 22)

På tilsvarende måte har den nye trossamfunnsloven, fra januar 2021, som formål å understøtte tros- og livssynssamfunn (Kap. 1, \$1). Samtidig som loven har et generelt sikte overfor alle tros- og livssynssamfunn, har den et eget kapittel som er viet den norske kirke. Dette kapitlet har en egen formålsparagraf $(\$ 10)$, der demokratiet forankres: «Formålet med bestemmelsen i dette kapitlet er å legge til rette for at Den norske kirke forblir en landsdekkende og demokratisk evangelisk luthersk folkekirke.»

Når staten har hatt et så vidt aktivt grep med hensyn til demokratisering, er det viktig å understreke at man gjorde dette i forståelse med Den norske kirke (Johnsen, 2017, s. 77). Måten å tenke på fra statens side uttrykker sentrale innsikter ved institusjonell teori: Legitimiteten i en organisasjon øker i den grad den gjenspeiler viktige verdier i omgivelsene. Kirken har ved flere anledninger drøftet demokrati og styringsspørsmålet - ikke minst med utgangspunkt i det såkalte «allmenne prestedømme». Særlig gjelder dette i forbindelse med behandlingen av utredningen «Embete og råd» på Kirkemøtet i 1988 (Kirkerådet, 1987). Spørsmålet om det kirkelige demokrati og kirkelige råds legitimitet og status er stadig til diskusjon. 
Ikke minst vil denne spørsmålsstillingen reises under utforming av fremtidig kirkeordning som må svare på en situasjon der regjering og storting ikke lenger bidrar til konkret forankring og legitimering av de demokratiske organers myndighet og rolle i kirkeordningen.

I denne debatten vil det være nødvendig å kunne reise og besvare spørsmålet om hva som er forskjellene og likhetene mellom borgerlig og kirkelig demokrati. Ettersom styrket demokrati har vært knyttet opp mot spørsmålet om og som premiss for økt kirkelig selvstendighet, har oppmerksomheten på det kirkelige demokrati i stor grad vært knyttet til valgdeltakelse og valgordninger. Debatten om hva som er viktige prinsipper og verdier i demokratiet er stor og omfattende, men har vært mindre fremtredende. Jeg vil derfor videre i dette kapitlet redegjøre for deler av denne debatten. Kapitlet tar utgangspunkt i demokratiteori, og trekker særlig veksler på bidrag som har fokusert lokaldemokrati i kommune- og kirkedemokratiet (Askeland, 2001; Bjørnå, 2005; Saglie \& Segaard, 2011; Schmidt, 2011). Professor i statsvitenskap Hilde Bjørnå representerer et analytisk grep på lokaldemokratiutvikling i Norge og Norden og vurderer dens grunnlag og hva som har vært viljen bak de ulike etapper i utviklingen i artikkelen «Demokrativerdien i det lokale selvstyret». Teologen Ulla Schmidt og samfunnsviterne Harald Askeland og Jo Saglie tematiserer kirkelig demokrati, organisering og ledelse i en norsk kontekst, relatert til et demokratiteoretisk utgangspunkt. Dette utgangspunktet gir det analytiske grep for å vurdere hvordan demokratiforståelsen fremtrer i den kirkelige reformbevegelsens dokumenter.

Den følgende drøftingen berører i mindre grad staten som demokratisk institusjon, men vil gi perspektiver på de diskusjonene som er pågående i Den norske kirke om lokalkirkens styringsform, handlingsform og selvstendighet. Kapitlet bidrar til en fornyet og oppdatert forståelse av kirkelig demokrati, styring og ledelse i en situasjon der staten, etter å ha konstituert kirkelig demokrati i lovgivning, har overlatt styringen av kirken til valgte kirkelige organer på lokalt, regionalt og sentralt nivå. I en slik situasjon er en slik analyse viktig for videreutviklingen av demokratiforståelsen i kirken.

Demokrati har sin opprinnelse i antikkens Hellas og innebar det vi i dag kaller direktedemokrati, som skiller seg markant fra det moderne 
representative demokrati. I det direkte demokratiet deltok borgerne direkte i beslutningene i byforsamlingen, mens vi i dag velger representanter som opptrer på vegne av fellesskapet. Demokrati er en måte å organisere samfunnet på og løse maktspørsmål. Det greske demokrati hadde sine begrensninger. Det var kun frie menn over 20 år som hadde stemmerett. Slaver, kvinner og eiendomsløse hadde ingen politiske rettigheter. Av Athens 300 ooo innbyggere utgjorde disse frie menn kun 40 ooo; knappe 10-15\%. Nå er det allerede pekt på at demokrati knyttes til folkestyre, det vil si en styreform hvor flertallets vilje øver den avgjørende innflytelse på styringen av stat (eller et annet nærmere definert fellesskap). Som et generelt utgangspunkt er dette oftest tilstrekkelig. En nærmere definisjon av demokrati er gitt av den amerikanske filosofen Carl Cohen, der demokrati forstås som en styreform der medlemmene av et fellesskap deltar, eller kan delta, direkte eller indirekte i beslutninger som angår dem alle (Cohen, 1971).

Folkestyret blir i moderne teori knyttet til borgerrettigheter, mens det har vært debattert i hvilken grad det kirkelige demokrati bør være åpent og allment. Denne problemstillingen representerte et konfliktpunkt i tiden frem mot innføringen av menighetsrådsloven i 1920, og loven forutsatte en konsensus om at det var dåp og det alminnelige manntall som var utgangspunkt for kirkelig stemmerett. Denne debatten berører to av tre sentrale dimensjoner i demokratiforutsetningene: bredde, dybde og rekkevidde (Saglie \& Segaard, 2011, s. 157f). Mens bredde dreier seg om hvem og hvor mange som har rett og mulighet til å delta, handler dybde om engasjement fra og informasjonsgrunnlaget for deltakerne. Formelt ble kirkedemokratiets bredde institusjonalisert som samsvarende med det statlige borgerdemokrati ved menighetsrådsloven i 1920. Dermed blir det interessant å sammenligne en allmenn forståelse av demokrati med den kirkelige demokratidiskursen. Det temaet som gjenstår, og gjøres til gjenstand for diskusjon her, er demokratiets rekkevidde, eller omfanget av saker og temaer demokratiet legitimt tar avgjørelse om.

I sin behandling av demokrati i kommunene peker Bjørnå på dilemmaet $\mathrm{i}$ at kommunene trenger handlingsrom for å kunne gjøre tingene på sin måte ut fra lokale behov, mens staten skal sikre like rettigheter og like tjenester (Bjørnå, 2005, s. 37-38). Staten er opptatt av å finne løsninger 
som ivaretar både statens og lokalsamfunnets behov. Ikke ulikt spørsmålet om å balansere lokal kirkelig selvstendighet og Kirkemøtets ansvar for å holde kirken sammen (Holbæk, 2019). Verdien demokrati har tradisjonelt vært knyttet til borgernes innflytelse på og medbestemmelse: «Denne demokrativerdien har sitt teoretiske fundament i et republikansk ideal om meningsdannelse og deltakelse, og et kommunitaristisk ideal om vedlikehold av et lokalt fellesskap og en lokal identitet» (Bjørnå, 2005, s. 38). Realiseringen av dette lekmannsstyret krever et stort handlingsrom som skal fylles med deltakelse «nedenfra». Bjørnå påpeker at det $\mathrm{i}$ verdiforståelsen også finnes en annen tradisjon: «Det liberale demokrati har fokus på individuelle elementer, på ansvarliggjøring og på brukernes behovstilfredsstillelse. Det nyliberalistiske demokratiidealet setter fokus på at staten skal sikre et minimum av grunnleggende rettigheter og legge til rette for valgfrihet, pluralisme og konkurranse» (Bjørnå, 2005, s. 39).

Sentralt i Bjørnås drøfting står skillet mellom begrepene borger og bruker. Den første forståelsen kan knyttes til deltakelse og meningsdannelse som selve kjernen i demokratiet. Den andre handler om å styre minst mulig overfor individet, men staten skal legge rammer for valgfrihet lokalt. Ut fra et borgerperspektiv er borgernes meningsdannelse og det kollektive element viktig. "Borgerne er engasjert i å opprettholde et lokalt fellesskap gjennom folkelig engasjement og fornuft. Den kulturelle arv skal ivaretas og vitaliseres og for kommunen blir det viktig at den lokale identitet blir ivaretatt og videreutviklet» (Bjørnå, 2005, s. 41).

\section{Hvordan forstår kirken det kirkelige demokrati?}

Gjennomgangen av de prinsipielle sider av demokratiforståelsen viser tre perspektiver/kategorier fra den allmenne debatten det er viktig å analysere det kirkelige demokrati ut i fra. For det første ser jeg det som viktig å drøfte hvorvidt det kirkelige demokrati har helt allmenne trekk, eller om det også har eller bør utvikles som en særegen variant av demokrati. Her vil analysen av begrunnelsen av og for kirkelige demokrati, slik det fremtrer i reformbevegelsens dokumenter, kunne speiles mot generell demokratiteori. Deretter ser jeg det som viktig å etterspore argumentene for hvordan det kirkelige demokrati skal organiseres. Til dette aspektet 
hører dels forholdet mellom lokalt og sentralt nivå, men også hvordan den kirkelige handlingsorganisasjon styres og ledes i forhold til å være demokratisk forankret.

Jeg vil i de følgende analysere kirkedemokratiet ut fra de kategorier som fremheves av Bjørnå og Askeland. Likevel anlegges en historisk synsvinkel for å peke på en del av de særtrekk som har utviklet seg i kirkelig demokrati. Dernest en vurdering av de elementene som er viktige for kirken, eller som kirken har overtatt fra omgivelsene.

Historisk sett har mange kirker vært preget av en hierarkisk struktur der skillet mellom lekfolk og prester har vært viktig (Hegstad, 2019, s. 170). Skillet har vært begrunnet teologisk ut fra et skille mellom ordinerte og uordinerte. For den lutherske reformasjonen var det viktig å ta et oppgjør med et slikt skille. Luthers begrunnelse er først og fremst å finne i dåpsteologien. Det er dåpen som gjør mennesket til et fullverdig medlem av kirken med alle rettigheter og plikter (Hegstad, 2019, s. 170). Det egentlige ordinasjonssakramentet er dåpen - der har man i prinsippet fått alt som er nødvendig for ansvar og oppgaver i kirken. Ut fra et ordenssynspunkt kan det differensieres på oppgaver, men alle som utfører oppgaver - også ordinerte - gjør det på vegne av fellesskapet. Reformasjonen la grunnlaget for lekfolkets rolle, men en bredere mobilisering av lekfolket fikk man først på 1800 tallet, ikke minst gjennom vekkelsesbevegelsene. Allerede midt på 180o-tallet ble dette syn fremmet i Stortinget ut fra et privat lovforslag om å lovfeste valgte kirkelige organer:

I hver menighed antages at burde være et slags kirkeligt formandskab eller kirkeraad, bestaaende av et vist antal at menighedens ældre og christeligsindede mænd, der skulle bistaae præsten med at paase, at sædelighed og orrden i almindelighed, og et christeligt liv i særdeleshed føres i menighederne baade af over- og underordnede. Disse mænd maate til vise tider samles med præsten og afgive deres beretning om forholdene. (Indst og Besl O No 56, 1869, s. 16)

På 180o-tallet skjer det parallelt en utstrakt etablering av frivillige organisasjoner både i og utenfor statskirken (Hegstad, 2019, s. 171). Dette førte til en utvikling i retning av demokratisering innenfor statskirken. I 1859 ble det igangsatt en offentlig kommisjon for å se på muligheten for å utvikle 
et visst kirkelig selvstyre innenfor statskirkeordningen (Rasmussen, 2005, s. 262).

Kirkekommisjonen av 1859 foreslo å opprette både menighetsråd og Kirkemøte. De skulle være organer med et kristelig formål og velges på bakgrunn av innskrenket stemmerett. Regjeringens behandling opplevde reformtilhengerne som stor nedtur. Forslaget utløste en kompetansestrid mellom kongen og Stortinget. Kongen ville ha Kirkemøte, men Stortinget ville ikke bevilge penger til dette. Stortingsflertallet regnet med at embetsmennene ville dominere Kirkemøtet, og ville ikke gi embetsmennene enda mer makt. Stortinget ville ha menighetsråd, men kongen nektet sanksjon. Det kunne bli en plattform for mer bondemakt. Slike menighetsråd ville ikke embetsmennene ha (Andresen, 2015, s. 1).

Det skulle gå femti år før lovfesting av menighetsråd ble en realitet $\mathrm{i}$ 1920, der også fellesrådet ble en lovfestet mulighet. Denne langsomheten medførte at reformbevegelsen bidro til etablering av menighetsmøter og frivillige kirkelige landsmøter fra 1873. Det var stor uenighet i årene frem mot lovfesting av menighetsråd om hva slags kirkelig demokrati kirken skulle ha - ikke minst hvem som skulle ha stemmerett: alle døpte, eller begrenset til kun nattverdmenigheten? Det endte i 1920 med at dåpen var kriteriet for stemmerett. På begynnelsen av 1900-tallet forsvant også som en konsekvens av liberale tenkemåter dåpsplikten (1904), konfirmasjonsplikten (1911) og nattverdplikten (1913). Fra 1933 ble det også lovfestet bispedømmeråd og bispemøte.

Fra 1960-tallet økte den kirkelige aktivitet betydelig i norske menigheter. Med utgangspunkt i det samme lovverk tok lekfolk større ansvar. Redaktør for Kirkens informasjonstjeneste, Gunnar Rødahl (1988) peker på at mange viktige initiativ for å vitalisere og strukturere den norske kirke bidro til at man fikk «samordningsorganer» (f.eks. bispedømmerådenes fellesråd) som forløpere til lovfesting av organer. I dette arbeidet spilte bispemøtet også en sentral rolle i fravær av andre strukturer (Rødahl, 1988, s. 7). Kirkerådet, som bispedømmerådenes fellesråd, kom på plass i 1969, og betydde en viktig impuls i å tenke demokrati og styringsansvar i kirken. Kirken hadde fått et «topporgan» som tok fatt på oppgaver innenfor et bredt felt. Ikke uten grunn omtaler journalisten Jan Arild Holbæk dette som «Rådet som forandret kirken» (Holbæk, 2019). 
På slutten av 1980-tallet var fortsatt hovedgrepet store reformer innenfor statskirkens rammer. Det førte til tre viktige vedtak:

- opprettelsen av et lovfestet Kirkemøte i 1984

- $\quad$ opprettelsen av en lærenemnd for Den norske kirke i 1985

- selvstendiggjøring av den lokale kirke som eget rettssubjekt og to ansvarlige demokratiske organer - menighetsråd og kirkelig fellesråd

Opprettelsen av disse organene var viktige milepæler der rådenes styring og daglig leders lederrolle innebær en vesentlig demokratisering av kirken. Disse vedtak i Stortinget bygget på en viktig teologisk og ideologisk klargjøring i det nylig opprettede Kirkemøtet.

Ett av de aller første initiativ som ble tatt av det nyetablerte Kirkemøtet i 1984 var å igangsette en utredning om kirkelig styring, ledelse, beslutningsmyndighet og beslutningsmakt (Sak KM 1984 05/84). Drøftingen skjedde på bakgrunn av et "problemnotat» ${ }^{1}$ som konkluderte med at Den norske kirke ikke skal styres ut fra en geistlig eller hierarkisk modell - verken under konge eller erkebiskop - men skal styres etter demokratiske prinsipper basert på kirkelige valg. På bakgrunn av diskusjonen i Kirkemøtet ble det nedsatt en bredt sammensatt arbeidsgruppe. Utredningen «Embete og råd» ble lagt frem i 1987, og behandlet av Kirkemøtet i 1988. Behandlingen i utredningen «Embete og råd» og Kirkemøtet i 1988 bekreftet og tydeliggjorde Kirkemøtets vedtak fra 1984 (Sak KM 05/84).

Prinsippet om at styringsansvaret $i$ kirken springer ut av menigheten og er helhetlig forankret i menighetens valgte styringsorganer blir fastholdt uten forbehold. Det er ikke noe som er kirkelige rådsorganer - dvs. representanter for kirkens alminnelige medlemmer - uvedkommende. Tradisjonen som opererer med at presten og menighetsrådet har selvstendige og uavhengige kompetanser eller myndighetsområder blir avvist

1 «Problemnotat om embete og råd», Kirkerådet mai 1984, ført i pennen av Knut Andresen på vegne av en arbeidsgruppe bestående av biskop Andreas Aarflot, sokneprest Aage Lunde og vit. ass. Chr. Wegger-Strømmen. Notatet ble sendt på høring og dannet grunnlaget for den senere utredning om «Embete og råd» som ble behandlet av Kirkemøtet i 1988. 
som teologisk uholdbar og dermed også problematisert som rettslig holdbar (Kirkerådet, 1987, s. 132). Ved siden av denne grunnmodellen viderefører utredningen uten særlig diskusjon den klassisk lutherske posisjonen om at embetet er innstiftet av Gud. Den konkret utformede styringsmodell plasserte derfor blant de valgte rådsmedlemmene alltid en prest. Ikke ut fra at embetet har selvstendig styringsrett, men ut fra tanken om at embetet hører hjemme i styringsorganet. Tre ulike begrunnelser finnes i teksten:

- Selv om kirken i Bibelen kalles Guds folk, er den ikke folkestyrt, men styrt av Kristus gjennom Ordet og sakramentene (Kirkerådet, 1987, s. 70).

- Historisk har personer i forkynner ansvar alltid inngått i menighetens ledergruppe (Kirkerådet, 1987, s. 80).

- Det henvises til læreutvalgets (NOU 1985: 21) argument om forsvarlighetsprinsippet. Det burde være en teologisk sakkyndig i ethvert kirkelig styringsorgan.

Kirkemøtet i 1988 behandlet saken, etter en høringsrunde, og la i vedtaket vekt på å understreke

at fremveksten av rådene er et uttrykk for at mennesker som gjennom dåpen har blitt kirkemedlemmer, tar ansvar for sin kirke. Utredningen innebærer en sterk understrekning og oppvurdering av det ansvar lekfolket har og skal ha i kirkestyret og i kirkens virksomhet. (Sak KM 11/88)

Den historiske gjennomgangen viser en betoning av menighetens fellesskap. Det er menighetens medlemmer, som svarer til borgerne i det allmenne demokrati, som er fellesskapet det felles ansvar er forankret i. Det understrekes tydelig at ut fra en teologisk forståelse er det det lokale fellesskap som er stedet der kirke skjer. Øvrige overbygninger er der for å understøtte det lokale fellesskap.

En ny diskusjon om kirkelig demokrati var knyttet til å skille stat og kirke fra 2008. Reformene bygget på det prinsipielle grunnlag som ble lagt i 1980-årene, men det ble lagt tydelige føringer på styrking av demokratiet som forutsetning for selvstendiggjøringen av Den norske kirke på 
nasjonalt plan. Et premiss for videre endring av forholdet mellom staten og Den norske kirke var at det skulle gjennomføres en demokratireform: «Det bakenforliggende resonnement er at dersom myndigheten skal overføre makt til kirkelige organer, så er det nødvendig at de kirkelige organene har sterkere demokratisk grunnlag» (Schmidt, 2011, s. 8).

Stortingets krav om styrket demokrati for overføring av myndighet fra stat til kirke førte til at det i samråd med kirken ble opprettet en hurtigarbeidende arbeidsgruppe (Johnsen, 2017, s. 77). Arbeidsgruppen betød også at det ble tydeliggjort en del av de prinsipielle vurderinger som hadde røtter tilbake til vedtaket om «Embete og råd» (Sak KM 5/88). De pekte på at «læren om det alminnelige prestedømme som ble formulert av Martin Luther, er et fundamentalt kirkelig premiss for at demokratiske ordninger har legitimitet» (KKD, 2008, s. 28).

Arbeidsgruppen er videre opptatt av å understreke at alle døpte har de samme muligheter i Guds vilje og Guds ord. Tanken om det allmenne prestedømme begrunner den enkelte kristnes verdighet, men innebærer også et ansvar for at menighetens liv tilhører hele fellesskapet (KKD, 2008, s. 28). Samtidig ble det understreket at de kirkelige valg må ha demokratisk legitimitet (KKD, 2008, s. 30). Det kirkelige valgsystem må tilfredsstille allmenne krav til demokratisk legitimitet slik vi kjenner det fra samfunnet for øvrig. Arbeidsgruppen peker særlig på mulighet for å delta for alle stemmeberettigede, reelle påvirkningsmuligheter på hvem som blir valgt, informasjon om hva valget gjelder og tilgjengelighet (KKD, 2008, s. 31).

Arbeidet med å styrke demokratiet i Den norske kirke har derfor flere dimensjoner. Det handler om å styrke medlemmenes mulighet til engasjement og deltagelse, om å styrke det faktiske engasjement og den faktiske deltagelsen, men også om hvilken innflytelse valgte organer har og om utvikling av en demokratisk kultur i kirken (KKD, 2008, s. 87). Viktige tema for å realisere dette var: etablering av reelle valgmuligheter; mer direkte valg; kirkevalg samtidig med offentlige valg. En studie av kirkevalget i 2019 (Rafoss et al., 2020) viser til at reformene har ført til $ø$ kt valgdeltakelse og til at nyere og bredere velgergrupper deltar. Det er imidlertid fortsatt uklarheter når det gjelder reelle valgmuligheter som viser hva kandidater står for. Etableringen av Åpen Folkekirke med egne 
lister har bidratt til å tydeliggjøre og øke engasjementet (Rafoss et al., 2020, s. 21-22).

Etter denne forfatterens oppfatning fremstår lovfesting av de kirkelige rådene gjennom kirkeloven av 1996 som en juridisk oppfølging av Embete og råd-utredningen (Kirkerådet, 1987) og vedtaket i Kirkemøtet 1988 (KM 11/88). Tilsvarende er fokuset på styrking av demokratiet som forutsetning for etablering av et sterkt kirkelig topporgan en oppfølging av det samme. Begge reformer er teologisk forankret i kirkens prinsipielle vedtak i 1980-årene. Samtidig vil jeg peke på at debatten om myndighets- og ansvarsfordelingen mellom den vigslede tjeneste og lekfolkets rolle ikke er et avsluttet kapittel.

\section{Utviklingen av demokratiets handlingsorganisasjon}

Når et demokratisk valgt organ er tillagt oppgaver som skal løses i samfunnet, av et visst omfang og med tilsatte medarbeidere, trenger det valgte råd en handlingsorganisasjon for å lede og utøve virksomheten. Det overordnede ansvar for ledelsesfunksjoner er normalt lagt til daglig leder for den enkelte virksomhet. Det allmenne lovverk som regulerer virksomheter og arbeidsforhold, har oftest lagt til grunn at enhver virksomhet kan eller skal ha en daglig leder. Dette er konsekvent innarbeidet i kirken - særlig etter lovendringene i 1996 (kirkeloven) og vedtatt av Kirkemøtet i 2019 som gjeldende også for menighetsråd (kan), fellesrådet, bispedømmeråd og Kirkeråd.

Hvilken rolle denne lederfunksjonen skal ha med tanke på å bygge demokrati, er mindre utredet (Grimstad, 1999). Det er imidlertid tydelig uttrykt at «et velfungerende demokrati er avhengig av en godt fungerende administrasjon som forestår utredning og oppfølging av de saker som behandles i de valgte organene», samtidig som de valgte organene må ha den nødvendige demokratiske kontroll med administrasjonens arbeid (KKD, 2008, s. 31).

Svært mye av ledelsesdiskusjonen i kirken har handlet om hvem som er best skikket til å lede kirkelig tilsatte. Den svenske statsviteren Lennart Lundquist er i boken Demokratins väktare (1998) opptatt av hvem som har ansvaret for demokratiets «livskraft og overlevelsesevne» (Lundquist, 
1998, s. 11), og peker særlig på den tjenesten/stillingen som handler om å tilrettelegge og følge opp demokratiske organer og vedtak (s. 15). Sentralt i dette står lederansvaret med å være målbærere av et «offentlig ethos» (Lundquist, 1998, s. 54). Dette offentlige ethos handler om lojalitet, åpenhet og det å handle til fellesskapets beste. Lundquist (1998, s. 100) forutsetter ut fra normativ teori at demokratiets vokter og tjener er preget av:

- disiplin

- pålitelighet

- rettferdighet

- profesjonell lydighet (ikke obstruere politiske vedtak) og lojalitet mot fattede vedtak

- integritet

Tilsvarende adresserer arbeidsgruppen bak innstillingen Styrket demokrati i Den norske kirke at «For den norske kirke som folkekirke er det viktig at kirkeforvaltningen hviler på prinsipper og fellesverdier som likhet, rettferdighet, åpenhet, offentlighet og krav til saksbehandlingen. (KKD, 2008, s. 31). I veiledningsmateriell, særlig fra KA og Kirkerådet, er det etter 1997 søkt å tilrettelegge denne lederrollen blant annet med formålsformuleringer som «Kirkevergen er daglig leder av kirkelig fellesråds virksomhet og skal lede virksomheten på en slik måte at rådet kan utføre de oppgaver som følger av lovverk og kirkelige organers vedtak og bestemmelser» og videre at «Kirkevergen skal sikre at kirkelig fellesråd gis beste mulig grunnlag for å [...] utforme mål og planer, fordele ressurser, kontrollere at målene nås» (KA, 1997, s. 10). Overfor fellesrådets «handlingsorganisasjon», dvs. de tilsatte i fellesrådet, skal kirkevergen utvikle god personalpolitikk og være overordnet for andre stillinger i sekretariatet.

Hvilken rolle denne demokratiets vokter og tjener skal ha, har gjennomgått en viktig utvikling i offentlig og kirkelig historie. Den danske organisasjonsforskeren Betina Wolfgang Rennison (2004, s. 98) har forsket på ledelsesbegrepets historie i offentlig sektor. Hun peker på at det de siste femti år har skjedd en utvikling i forventninger til offentlig ledelse fra lojal administrator og kontrollør til strateg med fokus på politikk og 
utvikling. Endring i titler har vært en materialisering av dette. Rådmannen har gått fra kontorsjef til administrasjonssjef til kommunedirektør fra 2021 som følge av endringene i kommuneloven. Slik har det også vært på kirkelig sektor - et eksempel her er daglig ledelse på bispedømmenivå. Fra bispedømmesekretær frem til 9o-tallet via administrasjonssjef i 9o-årene til stiftsdirektør fra årtusenskiftet. Lokale lederstillinger har ikke gjennomgått tilsvarende endringer i titler. Menighetssekretær ble ofte konvertert til administrasjonsleder i fra midten av 9o-tallet, men vi har til gode å se «menighetsdirektører».

Gjennom dette har jeg søkt å vise at kirkelige og til dels offentlige utredninger har vært fokusert på prestens rolle i det demokratiske organ: vokter av teologien og lojal mot evangelisk lære. Voktere og tjenere av demokratiet er ikke tilsvarende adressert, og er et svakt punkt i utvikling av et kirkelige demokrati basert på og tuftet på offentlig ethos.

\section{Hvilke særtrekk har det kirkelige demokrati?}

Med utgangspunkt i Schmidt (2011) og Askeland (2001) vil jeg plassere det kirkelige demokrati med særtrekk som et politisk demokrati og ikke som et organisasjonsdemokrati. Et organisasjonsdemokrati er forstått som et beslutningssystem for et fellesskap som du frivillig melder deg inn i og ut. Hvorvidt det kirkelige demokrati kan forstås som organisasjonsdemokrati og politisk demokrati har vært drøftet i ulike evalueringsrapporter fra KIFO, Institutt for kirke-, religions- og livssynsforskning (Holberg et al., 2015; Rafoss et al., 2020; Schmidt, 2011; Schmidt \& Mogstad, 2010). Det konkluderes med tre viktige forskjeller mellom Den norske kirke og frivillige organisasjoner. For det første selve medlemsstrukturen, der innmelding $\mathrm{i}$ en organisasjon vanligvis er en frivillig aktiv handling, mens man i Den norske kirke blir medlem som barn gjennom dåp. For det andre at man som medlem i en organisasjon kan uttrykke misnøye ved å melde seg ut og eventuelt inn i en annen organisasjon. Å melde seg ut av Den norske kirke kan oppleves mer vidtrekkende enn å melde seg ut av en interesseorganisasjon. En tredje grunn kan være at medlemskap kan forbindes med tilgang til tjenester der man ikke opplever at det er naturlige alternativer (Rafoss et al., 2020, s. 25). 
Særtrekkene ved det kirkelige demokrati handler om at skriften, ikke mennesket, er høyeste instans (Askeland, 2001, s. 286). Det handler også om at ikke alle medlemmene i rådene er valgt ved alminnelige valg. Rådene på alle nivåer har embetsbærere som medlemmer. I regionale og sentrale organer sitter også kirkelig tilsatte. Skriften som høyeste norm er ivaretatt gjennom rådenes lojalitetsforpliktelse mot evangelisk-luthersk lære.

At geistlige tjenestemenn og kirkelig tilsatte er ordinære medlemmer med full stemmerett $\mathrm{i}$ alle saker er de siste årene utfordret, blant annet $\mathrm{i}$ forbindelse med utvikling av fremtidig kirkeordning. ${ }^{2}$ Modellen er utformet under et statskirkelig styre der arbeidsgiveransvaret lå i staten - ikke i en situasjon der tjenesten med ord og sakrament har stemmerett over hele bredden av saker - inklusive kirkeordnings- og styringsspørsmål, økonomi og arbeidsgiveransvar. ${ }^{3}$ Dette utfordrer den grunnleggende forståelsen som bispemøtet (jf. Kirkerådet, 1987) understreket om at prestetjenesten var representert som «teologisk veileder og coach» (BM o8/2016).

Balanseringen av lokalt handlingsrom og behovet for felles løsninger er krevende. I debatten om likekjønnet vigsel ble dette satt på prøve. Kirken sentralt har behov for «like tjenester» for brukerne i trossamfunnet Den norske kirke. Kirken lokalt kan ha behov for å finne egne løsninger. Dette reiser også spørsmål om rekkevidden av det kirkelige demokrati. Tar vi utgangspunkt i Kirkemøtets behandling av «Embete og råd» (1988) og den tilhørende utredning (Kirkemøtet, 1987), har jeg pekt på at de var opptatt av at "prinsipielt er intet rådene uvedkommende». Premisset for dette er at den ordinerte tjeneste er til stede i rådet og dermed er en blant dem som utgjør rådet (altså det demokratiske organ) der denne helhetlige kompetansen forvaltes og samspiller med styringsorganet som fellesskap.

I hvilken grad kan det identifiseres områder som fremdeles synes å være rådene uvedkommende? Ved lovrevisjonen i 1996 ble kirkelig

2 Omtalt i blant annet «Fremtidig organisering av arbeidsgiveransvaret» (KA 2008) og i arbeidsgruppen som forbereder ny kirkeordning (Kirkerådet 2020).

3 I forbindelse med forslag til ny kirkeordning har en arbeidsgruppe (1.10.2020) konkludert med at Kirkemøtet bør bestå av folkevalgte medlemmer pluss biskopene og at kategorien lek kirkelig tilsatt bør bortfalle. 
undervisning, diakoni og kirkemusikk tillagt rådene, som deres ansvarsområde i tillegg til den generelle orienteringen mot alt som kan gjøres for å vekke og nære det kristelige liv i menigheten. På grunn av at staten fortsatt var arbeidsgiver for prestetjenesten var gudstjenestelivet et ansvar for denne strukturen, og ikke lagt som ansvar for lokale kirkelige råd. En styrking av den lokale demokratiske styringen vil være å endre kirkeordningen $\$ 12$ (Kirkeordning for Den norske kirke, 2019) slik at menighetsrådets ansvar blir «å innarbeide gudstjenesteliv, kirkelig undervisning og kirkemusikk». Som en konsekvens av at denne virksomheten legges til menighetsrådet vil det være naturlig at det tilliggende arbeidsgiveransvar for stillingene legges til lokalt kirkelig organ. Dette vil være i tråd med forståelsen av «intet er rådene fremmed» (KM o1988).

I kirkeordningen er det samtidig vedtatt av Kirkemøtet at «de kirkelige råd etter denne ordning skal utføre sitt arbeid i lojalitet mot Den norske kirkes læregrunnlag» (Kirkeordning for den norske kirke, 2019, $\$ 37$ ). Etter skillet mellom stat og kirke er dette læregrunnlaget presisert og utvidet i forhold til tidligere lovgivning, som henviste til «den evangelisklutherske lære». Den norske kirkes læregrunnlag er kirkeordningen (2019, $\$ 1)$, definert som

Den norske kirke er en evangelisk-luthersk kirke som bekjenner troen på den treenige Gud og evangeliet om frelse i Jesus Kristus slik det er gitt oss i Det gamle og Det nye testamente og uttrykt i den apostoliske, den nikenske og den athanasianske trosbekjennelse samt den uforandrede augsburgske bekjennelse fra 1530 Luthers lille katekisme.

Det er også lagt til grunn at «Den norske kirkes ordninger og praksis skal være i samsvar med Den norske kirkes grunnlag». Endringer i kirkens grunnlag krever to tredjedels flertall, og kan kun skje etter en forutgående behandling av Bispemøtet (Kirkeordning for Den norske kirke, \$2). Denne presisering av forpliktelsen og presisering av Bispemøtets rolle kan etter min oppfatning sees på som en tydeliggjøring av særtrekkene ved det kirkelige demokrati. Den kan også leses som et utvidet behov for teologisk kontroll og veiledning fra den vigslede side i rådet. Få nyvalgte medlemmer av kirkelige organer vil være vel bevandret i den athanasianske trosbekjennelse. Det er verdt å merke seg at dette innebærer en 
forpliktelse på lojalitet i forhold til hvilke demokratiske ordninger som kan gjelde for Den norske kirke. Disse nye og utvidede bestemmelser kan gi grunnlag for økt bevissthet på den vigslede tjenestes plass i rådet. Kjennskap til læren forutsetter at medlemmene er opptatt av kirkelige spørsmål. «Prestens rolle i saker der viktige overveielser skjer, er å bidra til å stille spørsmål, gi hjelp til å reflektere og vurdere aktuelle spørsmål og utfordringer ut fra sin fagteologiske kompetanse» (Grimstad, 2001, s. 11). Det kan imidlertid også tolkes som en skjerping av særtrekk og forpliktelse på rådenes arbeid som trenger voktere og kontrollører. Tilsvarende vil det kirkelige tilsyn ha et tilsynsansvar med det lokale kirkelige arbeid (Tjenesteordning for biskoper, 2016, $\$ 1$ ).

Det representative demokrati er et demokrati der folket velger representanter til å styre for seg. Ulike politiske grupperinger kjemper i åpne, frie valg om å vinne legitimiteten til å styre politikken innenfor et gitt territorium i en gitt periode. Hvordan fremstår det kirkelige demokrati ut fra en slik forståelse?

Det er minst to særtrekk det er viktig å ha fokus på ut fra vårt overordnede spørsmål i denne artikkelen. Det ene er representativitet: Arbeidsgruppen bak innstillingen Styrket demokrati i Den norske kirke omtaler representativitet og legitimitet på følgende måte:

Begrepet kirkelig representativitet sikter til den ordinerte tjeneste, både bispeog prestetjenesten og av kirkens medlemmer. I vår kirke inkluderer dette en egen representasjon av leke kirkelige tilsatte (mens det er til vurdering om andre vigslede skal innlemmes i den ordinerte tjeneste). (KKD, 2008, s. 25)

Denne forståelsen av kirkelig representativitet bryter med en allmenn forståelse av representativt demokrati. Den avklarer heller ikke forholdet mellom lekfolk som uttrykk for det allmenne prestedømme og hva f.eks. leke kirkelige stillinger bidrar med av legitimitet. Lokalt er demokratiet organisert med ett særtrekk: den særskilte tjeneste med ord og sakrament sin plass i rådet for å bidra til at arbeidet skjer i lojalitet med evangelisk luthersk lære. Leke kirkelige tilsattes innflytelse, på regionalt og sentralt nivå, er regulert i tråd med medbestemmelse for øvrig arbeidslivet.

Disse særtrekkene er i betydelig grad med å utydeliggjøre de demokratiske trekk i kirken. Lokalt er utfordringene å forholde seg til 
prestetjenestens rolle i å vokte teologien. Presten er både vanlig medlem, men også fortolker av rådets handlingsrom i teologiske spørsmål. En forskjell mellom lokalt og regionalt nivå er i tillegg at lokale kirkelige organer er beslutningsdyktige selv om presten ikke er der som «vokter» av teologien, mens bispedømmerådet ikke er beslutningsdyktige uten at biskopen er til stede som «vokter» av om beslutningene som tas er i tråd med evangelisk luthersk lære.

Uklarheten om hvilken legitimitet leke kirkelige ansatte tilfører det kirkelige demokrati og arbeidet med å utvide med andre vigslede som ex officio medlemmer av de kirkelige råd (KKD, 2008, s. 25) bidrar samlet sett til å delegitimere lekfolks ansvar og myndighet. Et potensiale i videre utvikling av det kirkelige demokrati slik det programmatisk omtales med utgangspunkt i det allmenne prestedømme, vil være å lagge rammer for når og i hvilke saker prestetjenestens rolle som «vokter» kan avgrenses fra saker som omhandler ens egen rolle, posisjon og myndighetsutøvelse.

Det andre vil være å gjennomtenke at ordinertes/vigsledes rolle i kirkestyret er styrket ved skillet mellom stat og kirke. Ved å være fullverdige medlemmer av sitt eget arbeidsgiverorgan har de svekket den demokratiske mulighet for styring og ledelse.

\section{Hva innebærer demokratisk forankret styring og ledelse?}

Bjørnå har pekt på viktige premisser for et levende demokrati - i første rekke ansvar og oppgaver som mobiliserer (Bjørnå, 2005, s. 40). Det kirkelige lovverk som Stortinget vedtok i 1996 la for første gang oppgaver som trosopplæring, diakoni og kirkemusikk til de lokale demokratiske organer. Gudstjenestelivet var fortsatt et ansvar for prestetjenesten som ikke ble berørt av reformen. Stortingsmeldingen Makt og demokrati (St.meld. nr. 17 (2004-2005)) $)^{4}$ påpekte hva som får lokaldemokratiet til å forvitre:

4 Meldingen pekte i tillegg til disse punkter på «partier» som en vesentlig bidragsyter til politikkutvikling. 
- $\AA$ ha makt uten ansvar

- $\AA$ forvalte ressursmangel

- Sentral detaljstyring

Alt dette er etter min oppfatning særdeles relevant for å forstå det kirkelige lokaldemokrati (Grimstad, 2005, s. 15). For det første er det fortsatt grunn til å se på de lokalkirkelige organers reelle handlings- og styringsrom. For det andre viser evalueringsrapporten Samstyring $i$ ubalanse (Nødland et al., 2014) at utvikling av lokalkirkelig demokrati er avhengig av personalressurser som kan legge til rette for og følge opp demokratiske styringsorganers ansvar og myndighet. At samstyringen er i ubalanse skyldes i hovedsak at de kirkelige fellesrådene fikk lovfestet daglig leder, mens menighetsrådene ikke fikk det. En ytterligere overføring av oppgaver til lokalkirkens organer vil etter min oppfatning gi større ansvar og engasjement, men også kreve ledelsesressurser.

Forskningsspørsmålet i denne artikkelen er hvordan det kirkelige demokrati som styringsform skal forstås og hvordan det legger føringer for kirkelige lederroller. Med utgangspunkt i Bjørnå har jeg ført en viss sammenligning med det kommunale demokrati som modell og forståelsesramme. Når det gjelder den demokratiske lederrollen (leder av rådet) er denne ikke lovregulert, men formelt regulert gjennom virksomhetsregler vedtatt av Kirkemøtet. Modellen har vært hentet fra det kommunale selvstyre: I møtet mellom rådsleder og daglig leder møtes politikk og administrasjon tilsvarende møtet mellom ordfører og kommunedirektør (tidligere rådmann) i kommunal sektor (Grimstad, 1999, s. 51).

To hovedforskjeller i forhold til det kommunale demokrati fremstår tydelig: Det kommunale demokrati oppfyller fullt ut definisjonen om det representative demokrati ved at politikkutforming skjer gjennom partier. Det andre er at ordførervervet innebærer frikjøp, slik at det blir mulig å være folkevalgt leder på heltid eller deltid. Rollen som folkevalgt i en kirkelig kontekst er i hovedsak et fritidsverv med unntak av valgt leder av Kirkerådet.

For ledere av kirkelige demokratiske organer fremstår det som utfordrende å utvikle (kirke)politiske vurderinger uten et partiapparat å diskutere saker i. Det er også en utfordring å utføre kontroll- og 
styringsfunksjonen. Særlig vil dette gjelde større fellesråd, regionale og sentrale organer. En styrking av demokratiet i kirken vil kunne skje gjennom mer refleksjon over hva lederen trenger, både av støtte og rom, for å fylle rollen. Dette kunne f.eks. skje ved etablering av (kirke)politiske rådgivere knyttet til sentrale stillinger.

Demokratiets innerside handler om demokratisk kultur og hvordan vi legger til rette for forholdet mellom styring og ledelse. Viktige tema her er saksbehandling, debattkultur og ryddighet i forholdet mellom politikk og administrasjon i kirken. Det handler om

- den respektfulle samtalen

- åpen debatt

- tilrettelegging for gode vedtak

I evalueringen fra KIFO (Schmidt \& Mogstad, 2010) påpekes det at kirkelig demokrati står noe tilbake når det gjelder «sakslistekontroll» og «opplyst forståelse». Det første handler om at medlemmene må ha reell mulighet til å bestemme hvilke saker som skal avgjøres gjennom en demokratisk beslutningsprosess. «Opplyst forstålse» handler om at ethvert medlem må ha tilstrekkelige og like muligheter til å utforske alternativer og konsekvenser (Schmidt \& Mogstad, 2010, s. 20). Bak dette ligger en påpekning av at i en demokratisk kultur er det den valgte leder som har kontroll på sakslisten - ikke administrasjonen. Det er ikke administrasjonens eller daglig leders møte, men den folkevalgte leder og medlemmenes. Bak opplyst saksbehandling handler det blant annet om at det er mangelfulle saksorienteringer eller fravær av saksbehandling, men det peker også på at saker skal belyses på en slik måte at også de som er imot vedtaket skal finne argumenter for sitt syn i saksorienteringen. Det handler også om at demokratiets «innerside» tilsier at det er folkevalgte som skal diskutere. Tilsatt daglig leder skal ha sagt sitt i saksorienteringen, men skal i hovedsak gi utfyllende saksopplysninger i møtet.

Kirkeordningen vedtatt av Kirkemøtet i 2019, gjeldende fra 1.1.2021, viderefører kirkelovens bestemmelser der «Kirkelig tilsatte som i denne egenskap har medvirket ved tilretteleggelsen av grunnlaget for avgjørelse [...] skal alltid anses som ugild når saken behandles i lovbestemt organ». 
Kirkeordningen viderefører også at «Biskopen regnes ikke som tilsatt i forhold til denne bestemmelse. Det samme gjelder prost og annen prest som enten i kraft av sin stilling eller etter oppnevning av biskopen er medlem av et organ for soknet» (Kirkeordning for Den norske kirke, 2019, $\$ 42$, 3. ledd). Dette er med på å svekke grunnleggende demokratiske verdier. Poenget med daglig ledelse er å bidra til å bygge demokratisk kultur gjennom ryddig tilrettelegging og oppfølging. Det skal handle om å dyktiggjøre folkevalgt organ. Folkevalgt organ skal styre virksomheten og skjønne sin rolle i forhold til administrasjonen Det handler om å gi styringsorganet muligheter for styring og kontroll gjennom økonomirapporter, HMS-rapporter mv., men også om å utvikle arbeidsgiverpolitikk, gravferdspolitikk osv. som gir strategisk utvikling og styring og som administrasjonen skal følge opp.

Jeg har påpekt med henvisning til Bjørnå og Schmidt at det kirkelige demokratiske system er en spesiell variant, men har mest til felles med et det lokale kommunale demokrati. Grunnpilarene i dette demokratiet er at de folkevalgte organene fatter vedtak, bestiller og kontrollerer. Politikernes rolle er å

- stille krav

- gi armslag

- spørre etter resultater underveis

- markere støtte når det er behov for dette

- evaluere resultater grundig og redelig

- ivareta medbestemmelse og medinnflytelse (Kommunesektorens organisasjon [KS], 2017, s. 25)

\section{Konklusjon}

En sentral del av verdidebatten i det kirkelige demokratiet handler om lokale fellesskap. I dette perspektivet har kirken hentet mye og har fortsatt mye å hente i kommunitaristisk teori om vedlikehold av lokalt fellesskap og lokal identitet. Det peker også på behovet for lokalt handlingsrom for å øke engasjement og deltakelse. De pågående utredninger om fremtidig kirkelig organisering finner sterke likheter mellom statens behov 
og sentrale kirkelige organers behov for minimum av likheter i tjenestetilbud.

En ytterligere utvikling av de lokale rådsorganene gjennom økt ansvar og handlingsrom vil gi styrket vitalitet og engasjement. Det er viktig å se på lokalsamfunnet primært som borgere og ikke som brukere, selv om kirken må være opptatt av menneskenes individuelle behov.

Mens det sekulære demokrati er bygget på stemmerett og borgerrett, er det kirkelige demokrati bygget på det medansvar for kirken som springer ut av dåpen (Askeland, 2003; Grimstad, 1999; Hegstad, 2009, 2019). Forutsetningen for demokratiet som bærende styringsform i kirken er en $ø k t$ forståelse for forpliktelsen som døpt medlem av trossamfunnet.

For kirken vil det være å skape arenaer for utvikling av synspunkter og ståsteder der lekfolket i dialog med embetsbærere legger til rette for diskursen. En levende demokratisk folkekirke forutsetter en levende teologisk debatt i et herredømmefritt rom. Den tydeliggjøringen av «Kirkens grunnlag» som er gitt gjennom $\$ \$ 1$ og 2 i Kirkeordningen gir både en mulighet for økt bevissthet og refleksjon, men innebærer også en fare for at «vokterrollen» kan gi mindre mulighet for like muligheter til opplyst forståelse.

Kirken er først og fremst lokal. Overordnede styringsorganer skal tjene det lokale. Den lokale kirke er ikke et avdelingskontor av den nasjonale kirke (Andresen, 2015). Selvstendighet og oppgaveløsning ut fra lokale behov og lokale prioriteringer må vektlegges. Tillit, og ikke kontroll, skal kjennetegne samspillet mellom lokale og sentrale/regionale organer. Arven fra kongestyret må erstattes av likeverdighet og partnerskap

Demokrati handler om kultur mer enn valgordninger. Den demokratiske kultur er preget av åpenhet, profesjonell saksbehandling og ledelse og et nødvendig skille mellom politikk og administrasjon. Sentralt i bygging av demokratisk kultur er hvem som setter dagsorden, hvordan uenighet takles og tillit til saklig og likeverdig behandling. Dette krever rolleforståelse og kompetanse.

Ut fra den overordnende vurdering av utviklingstrekk i kirken som organisasjon ut fra demokratisering, organisasjonsgjøring og profesjonalisering, kan det også reises spørsmål om det er trender og utviklingstrekk som står i motsetning til hverandre - f.eks. demokratisering og profesjonalisering 
(Repstad, 2020, s. 148), der stadig nye oppgaver overtas av lønnede medarbeidere. Så langt er det denne forfatterens oppfatning at dette er en mulighet, men at det ikke er en stor fare for det demokratiske system i kirken. Det er primært en utfordring for den daglige ledelse og utformingen av den handlingsorganisasjonen som skal bidra til å utføre det demokratisk valgte har ansvar for. Jeg tror så langt at den danske teologen Theodor Jørgensen fortsatt har sine ord i behold når han påpeker at de reformatoriske kirker ikke har gitt det allmenne prestedømme som begrep den viktighet det tilsier og at det fortsatt vil være et stykke til at «begrep og viktighed dækker hinanden» (Jørgensen, 1993, s. 53ff.).

Hvordan styrer et kirkelig demokratisk organ? Ved opprettelsen av soknet som eget rettssubjekt skilt fra kommunen og med egne demokratiske organer, ble demokratiidealer fra kommuneverden lagt til grunn for kirken. Det innebærer et tydelig skille mellom politikk og administrasjon, blant annet ved lovfestet daglig leder som forventes å ha kompetanse på de saksområder som er tillagt organet. Sakslistekontroll fra leder av menighetsråd og fellesråd sier noe om rollefordeling og maktforståelse.

Demokratiet er en tjenlig styringsform i kirken og er i tråd med en grunnleggende forståelse av gudsfolkets ansvar for sin kirke. Utfordringen vil være å få engasjement for de store utfordringer og utviklingstrekk slik at det blir meningsfullt å skape en fremtid i fellesskap (Grimstad, 2005, s. 21).

«Speilingen» mot demokratiteori har vist at kirken har potensiale for videre utvikling gjennom å høste lærdom fra den allmenne teori. Det vil gi dypere forståelse av behovet for handlingsrom lokalt, god balansering av styringsformer og tilbakeholdenhet i overstyring.

Som svar på det forskningsspørsmål som er reist i denne artikkelen kan dette konkretiseres som behov for videre forskning og utredning på:

- Om legitimiteten i det kirkelige demokrati kan styrkes ved klarere rolleforståelse og tydeliggjøring av folkevalgtes styringsmulighet. Samvirke mellom den ordinerte tjeneste og de demokratisk valgte skjer $i$ rådet.

- Hvordan rollen som demokratiets vokter og tjener kan styrkes og hvilket ethos som i praksis preger kirkelig ledelse og forvaltning. 
- Utvikle folkevalgtrollen/lederrollen i kirkelige organer ved å gi handlingsrom for politikkutvikling og kontakt med borgere.

- Utvikle tydeligere rammer for prestetjenesten i rådene gjennom å tydeliggjøre forholdet mellom teologi og intern interessepolitikk.

- Styrke forståelsen av at det kirkelige tilsyn forankres i og skjer på vegne av fellesskapet.

Gjennom artikkelen har jeg pekt på det kirkelige demokratiets begrunnelse og særtrekk. Det er også pekt på svakhetspunkter i forhold til allmenn demokratiteori.

Det er innledningsvis pekt på at det kan etterspores demokratibølger og motbølger. Det kirkelige demokrati har klare innslag av dette, om enn noe «faseforskjøvet». Jeg har også pekt på uklarheter og motkrefter for det kirkelige demokrati. Den nylig vedtatte Kirkeordning for Den norske kirke kan ha elementer av dette. Det er viktig å kritisk følge utviklingen for å bygge et slitesterkt kirkelig demokrati der rådsorganer ikke blir «ornamenter» $i$ en utvikling der den egentlige makt ikke ligger hos demokratisk valgte, men i den tunge tradisjon med kirkelige embetsbærere.

\section{Referanser}

Andresen, K. (2015). Foredrag ved 25-års jubileum for KA. Upublisert.

Askeland, H. (2001). Den kirkelige rådsstrukturens teologiske og demokratiske legitimitet: Trekk av meningsbrytninger i siste del av forrige århundre. I J. O. Ulstein, P. M. Aadnanes \& O. Berge (Red.), "Jeg gikk meg over sjø og land ...»: Festskrift til Ottar Berge på 65-årsdagen (s. 267-289). Tapir.

Askeland, H. (2003). Hva betyr det om kirken forstås som organisasjon? I M. H. Hougsnæs, F. Grimstad \& H. Askeland (Red.), Ledelse i kirken (s. 23-42). KA Kirkelig arbeidsgiver- og interesseorganisasjon.

Bjørnå, H. (2005). Demokrativerdien i det lokale selvstyret. Kommunal Ekonomi och Politik, 9(4), 37-57. http://hdl.handle.net/2077/20688

Cohen, C. (1971). Democracy. University of Georgia Press.

Grimstad, F. (1999). Fra prestekirke - til rådskirke - til profesjonskirke? Tidsskrift for Teologi og Kirke, 43-53.

Grimstad, F. (2001). Om lojalitet og luthersk identitet i «En evangelisk luthersk folkekirke» KA Perspektiv, 2. 
Grimstad, F. (2005). Kirken - mellom hierarki og demokrati. I M. H. Hougsnæs (Red.), Den norske kirke - for folk flest. KA Kirkelig arbeidsgiver- og interesseorganisasjon.

Grimstad, F. \& Askeland, H. (1999). Den lokale kirkes styrmenn og -kvinner sitter de ved roret? I M. H. Hougsnæs (Red.), Kirken, lekfolket og presteskapet. Kirkeliv og kirkereformer i Den norske kirke ved årtusenskiftet (s. 40-58). Kirkens Arbeidsgiverorganisasjon.

Hegstad, H. (2009) Den virkelige kirke. Bidrag til ekklesiologien. KIFO-perspektiv. Tapir Akademisk forlag.

Hegstad, H. (2019). Dåpen - en nådens kilde. Verbum Akademisk.

Holbæk, J. A. (2019). Rådet som forandret kirken. Kirkerådet 50 år. Verbum.

Hougsnæs, M. H. (2005). Embete og råd - status etter Kirkemøtet 2004. I M. H. Hougsnæs (Red.), Den norske kirke - for folk flest. KA Kirkelig arbeidsgiver- og interesseorganisasjon.

Hougsnæs, M. H. (2011). Folkekirkens framtid. Nytt Norsk Kirkeblad, 39(5), 37-43. https://www.tf.uio.no/forskning/publikasjoner/nytt-norsk-kirkeblad/nnk-i-pdf/ nnk-2011-6.pdf

Indstilling og besludning O No 56. (1869). www.stortinget.no

Johnsen, J. P. (2017). Stat og kirke 2017 - en selvstendig folkekirke. Kirke og Kultur, (1), 73-86.

Jørgensen, T. (1996). Det alminnelige proestedømme og det folkekirkelige demokrati. Anis.

KA arbeidsgiverorganisasjon for kirkelige virksomheter. (2015, 24. april). Stillingsbeskrivelser - veiledningshefte for kirkelig fellesråd og menighetsråd. https://www.ka.no/sak/article/1190731

Kirkeordning for Den norske kirke. (2019). Kirkeordning for Den norske kirke (FOR-2019-03-30-2307). Lovdata. https://lovdata.no/forskrift/2019-03-30-2307

Kirkerådet. (1987). Kirkens embete \& råd: Hvem skal bestemme hva - og hvorfor? Utredning fra en arbeidsgruppe oppnevnt av Kirkerådet. Den norske kirke.

Knutsen, C. H. (2021). Demokrati og diaktatur. Fagbokforlaget.

Kommunesektorens organisasjon. (2017). Håndbok for ordførere. https://www.ks.no/ globalassets/fagomrader/for-deg-som-folkevalgt/handbok-for-ordforerenettversjon-endelig.pdf

Kultur- og kirkedepartementet. (2008, 13. mai). Styrket demokrati i Den norske kirke Innstilling fra en arbeidsgruppe oppnevnt av Kultur-og kirkedepartementet 13. februar 2008. KKD. https://www.regjeringen.no/globalassets/upload/kkd/kirke/v0942b_styrket_demokrati_i_den_norske_kirke.pdf?id=2228062

Lundquist, L. (1998). Demokratins väktare: Ämbetsmännen och vårt offentliga etos. Studentlitteratur AB.

NOU 1985: 21. (1985). Den norske kirke og loeren. Kirke- og undervisningsdepartementet. 
Nødland, S. I., Lindøe, P. H., Holmen, A. K \& Blomgren, A. (2014). Samstyring $i$ ubalanse. Evaluering av den lokale kirkes ordning (Rapport IRIS 2014/054). Kulturdepartementet. https://www.regjeringen.no/globalassets/upload/kud/kirke/ rapporter/sluttrapport_den_lokale_kirkes_ordning_2014.pdf?id=2240329

Rafoss, T. W., Aagedal, O., Larsen, E. N. \& Rønningen, N. M. (2020). Et demokrati $i$ endring. Analyse av kirkevalget 2019. KIFO.

Rasmussen, T. (2005). Fra reformasjonen til 1814. I B. T. Oftestad, T. Rasmussen \& J. Schumacher (Red.), Norsk kirkehistorie. Universitetsforlaget.

Rasmussen, T. (2017). Hva er protestantisme? Universitetsforlaget.

Rennison, B. W. (2004). Ledelsesbegrebets historie i den offentlige sektor. I D. Pedersen (Red.), Offentlig ledelse i managementstaten (s. 85-103). Samfundslitteratur.

Repstad, P. (2020). Religiøse trender i Norge. Universitetsforlaget.

Rødahl, G. (1988). Rådskirken tar form. Kirkerådet.

Saglie, J. \& Segaard, S. B. (2011). Den norske kirkes demokratiske legitimitet erfaringer fra kirkevalget 2009. Norsk Statsvitenskapelig Tidsskrift, 27(3), 155-178. https://www.idunn.no/nst/2011/03/arto3

Schmidt, U. (2011). Evaluering av demokratireformen i Den norske kirke (Sluttrapport). KIFO-rapport nr 4/11 http://www.kifo.no/wp-content/uploads/2016/o9/ Sluttrapport-Evaluering-demokratireformen.pdf

Schmidt, U. \& Mogstad, S. D. (2010). Når alle stemmer teller ... Evaluering av demokratireformen i Den norske kirke: Kirkevalget 2009. Det teologiske menighetsfakultet \& Stiftelsen Kirkeforskning. https://evalueringsportalen.no/ evaluering/naer-alle-stemmer-teller--evaluering-av-demokratireformen-i-dennorske-kirke-kirkevalget-2009

St.meld. nr. 17 (2004-2005). Makt og demokrati. Statsministerens kontor. https://www.regjeringen.no/no/dokumenter/stmeld-nr-17-2004-2005-/id406399/ Tjenesteordning for biskoper. (2016). Tjenesteordning for biskoper (FOR-2016-04-111812). Lovdata. https://lovdata.no/forskrift/2016-04-11-1812

Trossamfunnsloven. (2020). Lov om tros- og livssynssamfunn (LOV-2020-04-24-31). Lovdata. https://lovdata.no/lov/2020-04-24-31 



\title{
KAPITTEL 6
}

\section{Institusjonelle rammer for kirkelig ledelse}

\section{Frank Grimstad}

\author{
VID vitenskapelige høgskole
}

\begin{abstract}
Management can hardly be understood irrespective of the context in which it unfolds. This is also the case with ecclesiastical leadership. Nevertheless, the management literature has rarely incorporated how different aspects of context affect management. This chapter thematizes the public frames and regulations civil society and church/religious organizations operate within and discusses how this affects leaders' maneuvering space. An underlying premise of the chapter is that churches and religious organizations are institutions and that society as context is characterized by institutionalized frameworks framing religious organizations. Examples of this in a Norwegian context are the Working Environment Act and other laws governing working life, agreements negotiated between the parties in the labor market, and more specifically the Lutheran folk church tradition. Based on Scott's (2008) analytical approach to analyzing institutionalization, regulatory, normative and cognitive/cultural norms, the chapter discusses how leaders' maneuvering space is shaped by these mechanisms yet also has the ability to influence existing frameworks.
\end{abstract}

Keywords: cognitive, culture, institutional frames, law, leadership, maneuvering space

\section{Introduksjon}

Ledelse kan vanskelig forstås uavhengig av den konteksten den skjer innenfor, og dette gjelder naturlig nok også kirkelig ledelse. Innenfor generell ledelseslitteratur er det sjelden tematisert hvordan ulike sider ved kontekst preger ledelse. Bidragene som tar opp ledelse som praksis, søker derimot i større grad å inkludere kontekst (Meier, 2013; Mintzberg, 2009). Oftest vil det være de nære omliggende sektor-, fag- eller interorganisatoriske forhold som vektlegges, men vi ser i nyere tid også 
øt oppmerksomhet på institusjonelle rammer (Askeland et al., 2020; Kraatz \& Block, 2017). En tidlig institusjonell tilnærming var opptatt av legale rammer, mens nyere bidrag i større grad har vektlagt normative og kulturelt-kognitive rammer. Samtidig ser vi en voksende rettsliggjøring av organisasjoners ansvar og virksomhet, noe som særlig gjør det legale perspektivet interessant å forstå og diskutere.

Dette kapitlet peker på fraværet av refleksjonen omkring rammer, med særlig fokus på det legale. Jeg argumenterer for at betydningen av legale rammer er underkommunisert i ledelsesprosessen. Det legale er i hovedsak trukket inn hos enkelte teoretikere med forståelse av handlingsrom (Jacobsen, 2019; Jacobsen \& Thorsvik, 2007). Den norske kirke er i en endringsprosess der kirken de siste tjue årene mer og mer fremstår som en landsdekkende og demokratisk evangelisk-luthersk folkekirke, slik lovverket (Trossamfunnsloven, 2020) definerer kirken. Det er denne konteksten, med legale bestemmelser, som er med på å definere organisatoriske rammer og hva slags styring og ledelse kirken skal ha. Gjennom større reformer de siste tiårene trer kirken frem som en tydeligere korporasjon og aktør i sivilsamfunnet. Dette kapitlet drøfter hvilke rammer som kirken opererer innenfor og som legger føringer for lederes handlingsrom. Et underliggende premiss for kapitlet er at kirker, og øvrige religiøse organisasjoner, kan forstås som institusjoner, og at samfunnet som kontekst er preget av institusjonaliserte rammer som de må operere innenfor.

Kapitlet reiser følgende spørsmål: Hvordan preger institusjonelle rammer kirkelig ledelse, med sæerlig vekt på legale rammer, grunnlag og handlingsrom for kirkelige lederroller? Hvordan preger endringer i institusjonelle rammer kirkelig ledelse?

Det legale grunnlag for organisering og ledelse fremstår særlig innenfor ett sett med regulative rammer for den kirkelig virksomhet: den alminnelige lovgivning, den offentligrettslige lovgivning og den kirkerettslige lovgivning. Artikkelen presenterer og presiserer hvordan organisasjonsteoretikeren Richard Scotts inndeling i regulative, normative og kulturell-kognitive pilarer i institusjoner kan anvendes for å forstå grunnlaget og handlingsrommet for kirkelige lederroller (Scott, 2008). Dette skjer ved at sider ved lovgivning som særlig berører organisasjoner og ledere, drøftes med henblikk på hvordan de ulike pilarer enkeltvis og sammen former lederrollen. 


\section{Institusjonelle elementer former lederrollen}

Tradisjonelt har institusjonell teori i hovedsak rettet søkelyset mot tilpasning til institusjonelle mønstre i konteksten gjennom kognitive modeller, imitasjon og regulering. Dette har medført at forklaringsmodellene i liten grad inkorporerte aktørperspektivet. Nyere bidrag søker derfor igjen å reintegrere aktør og aktørskap for å forstå bedre hvordan institusjoner etableres, vedlikeholdes og endres (Lawrence \& Suddaby, 2006). Når temaet for kapitlet knyttes til institusjonelle rammer for lederes jobb, blir det nettopp sentralt å forstå både den frihet og den binding som ligger til lederes jobb. Selv om institusjonelle rammer legger føringer på lederes rolle og handlingsrom, må de også tilkjennes handlingsrom knyttet til fortolkning av situasjon, skjønnsmessige vurderinger samt et handlingsrom for beslutninger (Askeland, 1998).

Selv om institusjonell teori ikke er en samlet tilnærming og også har utviklet nyere perspektiver underveis, er det påpekt at det kan gjenfinnes noen sentrale faglige elementer. Scott (2008, s. 48) definerer institusjoner slik: «Institutions are comprised of regulative, normative and cultural-cognitive elements that, together with associated activities and resource, provide stability and meaning to social life.»

Med dette som felles fundament, vil ulike teorier og perspektiver variere rundt mer velkjente dikotomier: aktør versus struktur, rasjonelle versus fortolkende perspektiver, samt hva som er et naturlig nivå for institusjonelle analyser. Samfunnsvitere fra flere ulike fag har hatt institusjoner som utgangspunkt for sin forskning og teoretisering. Institusjonelt orienterte $ø$ konomer var opptatt av indeterminisme fremfor determinisme, eksterne fremfor interne forklaringsmodeller, samt at økonomiske regimer og systemer måtte forklares via historiske og komparative studier i stedet for å etablere strikte modeller over økonomisk ekvilibrium. Blant statsvitere var særlig etableringen av politiske institusjoner, fra legale systemer til etablering og vedlikehold av administrative enheter, et tydelig orienteringspunkt. Forklaringsmodeller inkorporerte beskrivelsen av intrikate systemer av sammenflettede regler, rettigheter og prosedyrer. Denne interessen for institusjonelle strukturer ble senere erstattet av forklaringsmodeller basert på politiske atferdsmodeller samt teorier om rasjonelle valg. Den mest markerte faggruppen blant institusjonelle 
teoretikere har vært sosiologer, med røtter tilbake til fagets klassikere. Interessen for og linjene tilbake til klassikerne, ledet til tre hovedgrupper av teoridannelse (Scott, 2004, s. 409-411).

Det har det siste tiåret vært interesse for å forstå ledelse innen rammen av institusjonell teori (Askeland, 2016; Lindheim, 2020; Sirris, 2019b). En viktig gren av denne interessen berører forståelsen av ledelse, og er oftest knyttet til begrepet institusjonell ledelse (Selznick, 1957). Når kapitlet tematiserer institusjonelle rammer, vil det være mer nærliggende at teoretisk inspirasjon i denne artikkelen hentes fra institusjonell teori. Her legges det særlig vekt på W. Richard Scott (2008), men også en annen sentral organisasjonsteoretiker innenfor denne tradisjonen, Phillip Selznick (1957). Særlig Scott har gitt innsikt i viktige institusjonaliseringsmekanismer.

Styring er forstått som det å fatte strategiske og bindende valg for organisasjonen når det gjelder organisering, rammer og mål. Denne oppgaven ligger primært til styret, eller rådet, og angir de rammer som ledelse skjer innenfor. Ledelse har vært forstått som en prosess mellom en leder med formell posisjon og der ledelsesprosessen søker å oppnå resultater gjennom samspill med andre (Grimstad \& Askeland, 1996, s. 78-79). Det kan etter min oppfatning skje gjennom bevisstgjøring og refleksjon av den konteksten kirken styres og ledes på.

Ledelse kan, som nevnt innledningsvis, vanskelig forstås uavhengig av den organisatoriske konteksten ledelse utøves innenfor. På den ene siden påvirkes ledelsen av ledelseskonteksten, og på den annen side kan ledelse gjennom ulike disposisjoner påvirke denne konteksten (Selznick, 1957; Strand, 2007). Det er med andre ord en dynamisk og gjensidig relasjon mellom ledelse og ledelseskontekst. Dette tilsier at det å beskrive ledelseskontekster og hvilke utfordringer dette gir blir viktig. Med ledelse i denne artikkelen tenker jeg mer på roller enn personer. Ved å ta utgangspunkt i Selznick og Scott vil jeg forstå ledelse som

- å skape et menneskelig og moralsk fellesskap, eller for å bruke Selznick sitt utsagn om «to infuse values» $(1957$, s. 11), som uttrykk for det normative element

- å skape forståelse, mål og mening som uttrykk for det kognitive element 
- å skape formelle ordninger som sikrer målrettet arbeid, organisatorisk integritet og konfliktløsning som uttrykk for det regulative element

Rammer ledelsen skjer innenfor omfatter en god porsjon skjønn, da både regler og retningslinjer må fortolkes og anvendes på konkrete situasjoner. For det første innebærer det at skjønnsutøvelsen rommer et visst handlingsrom, og for det andre innebærer det at det derved også gis visse muligheter for å endre og påvirke rammene.

I økende grad er det vanlig å beskrive organisasjoner som hybride. Det betyr at organisasjoner ikke lenger er entydige byråkratier, foreninger, produksjonsorganisasjoner, foretak eller liknende, men inneholder strukturelle, kulturelle og prosessuelle elementer fra ulike organisasjonsformer. Så også med kirken, som henter styringsformer fra ulike tradisjoner. Disse hybride organisasjonene representerer andre og til dels nye ledelsesutfordringer. En fellesnevner ved mange reformer i offentlig sektor de siste 30 år er at de er sterkt inspirert av New Public Management, en retning som blant annet er kjennetegnet av import av prinsipper og teknikker for organisering og ledelse i næringslivet (Schmidt, 2015, s. 40). Utfordringen for ledelse i hybride organisasjoner vil være møtet mellom disse ulike logikker (Sirris, 2019a) eller institusjonaliserte prinsipper, og vil variere med

- avstanden; hvor forskjellige de ulike institusjoner er

- overlapping; hvorvidt institusjonene konkurrerer om å løse samme oppgaver eller er komplementære gjennom å løse ulike problemer

- det relative styrkeforholdet mellom logikkene

Hybriditet brukes normalt som ulike typer styringslogikker (Sirris, 2019a), primært management og profesjon. Det kan også i utvidet mening brukes om kulturer og tradisjoner. Diskusjonen om ledelse i kirken i en fremtidig kirkeordning handler langt på vei om å smelte sammen en lokal/demokratisk tradisjon og en mer statlig/hierarkisk struktur. Denne ledelsen av institusjonaliserte prinsipper handler for det første om svært forskjellige institusjoner, for det andre om til dels overlappende 
ansvarsområder, eksempelvis mellom prest og menighetsråd, og for det tredje om at det relative styrkeforholdet historisk sett er asymmetrisk.

\section{Innsikter fra Scotts modell}

Jeg velger med utgangspunkt i Scott (2008) å beskrive de ulike elementer som konstituerer organisasjoner som regulative, normative og kulturelt-kognitive. I et sammenfattende arbeid har Scott inndelt ulike retninger innenfor institusjonell teori i tre hovedgrupper: regulative, normative og kognitive (Scott, 1995, s. xiv). Dersom institusjoner ses som regulative systemer vil også kollektiver av aktører, som organisasjoner, ofte tillegges interesser som de søker å realisere. For å regulere slik interessekonflikt og -kamp utvikles normer og regler, med tilhørende mekanismer som iverksetter sanksjoner. Gjennom regulative prosesser blir de institusjonelle verdier og mønstre for handling overført til konkrete aktører i det sosiale felt. Disse normene vil aktører og organisasjoner dels tilpasse seg i egeninteresse, for å unngå sanksjoner og for å kunne forvente tilsvarende av andre aktører, og dels som følge av tvang eller nødvendighet. Normative teorier understreker at institusjoner er systemer med et normativt fundament, basert på felles normer, verdier og trosforestillinger (Scott, 2004, s. 410-411). I denne tilnærmingen blir verdier et sentralt element, da de er innvevd i selve det institusjonelle systemet. Følgen av dette er at organisasjoner styres av regler, og at aktører oftest ser seg som bærere og iverksettere av denne type normer og tatt-for-gitt atferd i henhold til det som er passende (appropriate) (March \& Olsen, 2004).

Det pekes også på en historisk tilnærming til institusjoner, i den forstand at organisasjoner/institusjoner forstås som historiske fenomener der selve organisasjonshistorien legger føringer for senere praksis og hvilke endringer som er mulige (Pierson \& Skocpol, 2002). I et kultureltkognitivt perspektiv vektlegges det at aktørene skaper bildet av verden. Perspektivet bygger på kunnskapssosiologi som beskriver hvordan kunnskap konstrueres i samtale og samspill, for så å objektiveres i en slik grad at det fremstår som noe eksternt som i neste omgang virker tilbake på aktørene som noe objektivt gitt (Berger \& Luckmann, 20oo). Ut fra dette fremstår institusjoner som delte forestillinger med kraft til å 
definere virkeligheten. På mikronivå skjer dette gjennom at aktører over tid utvikler en felles forståelse, en virkelighetsforståelse som formidles og vedlikeholdes blant aktørene.

Institusjonenes rolle blir derved å etablere meningsskapende strukturer for sosial handling, dvs. fellesstrukturer for det vi skal gjøre i fellesskap (Scott, 2008, s. 96).

Scott (1995, s. 56) legger til grunn at institusjoner består av tre grunnleggende elementer:

1. Meningssystemer og handlingsmønstre, som inneholder

2. symbolske komponenter (representative, konstituerende og normative), som

3. blir iverksatt gjennom regulative prosesser.

Scott har utviklet og videreutviklet denne modellen med regulative, normative og kulturelle pilarer eller søyler fra midten av 80-årene, ved en stadig utbygging av resonnementer og elementer. Jeg velger å bruke den sammenfatningen han bruker i 2008. Scott beskriver disse tre mekanismene (søyler og transportører) som jeg vil bruke i denne artikkelen på følgende måte i en skjematisk oversikt:

Tabell 1. Tre søyler og formende elementer i organisasjoner (Scott, 2008, s. 96: Three pillars and carriers of institutions. Forfatterens oversettelse og bearbeiding)

\begin{tabular}{llll}
\hline & Regulativ & Normativ & Kulturell-kognitiv \\
\hline Symbolske systemer & Regler & Verdier & Kategorier \\
& Lover & Forventninger & Typifikasjoner \\
& & Standarder & Skjemaer \\
Relasjonelle systemer & & Rammer \\
& Styringssystemer & Regimer & Strukturell \\
& Maktsystemer & Autoritetssystemer & isomorfisme \\
& & & (likedannet) \\
Aktiviteter & & Identiteter \\
& Kontrollere & Roller, jobber, rutiner, & Predisponering, \\
& Sanksjonere & vaner, repertoar av & mottagelighet, \\
& Forstyrre & kollektive handlinger & tilbøyelighet \\
& & & Skript (manus) \\
Artefakter & Gjenstander som & Gjenstander møter & Objekter som \\
& er i samsvar med & konvensjoner og & har/besitter \\
& spesifikasjoner & standarder & symbolsk verdi \\
\hline
\end{tabular}


Gjennom en tydeligere konkretisering kan disse tre mekanismene fungere som analytiske begreper. Samtidig er det ikke lett å trekke entydige grenser mellom dem, da også regulative elementer baseres på verdier som primært omtales innen den normative mekanismen. Til en viss grad vil en kunne legge til grunn at det er knyttet tydeligere sanksjoner til regulative enn normative mekanismer, og at det normative knyttes sterkere til verdier og det kulturelt-kognitive til ulike virkelighetsfortolkninger og meningsmønstre.

Institusjoner regulerer og begrenser atferd eksplisitt og direkte i form av lover, regler, økonomiske incentiver, kontroll og sanksjoner (Scott, 2008, s. 52). Slik regulering kan bestå i å premiere en bestemt type atferd, krav til saksbehandling eller regulerte måter å håndtere økonomisk styring på. Regulative elementer påvirker folks atferd og avgjør lederes handlingsrom (Jakobsen, 2019, s. 67ff).

Institusjoner påvirker også folks oppmerksomhet, opplevelse og forståelse av seg selv og sine omgivelser (Scott, 2008, s. 97). Mening skapes, bevares og endres kontinuerlig i interaksjon med andre (Berger \& Luckmann, 2000). Slike prosesser skjer innenfor omfattende normative systemer og symbolske rammeverk. Normative elementer innbefatter sosialt konstruerte kategorier som avgjør hva som er gyldig og relevant kunnskap og forståelse. Disse kategoriene anses ofte som tatt for gitt. Institusjoner hviler på et sett av verdier og normer som angir hva folk bør gjøre i gitte situasjoner og definerer hvilke plikter folk har i omgang med andre (Schein, 1985).

Kulturelle/kognitive elementer/systemer inkluderer her både verdier i betydningen av foretrukne utfall og normer om ønsket atferd. Slike normer kan være allmenne, mens andre kan være knyttet til bestemte roller De ulike elementene er ikke uavhengige av hverandre. Regulative, normative og kulturelle/kognitive elementer kan understøtte hverandre, men kan også bidra til å undergrave hverandre. Organisasjonsprinsipper vil ha større gjennomslag og større sannsynlighet for å overleve i den grad regulative, normative og kognitive elementer sammenfaller med og understøtter hverandre (Scott, 2008). 


\section{Hvordan bidrar elementene til å forme lederrollen?}

I det følgende vil jeg konkretisere og drøfte de ulike institusjonelle rammebetingelser for kirkelig ledelse med utgangspunkt i Scotts (2008) tredeling.

\section{Regulative elementer}

Den første og overordnede regulative rammen er jussen - læren om rettsreglene. Jussen gir uttrykk for hva samfunnet på demokratisk vis har vedtatt å holde for rett, og som lovgiver forventer at befolkningen skal holde seg til eller forventer gjort. Når lover vedtas er det for å virkeliggjøre verdier som har stor tilslutning i befolkningen (Molven, 2017, s. 185). Når det gjelder organisasjoner og utøvelse av ledelse, vil oftest juss som institusjonell ramme, med ulike rettsregler og forordninger, primært handle om arbeidsrettslige temaer. Samtidig vil det mer generelt også være legale og regulative mekanismer knyttet til avtaler, samt at det kan gjelde ulike legale rammer om organisasjonen er offentlig, halvoffentlig, ideell eller privat. Juristen Olav Molven peker på at ledere i økende grad må forholde seg til lovgivning som styrende faktor (Molven, 2017, s. 183). Dette innebærer for eksempel at organisasjoner pålegges å ivareta ulike typer ansvar og standarder, og at det ofte er bygget inn konkrete bestemmelser om leders ansvar.

En del lovgivning omfatter alle som driver en eller annen form for virksomhet. Det gjelder eksempelvis arbeidsrettslig lovgivning, ferielovgivning og likestillingslovgivning. Siden 1977 har dette ikke minst vært tilfelle med arbeidsmiljøloven, som regulerer alle organisasjoner med ansatte. Den gjelder også i sin helhet for kirken - med mindre loven selv gir hjemmel for å fravike de konkrete bestemmelsene. Loven definerer blant annet krav til forsvarlig arbeidsmiljø, krav til tilsettings- og oppsigelsesprosesser og definisjoner av og krav til arbeidstid og fritid. Kirkelige ledere, som leder i arbeidsgivers sted, forventes å kjenne dette og forholde seg til det. Det finnes visse unntak for kirkelige medarbeidere. 
Dette kan eksempelvis innebære rett, eller åpning for, positiv særbehandling i samlivsspørsmål, tillatelse til søndagsarbeid eller lignende.

Offentlig virksomhet - først og fremst stat og kommune - reguleres av en del tilleggslover. Særlig viktig er forvaltningsloven og offentlighetsloven. Dette er lover som skal sikre åpenhet i forvaltningen, krav til innsyn i saker til behandling mv. Siden Den norske kirke har vært statskirke frem til 2012, har disse lovene også regulert kirken som arbeidsplass og vært en viktig institusjonell rammebetingelse. Blant annet har dette hatt betydning for saksbehandling, beslutningsprosesser og tilsettingsprosesser.

En rekke spesiallover regulerer den enkelte bransje (som helse og skole), og det er slik for eksempel kirkeloven og gravferdsloven de siste tiår har regulert kirken som bransje eller sektor. At statskirken opphører innebærer ikke at denne type reguleringer opphører. Fremtidig vil det være Kirkemøtet som med hjemmel i lov etablerer regelverk for å regulere den kirkelige virksomheten. Tjenesteordninger, ulike virksomhetsregler og plantyper er eksempler på dette. Den deregulering som skjer av kirkelig virksomhet ved svekking av offentlig regelverk kan etablere nye rammer for ledelse, men kan også videreføre de rammer som har eksistert. Et eksempel på dette er Kirkemøtets vedtak i 2019 som viderefører en del offentligrettslige prinsipper som tidligere var vedtatt av Stortinget som interne regler i trossamfunn.

Arbeidsretten er en annen regulativ ramme som medfører at ledelsen $i$ en virksomhet er underlagt en rekke begrensninger og føringer i lover, forskrifter og annet regelverk. I tillegg følger det en rekke individuelle rettigheter og plikter av individuelle avtaler og tariffavtaler. Lovgivers formål med regelverket er blant annet å skape et godt og trygt arbeidsmiljø og legge til rette for fleksibilitet slik at arbeidsforholdet kan tilpasses den enkelte arbeidstakers forutsetninger og livssituasjon (Smedsvig, 2016, s. 182). Arbeidslivet er, som samfunnslivet for øvrig, i stadig utvikling. Trygghet i arbeidsforholdet skapes ikke bare ved at den enkelte arbeidstaker sikres, men virksomheten må ha rammevilkår som kan sikre utvikling og økonomisk trygghet for fremtiden.

Arbeidsgiver har en rett til å organisere, lede, kontrollere og fordele arbeidet blant de tilsatte i virksomheten. Denne kompetansen kalles 
ofte arbeidsgivers styringsrett. Den er ulovfestet - det betyr at du kan ikke slå opp i en enkelt paragraf for å finne den nedfelt. Styringsretten er begrenset av en rekke lover og avtaler som kan variere noe fra bransje til bransje. For eksempel vil kirkeretten ha regelverk som handler om krav til utdanning og vigsling til en del grupper tilsatte. Det er regelverk som en personalleder må vite om og forholde seg til som rammebetingelser. I tillegg finnes det en individuell arbeidsavtale som gir rammer for håndteringen av styringsretten (Smedsvig, 2016, s. 183).

Arbeidsmiljøloven er en grunnlov på arbeidsrettens område, og omfatter alle som har tilsatt personer til å utføre arbeid i sin tjeneste. Arbeidsrettslig lovgivning forplikter arbeidsgiver til å sikre forsvarlig arbeidsmiljø fysisk og psykisk, hindre/forebygge mobbing og trakassering osv. Dette kalles ofte arbeidsgivers omsorgsplikt. Lovgivningen gir også rammer og prosedyrer for oppsigelse og avskjed (Smedsvig, 2016, S. 185).

Offentlig innsyn i forvaltningen er et viktig prinsipp fastsatt i offentlighetsloven. Den fastslår at forvaltningens virksomhet er offentlig. Enhver kan kreve innsyn i en hvilken som helst sak. Dette gjelder sakspapirer, postlister, referater med mer. Det finnes en rekke unntak fra offentlighetsbestemmelsene, men disse må det henvises til. Som rammebetingelse er dette en viktig forskjell mellom Den norske kirke og andre tros- og livssynssamfunn.

Kirkeretten er en regulativ ramme som er særskilt for kirken. Kirkeretten omfatter i denne sammenheng flere kategorier bestemmelser:

- $\quad$ Det særskilte lovverk vedtatt av Stortinget som regulerer kirkelig virksomhet

- Regler vedtatt av Kirkemøtet i medhold av lov som bindende for organer og personer

Som bransjelovgivning regulerer disse lover interne organisatoriske forhold i kirken. Hvem bestemmer hva? Hvilke innsnevringer i arbeidsgivers styringsrett kan trossamfunnet vedta? Lovgivningen og regelverket legger også rammene for enkeltprofesjoner og hva som er biskopens rolle 
som tilsyn i virksomheten. Trossamfunnsloven (2020) regulerer rammene for ulike tros- og livssynssamfunn i Norge. Som ledd i dereguleringen av Den norske kirke har ikke kirken lenger egne lover. Virksomheten er regulert i et eget kapittel i den nye felles lov. Det betyr at kirken fortsatt har egen rettslig regulering av indre forhold i trossamfunnet (kap. 3, $\$ \$ 10-17)$. De rettslige rammene regulerer i hovedsak Kirkemøtets, og til en viss grad soknets, rettigheter og plikter. Kirkemøtet fastsetter kirkens organisering, liturgier, lære og alle kirkens gudstjenestelige bøker. Lovgiver slår fast at kirken skal være demokratisk og landsdekkende. Dette innebærer at Kirkemøtet får større rom til å fastsette det Scott omtaler som regulative rammer.

Den norske kirke har i flere hundre år vært innvevd i stat og kommune, og kirkelig tilsatte har vært offentlige tjenestemenn. Biskopen og prostene har vært embetsmenn. Den livssynspolitiske utvikling og avvikling av kommunekirke (1996) og statskirken (2017) har medført en deregulering av kirken som offentlig størrelse. De siste hundre år har Stortinget vedtatt flere og flere lover - både for enkelte profesjoner (kateket 1969, diakon 1986, organist 1967, klokker 1963) og kirkeordningslov (1953) for kirkelige organer for så å oppheve disse lovene og legge ansvaret inn under demokratiske organer (1996). I siste runde trakk staten seg tilbake og overlot disse organisatoriske spørsmål til kirken (2021). Det kan derfor sies at de rettslige institusjonelle rammer er i sterk endring. Denne utviklingen, der kirken mer og mer beveger seg ut av det offentlige og inn i det sivile samfunn, er viktig å forstå som rammebetingelse for organisering og ledelse. Fortsatt omfattes kirken av en rekke offentlige lover, men dette vil også gradvis endres.

Økonomi og forvaltningspolitiske regimer er også til stede som regulative elementer. De siste tretti årene har vært preget bl.a. av mål og resultatstyring og New Public Management (NPM). Ikke minst på grunn av kirkens innveving i stat og kommune preger dette handlingsrommet for kirkelige ledere. Ulla Schmidt (2015) har påvist at kirken ikke uten videre adopterer nye forvaltningspolitiske styringslogikker, men har et verdisett som til en viss grad oppviser «resistens» og tar det i bruk ut fra egne vurderinger. Schmidt har analysert blant annet trosopplæringsreformen og prostereformen og sett de i et større reformperspektiv i det norske 
samfunn, der NPM og "post-NPM» dominerer. Hun konkluderer med følgende:

At a general level they demonstrate how the translation of public reform ideas into a church setting implies modifying them to reduce conflicts with the key elements of church identity and history. One such key element, which reform ideas are modified according to, is the position and constitutive role of the local parish in the organizational structure of the church. (Schmidt, 2015, s. 53)

Kirkelig økonomi er todelt. Den lokale kirke finansieres i hovedsak ved kommunale bevilgninger, og det nasjonale rettssubjekt (Kirkemøtet) mottar statlig bevilgning til virksomheten i prestetjenesten og de sentrale og regionale råd. Dette er nå lovfestet i trossamfunnsloven kap. $3 \$ 14$. Den lokale kirke finansieres således fortsatt av kommunen, og er tett knyttet opp mot prinsipper i kommunal økonomiforvaltning. Det handler om budsjettprosessen og kommunens behandling av kirkebudsjettet. Den lokale kirke er regulert av egen forskrift om økonomiforvaltning (Forskrift om økonomiforvaltningen i sokn i Den norske kirke, 2020). Dette innebærer blant annet at den lokale kirke ikke kan gå «konkurs», men settes under administrasjon av bispedømmerådet. Den statlige finansiering av virksomheten i det nasjonale rettssubjektet er derimot regulert av regnskapsloven. Tilsvarende er kirkelig fellesråds planansvar og ansvar for kontakten med kommunen regulert av de lokale planprosesser i kommunen. Også når det gjelder hvem i kommunen som behandler kirkesaker og hvordan, varierer lokal kirkeforvaltnings kontakt med kommunen politisk og administrativt (Askeland \& Lemvik, 2001, s. 35ff).

\section{Normative elementer}

Det som ifølge Scott kjennetegner de normative elementer er knyttet til sosiale forpliktelser og bindende forventninger, med en tydelig kobling til verdier. Kirken er en slik normativ organisasjon og arbeidsplass. Kirkens og menighetens oppdrag er utgangspunktet for lederjobben. Kirken har normerende skrifter og står ikke fritt til å definere sitt oppdrag. 
Kirken er allikevel en mangfoldig arbeidsplass, der ulike stillinger og ulike personer har ulik grad av å være dedikert til det normative grunnlag. Dette vil også variere ut fra ulike «menighetskulturer og teologiske ståsteder.

Teologi som normativ ramme blir naturlig nok ikke utfoldet av Scott, men en rekke andre bidragsytere tematiserer dette (Carroll, 1991; Selznick, 1987). De fleste organisasjonsteoretikere som forsker på kirkelige lederroller legger til grunn at en forutsetning for legitimitet som institusjonell leder er det viktig å ha inngående kjennskap til og identifisere seg med de det normative grunnlag i kirken. Tilsvarende må en kirkelig leder ha kompetanse om, identifisere seg med og delta i de kirkelige kjerneprosesser (Askeland et al., 2003, s. 14).

Det normative element i kirkeorganisasjonen fremkommer i et vidt spekter av tekster, forventninger og ritualer. I tillegg til krav i medlemskap i trossamfunnet legges det i utlysningstekster vekt på lojalitet og engasjement for kirkelig virksomhet. For enkelte (sentrale) stillinger som har med forkynnelse, kirkelig undervisning, diakoni og kirkemusikk er det krav om å la seg «vigsles» til tjeneste. Ved vigsling tilkjennegir man en personlig forpliktelse til å lære og leve i samsvar med den kristne tro. Vigslingen av prest, kateket, diakon og kirkemusiker skjer normalt av biskopen og etter en fast liturgi. Vigslingen er å betrakte som et «løfte», og ikke en type kontrakt parallelt med den arbeidsrettslige. Selv om biskopen ikke er leder eller arbeidsgiverrepresentant for disse medarbeiderne, kan biskopen gi «bindende pålegg for utførelsen av tjenesten» (Tjenesteordning for biskoper, $₫ 1$ ) dersom de bryter det løftet de har gitt om å lære og leve i samsvar med den apostoliske lære. Diskusjonen om grad av normativitet og forpliktelse avspeiles også i diskusjonen om hvorvidt kirkekompetanse eller lederkompetanse er viktigst for å inneha en kirkelig lederstilling. Den teologiske normativiteten skal i den kirkelige organisasjon ivaretas av tilsynet representert ved biskopen i det enkelte bispedømme. Normativiteten skal opprettholdes via vigsling, visitas og å tegne teologisk profil i det offentlige rom. Biskopen har også hjemmel til å innkalle til samtale med enkelttilsatte - uavhengig av vigsling, der biskopen anser atferd i strid med normative elementer. Dette samsvarer med det Scott omtaler som normative regimer og autoritetssystemer. Det 
normative fremtrer også i forventninger til gudstjenestedeltakelse (Scott, 2008, s. 97) for kirkelige ledere og medarbeidere.

\section{Kulturelt-kognitive elementer}

Ifølge Scott påvirkes organisasjoner ikke bare av rettslige regulative mekanismer, men også av sosialt konstruerte kategorier som avgjør hva som er relevant kunnskap og forståelse. Disse kategoriene tas ofte «for gitt» (Scott, 2008). Jeg vil her se på to sett av slike rammer som danner grunnlag for konteksten ledelse av virksomhet i kirken skjer innenfor: «den norske modellen» og «strukturell isomorfisering».

Trepartssamarbeidet mellom stat, arbeidstaker- og arbeidsgiverorganisasjoner blir også kalt den norske eller nordiske modellen. Det er ikke entydig hva som ligger i den nordiske modellen, men noen kjennetegn som ofte trekkes frem som felles kjennetegn er høy sysselsetting, høy andel kvinner i arbeidsstyrken, sjenerøse velferdsordninger, små lønnsforskjeller, høy fagforeningsgrad og utstrakt samarbeid mellom partene i arbeidslivet (Olsen, 2016, s. 258). Norsk arbeidsliv, eller den norske arbeidslivsmodellen, handler om å

- balansere jobb og fritid

- balansere mellom det å yte på jobben og ta seg av ting som tilhører den private sfære

- balansere mellom arbeidstakers rettigheter og arbeidstakers plikter

Deltakelse og medvirkning handler om å kunne øve innflytelse (Olsen, 2016, s. 241) For ansatte er det viktig å kunne påvirke forhold som arbeidets innhold, arbeidsmiljø, nedbemanning og omstillinger. Det er viktig med gode relasjoner mellom leder, ansatte og organisasjoner. Slikt samarbeid er viktig lokalt i den enkelte virksomhet, men også mellom «parter» sentralt.

Partssamarbeid har lange tradisjoner i Norge. Modellen er preget av nærhet i kommunikasjon, hyppighet i kontakt og samarbeid i virksomhetene. Den har bidratt til stabilitet og ryddighet i lønnsforhandlinger, pensjonsordninger osv. Samarbeidsmodellen handler å definere spilleregler 
og samhandlingsmønstre (Olsen, 2016, s. 250). Det har medført at det er stor tillit i norsk arbeidsliv mellom arbeidsgivere/arbeidsgiverorganisasjoner, arbeidstaker/arbeidstakerorganisasjon og staten.

Arbeidsmiljøloven har kapitler som rettsliggjør standarder, mens avtaleverket (Hovedtariffavtale og Hovedavtale) legges «oppå» lovverket og regulerer rettigheter og medbestemmelse. Den norske modellen er knyttet opp mot sentrale organisasjoner både på arbeidsgiver- og arbeidstakersiden. Modellen er i en viss grad avhengig av organisasjonsgrad på begge sider. I Norge er organisasjonsprosenten på arbeidstakersiden ca. 50 \% og har vært synkende de siste årene (Olsen, 2016, s. 251).

Den norske modellen ble utsatt for en del kritikk i begynnelsen av 1990-tallet, men er i dag i medvind. Modellen er avhengig av dynamikk og evne til endring, og er hele tiden under debatt og utvikling. Både lokalt og sentralt setter modellen sterke krav til aktørene - tillit må skapes og gjenskapes, avtaler fornyes og moderniseres, ansatte og ledere må mobiliseres og engasjeres (Trygstad \& Hagen, 2007, s. 116).

Ved selvstendiggjøringen av kirken lokalt i 1997 og ved opprettelsen av KA, arbeidsgiverorganisasjon for kirkelige virksomheter ble kirken formelt en del av dette samarbeidet. Det har fått nedslag i lovverk og tariffavtaler (se Hovedavtalen). Tilsvarende skjedde da kirken sentralt ble selvstendig i 2017 og meldte seg inn i KA. Modellen er også «adoptert» av kirken og preger det relativt stabile arbeidet i utviklings- og endringsprosesser. Hovedutfordringer i kirken har vært mange små enheter å utøve medbestemmelse i forhold til, og lav organiseringsgrad for enkelte arbeidstakergrupper.

Til de kultur-kognitive «søyler» hører også det Scott (2008, s. 96) omtaler som strukturell isomorfisme. Det handler om at det skjer en prosess med likedanning med kulturen på den kirkelige arbeidsplass. Den norske ledelsesforskeren Brit Sund har i boken Typisk norsk å vore (selv) god (2019, s. 33) pekt på at når en leder tilpasser sin lederstil slik at den harmonerer med de verdiene medarbeiderne har, oppleves det positivt og støttende, og øker mulighetene for å lykkes. Poenget er at enhver leder i kirken vil bli møtt med forventninger om å tilpasse seg. Brudd på dette vil bli møtt med sanksjoner. I en organisasjon i endring vil dette være en krevende lederutfordring. Et eksempel er kirkens holdninger til LHBT+. 
En leder kan ikke unndra seg oppgaven det er å redefinere «hva vi vil i fellesskap» og tegne bilder som kan bryte med det tilvante. For LHBT+ manifesterer det seg både i ansettelsesproblematikk (de rettslige rammer), men også i ritualer og normative og kulturelle uttrykk.

\section{Konklusjon og utblikk}

Utgangspunktet for denne artikkelen var institusjonelle rammers tilnærmede fravær i en del av den aktuelle ledelseslitteraturen. Forståelse av ledelse er lite undersøkt ut fra regulative rammer. Med utgangspunkt i Scott (2008) har jeg søkt å belyse de rammer, primært legale, som legger sterke føringer på ledelse som utøves i ulike kontekster med vekt på det kirkelige.

Jussen som regulative ramme vil, sammen med felles avtaleverk, være en felles regulative normering. Vi har påpekt at endringer i institusjonelle rammer primært handler om endringer i offentligrettslige regler og større frihet for Den norske kirke til å lage sine egne «lover og regler» som en selvstendig korporasjon frikoblet fra stat og kommune. Det utfordrende vil være de normative faktorer ut fra hva som konstituerer religiøs ledelse.

Vi har gjennom dette vist at det å underkommunisere rammebetingelser gir et skjevt bilde av den ledelseshverdag kirkelige ledere står i. Samtidig vil den nye situasjonen potensielt kunne gi både kirken som organisasjon og den enkelte kirkeleder større mulighet til å forme omgivelser. I en ny situasjon vil institusjonelt lederskap måtte diskuteres og vurderes ut fra hva som er verdibevarende og identitetsskapende for kirken som helhet. Vi har påpekt de utfordringene som oppstår der regulative rammer erstattes av mer normative krav og forventninger.

\section{Referanser}

Askeland, H. (1998). Ledere og lederroller: Om ledelse og lederroller i den lokale kirke. Tapir.

Askeland, H. (2016). Ledelse og lederes rolle i Den norske kirke: Lederrolleundersøkelsen 2016 i et tyveårsperspektiv. Tidsskrift for Praktisk Teologi, 33(2), 5-19. https://journals. $\mathrm{mf}$. no/tpt/article/view/5197 
Askeland, H., Espedal, G., Løvaas, B. J. \& Sirris, S. (2020). Understanding values work: Institutional perspectives in organizations and leadership. Springer. https://doi.org/ 10.1007/978-3-030-37748-9

Askeland, H., Grimstad, F., Hougsnes, M. H. \& Lande, G. (2003). Ledelse i kirken. Kirkens arbeidsgiverorganisasjon.

Askeland, H. \& Lemvik, J. (2001). Planlagt utvikling: En veileder for lokalt kirkelig planarbeid. Kirkens Arbeidsgiverorganisasjon

Berger, P. L. \& Luckmann, T. (2000). Den samfunnsskapte virkelighet. Fagbokforlaget.

Carroll, J. W. (1991). As one with authority: Reflective leadership in ministry. Westminster/John Knox Press.

Forskrift om økonomiforvaltningen i sokn i Den norske kirke. (2020). Forskrift om økonomiforvaltningen i sokn i Den norske kirke (FOR-2020-12-08-2646). Lovdata. https://lovdata.no/forskrift/2020-12-08-2646

Grimstad, F. \& Askeland, H. (1996). Kirkelig ledelse. En ressursbok om ledelse i den lokale kirke. Kirkens Arbeidsgiverorganisasjon.

Jacobsen, D. I. (2019). Ledelse og den offentlige dimensjon. En sammenligning av ledere i offentlige og private organisasjoner. Fagbokforlaget.

Jacobsen, D. I. \& Thorsvik, J. (2007). Hvordan organisasjoner fungerer (3. utg.). Fagbokforlaget.

Kraatz, M. S. \& Block, E. S. (2017). Institutional pluralism revisited. I R. Greenwood, C. Oliver, T. B. Lawrence \& R. E. Meyer (Red.), The Sage handbook of organizational institutionalism (s. 532-557). Sage. http://dx.doi.org/10.4135/9781849200387

Lawrence, T. \& Suddaby, R. (2006). Institutions and institutional work. I S. R. Clegg, C. Hardy, T. Lawrence \& W. R. Nord (Red.), The SAGE handbook of organization studies (2. utg., s. 215-254). Sage. http://dx.doi.org/10.4135/9781848608030

Lindheim, T. (2020). «Good leaders do the dirty work»: Implicit leadership theory at the multicultural workplace. I H. Askeland, G. Espedal, B. J. Løvaas \& S. Sirris (Red.), Understanding values work: Institutional perspectives in organizations and leadership (s. 97-115). Palgrave Macmillan. https://doi.org/10.1007/978-3-03037748-9_6

March, J. G. \& Olsen, J. P. (2004). The logic of appropriateness. I R. E. Goodin, M. Moran \& M. Rein (Red.), The Oxford handbook of public policy. Oxford University Press. https://doi.org/10.1093/oxfordhb/9780199548453.003.0034

Meier, N. (2013). Between policy and practice: An investigation of clinical managerial work. Aarhus University.

Mintzberg, H. (2009). Managing. Berrett-Koehler.

Molven, O. (2017). Juss, etikk og styring. I E. Aadland \& H. Askeland (Red.), Verdibevisst ledelse (s. 182-205). Cappelen Damm Akademisk.

Olsen, K. M. (2016). Deltakelse og medvirkning. I A. Mikkelsen \& T. Laudal (Red.), Strategisk HRM 1 (2. utg., s. 241-267). Cappelen Damm Akademisk. 
Pierson, P. \& Skocpol, T. (2002). Historical institutionalism in contemporary political science. I I. Katznelson \& H. V. Milner (Red.), Political science: State of the discipline (s. 693-721). W. W. Norton.

Schein, E. H. (1985). Organizational culture and leadership. Jossey-Bass.

Schmidt, U. (2015). Church reforms and public reforms. I H. Askeland \& U. Schmidt (Red.), Church reform and leadership of change (s. 38-55). Pickwick Publications.

Scott, W. R. (1995). Institutions and organizations. Sage.

Scott, W. R. (2004). Institutional theory. I G. Ritzer (Red.), Encyclopedia of social theory, 11, (s. 408-414). Sage.

Scott, W. R. (2008). Institutions and organizations: Ideas and interests (3. utg.). Sage.

Selznick, P. (1957). Leadership in administration: A sociological interpretation. Row Peterson.

Sirris, S. (2019a). Coherent identities and roles? Hybrid professional managers' prioritizing of coexisting institutional logics in differing contexts. Scandinavian Journal of Management, 35(4). https://doi.org/10.1016/j.scaman.2019.101063

Sirris, S. (2019b). «The pastors' dilemma» revisited. Religious leaders connecting the spiritual and organizational realms through conceptual work. Journal of Management, Spirituality \& Religion, 16(3), 290-313. https://doi.org/10.1080/14766 086.2019.1574599

Smedsvig, T. (2016). Praktisk personalledelse i et rettslig perspektiv. I A. Mikkelsen \& T. Laudal (Red.), Strategisk HRM 1 og 2. Cappelen Damm Akademisk.

Strand, T. (2007). Ledelse, organisasjon og kultur (2. utg.). Fagbokforlaget.

Sund, B. (2019). Typisk norsk å vore (selv)god. Cappelen Damm Akademisk.

Trossamfunnsloven. (2020). Lov om tros- og livssynssamfunn (LOV-2020-04-24-31). Lovdata. https://lovdata.no/lov/2020-04-24-31

Trygstad, S. C. \& Hagen, I. M. (2007). Ledere i den norske modellen: Fafos rådsprogram 2006-2008 (Fafo-rapport 2007:24). https://www.fafo.no/media/ com_netsukii/20024.pdf 

Del II

Kirkelig ledelse 



\title{
KAPITTEL 7
}

\section{Ledelse - generelle og kirkelige perspektiver}

\section{Harald Askeland}

VID vitenskapelige høgskole

\begin{abstract}
The chapter introduces the field of management and leadership theory in general, outlining how the central terms and perspectives have evolved. At the same time, this chapter gives special emphasis to theories underlining management and leadership as work and practice, exploring and understanding the main divides of the field. The second part of the chapter summarizes and points to specific aspects in which church management and leadership overlap and differ from general management. The last section underlines the importance of how management is organizationally mandated, embedded in several institutionalized frames such as democracy, legal frameworks and the internal authority of oversight by the bishop. The chapter concludes by rounding out a wholistic understanding of the responsibility and aspects of management and leadership.
\end{abstract}

Keywords: church, leadership, management, organization, practice

\section{Introduksjon}

Hensikten med dette kapitlet er å gi en introduksjon til ledelsesfaget samt koble dette til kirkelige perspektiver. Kapitlet tar utgangspunkt i ledelse som en organisatorisk forankret funksjon, der fokus ligger på lederes jobb, roller og praksis. Ledere erfarer fort at det oppleves å være betydelig forskjell mellom beskrivelsen av ledelse i litteraturen, de ideelle forventninger som møter ledere i stillingsutlysninger eller ledelsesplattformer og den operative hverdag de står i. Forskning viser også at lederes hverdag er mer operativ, hektisk og kompleks enn det bildet som 
tegnes i tradisjonell ledelseslitteratur (Mintzberg, 2009), og tilsvarende funn er gjort med hensyn til ledelse i menigheter (Askeland \& Hansson, 2005; Sirris, 2013).

Det er flere grunner til å velge lederjobb og ledelsespraksis som perspektiv. For det første eksisterer det mange og delvis motstridende syn på hva ledelse er og hvordan det utøves eller bør utøves. De ulike syn har gjerne, uttalt eller ikke, forskjellig utgangspunkt for forståelse og studiet av ledelse. De fleste studier og fagbøker tar utgangspunkt i en individualistisk forståelse av ledelse, med vekt på hvordan ledere påvirker medarbeidere og bidrar til at organisasjoner oppnår sine mål på en mest mulig effektiv måte (Gardner et al., 2010; Tengblad, 2012). Brorparten av slike studier er basert på forskning av leder-medarbeider-relasjoner, der organisasjon og kontekst blir svakt betont. Andre studier tar utgangspunkt i hvilke oppgaver og funksjoner organisasjoner trenger å ivareta og utvikler modeller basert på funksjoner som ivaretas eller bør ivaretas (Cameron et al., 2006; Strand, 2007; Yukl, 2010). Felles for disse tilnærmingsmåtene er at de starter med en tese eller teori om hva ledelse innebærer, for så å undersøke hvordan ledelse samsvarer med disse dimensjonene. Disse ledelsesteoriene kan omtales som normative teorier, som både foreskriver god praksis og tenkes å være gyldige på tvers av organisasjoner, sektorer og kulturer.

Uavhengig av en faglig akademisk diskusjon om hva ledelse innebærer, går personer inn i organisatoriske lederroller og ivaretar funksjoner og oppgaver som organisasjonen, medarbeidere og de selv synes er naturlige og nødvendige. Kapitlet søker å bidra til å forstå lederrollen og hvordan den ivaretas og utøves i praksis. Fremstillingen bygger på at ledelse har innslag av både en individuell og en kollektiv dimensjon. Ledere bringer sin personlighet, sin faglige bakgrunn og sitt eget preg inn i det å fylle posisjoner og ivareta mandat og ansvar på vegne av organisasjonen. Dette ansvar er organisatorisk forankret, og det eksisterer dermed føringer og forventninger forut for og uavhengig av den individuelle leder. Ledere utøver sin jobb innen institusjonaliserte rammer, men med et visst (mer eller mindre omfattende) handlingsrom. En annen viktig grunn for å vektlegge lederjobben i praksis er at ledelse skjer i konkrete organisasjoner som løser konkrete oppgaver for å nå sine mål, og det skjer gjennom 
relasjoner til medarbeidere, preget av den kontekst eller situasjon der ledere jobber og utøver ledelse. Jeg vil argumentere for at selv om ledelse oppviser likhetstrekk på tvers av organisasjoner, vil man se variasjon ut fra den kontekst der ledelse utøves.

I over seks tiår har interessen for hva ledere gjør og hvordan de forsøker å lede gjennom hverdagslig praksis bygget opp alternativ innsikt i forhold til de mer normative og universalistiske teoriene. Gjennom observasjon av hva ledere gjør, gis beskrivende analyser av lederjobben, men også fortolkning av hva ledelse innebærer og hva ledere bidrar med for organisasjoner. Gjennom tidligere studier vet vi mye om hva ledere gjør. Det som er vanskeligere, er å tolke og integrere denne praksisen i faglig begrunnede teoretiske modeller (Hales, 1999; Mintzberg, 2009). Kapitlet vil derfor, med utgangspunkt i tidligere modeller og et norsk datamateriale, presentere bidrag som gir innsikt i lederes hverdagspraksis samt inviterer til å reflektere over hvordan ledelse kan ses som en integrert jobb.

\section{Ledelse - begrep søker mening}

Ledelse og lederskap har en faglig og forskningsmessig historie som er vel 100 år, og det foreligger ingen samlet eller enhetlig faglig kunnskapsstatus. Like fullt finnes det mange og viktige konseptuelle bidrag samt en omfattende forskningsinnsats som har generert betydelig innsikt. Vårt begrep om ledelse er historisk sett nokså nytt, da dette var lite egnet til å beskrive relasjoner $\mathrm{i}$ et tradisjonelt samfunn frem mot midten av 180o-tallet. Organisasjonspsykologen Jan Ketil Arnulf fanger situasjonen godt med følgende sitat:

Fram til 1844 foregikk nesten alt arbeid i verden for eierens regning og på eierens ansvar, med eieren som øverste sjef. I føydalsamfunnet kjempet soldater for sin lokale fyrste, som igjen måtte kjempe for konge og keiser. På jordene arbeidet folket for jordeierne, håndverkerne arbeidet for mesteren og prestene sto til ansvar for biskopen. Alle former for autoritet var grunnlagt $i$ arbeidets art som en diffus blanding av makt, tradisjon og lærdom. Derfor var ikke ledertitler transportable - man kunne ikke være oberst i kirken eller biskop i snekkerlauget. (Arnulf, 2012, s. 16) 
I Arnulfs fremstilling knyttes fremveksten av ledelsesbegrepet til aksjeselskapet, som en helt ny legal enhet og organisasjonsform ved etableringen og institusjonaliseringen av fenomenet «selvstendig rettssubjekt». Aksjeselskapet hadde som forutsetninger at eierskapet kunne omsettes, det hadde et ansvar begrenset til aksjekapitalen og alle medarbeidere inkludert lederen var ansatt. Fra det politiske liv beskrev Weber tidlig fremveksten av forvaltningsorganisasjonen, i form av byråkratiet, som innebar ansatte saksbehandlere og ledere. Også i mange av de større frivillige organisasjoner som vokste frem, ble det etter hvert ansatt medarbeidere og ledere i nasjonale og regionale sekretariater.

Noen trekk er felles for denne utviklingen: Det første viktige trekket er fremveksten av organisasjonssamfunnet, ved ulike former som selskaper, offentlig forvaltning og frivillige organisasjoner med egne sekretariater. Disse organisasjonene fremstod som korporasjoner i samfunnet, og de hadde legal status i form av å være rettssubjekter (Brunsson, 2011). De kunne dermed erverve eiendom, ansette medarbeidere og inngå i økonomiske kontrakter, og de hadde rettslig kapasitet til å saksøke og bli saksøkt. Det andre viktige trekket er at det over tid blir etablert en distanse mellom et økende antall eiere eller interessenter, i form av aksjonærer eller valgte representanter, og de som ivaretok den løpende drift av virksomheten. En fase der spesifiserte titler anga sammenheng mellom virksomhet og lederrolle, for eksempel som direktør, overlege, generalsekretær, ekspedisjonssjef eller forstander, bidro til en inndeling i det som omtales som generalistledelse, byråkratisk ledelse eller faglig ledelse (Døving, 2016). Den faglige og praktiske nytten av slike inndelinger synes å svekkes. De siste tiår har det skjedd en ytterligere rettsdannelse rundt lederjobben generelt og på tvers av sektorer, som ansvarlig virksomhetsorgan ved siden av styret, denne organisatorisk forankrete stillingen omtales både i arbeidsretten og ulike spesifikke lover som daglig leder. ${ }^{1}$

På hvilken måte har dette utgangspunktet betydning for diskusjonen om ledelse i samfunn, kirke og menighet i dag? Innsiktene til ledelsesfaget

$1 \quad$ Betegnelsen kom inn i kirkelig lovgivning første gang med kirkeloven av 1996, og var knyttet til lovfesting av stilling som daglig leder for kirkelig fellesråd (menighetsråd i ettsoknskommuner), men er nå gjennomgående betegnelse for lederstilling på alle nivåer i den nye kirkeordningen som ble vedtatt av Kirkemøtet i 2019. 
er i all hovedsak ervervet fra næringslivet. I forholdet mellom eierinteressene og daglig leder (direktør), vil ledelse innen aksjeselskapets logikk handle om ønskede resultater i form av avkastning eller effektivitet. Mye ledelsesteori har dermed handlet om å foreskrive hvordan man leder på en slik måte at man får mest mulig ut av de ressurser organisasjonen rår over (Arnulf, 2012, s. 20). For det første fokuseres prosessen mellom leder og medarbeidere, og mye ledelsesteori har dermed et individualistisk preg. Vekten ligger på lederen som aktør og på ulike måter å øve innflytelse på medarbeidere, for gjennom denne relasjonen å oppnå resultater gjennom andre. Blant annet er prosters lederrolle studert innen rammen av prinsipal-agent-teori, der leder som prinsipal søker å utforme styrings- og incentivsystemer som sikrer at agenten utfører arbeidet slik prinsipal (leder) ønsker (Huse, 1998). For det andre oppnås resulter i et marked og i konkurranse med andre, noe som leder til bruk av rasjonelle og strategiske grep for å oppnå konkurransefortrinn. Majoriteten av bidrag innen ledelseslitteraturen synes å behandle ledelse uavhengig av at organisasjonen har styrer som ansvarlige organer. Gjennom New Public Management har denne tilnærmingen vunnet innpass i statlig styring, og dermed indirekte i det tidligere statlige kirkestyret (dvs. geistlighet og sentrale og regionale kirkelige råd) (Askeland, 200o).

Når samfunnet i stadig sterkere grad fremstår som et fellesskap av organisasjoner, trenges det tilsvarende flere formelle ledere: Det vil si ledere som representerer og tar beslutninger på vegne av organisasjoner - både som intern funksjon og som ekstern kontakt og forhandlingspart. Her er det, ut fra bokens interesse for kontekst, nødvendig å skille mellom ulike typer organisasjoner. Både i offentlig sektor og i sivilsamfunnet vil ofte et representativt organ tilsette noen for å lede virksomheten i det daglige. I samfunnslivet vil borgerne velge sine representanter til å fatte bindende avgjørelser om rettigheter og plikter innenfor fellesskapet. For at det demokratiske organ skal sette sine mål, planer og vedtak ut i livet, trenger de en handlingsorganisasjon (forvaltningen eller administrasjonen) med tilsatte ledere. Som vi ser vil ledelse her være innebære å ivareta ledelse av virksomhet som ansvar, ut fra et gitt mandat. Leder vil være avhengig av eier(e)s, medlemmenes eller politikernes tillit. Ledelse fremstår mer som organisatorisk funksjon, autorisert av organisasjonens styrende organer. 
Dette fordrer faglige tilnærminger som fanger inn de strukturelle sider ved ledelse som funksjon, og samtidig åpner for at ledere også er aktører med handlingsrom (Askeland, 1998).

Med en mangfoldig ledelseslitteratur, øker behovet for en oversikt over de viktigste begreper og faglige posisjoner i litteraturen, ikke minst hvilke implisitte forutsetninger og verdier som ligger under ulike posisjoner og begreper. Mens mye ledelseslitteratur har vektlagt individualistiske og rasjonelle perspektiver, har andre lagt mer vekt på at ledere er innrammet av egen organisasjon og ivaretar roller innen den eksisterende strukturen. Idealtypisk kan dette fremstilles i en intensjonell og aktørorientert modell og en tydeligere strukturorientert rollemodell. Dette bidrar til å illustrere noen av ytterpunktene i ulike ledelsesteorier.

Tabell 1. Modeller av relasjonen mellom leder og organisasjon (bearbeidet etter Lotsberg, 1995)

\begin{tabular}{lll}
\hline Dimensjoner & $\begin{array}{l}\text { Intensjonell modell } \\
\text { (Aktørorientert) }\end{array}$ & $\begin{array}{l}\text { Rollemodell } \\
\text { (Strukturorientert) }\end{array}$ \\
\hline Aktørforutsetning & $\begin{array}{l}\text { Leder har handlefrihet og er } \\
\text { proaktiv }\end{array}$ & $\begin{array}{l}\text { Leder responderer på forventning } \\
\text { og er reaktiv }\end{array}$ \\
Strukturforutsetning & $\begin{array}{l}\text { Leder skaper eller drar nytte av } \\
\text { kontekst }\end{array}$ & $\begin{array}{l}\text { Kontekst tas for gitt og legger } \\
\text { føringer for leders valg }\end{array}$ \\
Handlingsbegrunnelse & $\begin{array}{l}\text { Leder handler for å realisere mål } \\
\text { og resultater }\end{array}$ & $\begin{array}{l}\text { Normen/forventning tilsier det, og } \\
\text { det ses som «passende» }\end{array}$ \\
Fokus for studier & $\begin{array}{l}\text { Personlighet, mål/resultat og } \\
\text { andre trekk ved leder eller } \\
\text { lederstil }\end{array}$ & $\begin{array}{l}\text { Dimensjoner i organisasjon og } \\
\text { leders rolle, plassering og mandat } \\
\text { i struktur }\end{array}$ \\
På jakt etter & Effektive lederstiler og lederatferd & $\begin{array}{l}\text { Strukturell regularitet og leders } \\
\text { bidrag til å balansere interesser }\end{array}$ \\
Handlingslogikk & Instrumentell & Normfølgende \\
Årsakssammenheng & Leder påvirker organisasjon & $\begin{array}{l}\text { Organisasjon påvirker leder } \\
\text { Leders bidrag }\end{array}$ \\
\hline
\end{tabular}

Tabellen viser en forenklet fremstilling av sentrale dimensjoner i disse modellene. Majoriteten av ledelsesstudier er forankret i en intensjonell modell, der aktøren tillegges betydelig handlefrihet for strategisk agering i forhold til konteksten (Lotsberg, 1995). Om den primære hensikt med ledelse er å skape resultater, blir rasjonalitet og intensjonalitet sentrale faktorer i lederatferd (Andersen, 2006). En annen, men mindre tradisjon, har lagt vekt på at mange faktorer er utenfor lederes kontroll og at de 
derfor kan antas å ivareta grunnleggende organisatoriske behov som tilpasning til kontekst, interne behov knyttet til koordinering og medarbeidere samt at organisasjonen leverer de resultater som forventes. Lederes roller (ofte et sett av rolleprofiler) og plassering i organisasjonen ses som avgjørende for det handlingsrom de har. Ikke minst legges det vekt på at organisasjoner er innvevd i institusjonelle rammer der både mål og virkemidler er påvirket av normative forventninger og ofte tatt for gitt (Pfeffer, 1977). Jeg vil argumentere for å innta en mellomposisjon, der det ikke er tvil om at ledere er forankret i organisasjoner og ivaretar sentrale funksjoner, men at de samtidig har et fortolkningsansvar og handlingsrom for å initiere forskjellige tiltak (Askeland, 2003a; Strand, 2007). Dette innebærer at ledere på samme tid både er innvevd i institusjonelle rammer som legger føringer, samtidig som de gjennom sin fortolkning og respons i praksis kan vedlikeholde eller utfordre de samme elementer. Lederes bidrag er dermed ikke enten effektivitet eller å ivareta gitte funksjoner, men at de kan like gjerne ses som en som tolker og kobler kunnskapselementer, som ved å redusere usikkerhet kan åpne handlingsrom.

\section{Styring og ledelse - som sentrale begreper også i kirkelig ledelse}

I engelskspråklig litteratur har det vært vanlig å operere med begrepene leadership, management og administration, etter hvert med vekt på de to førstnevnte.

Tabell 2. Sentrale ledelsesbegrepers etymologiske og innholdsmessige betydning

\begin{tabular}{lll}
\hline Begrep & Etymologi & Innhold i faglitteratur \\
\hline $\begin{array}{l}\text { Governance } \\
\text { Styring }\end{array}$ & $\begin{array}{l}\text { Gobernatio } \\
\text { Kyberneseis }\end{array}$ & $\begin{array}{l}\text { Representativt organ med styringsansvar for aktuell } \\
\text { virksomhet }\end{array}$ \\
$\begin{array}{l}\text { Leadership } \\
\text { Lederskap }\end{array}$ & Loedan & $\begin{array}{l}\text { Leder som går foran, formulerer visjon og samler } \\
\text { ressurser for felles innsats }\end{array}$ \\
$\begin{array}{l}\text { Management } \\
\text { Ledelse }\end{array}$ & Manus - Agere & $\begin{array}{l}\text { Leder som koordinerer organisatorisk handling mot } \\
\text { felles mål }\end{array}$ \\
Administration & Ad-Ministrare & $\begin{array}{l}\text { Systematisk oppfølging av mål og oppgaver iht. } \\
\text { vedtatte planer og normer }\end{array}$ \\
\hline
\end{tabular}


Leadership kommer antakelig fra et eldre angelsaksisk ord (loedan) som henspiller på evnen til å overbevise noen til å følge en et stykke vei (Grace, 2003). Begrepet leadership brukes dels om ledere i topplederstillinger, men også om selve det å øve innflytelse ved å gå foran samt å formulere visjoner og langsiktige mål som skaper tilslutning - altså makt til indirekte å dirigere organisasjonen. Dersom denne funksjonen ikke knyttes til den individuelle leder, men til kollektive, valgte organer, ligger det også nær begrepet styring som ofte brukes i offentlig sektor, med omtrent samme meningsinnhold. Vi snakker jo om både kommunestyret og menighetsrådet/fellesrådet som valgte styringsorganer. Styring er opprinnelig hentet fra det greske ordet for en styrmann på et skip (kyberneseis), og gjenfinnes i ordet for IT-baserte styringssystemer, kybernetikk. Styring kan ses som indirekte innflytelse gjennom målsetteringer, organisering og ressursprioriteringer. Management ligger nærmere det vi generelt vil forbinde med operative organisatoriske ledere. Forenklet får en dermed søkelys på forskjellige faktorer i forholdet mellom overordnede og underordnede og hvordan en kan planlegge og koordinere for produktivitet. En manager kan også dels oppfattes som en som holder styr på en kompleks, men samvirkende organisasjon. Rent etymologisk kommer begrepet ved en sammensetning av ordet for hånd (manus) og handling (agere), og var brukt om den som var hestetemmer (managgiero) på sirkus og kunne få en flokk av hester til å opptre koordinert i manesjen (Strand, 2007). Administration er i mindre grad i bruk, og relateres i stor grad til det som kan betegne den daglige operative utførelse av oppgaver ifølge fastsatte mål, regler og instrukser. Opprinnelig kommer det av preposisjonen for/ henimot (ad) og tjeneste (ministrare), og representerer den som gjør en tjeneste for eller henimot en hensikt (Frank, 2007).

Selv om det er tydelige forskjeller og nyanser i definisjoner i den omfattende ledelseslitteraturen, gis det også etter mitt syn en god del klare sammenhenger og sammenfallende elementer. Flertallet av bidrag og definisjoner fremhever at ledelse handler om sosiale prosesser der det utøves innflytelse overfor individ og gruppe. Dette hviler både på den formelle posisjonen og på den relasjon ledere evner å etablere med medarbeidere. Et annet vesentlig element er at ledelse innebærer at gruppens aktivitet og relasjoner struktureres i retning av å oppnå felles mål eller 
oppgaver (Askeland, 2013). Slik jeg ser det ligger det derfor en grunnleggende dimensjon knyttet til styring i lederskap.

Innen ledelsesfaget er det noe ulik forståelse av ledelse. Enkelte vil hevde at det er et grunnleggende skille mellom administrasjon, ledelse og lederskap (Kotter, 2001), mens andre vil hevde at det dreier seg om ulike sider eller dimensjoner ved ledelse (Strand, 2007). Omfanget av hver enkelt dimensjon og forholdet mellom dem vil primært avhenge av virksomhetens størrelse. Det som ikke finner støtte i ledelsesfaget, er å splitte opp lederansvar på en måte som fragmenterer ansvaret, for deretter å tilordne disse sidene ulike lederstillinger, linjer eller organer. Ledere har et helhetlig ansvar, men det er ikke til hinder for at ulike oppgaver (f.eks. faglig ledelse) kan fordeles eller eventuelt forankres i lovverk/retningslinjer til ulike stillinger.

Som andre bidragsytere, mener jeg at det er lite fruktbart å skille for skarpt mellom disse elementene. Lederskap, ledelse og administrasjon kan skilles analytisk, som forskjellige prosesser eller som ulike aspekter ved det å utøve ledelse, men vil inngå i ulike blandinger i lederes hverdag. I tilslutning til den kanadiske ledelsesforskeren Henry Mintzberg, som avdekket at enhver leder ivaretok mange og klare administrative oppgaver (Mintzberg, 1989), mener jeg det fornuftigste er å se administrasjon som en integrert del av det å være leder og utøve ledelse (Askeland, 2003a, 2016).

Selv etter oppløsningen av statskirkeformen, vil kirken og menighetene være tett koblet til offentlig sektor og offentlig regulering gjennom lover, tilskudd, planverk og kvalitets- og rapporteringsrutiner. Samtidig har det vært et aktivt valg fra kirken, og et klart politisk krav, at Den norske kirke skal være en landsdekkende og demokratisk forankret organisasjon. Kirken er dermed, som offentlig regulert virksomhet og i likhet med store deler av sivilsamfunnet, kirkepolitisk styrt ved sine representative rådsorganer. Det særegne i en kirkelig kontekst er at representanter for den særskilte tjeneste med ord og sakrament, er faste medlemmer av styringsorganet, og understreker at samvirke har utviklet seg som en integrasjon av aspekter fra den tidligere embetsmannskirken og utvikling av demokrati. Det er derfor hensiktsmessig å anvende et skille mellom styring(sroller) og ledelse(sroller). Begrepsmessig kan styring og ledelse forstås som ulike funksjoner: Styring kan forstås som det å fatte 
strategiske og bindende valg for organisasjonen på områder som overordnede rammer og mål, planlegging, ressursfordeling og avgjørelser knyttet til organisatorisk utforming av virksomheten. Ledelse kan da i sterkere grad betraktes som en prosess mellom den som er i en formell lederposisjon og medarbeiderne, der lederen ivaretar viktige organisatoriske funksjoner og der ledelsesprosessen søker å nå resultater gjennom samspill med andre (Askeland \& Grimstad, 1996, s. 78). En hovedtilnærming i forståelse av ledelse er altså å plassere det som en kontekstuell aktivitet, en aktivitet som er forankret i og rammet inn av den organisasjon der ledelse utøves.

\section{Forankring og utøvelse av ledelse: Ledelse og lederjobb i kirke og menighet}

For å tydeliggjøre hvordan ledelse både er institusjonalisert og rettslig regulert som en organisatorisk jobb og rolle, men også forankret i kirke og menighet som en særskilt kontekst, vil jeg peke på noen områder som kan være utgangspunkt for forståelse av lederskapets kirkelighet. Punktene som følger her vil bli relatert til fag- og forskningslitteratur, og også med vekt på noen av de særtrekk ved religiøse organisasjoner som er skissert i de innledende kapitler.

\section{Kirkens og menighetenes oppdrag er utgangspunktet for lederjobben}

Ut fra Den norske kirkes selvforståelse, formulert av Kirkemøtet, skal kirken være en åpen, inkluderende, tjenende og misjonerende kirke. Folkekirkens særlige oppdrag er å favne hele landet, møte alle medlemmer med kirkens tjenester og gi mulighet for delaktighet i utøvelsen av oppdraget. Dette er pekt på som et særtrekk ved kirkelige religiøse organisasjoner deres universelle ambisjoner favner vidt og fører ofte til enten et press på medarbeidere eller at tiltak får mer preg av å møte medlemmer primært ved sentrale livsfaser gjennom livsriter (Beckford, 1975).

En evangelisk-luthersk kirkeforståelse legger vekt på at kirkens oppdrag er gitt til menigheten med alle dens døpte medlemmer. Samtidig 
kalles medarbeidere til ulike og særskilte tjenester (Hegstad, 2009). Til disse hører også kirkelige lederoppgaver, forstått som en kirkelig tjeneste som springer ut av kirkens grunnleggende oppdrag. Den norske kirke ivaretar samtidig også oppdrag på vegne av samfunnet. Det gjelder særlig gravplassmyndigheten etter gravplassloven og kulturminneansvar etter kulturminneloven. Lederjobben på ethvert kirkelig forvaltningsnivå forutsettes å skulle håndtere både de kirkelige og de samfunnsmessige oppdrag som tilligger kirkelig forvaltning på det aktuelle nivået.

Mens det på den ene side er nødvendig å legge til grunn at allmenne egenskaper og funksjoner er sentrale i kirkelig lederskap, er det argumentert for at det å artikulere språklig hva som særmerker kirkelig ledelse, er sentralt. Et eksempel kan være den amerikanske teologen og sosiologen Jackson Carroll, som knytter det kirkelige lederskapets oppgaver til «a special concern for the preservation of the Christian identity of the community in constantly changing circumstances» (Carroll, 1991, s. 97).

Denne basale oppgave knyttes så sammen med teorier om institusjonelt lederskap (Selznick, 1957) og følgende grunnfunksjoner: 1) klargjøre organisasjonens oppdrag og mål, 2) virkeliggjøre dette formål i organisasjonens liv og virksomhet, og 3) bidra til at organisasjonen og dens medlemmer formulerer og fastholder grunnleggende verdier i møte med omgivelsene. Carroll formulerer på denne basis lederfunksjoner ut fra kirkens spesifikke kontekst:

Using these categories, we can construe the leadership task in a similar way: as meaning interpretation, which includes articulating the church's primary mission as the body of Christ, community formation, building organizational structures and relationships that express the church's Christian identity; and supporting the congregation's public ministry, helping the church and its members to live as Christ's body in the world. (Carroll, 1991, s. 99)

Mens konkrete oppgaver og funksjoner i lederjobben i stor grad har allmenne trekk som er like på tvers av samfunnssektorer, innebærer lederskapets kirkelighet samtidig en forankring i kirkens identitet og oppdrag, en forpliktelse på kirkens læregrunnlag samt evne til å artikulere og målbære folkekirkelige visjoner og målsettinger (Askeland, 2003b). 


\section{Den norske kirke - demokratisk styrte virksomheter}

Det er en forutsetning, ut fra politiske og kirkelige vedtak, at folkekirken er demokratisk med valgte styringsorganer på alle nivåer (Kirkerådet, 1987). Dette aspektet knytter ledelse til kirkens valgte styringsorganer, som henter sin legitimitet fra lovens bestemmelse om demokratiske strukturer og kirkeordning fastsatt av Kirkemøtet. Styringsorganene trenger rett og slett en handlingsorganisasjon med tilsatt leder, for å forberede og bidra til iverksetting av planer og vedtak.

Som det følger av ulike kirkelige utredninger, betyr dette at det samlede styringsansvaret for kirke og menighet ligger i de demokratisk valgte styringsorganer (Kirkerådet, 2001), slik det ble formulert av Kirkemøtet i vedtak om Kirkens embete og råd (Sak KM 19/88). Disse skal utføre sitt arbeid i lojalitet mot Den norske kirkes læregrunnlag.

I Den norske kirke som evangelisk-luthersk folkekirke forstås den særskilte tjeneste med ord og sakrament (embetet) prinsipielt ikke som en selvstendig styringsrolle ved siden av eller uavhengig av de valgte styringsorganer, men som integrert del av et samlet styringsansvar ut fra et samvirkeperspektiv. Siden midt på 1980-tallet har prinsippet om «samvirke mellom embete og råd» vært lagt til grunn for Den norske kirkes organisering. Det innebærer at det i alle demokratisk valgte råd, og på alle nivåer, er representanter for denne tjeneste. Disse inngår som fullverdige medlemmer i rådet, og tar som rådsmedlemmer del i styringsansvaret (Kirkerådet, 1987). Dette betyr også at rådene har styringsansvar for hele bredden i kirkens liv. I en nordisk kontekst har eksempelvis Svenska kyrkan en kirkeordning som opererer med tanken om «den dobbelte ansvarslinjen», der rådene og embetet har avgrensede og selvstendige ansvar (Hansson, 2001).

Et velfungerende demokrati er avhengig av en godt fungerende administrasjon for å utrede og følge opp vedtak (Grimstad \& Askeland, 1999). Samtidig er det nødvendig å etablere demokratisk kontroll over daglig leder / administrasjonen, og normalt vil dette skje gjennom delegasjonsreglement, årlig vurdering samt at rådets valgte leder er nærmeste overordnede mellom møter. Slik forstås demokratisk forankret ledelse som innordnet signaler, mål og rammer gitt av det valgte representative organet. 


\section{Kirkelige råd og vigslede medarbeidere er under biskopens tilsyn}

I kirkeordningen er biskopene tillagt et tilsynsansvar, noe som i hovedsak forstås i relasjon til å ta vare på den apostoliske lære og kirkens enhet gjennom forkynnelse, sakramentsforvaltning, råd og veiledning. Ved å være fullverdige medlemmer $\mathrm{i}$ rådet har biskopene del i det ansvar for nasjonal og regional styring som ivaretas av Kirkemøtet, kirkeråd og bispedømmeråd. De ivaretar videre lederoppgaver sammen med kirkelige ledere ved å representere kirken økumenisk, ved å visitere menighetene i bispedømmet, kvalitetssikre og godkjenne menighetenes sentrale planer samt ved felles uttalelser og initiativ.

Biskopen kan gi bindende pålegg vedrørende presters og andre kirkelige tilsattes tjenesteutøvelse, og skal særlig se til at vigslede medarbeidere bevarer sin tro og frimodighet i tjenesten. De skal også føre tilsyn med at de kirkelige råd i bispedømmet utfører sitt arbeid i lojalitet med den evangelisk-lutherske lære.

\section{Virksomhetene ledes av daglig leder}

Når et demokratisk valgt organ er tillagt oppgaver som skal løses i samfunnet, av et visst omfang og med tilsatte medarbeidere, trenger det valgte rådet en handlingsorganisasjon for å lede og utøve virksomheten.

Det overordnede ansvar for ledelsesfunksjoner i det daglige er normalt lagt til en daglig leder for den enkelte virksomhet. Det allmenne lovverk som regulerer virksomheter og arbeidsforhold, har oftest lagt til grunn at enhver virksomhet skal (eller kan) ha en daglig leder. Dette er konsekvent innarbeidet, også i kirken gjennom kirkeloven og videreført som et grunnprinsipp i kirkeordning vedtatt av Kirkemøtet i 2019 (Sak KM o6/19), gjeldende både for menighetsråd (kan bestemmes), kirkelig fellesråd, bispedømmerådene og kirkerådet.

Det sentrale ved denne samfunnsmessige og kirkelige regulering og forankring viser til at lederjobben er en organisatorisk forankret ansvars- og myndighetsposisjon, som utøves på vegne av det valgte rådet. 


\section{Arbeidsgiver utøver styringsrett ved virksomhetsledelse og arbeidsledelse}

Utgangspunktet for den kirkelige organisering er at soknet er kirkens grunnenhet med ansvar for sentrale kirkelige oppgaver. Fra og med 2017 ble Den norske kirke etablert som et selvstendig rettssubjekt. Samtidig er Den norske kirke et kirkesamfunn som etter lang historisk tradisjon har etablert tilsynsområder for større regioner (bispedømmer). Den norske kirke har utviklet seg som nasjonalkirke gjennom tusen år, og driver derfor også virksomhet på nasjonalt nivå. Rettslig sett inngår det regionale nivå i dag i rettssubjektet Den norske kirke.

For å ivareta ansvar for oppgaver har både rettssubjektet Den norske kirke og soknene etablert virksomhet og tilsatt medarbeidere for å utføre hele eller deler av virksomheten. Både på lokalt, regionalt og nasjonalt nivå styres Den norske kirke av demokratisk valgte organer, i likhet med øvrige organisasjoner i samfunnet. Disse består av eventuelle generalforsamlinger og styringsorganer. Til å ivareta styringsansvar i det daglige, tilsettes normalt en daglig leder.

Daglig leder er delegert det daglige ansvar for virksomheten som helhet. Er det behov for flere medarbeidere enn øverste leder, vil det å være arbeidsgiver inngå som en kjerneoppgave for daglig leder. Arbeidsgiver innehar styringsrett, definert som retten til å organisere, lede og fordele arbeid, samt inngå og avslutte arbeidsavtaler. Styringsretten som følger av å være arbeidsgiver kan sies å være en rett til å treffe bestemmelser både om arbeidsforholdet og om virksomheten (Fougner, 2019, s. 104f, 193f). Denne delingen, omtalt som arbeidsledelse og virksomhetsledelse, springer ut av den underliggende styringsrett som tilligger arbeidsgiver.

Den autonome kompetansen arbeidsgiver har til å treffe avgjørelser er mer omfattende mht. virksomhetsledelse enn arbeidsledelsen. Eier eller virksomhetsorgan (styre, menighetsråd osv.) vil, så lenge lov- og avtalefestede konsultasjoner er gjennomført, stå nokså fritt i avgjørelser om virksomheten. Arbeidsledelsen er mer regulert av lov, avtaleverk og ansettelseskontrakt, og medfører at styringsretten her blir noe tilsvarende begrenset. Arbeidsgivers styringsrett omtales derfor gjerne som en «restkompetanse». Ledelsesansvaret inngår like fullt som en integrert og vesentlig dimensjon ved arbeidsgiverrollen. 


\section{Dimensjoner i et helhetlig lederansvar}

I tråd med tidligere gjennomgang av de sentrale begreper, synes det på mange måter tilstrekkelig å anvende begrepene styring og ledelse som de sentrale analytiske begreper. Slik forstås administrasjon som en integrert del av ledelse. Samtidig er det et økende fokus på begrepet leadership, og jeg mener tilsvarende det er en del av ledelsesbegrepet. Men i denne sammenheng anvender jeg det mer i lys av institusjonelt lederskap (Selznick, 1957) enn den generelle lederskapslitteraturen (Rost, 1998). Fremfor å etablere et ytterligere skille i ledelsesbegrepet ved ulike typer dikotomier, for eksempel administrasjon og ledelse, ledelse og lederskap, fagledelse versus generalistledelse, argumenterer jeg i det kommende avsnitt for å holde ulike dimensjoner samlet $\mathrm{i}$ en integrert forstålse av ledelse som verdibevisst praksis.

Med hensyn til å forstå lederjobben som en organisatorisk forankret rolle med ansvar og tilhørende mandat, vil det være nyttig å knytte forståelsen av ledelse til ulike roller eller funksjonelle oppgaveprofiler som samlet konstituerer det å utøve ledelse (Askeland, 2015, 2017). Slike funksjoner knyttes gjerne til a) organiserende og administrative funksjoner; b) personal- og arbeidsgiveroppgaver; c) utvikling og tilpasning av faglige tjenester og oppgaver; d) nettverksbygging og forhandling. Samtidig vil kjernen i ledelse handle om å se helhet, bidra til fokus på formål og grunnleggende verdier samt få enheter til å fungere samlet slik at resultater oppnås.

Ledelse som praksis er langt mer dynamisk enn det som kan fanges inn ved de nevnte dimensjoner eller i ulike lederrollekategorier, og en vil også se at oppgaver veves sammen i et integrert hele. Om en følger Mintzberg har han arbeidet mer konkret med å samle innsikter i en integrert forståelse av lederes jobb og utøvelse i praksis (Mintzberg, 2009). Lederen har en sentral posisjon i organisasjonen, og har en vesentlig oppgave i å bidra til å skape en forståelse av organisasjonens mål og hensikt, noe som former lederens agenda av viktige saker og tiltak å jobbe med. Mintzberg peker på at ledelse i praksis utøves på tre plan som kan omtales som et informasjonsplan, et aktørplan og et handlingsplan. På alle disse tre nivåene utøves ledelse i relasjon til organisasjonen internt og det eksterne miljø (Askeland, 2016): 
- Informasjonsplanet innebærer at ledere søker utøve intern styring ved kommunikasjon og informasjonsutveksling. Slik søker de å influere andres forståelse og dermed implisitt for handling. I forhold til aktører i omgivelsene handler det om å innhente og forstå eksterne signaler. Slike signaler blir fortolket, oversatt og tilrettelagt for å deles med organisasjonen som grunnlag for handling.

- Aktørplanet handler om mobilisering og inspirasjon til målrettet aktivitet. Internt i organisasjonen eller enheten kan det handle om å oppmuntre og utruste medarbeidere til å ivareta oppgaver både på et individuelt og et gruppeplan. Eksternt handler det om etablering av nettverk til aktører, der hensikten både er å representere egen organisasjon, men også å fange opp sentrale utfordringer og muligheter som kan ha betydning for organisasjonen.

- Handlingsplanet handler om at ledere selv involveres i konkrete oppgaver og utøvelse av innflytelse. Ledere ivaretar dels selv mange konkrete oppgaver, som f.eks. å forberede styresaker, lede konkrete prosjekter eller veilede medarbeidere. I forhold til et eksternt miljø kan dette sies å handle om å ivareta forhandlinger og inngå avtaler/ etablere enighet med viktige partnere.

Jeg vil argumentere for at det er nyttig å operere med et fjerde nivå av ledelsespraksis, som kan knyttes til identitet og verdier for den kirkelige virkeligheten. Mens Mintzberg selv kun nevner denne funksjonen, ligger den tett på det Carroll (1991) knytter til kirkelig ledelse, som også fremstår gjennom empiriske undersøkelser av norsk kirkelig ledelse (Askeland, 2015; Fiske, 2017; Myrvang, 2020). Dette fjerde nivået kan omtales som følger:

- Lederes viktige symbolfunksjon, både ved representasjon og gjennom å artikulere formål og identitet. En slik kjerneprofil omtales gjerne som institusjonell ledelse, og er spesielt tydelig for toppledere på øverste nivå i en organisasjon. Det er særlig her egenarten ved kirkelig ledelse blir synlig, relatert til identitet, formål og oppdrag. Dette skjer gjennom symbolske handlinger, gjennom policy-dokumenter og planer samt i den daglige samtale der virksomhetens grunnlag utmeisles. Samtidig handler det også om å 
etablere rammer for virksomheten og sørge for at ulike grupper trekker i samme retning med hensyn til mål og kirkelige tjenester.

Uten å definere ledelse eksakt, er det mulig å ringe inn begrepet basert på gjennomgående felles oppfatninger i faglitteraturen. Her det også lagt til som premiss at virksomheten forstås som demokratisk styrt, og at det kirkelige premiss om embete/råd skal videreføres:

- Styre/råd, som representativt valgt organ, ivaretar styringsmyndigheten på vegne av menighetens medlemmer i soknet i samvirke mellom folkevalgte og representant for prestetjenesten (tjenesten med ord og sakrament).

- Ledere innehar en posisjon med et tillagt mandat/kompetanse fra styre/råd, og ledelsesansvaret innebærer innflytelse rettet mot koordinert oppgaveløsning.

- Ledelse innebærer å videreføre rådets signaler gjennom arbeidsgivers styringsrett i balanse med å mobilisere til handling gjennom kommunikasjon, motivasjon og samhandling.

- Ledelse utøves ved å initiere prosesser som bidrar til retning, avklaring og forståelsesrammer ved å skape arenaer for interaksjon og informasjonsutveksling.

- Ledelse er sosial og relasjonell, med kommunikasjon som et kritisk medium, og avhenger av tillit og legitimitet for å lykkes.

- Institusjonell (verdibevisst) ledelse bidrar til styring og mobilisering til handling gjennom bevisst fokus på identitet, formål og virksomhetens grunnleggende verdier.

Virksomhetens organisatoriske form og særskilte oppgave/tjeneste vil, sammen med kontekst, legge føringer for krav til og utforming av lederrollen. Å lede kirkelig virksomhet innebærer å være rammet inn av en normativ læretradisjon som inngår i en løpende fortolkningsprosess. Dette krever tilrettelegging, kjennskap til offentlig lov- og regelverk, avtaler utviklet gjennom partssamarbeid og også til økonomiske og administrative rammebetingelser. Ulike typer spørsmål som kan springe ut av en slik innramming skal avklares i et demokratisk valgt styringsorgan, og 
lederen skal deretter ivareta dette overfor et bredt spekter av tjenester og medarbeidere.

I kirke og menighet har medarbeidere ulik bakgrunn og utdanning, tilpasset det brede ansvar som ivaretas. For enkelte deler av kirkens samfunnsoppdrag, for eksempel relatert til gravferd og gravplassdrift, vil mange ta hånd om praktiske oppgaver med basis i ulike kortere og lengre fagutdanninger. For andre stillinger og tjenester vil det kunne være krav i tjenesteordning om høy utdanning og spesialisert profesjonskunnskap. Lederjobben krever dermed et bredt spekter av kompetanse for å ivareta ledelse av kirkens mangfoldige oppgaver. Ledere i kirken vil måtte både koordinere og lede arbeid, samt skape rammer og arenaer for medarbeideres arbeid med utgangspunkt i de mål og planer som er vedtatt.

\section{Konklusjon}

Hvilken relevans og overføringsverdi har ledelsesteorier fra en generell til en kirkelig kontekst? Avklaring av dette spørsmålet blir viktig når generelle innsikter skal relateres til lokalmenigheten, som på mange måter skiller seg fra de felter der ledelsesteoriene er utviklet. De siste tiårene har det vært økende oppmerksomhet på ledelse og ledere. Denne trenden har vært markert, både innen næringsliv og offentlig forvaltning, og har fått sitt nedslag i en mangfoldig ledelseslitteratur og et bredt undervisningstilbud.

Kapitlet viser at ledelsesbegrepet ikke er entydig, og at ledelse som fag heller ikke er et samlet fagfelt. I mye av den moderne ledelsesteori ses ledere som individuelle og rasjonelle agenter. I tillegg er det en tendens til å fremstille ulike faglige dikotomier, som primært skal fremme ett spesifikt perspektiv. Jeg har argumentert for at disse bidragene langt på vei kun gir delperspektiver til å forstå lederes jobb og praksis. I tillegg synes litteraturen på feltet, samt forvaltningspolitikken kirken er innvevd i, gjennomgående å anta at organisatorisk handling er avhengig av klare mål, spesifiserte planer og målbare resultater. Kapitlet bidrar til å supplere denne trenden ved å fremme verdiforankring og verdibevissthet som en sentral dimensjon, som konstituerer institusjonelt lederskap. 
I kapitlet legger jeg også vekt på at utøvelse av ledelse er avhengig av den organisasjon den utøves i. Ledere oppnår betydning gjennom tale og handling, og har en av sine hovedfunksjoner gjennom å bidra til at det innad i organisasjonen etableres fellesoppfatninger både av egen organisasjon og dens oppgaver og misjon. Noen konkrete konsekvenser av dette er skissert som en innramming til en avsluttende diskusjon om dimensjonene i en helhetlig ledelsesforståelse. I tillegg til disse dimensjonene utøves ledelse på flere nivår, fra kommunikasjon, via samhandling og til egen operativ innsats. Samtidig rammes disse nivåene inn av en rammesettende og identitetsorientert praksis.

Ledere og ledelse må samtidig antas å ha betydning, særlig på et par viktige felter. De vil for det første i stor grad kunne prege samarbeidsklima og relasjoner i en organisasjon, og bidra til at det fremmes en kultur av åpenhet og målorientering. Samtidig har ledere en viktig funksjon når beslutninger tas og ressurser fordeles i organisasjoner, jf. Mintzberg (2009), og her vil lederes evne til fortolkning av situasjon og ut fra det konkretisere handlingsmål være viktig.

\section{Referanser}

Andersen, J. A. (2006). Leadership, personality and effectiveness. The Journal of Socio-Economics, 35(6), 1078-1091. https://doi.org/10.1016/j.socec.2005.11.066 Arnulf, J. K. (2012). Hva er ledelse. Universitetsforlaget.

Askeland, H. (1998). Ledere og lederroller: Om ledelse og lederroller i den lokale kirke. Tapir.

Askeland, H. (2000). Drivkrefter i formingen av kirkelig organisering. Tidsskrift for Kirke, Religion, Samfunn, 13(1), 51-61.

Askeland, H. (2003a). Lederskap - løsning eller symbol. I H. Askeland, F. Grimstad, M. H. Hougsnæs \& G. Lande (Red.), Ledelse i kirken (s. 43-61). Kirkens arbeidsgiverorganisasjon.

Askeland, H. (2003b). Lederskapets kirkelighet. I H. Askeland, F. Grimstad, M. H. Hougsnæs \& G. Lande (Red.), Ledelse i kirken (s. 111-125). Kirkens arbeidsgiverorganisasjon.

Askeland, H. (2013). Verdibasert ledelse - historiske linjer og aktuelle perspektiver (Rapport 11/2013). Diakonhjemmet høgskole. VID Open. http://hdl.handle. net/11250/98639 
Askeland, H. (2015). Reforming the pastoral leadership structure in Church of Norway: Exploring whether and how the managerial role of the dean has been strengthened. I H. Askeland \& U. Schmidt (Red.), Church reform and leadership of change. Pickwick Publications.

Askeland, H. (2016). Ledelse og lederes rolle i Den norske kirke: Lederrolleundersøkelsen 2016 i et tyveårsperspektiv. Tidsskrift for Praktisk Teologi, 33(2), 5-19. https://journals.mf.no/tpt/article/view/5197

Askeland, H. (2017). Historiske linjer i utviklingen av verdibasert ledelse. I E. Aadland \& H. Askeland (Red.), Verdibevisst ledelse (s. 50-76). Cappelen Damm Akademisk.

Askeland, H. \& Grimstad, F. (1996). Kirkelig ledelse: En ressursbok om ledelse i den lokale kirke. Kirkens arbeidsgiverorganisasjon.

Askeland, H. \& Hansson, P. (Red.). (2005). The second international conference on church leadership: Uppsala, Sweden, September 15-16, 2005. Uppsala University/ Diakonhjemmet University College: The Peter Fjellstedt Foundation.

Beckford, J. A. (1975). Religious organization: A trend report and bibliography. De Gruyter Mouton.

Brunsson, N. (2011). New public organizations: A revivalist movement. I T. Christensen \& P. Lægreid (Red.), The Ashgate research companion to new public management (kap. 5). Taylor \& Francis. https://doi.org/10.4324/97813156 13321

Cameron, K. S., Quinn, R. E., DeGraff, J. \& Thakor, A. V. (2006). Competing values leadership. Creating values in organizations. Edward Elgar Publishing.

Carroll, J. W. (1991). As one with authority. John Knox Press.

Døving, E. (2016). Fagfolk og generalister som ledere i profesjonelle organisasjoner. I E. Døving, B. Elstad \& A. E. Storvik (Red.), Profesjon og ledelse (s. 255-271). Fagbokforlaget.

Fiske, M. (2017). Det er en kirkelig leder jeg er. Hvordan og på hvilken måte har kirkevergens lederrolle i Den norske kirke utviklet seg gjennom de siste tjue årene? [Mastergradsoppgave, VID vitenskapelige høgskole]. VID Open. http://hdl. handle.net/11250/2452812

Fougner, J. (2019). Norsk arbeidsrett. Styringsrett, samarbeid og arbeidstakervern. Universitetsforlaget.

Frank, T. E. (2007). The discourse of leadership and the practice of administration. The Journal of Applied Christian Leadership, 2(1), 32-53.

Gardner, W. L., Lowe, K. B., Moss, T. W., Mahoney, K. T. \& Cogliser, C. C. (2010). Scholarly leadership of the study of leadership: A review of The Leadership Quarterly's second decade, 2000-2009. The Leadership Quarterly, 21(6), 922-958. https://doi.org/10.1016/j.leaqua.2010.10.003 
Grace, M. (2003, 6.-8. november). Origins of leadership: The etymology of leadership [Paperpresentasjon]. International Leadership Association Conference, Mexico. http://www.ila-net.org/Publications/Proceedings/2003/mgrace.pdf

Grimstad, F. \& Askeland, H. (1999). Den lokale kirkes styrmenn og -kvinner sitter de ved roret? I M. H. Hougsnæs (Red.), Kirken, lekfolket og presteskapet. Kirkeliv og kirkereformer i Den norske kirke ved årtusenskiftet (s. 40-58). Kirkens arbeidsgiverorganisasjon.

Hales, C. (1999). Why do managers do what they do? Reconciling evidence and theory in accounts of managerial work. British Journal of Management, 10(4), 335-35o. https://doi.org/10.1111/1467-8551.00143

Hansson, P. (2001). Svenska kyrkans organisationskultur. Verbum.

Hegstad, H. (2009). «Én kropp-mange lemmer»: Skisse til tjenesteteologi for Den norske kirke. Halvårsskrift for Praktisk Teologi, 26(2), 29-38.

Huse, M. (1998). Prosten. Ansvar, arbeidssituation og ledelse. Tapir.

Kirkerådet. (1987). Kirkens embete \& råd. Hvem skal bestemme hva - og hvorfor? Utredning fra en arbeidsgruppe oppnevnt av Kirkerådet. Den norske kirke.

Kirkerådet. (2001). Myndighetsrelasjoner i Den norske kirke. Den norske kirke.

Kotter, J. P. (2001). What leaders really do. Harvard Business School Publishing Corporation.

Lotsberg, D. Ø. (1995). Aktør - ledelse - struktur. LOS-senter.

Mintzberg, H. (1989). Mintzberg on management: Inside our strange world of organizations. Free Press.

Mintzberg, H. (2009). Managing. Berrett-Koehler.

Myrvang, R. E. L. (2020). Kirkeverge som lokal kirkestrateg [Mastergradsoppgave]. VID vitenskapelige høgskole.

Pfeffer, J. (1977). The ambiguity of leadership. Academy of Management Review, 2(1), 104-112. https://doi.org/10.5465/amr.1977.4409175

Rost, J. C. (1998). Leadership and management. I G. R. Hickman (Red.), Leading organizations: Perspectives for a new era (s. 97-114). Sage.

Selznick, P. (1957). Leadership in administration: A sociological interpretation. Row Peterson.

Sirris, S. (2014). Pastoral ledelse i praksis. En empirisk undersøkelse av forholdet mellom soknepresters utøvelse av ledelse og forståelse av egne lederroller [Mastergradsoppgave]. VID vitenskapelige høgskole. VID Open. http://hdl. handle.net/11250/98523

Strand, T. (2007). Ledelse, organisasjon og kultur (2. utg.). Fagbokforlaget.

Tengblad, S. (2012). The work of managers: Towards a practice theory of management. Oxford University Press.

Yukl, G. (2010). Leadership in organizations. Prentice Hall. 



\title{
Lederskapets kirkelighet. En integrert modell for verdibevisst kirkelig ledelse
}

\author{
Harald Askeland \\ VID vitenskapelige høgskole
}

\begin{abstract}
The chapter argues that in order to develop an understanding of the specific nature of church management and leadership, there is a need for reconceptualizing the relationship of these terms. Through an elaboration of research on managerial work and institutional leadership work, and empirically grounded research on the mundane work of leaders, the chapter describes an integrated model of church management and leadership. The model bridges and integrates functional managerial leadership role models and institutional leadership. What distinguishes a church management and leadership model, compared to general models, lies partly in a relational instead of a competitive relation to community as context and partly in the values and faith it conveys. Thus, one important managerial leadership role is that of mediator between organization and community context; another is the role of institutional leadership relating to purpose, values and identity.
\end{abstract}

Keywords: church, institutional, leadership, model, practice

\section{Innledning}

Ledelse og lederskap er sentrale begreper for å forstå lederes jobb. Faget ledelse, både empiriske og mer normative bidrag, har gitt verdifulle innsikter i ledelse som fenomen og praksis. Samtidig er fagfeltet preget av ulike tilnærminger, noe som fordrer bevisste valg av perspektiv når vi skal belyse ledelse i kirken. Min vurdering er at dominerende teorier som har

Sitering av denne artikkelen: Askeland, H. (2021). Lederskapets kirkelighet. En integrert modell for verdibevisst kirkelig ledelse. I S. Sirris \& H. Askeland (Red.), Kirkelig organisering og ledelse: Et verdibasert og praksisorientert perspektiv (Kap. 8, s. 179-199). Cappelen Damm Akademisk. https://doi.org/10.23865/ noasp.129.ch8

Lisens: CC BY-NC-ND 4.0 
fått bred utbredelse, også innen kirkelig ledelsestilnærming, ofte bygger på et individualistisk og rasjonalistisk grunnlag, samt at de på unødvendig vis splitter forståelsen av ledelse ved å skille mellom «ledelse» (management) og «lederskap» (leadership) (Frank, 2006; Tengblad, 2012a).

Kapitlets tittel angir formålet: $\AA$ argumentere for at vi trenger å forstå sammenhengen mellom ledelse og lederskap, samt å presentere en modell som holder disse perspektivene sammen. Sammenhengen mellom «ledelse» og «lederskap» har vært omfattende bearbeidet, mens jeg i dette kapitlet presenterer det faglige og empiriske grunnlaget for å konseptualisere en integrert modell der begrepet «institusjonell ledelse» blir et nøkkelbegrep² (Askeland, 2016a, 2016b).

Behovet for å utvikle en integrert modell springer ut av to viktige forhold: For det første henger det sammen med en uforholdsmessig vekt på ledelse som et individualistisk og rasjonelt prosjekt, der organisatorisk effektivitet og måloppnåelse blir vurderingskriteriet for god ledelse. Dermed underkommuniseres betydningen av organisatorisk og kontekstuell forankring (Mintzberg, 2009), samt at ledelse i tillegg til å realisere mål også skal tilveiebringe mening i dialog med andre aktører (Eriksen, 1999; Smircich \& Morgan, 1982). Dette har, for det andre, ført til at ledelsesforskningen i stor grad har bygget på forskerutviklede hypoteser om hva ledelse er, der kvantitative spørreundersøkelser representerer majoriteten av studier. Den komplekse praksis som utfolder seg i organisasjoner til daglig og som ledere står midt oppe i og må håndtere, blir lite reflektert i forskningen.

I dette kapitlet trekker jeg veksler på alternative teoretiske begreper og metodisk tilnærmingsmåte. ${ }^{3}$ Kapitlet vil vektlegge de oppgaver og roller ledere ivaretar og utfolder i praksis, samt at dette skjer innen rammen av virksomheten med en organisatorisk forankring. Derfor vil jeg rette søkelyset mot ledelse i praksis, og tar utgangspunkt i en tilnærmingsmåte

2 Deler av kapitlet bygger på min avhandling, Hverdagsledelse: Diakoni, verdier og ledelse i praksis (Askeland, 2016a).

3 Siden 2004 har jeg ledet LIP-prosjektet (Ledelse og lederroller i praksis), dels som veileder for 20 mastergradsoppgaver og dels i egen forskning ved Diakonhjemmet høgskole/VID, med samme teoretiske fundament og med følge-observasjon som metode. Samlet sett har denne forskningen generert data fra ca. 80 lederes hverdager, og innsikter fra prosjektet danner et viktig norsk datagrunnlag som supplerer den internasjonale litteraturen. 
som benevnes managerial work behavior (MWB), med vekt på å studere og forstå selve lederjobben. I over femti år har denne tradisjonen utviklet innsikt i ledelse som praksis gjennom observasjonsstudier av lederjobben i sin organisatoriske kontekst (Korica et al., 2015). Særlig vil jeg argumentere for at modellutvikling med relevans for utøvelse av lederrollen $\mathrm{i}$ praksis kan knyttes til oppgaver og rolleprofiler ved å se hvordan ledere ivaretar sentrale funksjoner, oppgaver og prosesser. De mer tradisjonelle lederrolleprofilene vil bli supplert med en rolleprofil som ses som kjernen i lederskap. En slik kjerne er lederes bidrag til identitet og verdier i organisasjoner (Barnard, 1938). Når jeg finner å kunne videreføre og sammenstille disse tradisjonene, med en vektlegging av institusjonelt lederskap, er det fordi sosiologen Philip Selznick i sitt essay om den institusjonelle leder vektlegger at denne type ledelse må forstås og omtales som work (Selznick, 1957, s. 22).

Kapitlets tilnærming er først og fremst å sammenfatte empirisk funderte beskrivelser av hvordan ledelses- og lederskapspraksis foregår gjennom et sett av integrerte roller som ledere ivaretar i og for organisasjonen med en teoretisk modellutvikling. I tillegg bidrar kapitlet til en nødvendig begreps- og modellbygging på tvers av ulike tradisjoner. Til sist vil det etablere en teoretisk kobling mellom den konkrete organisatoriske kontekst, ledelse og lederskap (Hales, 1986).

\section{Konseptualisering av ledelse, institusjonelt lederskap og kontekst}

Den omfattende innsats som har skjedd innen ledelsesforskningen har ikke ledet til en omforent definisjon eller avklaring på spørsmålet om hva ledelse er og hvordan det utøves (Alvesson \& Kärreman, 2003, s. 36; Kirkhaug, 2015). Mye innsats er gjort for å utvikle teorier om ledelse som fenomen og hva god eller effektiv ledelse er (Andersen, 2006). Mindre oppmerksomhet er blitt gitt til den grunnleggende oppgave med a beskrive og analysere lederes jobb i relasjon til deres funksjon i og for organisasjonen de leder. Dette argumentet er blant annet formulert av ledelsesforskeren Henry Mintzberg: «In particular, we remain grossly ignorant about the fundamental content of the manager's job and 
have barely addressed the major issues and dilemmas in its practice» (Mintzberg, 1990, s. 8).

Tross dette hovedbildet, eksisterer det bidrag som søker å reformulere og konseptualisere ledelse basert på empiriske studier av lederes praksis (Arman et al., 2009; Askeland, 2015a; Karp, 2019; Sirris, 2019; Tengblad, 2012b; Vie, 2009), samt til å tematisere sammenhengen mellom begrepene ledelse og institusjonelt lederskap (Beaton, 2017; Raffaelli \& Glynn, 2015). Samtidig er det rom for tydeligere artikulering av den kontekstuelle siden av ledelse og lederskap i praksis (Askeland, 2016a; Barley \& Kunda, 2001; Johns, 2006). Kirke og menighet er preget både av den historiske kontekst og av en eksisterende institusjonell pluralisme, der ulike krav og forventninger brynes mot hverandre og må håndteres i daglig prioritering (Askeland et al., 2020). I den følgende seksjonen presenterer og drøfter jeg de teoretiske bidrag som bidrar til å etablere en kobling mellom begreper som, mot kapitlets avslutning, muliggjør konseptualiseringen av en integrert modell.

\section{Sammenhengen mellom ledelse og institusjonelt lederskap}

Innen den tradisjonen som forsker på lederes jobb, managerial work behavior (MWB), har en søkt å unngå normative definisjoner av ledelsesbegrepet. I stedet har utgangspunktet vært empiriske undersøkelser av hva lederjobben innebærer (Mintzberg, 1994; Stewart, 1989), noe som i hovedsak har gitt beskrivende analyser av ledelse som praksis. Likevel kommer man ikke utenom en underliggende forståelse av hva ledelse er (Hales, 1986) eller behovet for teoriutvikling innen denne tradisjonen (Martinko \& Gardner, 1985). Til tross for en hovedsakelig empirisk orientering, knytter denne forskningstradisjonen ledelse til sentrale kjennetegn: Det handler om ansvar for resultater (Hales, 1999), om å influere en gruppe (eller organisasjons) medarbeidere til kollektiv innsats for å realisere felles oppgaver eller mål med sikte på langsiktig overlevelse (Mintzberg, 2009), samt å fasilitere prosesser som muliggjør individuell og kollektiv mening og handling (Yukl, 2010) gjennom et bevisst arbeid med å vedlikeholde 
og utvikle de verdier som organisasjonen og dens formål bygger på (Selznick, 1957).

Mens det ofte synes fraværende innen generell ledelsesforskning, blir den organisatoriske forankring av mandat og ansvar som er det formelle grunnlaget for ledelse mer fremhevet innen MWB-tradisjonen (Hales, 1999). Ved å tydeliggjøre lederes mandat pekes det på at ledelse, i tillegg til å være en prosess som skjer i relasjon mellom ledere og medarbeidere, handler om å ivareta bestemte oppgaver eller funksjoner i og for organisasjonen (Vie, 2009, s. 7). Når studiet og forståelsen av ledelse har sitt utspring i hverdagspraksis, fremstår også konteksten som mer sentral. Samtidig kan kontekst forstås nokså snevert som de nært omkringliggende faktorer som eksterne aktører og bransje, og flere har derfor pekt på viktigheten av å utvide kontekstperspektivet til også å handle om hvordan ledelse forstås, formes og utøves innen institusjonelle rammer som definerer spillets regler (Noordegraaf \& Stewart, 2000). Ledere er gitt et ansvar og mandat med en formell autoritet og status i organisasjonen som danner grunnlaget for lederes mellommenneskelige og organisatoriske roller. De funksjoner og oppgaver som hittil er omtalt, forstått som organisatorisk ledelse, er i den internasjonale litteraturen dekket av begrepet management (Raffaelli \& Glynn, 2015; Selznick, 1957).

Når det kommer til begrepet lederskap, vil en hovedtradisjon knytte leadership til den personlige relasjon og lederes evne til å mobilisere gjennom visjoner og personlig karisma (Bryman, 1992). Kjernen i denne tilnærmingen er å forstå ledelse som en innflytelsesprosess uten eksplisitt å relatere til organisatorisk mandat, mellom leder og medarbeider, for å realisere felles formå (Burns, 1978; Rost, 1998). ${ }^{4}$ For dette kapitlets formål er det mer naturlig å knytte an til Selznicks begrep institusjonelt lederskap. Hans bidrag har i stor grad preget forståelsen av begrepet institusjonelt lederskap, gjennom hovedtesen: Lederen for et foretak blir statsmann idet han går over fra administrativ ledelse av et foretak til institusjonelt lederskap (Selznick, 1997/1957, s. 18), og innebærer særlig å «infusere»

4 Med utgangspunkt i Burns' arbeid, med mye samme premisser som Rost, er det opprinnelige begrepet om transformerende ledelse utviklet til transformasjonsledelse og autentisk ledelse (Avolio \& Bass, 1995; Walumbwa et al., 2008). 
verdier i organisasjonen ut over det som er teknisk påkrevd.5 Særlig er det hans klare forankring av ledelse som et organisatorisk mandat som gjør begrepet egnet til å bygge bro til lederjobbtilnærmingen i ledelsesforskning.

Bak dette synspunktet ligger et argument som knytter begrepet organisasjon til et saklig system av bevisst samordnet virksomhet. ${ }^{6}$ Mens organisasjoner ses som et instrument utformet for å gjøre en jobb, ses institusjoner som et naturlig produkt av sosiale behov og påtrykk samt med en særegen utviklet identitet. Her artikuleres et grunnleggende forskjellig syn på organisasjoner, som henholdsvis enten rasjonelt og analytisk eller fortolkende (Askeland, 2013). Selznick vektla at organisasjoner ikke var rent instrumentelle systemer, men sosiale systemer som bestod av individer og utgjorde et levende sosialt miljø som måtte ivaretas (1997/1957, s. 20). Institusjonalisering omtales som noe som fremkommer gjennom prosesser, avhengig av at organisasjonen over tid utvikler en særegen historie, gjerne knyttet til særlige situasjoner eller beslutninger som bidro til å definere organisasjonens karakter. Denne prosessen vil også henge tett sammen med virksomhetens innramming i og tilpasning til endring i de institusjonelle omgivelsene. Ikke minst har innslaget $\mathrm{i}$ sentrale stillinger for eksempel blitt påvirket av en samfunnsmessig endring i synet på likestilling og på menns og kvinners posisjon i arbeidsmarkedet. En grunnleggende svikt i lederskap inntrer, etter Selznicks syn, når arbeidet med å tydeliggjøre institusjonens formål - den bærende grunn for dens eksistens - blir forsømt:

Vi vil hevde at det er en av hovedoppgavene for lederskap å skape spesielle verdier og en bestemt sakkunnskap i organisasjoner. I denne forstand blir lederen en forkjemper for institusjonaliseringen ved å styre en prosess som ellers ville foregått mer tilfeldig og lettere hadde vært underlagt omstendighetene og historiens spill. [...] Den institusjonelle lederen er derimot i første rekke en ekspert i å fremme og bevare verdier. (Selznick, 1997/1957, s. 32f)

5 Valget begrunnes i at Selznick på en fruktbar måte er anvendt til å forstå det særegne ved kirkelig lederskap, både innen en teologisk tilnærming (Carroll, 1991) men også i norske empiriske studier (Fiske, 2017; Mjånes, 2017).

6 Se kapittel 4 (Askeland) i denne boken for diskusjonen om instrumentelle versus institusjonelle teorier om organisasjoner. 
Selznick vektlegger at organisasjoners grunnleggende hensikt, gjennom tydeliggjøring av formål, identitet og grunnleggende verdier, henger sammen med og bidrar til meningsskaping. Slik kan verdi- og identitetsarbeid prege holdninger og sedvaner. Dermed kan organisasjoner oppnå en sosial integrasjon som antas å overgå kapasiteten til formell samordning og en tradisjonell kommandostruktur. Lederes betydning ligger i at de er i posisjon til å influere policy gjennom avgjørende beslutninger og har potensiale for å prege organisasjonens langsiktige utvikling. Slike avgjørende beslutninger inkluderer rekruttering og opplæring av personale, etablering av systemer for hvordan ulike interesser i en organisasjon avveies i forhold til hverandre og gjennom samarbeid med andre organisasjoner. Selznicks grunnleggende lederskapsfunksjoner er reformulert for kirkelig lederskap av Carroll (2011, s. 98): «defining the organization's mission and role, embodying that purpose in its organizational life, and helping the organization and its members give expression to their distinctive values in the face of threats from without and within.»

Selznick legger til grunn at det kan gjøres et analytisk eller teoretisk skille mellom administratoren og lederen, men at disse funksjonene $\mathrm{i}$ daglig arbeid og praksis griper inn i hverandre. Denne måten å tilrettelegge relasjonen mellom begreper, som analytisk atskilt men sammenvevet i praksis, synes fruktbar, og er igjen blitt gjenstand for interesse (Kraatz, 2009; Raffaelli \& Glynn, 2015; Washington et al., 2008). Dette resonnementet, som vil utdypes noe i neste seksjon, utfordrer tradisjonelle posisjoner i faget. Der har man enten fastholdt ledelse som det sentrale begrep i relieff til styring (Ladegård \& Vabo, 2010) eller, noe som er mer vanlig, å skille mellom ledelse og lederskap gjennom begrepene «management versus leadership» (Kotter, 2001; Yukl et al., 2002).

Ut fra eksisterende bidrag er det mulig å presentere et analytisk skille mellom organisatorisk ledelse og institusjonelt lederskap (jf. figur 1). Her er det viktig å understreke at skillet er analytisk, mens det i praksis vil være vanskelig å skille fullstendig. Senere i kapitlet utdypes de enkelte observerte oppgavestrukturer som inngår i modellen, samt at jeg argumenterer for nytten av begge begreper gjennom en anvendelse som både skiller og holder dem sammen. Modellen er basert på analyser av observert praksis fortolket i lys av intervjuer. Ulike klynger av praksiser 
konstituerer ulike rolleprofiler ledere ivaretar, som inngår i og holdes sammen av en meta-rolle som konstituerer elementer i institusjonelt lederskap (Askeland, 2015a, 2015b).

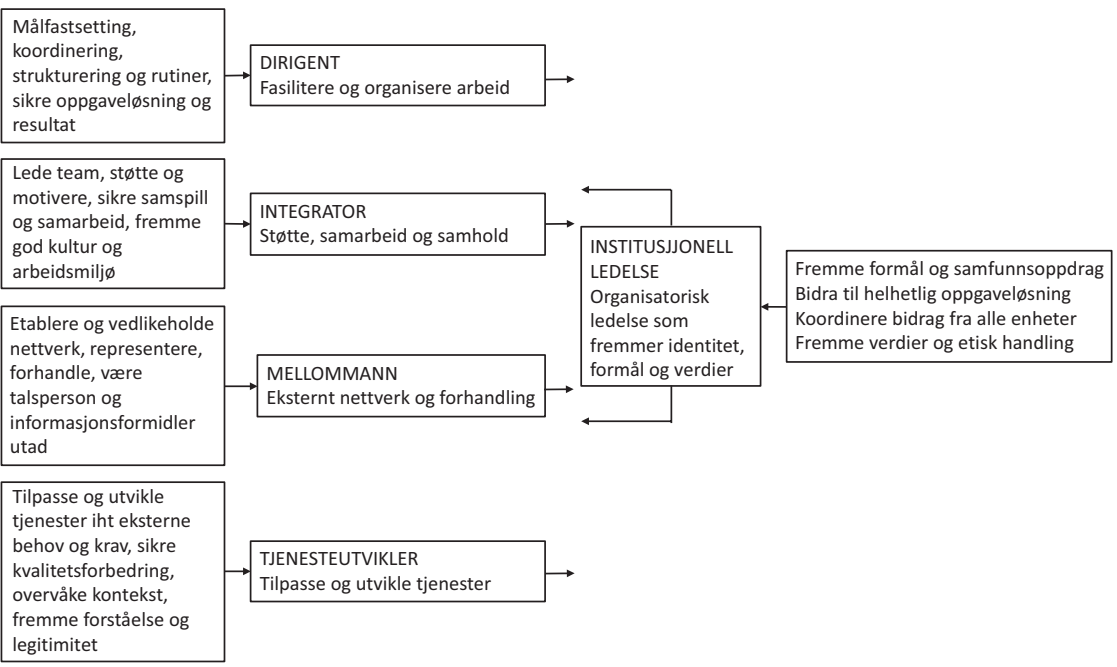

Figur 1. Integrasjon av lederrolleprofiler og institusjonell ledelse (basert på Askeland, 2016a)

Et siste viktig element er kontekst. I mange bidrag er kontekst nærmest forstått som de konkrete omgivelser en organisasjon opererer i, eller der ledelse utøves. Den amerikanske ledelsesforskeren Gary Johns (2006) argumenterer for betydningen av å forstå den foreliggende kontekst, da den er en viktig innramming for å fortolke hvordan aktører handler i situasjoner. Særlig blir dette viktig når en forstår ledelse-i-praksis som forankret i konkrete organisasjoner og situasjoner. En viktig side er at organisasjoner og deres institusjonaliserte omgivelser utgjør konteksten ledere må forholde seg til. Dessuten er det hevdet at ledere bidrar til å fortolke og skape organisasjonens realiteter, gjennom videreformidling internt av fortolkning og narrativer. Dermed bidrar de til å skape meningskonteksten for andres arbeid. Ghoshal \& Bartlett (1994, s. 92) argumenter med at ledere bidrar til å skape felles forståelse av organisasjonens formål:

[Leaders] can similarly create and embed in its context a work ethic that would induce rational yet value-oriented actions on the part of its members in furthering the interests of the organization as an end in itself, not just a means to an end. [...] It was created through tangible and concrete management actions. 
Dette innebærer også at forståelsen av ledelse bør tematisere hvordan ledere som aktører handler intensjonelt samtidig som de håndterer føringer innrammet av en etablert institusjonell orden. Kontekst kan ikke kun ses som en virkelighet utenfor aktøren, men må tilskrives et subjektivt element gjennom aktørens egen tolkning av den (Askeland, 1998). Dermed kan kontekst forstås med en tydelig kobling til mening, gjennom fortolkningen av situasjonsspesifikke forhold som vi velger eller kommer til å se som relevante (Scharfstein, 1991). Den relevante konteksten for kirke og menigheter vil være preget av institusjonell pluralisme, noe som innebærer en situasjon der organisasjoner møter og er innrammet av ulike institusjonelle sfærer (Struminska-Kutra \& Askeland, 2020). Religion, politikk og arbeidsliv kan for eksempel konstituere viktige sfærer som rammer inn kirkelig virksomhet. Dette leder til å vektlegge organisasjonens kjernevirksomhet, organisasjonens historie og tradisjon, ledernivå, sektor samt innramming i nasjonale reguleringer og reformer av betydning for organisasjonen.

\section{Integrert modell for kirkelig ledelse og lederskap}

Ulike bidrag har søkt å utvikle et integrert sett av lederroller eller rolleprofiler, enten ut fra deduktive tilnærminger eller basert på induktive analyser av ledelsespraksis. Eksempler på en tilnærming som søker å fange inn ulike funksjonelle lederdimensjoner, kan være den amerikanske ledelsesforskeren Robert Quinns (1984) modell av konkurrerende verdier og Torodd Strands (2007) anvendelse av modellen i en norsk kontekst (jf. også presentasjon av modellen i kapittel 9, s. 204). Modellen deler lederes sentrale funksjoner inn i fire sentrale lederroller: produsent, administrator, entreprenør og integrator. Denne firedelingen fremkommer ved å anvende to sentrale dimensjoner. Den første dimensjon vedrører enten

7 Robert Quinn har over tid utviklet og justert benevnelse på de ulike rollemodeller, i publikasjoner med andre forskere (Hart \& Quinn, 1993; Cameron et al., 2006). Imidlertid ligger modellens hoveddimensjoner og den sentrale kjernen i rolleprofilene fast. 
et internt og aktørorientert eller et eksternt og organisasjonsorientert fokus. Den andre er knyttet til enten en interesse for stabilitet og kontroll, eller en interesse for fleksibilitet og endring (Quinn \& Rohrbaugh, 1983, s. 367). Disse dimensjonene har vært tolket som sett med konkurrerende verdier eller orienteringer, som representerer anerkjente dilemmaer i organisasjoner. En induktiv analyse anvender også intern versus ekstern, men peker i tillegg på at ledere arbeider på ulike nivåer: Indirekte gjennom kommunikasjon, mer direkte i relasjon med medarbeidere og operativt gjennom egen involvering i organisatoriske aktiviteter og prosjekter (Mintzberg, 2009). Slik får modellen og aktuelle rolleprofiler mer kompleksitet, men med mange av de samme trekk.

En viktig side ved offentlige, kirkelige og ideelle organisasjoner som disse modellene ikke fanger opp i tilstrekkelig grad, kan for det første knyttes til deres basis i en ideologisk eller trosmessig tradisjon og verdiorientering. Både Mintzberg og Quinn viser til Selznicks vektlegging av verdiutvikling som lederoppgave, men henfører og tillegger det langt på vei til enkeltroller. Mens det for Hart og Quinn (1993) inngår i rollene som visjonæer og motivator (Hart \& Quinn, 1993), inngår dette aspektet hos Mintzberg (2009) i rollen som leder internt på det relasjonelle nivå. Min vurdering er at en integrert modell av ledelse bør søke å tydeliggjøre rollen som institusjonell leder som en sentral kjernerolle i modellen, slik både organisasjonsteoretikeren Chester Barnard (1938) og Selznick (1957) argumenterte for. Samtidig må andre organisatoriske særtrekk utmyntes, som innramming av lederjobben. Slike særtrekk er at kirken baseres på tradisjon og religiøse verdier, at den har en lang tradisjon der religiøse funksjonærer (eksempelvis prester, diakoner og biskoper) har hatt betydelig innflytelse og samtidig i moderne tid har utviklet et tydelig demokratisk fundament som grunnlag for organisering og styring (jf. neste seksjon).

En annen side ved denne type organisasjoner er deres samfunnsforankring og samfunnsoppdrag. Kombinasjonen av to andre dimensjoner - intern versus ekstern og oppgave versus relasjon - har de siste årene vært anvendt i bidrag med relevans for kapitlets formål. Bidragene omhandler lokalsamfunnsbaserte organisasjoner innen sivilsamfunnet (Schmid, 2010), diakonale institusjoner i Norge (Askeland, 2015a), samt 
av diakoners, prosters og kirkevergers lederroller i Den norske kirkes menigheter (Angell, 2014; Fiske, 2017; Mjånes, 2017). Jeg legger til grunn at tidligere modeller ikke har fanget opp offentlige, ideelle og religiøst funderte organisasjoner i tilstrekkelig grad, da disse ikke bare møter krav om effektivitet, men også til legitimitet. Disse forventningene knytter seg særlig til den rolle organisasjonen har i forhold til samfunnskonteksten, både til medlemmer og samarbeidende interesser. Kirken og dens menigheter er fremdeles omtalt i Grunnloven som nasjonens folkekirke, er understøttet av staten og skal som sådan være landsdekkende og demokratisk. Et annet forhold ved denne type organisasjoner, kan knyttes til identitet og verdier (Skjørshammer, 2010). Spørsmålet om verdier og identitet har vært mindre undersøkt i tradisjonell ledelsesforskning, men har vært artikulert i klassiske ledelsesfaglige bidrag (Barnard, 1938; Selznick, 1957) og har blitt sterkere vektlagt de siste tiårene. Denne orienteringen mot verdier og kultur er også omtalt som «the management of meaning» (Smircich \& Morgan, 1982). Dermed fremstår helhet, mening og verdiforankring som den sentrale dimensjon ved lederskap.

Resonnementene foran er de teoretiske begrunnelser for den integrerte ledelsesmodellen (Askeland, 2015a, 2016a), som søker å integrere sentrale og funksjonelle ledelsesprofiler med en kjerneprofil av institusjonelt lederskap. Den empiriske bakgrunnen er hentet fra ulike studier. Tydeligst blir det empiriske grunnlaget utfoldet gjennom en studie av lederhverdager, der analyse av observasjonsmaterialet, intervjuene og de policy-dokumenter de produserte resulterte i fire grunnleggende og en overordnet rolleprofil (Askeland, 2015a). Ved å analysere lederes egne beskrivelser av innhold i lederjobben, fremkom oppgavestrukturer som i utgangspunktet gav fire funksjoner eller rolleprofiler for ledelse som ble integrert av en overordnet rolleprofil: a) tjenesteutvikling; b) personalrelaterte oppgaver; c) koordinering; d) representasjon; e) overordnet ansvar for å knytte funksjonene sammen i helhet og innrammet av formål. Tilsvarende funn ble avdekket ved å analysere prosters oppfatning av kjernen i lederrollen (Askeland, 2015b), samt i observasjons- og intervjustudier av kirkeverger (Fiske, 2017; Myrvang, 2020). Analysen av lederes oppfatning av sentrale lederoppgaver, kan empirisk sammenfattes på tvers av tidligere bidrag i tabell 1. 
Tabell 1. Konseptualisering av lederrolleprofiler, basert på analyse av intervjumateriale (Askeland, 2015a, 2015b)

\begin{tabular}{|c|c|c|c|}
\hline \multicolumn{4}{|c|}{ Overordnet lederprofil (institusjonell leder) } \\
\hline \multicolumn{4}{|c|}{ Overordnet ansvar for hele organisasjonens resultater og fungering } \\
\hline \multicolumn{4}{|c|}{ Adressere grunnleggende verdier, formål og det kirkelige oppdrag } \\
\hline \multicolumn{4}{|c|}{ Overvåke omgivelser og formidle informasjon og ressursbehov mot omgivelser } \\
\hline \multicolumn{4}{|c|}{ Representere organisasjonen utad } \\
\hline \multicolumn{4}{|c|}{ Profilere og etablere nettverk mot partnere, tilskuddsytere og øvrige nivåer i kirken } \\
\hline \multicolumn{4}{|c|}{ Funksjonelle rolleprofiler } \\
\hline Utvikle tjenester & Personell & Koordinering & Representere \\
\hline Sikre tjenesteinnhold & Håndtere konflikt & Planlegge arbeid & Representant \\
\hline Tilpasse til endring & Sikre kompetanse & Influere & Møte interessenter \\
\hline Medlemskontakt & Utvikle ledere & Fordele ressurser & Forhandle kontrakter \\
\hline Strategi og planer & HMS-arbeid & Økonomikontroll & $\begin{array}{l}\text { Kontakt med } \\
\text { eksterne partnere }\end{array}$ \\
\hline Veilede & Være modell & Rapportering & Nettverksarbeid \\
\hline
\end{tabular}

De rolleprofiler som fremkommer integreres i en modell og fremstilles i figur 2, både med hensyn til hovedinnholdet i profilen og antatt viktige kontekstuelle dimensjoner.

Disse punktene peker i retning av viktige forhold som det er bred enighet om i litteraturen, og representerer et forsøk på å «definere» ledelse:

Ledelse er en organisatorisk forankret oppgave tilordnet rolle(r) med et særlig autorisert ansvar for å øve innflytelse og mobilisere til koordinert innsats for å realisere kirkens oppdrag, vedlikeholde identitet og nå felles mål og resultater. Dette arbeidet sikter særlig mot at organisasjonen både ivaretar sitt grunnleggende formål og at man sikrer en velfungerende virksomhet og overlevelse på sikt.

Den institusjonelle siden ved ledelse representerer viktige aspekter: For det første et overordnet ansvar for tjenesteutførelse og resultat i organisasjonen, som innebærer et ansvar for å holde ulike aktiviteter samlet i et fungerende hele. For det andre representerer dette også institutional leadership slik det er blitt beskrevet av Selznick (1957). Dette aspektet vektlegger ledelse forstått som meningsdanning og artikulering av formål, hvor en vil kunne fremme verdier generelt og institusjonens verditradisjon spesielt. Ledere bidrar dermed til å skape meningskontekst og en begrunnelse for virksomhetens formål. 


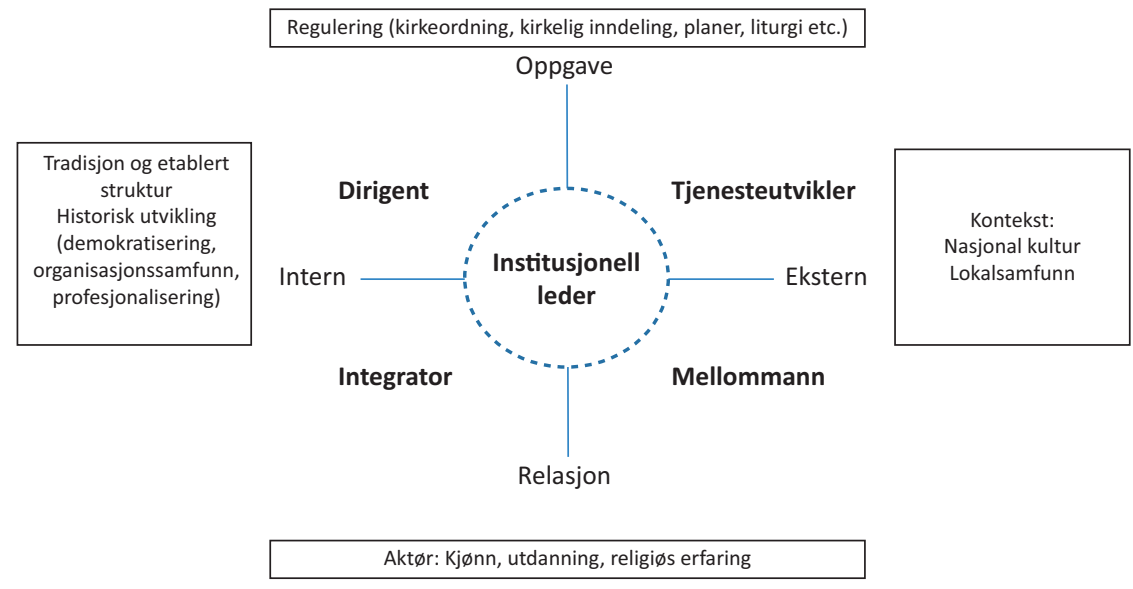

Figur 2. Integrert modell for ledelse og institusjonelt lederskap i praksis

Institusjonelt lederskap forstås ofte som tilbakeskuende, knyttet til vedlikehold av formål og identitet. Både Selznick sitt originale arbeid og nyere studier peker på at ledere kan ha en projektiv og strategisk intensjon i sitt arbeid (Askeland, 2020; Beaton, 2017; Struminska-Kutra \& Askeland, 2020). Denne type innsats kan blant annet handle om å arbeide frem nye strategier, verdier eller praksiser som både møter nye utfordringer og samtidig er forankret i tradisjonen. Slik mener jeg en dialogisk og prosessuell tilnærming kan fornye etablerte narrativer og knytte bånd mellom tradisjon og fornyelse.

Dirigenten kombinerer klassiske ledelsesoppgaver som det å utvikle og ivareta prosedyrer, initiere struktur og koordinere og planlegge arbeidsprosessen. Siktemålet med dette er å bidra til at virksomheten når sine mål på en effektiv og kvalitativt god måte. Denne rolleprofilen har et bredere sikte enn den administratorrollen som tradisjonelt er lagt til grunn. En viktig side ved rollekategorien er at hensyn til effektivitet og kvalitet er plassert som en intern og oppgaveorientert funksjon. ${ }^{8}$ Mye av grunnlaget for arbeidet ligger i eksterne (offentlige eller kirkelige) reguleringer

8 Både Quinn \& Rohrbaugh (1983) og Strand (2007) plasserer effektivitet eller produktivitet som en markedsorientert og ekstern funksjon. Begrunnelsen her er at offentlige og ideelle institusjoner, gjennom å utføre oppdrag på vegne av det offentlige, er pålagt intern kvalitetssikring, kontroll og effektiv ressursutnyttelse som del av selve oppdragsforståelsen. Det innebærer at det også gis et økt rom for å reflektere over effektivitet og produktivitet i lys av institusjonens diakonale agenda. 
og rapporteringskrav. Rolleprofilen ivaretar strukturelle aspekter gjennom å sikre at regler og systemer (personal, internkontroll, økonomi osv.) fungerer og etterleves i det daglige, og samtidig at virksomheten har klare mål med planer for styring av arbeidet. Mye av lederes møtevirksomhet dreier seg om realiseringen av denne funksjonelle profilen.

I rollen som tjenesteutvikler vektlegges en ekstern orientering. Rollen innebærer fokus på hvordan oppgaver blir utført, samt strategisk utvikling av mål og tjenester gjennom overvåking av og tilpasning til omgivelsene. Denne funksjonen representerer også en strategisk tilpasning som grunnlag for utvikling. I denne rollen forenes også et vertikalt aspekt ved at ledere og ledergruppers strategiforberedelser blir forankret i og endelig vedtas i styrende organer. Samtidig er for eksempel lokale kirkelige planer rammet inn av planer vedtatt av Kirkemøtet, og ofte tilpasset kommunale satsinger og behov. For å skape forståelse for virksomhetens behov og muligheter, vil ofte utviklingen ha en karakter av samskaping med lokale kommunal organer. Til denne rolleprofilen ligger det også å sørge for at det skapes en balanse mellom mulighet for utvikling og samtidig ofte en nødvendig tilpasning til skiftende ressursgrunnlag.

Integratorfunksjonen er intern og relasjonell i sin orientering, med vekt på sider ved lederjobben som bidrar til å binde organisasjonen sammen som et fungerende sosialt system. Ledelsesdimensjonen handler om at medarbeidere både arbeider slik at ulike elementer henger sammen, men også at enheten er integrert i og samhandler med andre enheter i virksomheten. Ledere bruker nær halvparten av sin tid i samhandling og samtale med egne medarbeidere, både gjennom faste og spontane møter og ikke minst gjennom korte, individuelle samtaler. Oppgaver som kan knyttes til denne funksjonen er å motivere medarbeidere, bidra til utvikling og utrustning, å konsultere og veilede i konkret oppgaveløsning samt å bidra til å utvikle team. I motsetning til internasjonale studier, som rapporterer at ledere stadig blir avbrutt av medarbeidere (Hales, 1999; Mintzberg, 2009; Tengblad, 2012b), viser norske studier at ledere ofte selv initierer samhandling og samtaler med medarbeidere (Askeland et al., 2015). De har videre mer preg av å være rådgivende og konsulterende enn av å være direkte instruerende. Den mer formidlende kommunikasjonen, som implisitt angir føringer for arbeid, skjer oftest i planlagte stabsmøter. 
Mellommannen er eksternt orientert med fokus på å bygge, vedlikeholde og videreutvikle eksterne relasjoner. Her er de instrumentelle og effektivitetsorienterte sider ved lederjobben nedtonet til fordel for det å søke legitimitet for virksomheten og dens behov i omgivelsene. Mens produksjons-, salgs- og tjenesteytingsvirksomheter kan sies å operere i et marked, er det mer nærliggende å forstå kirkens og menigheters arbeid som forankret i lokalsamfunn. Det samarbeides bredt mellom ulike sokn, med kommunale etater og med øvrige organisasjoner i lokalsamfunnet. Slik sett vil ledere både representere organisasjonen utad, samt at det konkrete arbeid både representerer et nettverksarbeid men også forhandlinger. Rollen innebærer et arbeid med å etablere allianser, men også å fungere som «buffer» ved eksternt press på organisasjonen. Lederjobben blir her sterkt farget av lokal kontekst, både med hensyn til antall enheter (f.eks. sokn), demografisk sammensetning i lokalsamfunnet samt ressursgrunnlag.

Lederes jobb og praksis preges også av generelle kontekstuelle faktorer. En viktig faktor er å søke å skape en kontinuitet mellom historisk gitte forutsetninger og tradisjon og nyere utfordringer som følger av institusjonell pluralisme. Særlig gjelder dette institusjonelt lederskap, men det legger også føringer for fornying av tjenester og koordinering av flere enheter. Kirken fremstår både som desentralisert, med selvstendige sokn i samhandling med lokalsamfunnet ved kommunen, og med en tydeligere sentralisert struktur ved en økende myndighet og voksende ansvar hos nasjonale organer. Hva de(n) enkelte aktører som ivaretar lederansvar bringer inn og får i oppdrag å vektlegge, må balanseres mot det trykk som eksisterende reguleringer angir.

Selv om beskrivelsen av de ulike roller i modellen er noe skissemessig, er hovedargumentet at modellen kan bidra til å forene ulike perspektiver og hensyn. Modellen kombinerer sentrale ledelsesdimensjoner som er valgt fordi de vurderes som relevante i forhold til den sektor diakonale institusjoner opererer i. Den søker dessuten å holde sammen sentrale funksjoner og oppgaveprofiler utledet av empiri, med ansvar for helhet og mening, slik Selznicks teori (1957) om institusjonell ledelse fremhevet.

Modellen vil til sist også kunne integrere et praksisperspektiv, som indikerer hvordan ulike aktiviteter eller funksjoner kan ivaretas på ulike 
nivåer. Hver enkelt profil vil ivareta mange forskjellige oppgaver, og dermed utøves på flere nivåer: På et informasjonsnivå vil ledere arbeide gjennom informasjon (tekst og tale) som grunnlag for å indikere retning, de vil samhandle på et aktørnivå med og påvirke andre på et relasjonsnivå og vil også til sist kunne operere selv gjennom konkrete aktiviteter og oppgaver på et handlingsnivå. Slik vil en kunne utforske modellen ytterligere, og vinne innsikt i hvordan de ulike funksjonelle profiler kan beskrives som praksis med fokus på informasjonsutveksling, samhandling og konkret operativ handling.

\section{Konklusjon og utblikk}

Kirkelig ledelse og institusjonelt lederskap i praksis i det daglige innebærer på mange måter å utøve en praksis som er nokså lik ledelse i andre organisasjoner. Mye tid går med til å håndtere driften av virksomheten, både gjennom møter og ikke minst i omfattende samhandling og samtale med egne medarbeidere. Samtidig blir saker med lengre perspektiv berørt, kanskje særlig i møter. Dette er her tolket som å ivareta generell ledelse. En særegen profil tematiserer mer langvarige prosjekter om identitet og verdier i praksis i konkret planlegging av senere aktivitet. Lederes arbeid med institusjonell identitet, formål og en agenda om verdifokus er særlig synlig ved å undersøke institusjonens plandokumenter og gjennom informantintervjuene der ledelsesfilosofi og intensjonalitet ved lederskap ble tematisert.

Modellen bygger på observasjon og intervjuer med ledere, samt på spørreundersøkelser der foreløpige profiler er operasjonalisert. Slik har den et empirisk fundament hentet fra ulike sektorer, men også spesifikt fra kirkelige og diakonale virksomheter. Den representerer en utvikling og endring av generelle ledelsesmodeller, ved å legge samfunnet til grunn som kontekst fremfor markedet. Konsekvensen av dette var å bytte ut produsentrollen med mellommannen. Samtidig er kirkelig virksomhet, i likhet med offentlig finansierte organisasjoner, pålagt konkrete mål og forventninger om god og effektiv ressursutnyttelse. Dette aspektet er derfor søkt fanget opp av dirigentrollen. Den kirkelige egenart er i tillegg søkt ivaretatt gjennom integrasjonen av institusjonell lederskapsprofil 
i en mer generell lederrollemodell. Med dette kan det oppnås to ting; både å understreke sammenhengen i praksis mellom operativ ledelse og utøvelse av institusjonelt lederskap, men også å skape en rolleprofil som vektlegger at kirkelig ledelse er forankret i kirkens oppdrag, formål og grunnleggende verdier.

\section{Referanser}

Alvesson, M. \& Kärreman, D. (2003). Att konstruera ledarskap. En studie av «Ledarskap» i praktiken. Nordiske Organisasjonsstudier, 5(2), 42-60.

Andersen, J. A. (2006). Leadership, personality and effectiveness. The Journal of Socio-Economics, 35(6), 1078-1091. https://doi.org/10.1016/j.socec.2005.11.066

Angell, O. H. (2014). Leiarar og leiarroller i Den norske kyrkja på lokalplan: Diakonen som leiar i ein norsk, luthersk tradisjon. Upublisert manus.

Arman, R., Dellve, L., Wikström, E. \& Törnström, L. (2009). What health care managers do: Applying Mintzberg's structured observation method. Journal of Nursing Management, 17(6). https://doi.org/10.1111/j.1365-2834.2009.01016.x

Askeland, H. (1998). Ledere og lederroller: Om ledelse og lederroller i den lokale kirke. Tapir forlag.

Askeland, H. (2013). Verdibasert ledelse - historiske linjer og aktuelle perspektiver (Rapport 11/2013). Diakonhjemmet høgskole. VID Open. http://hdl.handle.net/ $11250 / 98639$

Askeland, H. (2015a). Managerial practice in faith-based welfare organizations. Nordic Journal of Religion and Society, 28(1), 37-58.

Askeland, H. (2015b). Reforming the pastoral leadership structure in Church of Norway: Exploring whether and how the managerial role of the dean has been strengthened. I H. Askeland \& U. Schmidt (Red.), Church reform and leadership of change. Pickwick Publications.

Askeland, H. (2016a). Hverdagsledelse: Diakoni, verdier og ledelse i praksis [Doktorgradsavhandling, Det teologiske Menighetsfakultet]. VID Open. http://hdl.handle.net/11250/2501771

Askeland, H. (2016b). Ledelse og lederes rolle i Den norske kirke: Lederrolleundersøkelsen 2016 i et tyveårsperspektiv. Tidsskrift for Praktisk Teologi, 33(2), 5-19. https://journals.mf.no/tpt/article/view/5197

Askeland, H. (2020). Institutional leadership: Maintaining and developing the «good» organisation. I H. Askeland, G. Espedal, B. J. Løvaas \& S. Sirris (Red.), Understanding values work: Institutional perspectives in organizations and leadership (s. 139-158). Palgrave Macmillan. https://doi.org/10.1007/978-3-03037748-9 
Askeland, H., Blomander, C. \& Aasen, A. (2015). Jakten på ledelse i praksis. Nordiske Organisasjonsstudier, 17(1), 3-30.

Askeland, H., Espedal, G., Løvaas, B. J. \& Sirris, S. (2020). Understanding values work: Institutional perspectives in organizations and leadership. Palgrave Macmillan. https://doi.org/10.1007/978-3-030-37748-9

Avolio, B. J. \& Bass, B. M. (1995). Individual consideration viewed at multiple levels of analysis: A multi-level framework for examining the diffusion of transformational leadership. The Leadership Quarterly, 6(2), 199-218. https://doi.org/10.1016/ 1048-9843(95)90035-7

Barley, S. R. \& Kunda, G. (2001). Bringing work back in. Organization Science, 12(1), 76-95. https://doi.org/10.1287/orsc.12.1.76.10122

Barnard, C. (1938). The functions of the executive. Harvard University Press.

Beaton, E. E. (2017). Managerialism, mission, \& values: Micromechanisms of nonprofit institutionalization. University of Massachusetts.

Bryman, A. (1992). Charisma and leadership in organizations. Sage.

Burns, J. (1978). Leadership. Harper \& Row.

Cameron, K. S., Quinn, R. E., de Graff, J. \& Thakor A. T. (2006). Competing values leadership. Creating values in organizations. Edgard Elgar Publishing.

Carroll, J. (1991). As one with authority. John Knox Press.

Carroll, J. W. (2011). As one with authority: Reflective leadership in ministry. Wipf and Stock Publishers.

Eriksen, E. O. (1999). Kommunikativ ledelse: Om verdier og styring i offentlig sektor. Fagbokforlaget.

Fiske, M. (2017). Det er en kirkelig leder jeg er. Hvordan og på hvilken måte har kirkevergens lederrolle i Den norske kirke utviklet seg gjennom de siste tjue årene? [Mastergradsoppgave, VID vitenskapelige høgskole]. VID Open. http://hdl. handle.net/11250/2452812

Frank, T. E. (2006). Leadership and administration: An emerging field in practical theology. International Journal of Practical Theology, 10(1), 113-136. https://doi. org/10.1515/IJPT.2006.009

Ghoshal, S. \& Bartlett, C. A. (1994). Linking organizational context and managerial action: The dimensions of quality of management. Strategic Management Journal, 15(S2), 91-112. https://doi.org/10.1002/smj.4250151007

Hales, C. P. (1986). What do managers do? A critical review of the evidence. Journal of Management Studies, 23(1), 88-115. https://doi.org/10.1111/j.1467-6486.1986. tboog36.x

Hales, C. (1999). Why do managers do what they do? Reconciling evidence and theory in accounts of managerial work. British Journal of Management, 1o(4), 335-350. https://doi.org/10.1111/1467-8551.00143 
Hart, S. L. \& Quinn, R. E. (1993). Roles executives play: CEOs, behavioral complexity, and firm performance. Human Relations, 46(5), 543-574. https://doi. org/10.1177/001872679304600501

Johns, G. (2006). The essential impact of context on organizational behavior. Academy of Management Review, 31(2), 386-408. https://doi.org/10.5465/amr. 2006.20208687

Karp, T. (2019). God nok ledelse. Hva ledere gjør i praksis. Cappelen Damm Akademisk.

Kirkhaug, R. (2015). Lederskap. Person og funksjon. Universitetsforlaget.

Korica, M., Nicolini, D. \& Johnson, B. (2015). In search of «managerial work»: Past, present and future of an analytical category. International Journal of Management Reviews, 19(2), 151-174. https://doi.org/10.1111/ijmr.1209o

Kotter, J. P. (2001). What leaders really do. Harvard Business School Publishing Corporation.

Kraatz, M. S. (2009). Leadership as institutional work: A bridge to the other side. I T. B. Lawrence, R. Suddaby \& B. Leca (Red.), Institutional work: Actors and agency in institutional studies of organizations (s. 59-91). Cambridge University Press.

Ladegård, G. \& Vabo, S. I. (2010). Ledelse og styring. Fagbokforlaget.

Martinko, M. J. \& Gardner, W. L. (1985). Beyond structured observation: Methodological issues and new directions. Academy of Management Review, 10(4), 676-695. https://doi.org/10.5465/amr.1985.4279093

Mintzberg, H. (1990). The manager's job: Folklore and fact. Harvard Business Review. https://hbr.org/199o/o3/the-managers-job-folklore-and-fact

Mintzberg, H. (1994, 15. oktober). Rounding out the manager's job. MIT Sloan Management Review, 53(4). https://sloanreview.mit.edu/article/rounding-outthe-managers-job/

Mintzberg, H. (2009). Managing. Berrett-Koehler.

Mjånes, Å. S. (2017). Kvar er seg sjølv noerast. Eit kvantitativt studie av prostar og kyrkeverjer sine leiarroller og legitimitet i Den norske kyrkja [Mastergradsoppgave, VID vitenskapelige høgskole]. VID Open. http://hdl.handle.net/11250/2452752

Myrvang, R. E. L. (2020). Kirkeverge som lokal kirkestrateg [Mastergradsoppgave]. VID vitenskapelige høgskole.

Noordegraaf, M. \& Stewart, R. (2000). Managerial behaviour research in private and public sectors: distinctiveness, disputes and directions. Journal of Management Studies, 37(3), 427-443. https://doi.org/10.1111/1467-6486.00187

Quinn, R. E. (1984). Applying the competing values approach to leadership: Toward an integrative framework. I J. G: Hunt, D.-M. Hosking \& C. A. Schriesheim (Red.), Leaders and managers: International perspectives on managerial behavior and leadership (s. 10-27). Pergamon. 
Quinn, R. E. \& Rohrbaugh, J. (1983). A spatial model of effectiveness criteria: Towards a competing values approach to organizational analysis. Management Science, 29(3), 363-377. https://doi.org/10.1287/mnsc.29.3.363

Raffaelli, R. \& Glynn, A. (2015). What's so institutional about leadership? Leadership mechanisms of value infusion. I M. S. Kraatz (Red.), Institutions and ideals: Philip Selznick's legacy for organizational studies (s. 283-316). Emerald. https://doi. org/10.1108/So733-558X20150000044011

Rost, J. C. (1998). Leadership and management. I G. R. Hickman (Red.), Leading organizations: Perspectives for a new era (s. 97-114). Sage.

Scharfstein, B.-A. (1991). The dilemma of context. NYU Press.

Schmid, H. (2010). Organizational change in human service organizations. I Y. Hasenfeld (Red.), Human services as complex organizations (2. utg., s. 455-479). Sage Publications.

Selznick, P. (1957). Leadership in administration: A sociological interpretation. Row Peterson.

Selznick, P. (1997). Lederskap. Tano Aschehoug. (Opprinnelig utgitt 1957)

Sirris, S. (2019). Managers negotiating identities: Hybridizing professionalism and mangerialism in faith-based health organizations and in religious organizations [Doktorgradsavhandling, VID vitenskapelige høgskole]. VID Open. http://hdl. handle.net/11250/2632293

Skjørshammer, M. (2010). Kunsten å institusjonalisere barmhjertighet. Om bruk av organisasjonsmythos i verdibasert ledelse. I E. Aadland (Red.), Kan institusjoner elske? Samtidsessayer om diakonale virsomheter (s. 98-112). Akribe.

Smircich, L. \& Morgan, G. (1982). Leadership: The management of meaning. Journal of Applied Behavioural Studies, 18(3), 257-273. https://doi.org/10.1177/002188638 201800303

Stewart, R. (1989). Studies of managerial jobs and behaviour: The ways forward. Journal of Management Studies, 26(1), 1-10. https://doi.org/10.1111/j.1467-6486. 1989.tboo713.x

Strand, T. (2007). Ledelse, organisasjon og kultur (2. utg.). Fagbokforlaget.

Struminska-Kutra, M. \& Askeland, H. (2020). Foxes and lions: How institutional leaders keep organisational integrity and introduce Change. I H. Askeland, G. Espedal, B. J. Løvaas \& S. Sirris (Red.), Understanding values work: Institutional perspectives in organizations and leadership (s. 117-138). Palgrave Macmillan. https://doi.org/10.1007/978-3-030-37748-9

Tengblad, S. (2012a). Overcoming the rationalistic fallacy in management research. I S. Tengblad (Red.), The work of managers: Towards a practice theory of management (s. 3-17). Oxford University Press.

Tengblad, S. (2012b). The work of managers: Towards a practice theory of management. Oxford University Press. 
Vie, O. E. (2009). Shadowing managers engaged in care: Discovering the emotional nature of managerial work [Doktorgradsavhandling, Norges teknisknaturvitenskapelige universitet]. NTNU Open. http://hdl.handle.net/11250/265657

Walumbwa, F. O., Avolio, B. J., Gardner, W. L., Wernsing, T. S. \& Peterson, S. J. (2008). Authentic leadership: Development and validation of a theory-based measure. Journal of Management, 34(1), 89-126. https://doi.org/10.1177/0149206307308913

Washington, M., Boal, K. B. \& Davis, J. N. (2008). Institutional leadership: Past, present, and future. I R. Greenwood, R. Suddaby, C. Oliver \& K. Sahlin (Red.), Handbook of organization institutionalism (s. 721-736). Sage.

Yukl, G. (2010). Leadership in organizations. Prentice Hall.

Yukl, G., Gordon, A. \& Taber, T. (2002). A hierarchical taxonomy of leadership behavior: Integrating a half century of behavior research. Journal of Leadership \& Organizational Studies, 9(1), 15-32. https://doi.org/10.1177/107179190200900102 



\title{
KAPITTEL 9
}

\section{Roller, identitet og ledelse i praksis}

\author{
Stephen Sirris
}

VID vitenskapelige høgskole

\section{Harald Askeland}

VID vitenskapelige høgskole

\begin{abstract}
Roles denote external expectations towards a social position, while identity refers to self-understanding. This chapter links these concepts with a research tradition emphasising a practice approach to leadership. We provide empirical material from several studies, spanning twenty years, of leaders in the Church of Norway. We ask: What are the role patterns of different church leaders, and how have these role patterns developed? We find that ecclesial roles grow in terms of managerial content and organizational basis. Moreover, they are becoming more alike. Hybridization of roles and identities can lead to tensions between professional and managerial preferences, which is a promising avenue for future research.
\end{abstract}

Keywords: church, church wardens, hybridization, identity, pastors, role

\section{Introduksjon}

Ingen kommer som et ubeskrevet blad til en kirkelig stilling, og ingen begynner $\mathrm{i}$ en stilling som er fullstendig åpen. Hver leder bringer med seg sin egen unike kombinasjon av erfaringer og kompetanser. Ledere har prioriterte områder og en agenda for hva de vil. Samtidig preges lederstillinger av kontekstuelle forutsetninger og rammer. Stillinger opprettes og profileres for å realisere særskilte oppgaver og formål. Man setter egne aksenter på arbeidet og utformer jobben på sin særegne måte, ut fra forventninger og handlingsrom som lederrollen gir. 
Identitet og rolle er to sentrale begreper i studiet av lederes praksis. Identitet tar utgangspunkt i det «indre liv» og omhandler varige, sentrale og distinkte trekk ved individet. Identitet uttrykker selvforståelse og knyttes til personlighet og selvbilde. Hvem vi er, vises gjennom individuelle valg og handlinger, men også ut fra våre fellesskap. Rolle omhandler det «ytre liv». I en ny jobb møter man umiddelbart forventninger fra andre. Rolle er summen av normer og forventninger til en oppgave eller en sosial posisjon. I organisasjoner er lederjobben knyttet til posisjon og hviler på et formelt forankret mandat som posisjon, organisasjonskart og styringsrett (Mintzberg, 2009).

Dette kapitlet tar utgangspunktet $i$ at endring i kirkelig organisering, har konsekvenser for lederrollene. Endring i organisering samt styrings- og ledelsesstrukturer vil kunne medføre spenninger mellom ulike stillinger der etablert ansvarsdeling forandres. Endringene kan berøre en profesjons eller ledergruppes etablerte rolleforståelse, og individuelle lederroller. Endring vil også kunne utvide handlingsrommet mellom strukturelle forutsetninger og lederes agenda hvor identiteter kan omdannes. Kapitlet svarer på spørsmålet: Hva er ifølge empiriske lederundersøkelser sentrale rollemønstre for kirkelige ledere, og hvordan har rollemønstrene utviklet seg? Vi redegjør først for begrepene identitet og rolle, og for sammenhengen mellom dem og til ledelse i praksis. Deretter ser vi hvordan begrepene er utforsket empirisk i Den norske kirke gjennom flere utvalgte studier. Kapitlet bidrar dermed med en samlet oversikt over en sentral del av ledelsesforskningen i denne konteksten og drøfter likheter og forskjeller mellom studiene.

\section{Teoretiske perspektiver}

\section{Rolle}

En rolle består av summen av normer og forventninger som knytter seg til en posisjon eller stilling. Rollebegrepet forutsetter stabile samhandlingsrelasjoner som danner grunnlag for varige normer og forventninger til rolleatferd (Askeland, 1998, s. 34). Forventninger kan skjelnes i to typer (Sirris, 2013, s. 21): Konstituerende forventninger beskriver formelle 
forventninger som formelt innholdsbestemmer og identifiserer rollen. Ytre regelverk og institusjonelle rammer uttrykkes eksempelvis gjennom utlysningstekst, stillingsinstruks og tjenesteordning. Strategiske forventninger er derimot uformelle og kommer fra omgivelsene. Disse består av andre subjektive oppfatninger om hvordan en rolle bør ivaretas. Vanligvis opplever yrkesutøvere motstridende forventninger gjennom krysspress eller rollekonflikt.

Internaliserte meninger og forventninger assosieres med en rolle. En rolle er forankret i forventninger til en organisatorisk funksjon og knyttet til sosial posisjon (Stryker \& Burke, 200o, s. 289). Dette grunnleggende funksjonalistiske rollesynet har vært sentralt i internasjonale og norske kirkestudier i vektlegging av rolleinnehaverens selvstendige fortolkning og profilering av rollen (Askeland, 1998; Blizzard, 1956; Hansson \& Andersen, 2008; Hedin, 2009; Sirris, 2019). Ledelse utgår da både fra formelle beskrivelser av arbeidsoppgaver og ansvar, fra andres strategiske forventninger og fra lederes egne fortolkninger av mandat og rollens handlingsrom. Men rollebegrepet har også blitt kritisert som statisk (Järventie-Thesleff \& Tienari, 2016), og kan forstås som et spekter fra aktørers tolkning og improvisasjon til gitte og mer eller mindre faste skript. Vi forstår rolle som rammer for hvordan man skal fortolke seg selv og sitt arbeid. Skript er aktiviteter og mønstre i interaksjon typisk for bestemte settinger. Dette dynamiske rollebegrepet er hentet fra sosial interaksjonisme. Ledelsesforskerne Barbara Simpson og Brigid Carroll (2008, s. 43) forstår rolle som et verktøy som medierer og forhandler mening. Rolle er dermed et grenseobjekt som kan fylles med mening og formes. Rolle og identitet utvikler seg. Identitetsarbeid er å håndtere rollekrav og brukes for å utfordre og endre en rolle. De blir dermed to sider av samme sak. Vi vektlegger betydningen av å se hvordan rolleinnehavere arbeider for å komme til rette med flere roller.

Et sentralt spørsmål er om ledere har handlingsrom og frihet (aktørskap), eller om de er bundet av systemet og etablerte ordninger (struktur). Mange vil hevde at ledere har et situert aktørskap med handlingsrom som er begrenset, såkalt embedded agency (Battilana \& D’Aunno, 2009). Menigheten kan utgjøre en struktur eller et redskap som lederne, i egenskap av å være aktører, kan påvirke og utforme til egne og organisasjonens 
formål. I aktørskapet ligger prioriteringer, valg og ansvar. Vi legger til grunn at rolle knytter sammen struktur og aktør.

\section{Rolletypologier}

Det finnes ulike kategoriseringer av lederroller. Organisasjonsteoretikeren Torodd Strand (2001) har videreutviklet typologien til den amerikanske ledelsesforskeren Ichak Adizes (1980), som ble anvendt i tidlige kirkelige studier (Askeland, 1998). Modellen skiller mellom en intern og en ekstern orientering, og dernest hvorvidt oppgaver omhandler endring eller stabilitet. Rollene har bestemte oppgavetyper eller funksjoner. Ifølge Adizes (1980) ivaretas fire funksjoner gjennom en helhetlig lederrolle (Sirris, 2016, s. 82). Produsentrollen vektlegger oppgaveorientering, det å skape resultater og å nå mål. Administratorrollen preges av planlegging, regeldanning, koordinering og kontroll. Å få systemer til å fungere, er avgjørende for denne lederrollen. Derimot sikrer entreprenørrollen utvikling og innovasjon gjennom strategi for å oppdage nye handlingsmuligheter. Lederen iverksetter nye tiltak, er kreativ og løsningsorientert. Avslutningsvis får integratorrollen personer til å samarbeide i grupper. Denne kulturbyggende rollen vektlegger relasjoner og omsorg. Mens integratorer og produsenter primært er rettet mot interne forhold i organisasjonen, er de to andre rettet mot eksterne forhold. En leder kan ikke selv fylle alle rollene like godt, men rollesettet må samlet sett ivaretas i organisasjonen. Rolletypologier tar utgangspunkt i arbeidsoppgaver og ansvar, men kan også kartlegge forventninger man opplever å møte til egen rolle eller de man har til andres roller.

Adizes' rolletypologi (PAIE) ble senere videreutviklet i competing values framework (Cameron et al., 2014). Videreutviklingen av PAIEmodellen som anvendes senere i dette kapitlet (Askeland, 2016), tar utgangspunkt i en tradisjon som studerer ledelse som praksis. Denne tradisjonen omtales ofte som managerial work behavior (MWB) og utvikler begreper og teorier ut fra observasjon av lederes arbeidshverdag (Mintzberg, 2009; Stewart, 1989). Modellen bygger på to sentrale dimensjoner som går igjen i ulike teorier og studier: For det første anvendes en dimensjon som bygger på at ledere har både et fokus og ansvar for organisasjonens indre 
liv, og samtidig et fokus og ansvar for å overvåke, formidle til og tilbakeføre signaler fra den eksterne konteksten (Mintzberg, 2009; Quinn \& Rohrbaugh, 1983). For det andre anvendes en dimensjon som ut fra empiriske studier av lederjobben vektlegger henholdsvis oppgaver og strukturering på den ene side og relasjoner og hensyn til medarbeidere på den andre. Denne dimensjonen ligner stabilitet versus endring, da oppgaveorientering ofte tenderer mot standardisering og relasjonsorientering krever fleksibilitet. Mens den opprinnelige dimensjonen er utledet av teori, er dimensjonen oppgave-relasjon fremkommet gjennom observasjon og analyse av ledelsespraksis. Valget av aksen oppgave-relasjon gir etter vårt syn bedre mulighet for å erstatte produsentrollen med en rolle som reflekterer at kirke og menighet er organisasjoner som eksisterer og virker i lokalsamfunn (jf. også diskusjon i kapittel 8, s. 190-193). Der kan medlemmer og ulike grupper forstås som interessenter - fremfor konkurrenter - som de eksterne aktører organisasjonen forholder seg til (Angell, 2011; Schmid, 2010). Denne rolleprofilen omtales som mellommann. Rolleprofilene fremgår av tabell 1 (se også kapittel 8 om ledelse og institusjonelt lederskap).

Tabell 1. Rolleprofiler (basert på Adizes, 1980)

\begin{tabular}{lll}
\hline & Intern & Ekstern \\
\hline Oppgave (stabilitet) & Dirigent & Tjenesteutvikler \\
Relasjon (endring) & Integrator & Mellommann/Brobygger \\
\hline
\end{tabular}

\section{Identitet}

Som det foregående viser, henger rolle og identitet sammen på flere måter og deler samme begrepshistorie. Identitet refererer til mange og sammensatte meninger som en person knytter til seg selv og andre. Den forbinder ulike erfaringer og reduserer fragmentering i følelser og tanker. Identitet formes av flere faktorer som eksterne rolleforventninger, arbeidskontekst og situasjon, samt indre faktorer som personlighetstrekk, biografi og ledelsesidealer (McAdams \& McLean, 2013). Identitet er det man oppfatter som sentrale, distinkte og varige trekk (Albert \& Whetten, 1985) ved personer, grupper eller organisasjoner. De sentrale trekkene inkluderer verdier, praksiser og tjenester som er fundamentale for å forstå hva man 
individuelt eller kollektivt er og gjør. Varige trekk omhandler sammenhenger og kontinuitet, mens distinkte trekk innebærer sammenligning med andre. Identitet er altså både noe som skiller og differensierer fra andre, samtidig som det knytter til grupper man identifiserer seg med.

\section{Ulike identiteter}

Sosiale identiteter refererer til forståelse av seg selv som medlem av sosiale kategorier; for eksempel kjønn, nasjonalitet, søster eller kateket. Personlig identitet er knyttet til unike trekk ved personen. Rolleidentitet handler om hvordan er person identifiser med en gitt rolle - hvor betydningsfullt og omfattende er det for en person å være menighetspedagog eller fadder? Gjennom hverdagen går vi inn i en rekke roller avhengig av situasjon og hvem vi møter. I et konstruktivistisk perspektiv, er ikke identitet noe statisk og uforanderlig, men noe som utvikles og forhandles. Dette utviklingsarbeidet består i å utforske, utprøve og utvikle hvem man er, og kalles identitetsarbeid (Sveningsson \& Alvesson, 2003). Det skjer typisk når man opplever rolleoverganger, for eksempel når man begynner i ny jobb, eller når det skjer større endringer i livet. I slike overganger er rollemodeller viktige. Ved å iaktta andre personer i en lignende rolle, dannes en referanse. I praksisdelen av profesjonsutdannelser skjer nettopp dette. Studentene får en veileder og har en anledning til å prøve ut ulike varianter av en rolle for dernest å evaluere sine eksperimenter med egne interne standarder og eksterne tilbakemeldinger (Ibarra, 1999, s. 764). Man kan i varierende grad identifisere seg med rolleforventninger og utforske handlingsrommet gjennom improvisasjon. Identitetsforhandling er samspillet mellom selv-identitet, identitetsarbeid og identitetsregulering (Alvesson \& Willmott, 2002). Profesjonslogikk og styringslogikk gir altså maler eller oppskrifter for identitetsdanning. Eksempelvis gir arbeidsbeskrivelser et skript på hva man skal gjøre. Profesjonsidentitet er det profesjonelle selv basert på relativt stabile og varige sett av attributter, tro, verdier og erfaringer som påvirker hvordan individer ser dem selv i en profesjonell rolle (Ibarra, 1999). Jobbtittel er et identitetsmerke som representerer ansvar, kunnskap og kompetanse (Ashforth \& Kreiner, 1999).

Identitet, inkludert profesjonsidentitet og lederidentitet, er dermed kontinuerlig konstruksjon av selvet. Samtidig er identitet ikke helt 
flytende, men har også en fast kjerne som den britiske sosiologen Anthony Giddens (1991) kaller selv-identitet. Det betegner den organiserte og stabile fortellingen om en selv. Ofte brukes slike narrativer, hentet fra eget livsløp med særlige begivenheter og vendepunkter, for å forhandle mellom den ytre verden og det indre livet på en måte som tillater meningsdanning. Religion, diskurser og logikker er meningssystemer som individer kan trekke veksler på. For eksempel møter ansatte og ledere i kirken kristen tro som en ressurs som for svært mange inngår i identitetsdannelsen. Gjennom identifikasjon med kirken og troen, ser man sitt liv i lys av en større meningssammenheng. Identitet er altså situert, men ikke helt uten retning.

\section{Empiriske studier av roller og identitet i Den norske kirke}

\section{Ledelse i praksis}

Kapitlet har så langt presentert sentralt teorigrunnlag for forskningsprogrammet Ledelse i praksis (LIP). Dette forskningsprogrammet ved VID vitenskapelige høgskole startet i 2006. Sentrale spørsmålsstillinger for den empiriske forskningsinteressen, er: Hvordan forstås og utformes ledelse som organisatorisk oppgave og rolle i offentlige og kirkelige og diakonale organisasjoner? Hvordan formes og utøves ledelse som praksis i samspill mellom leder, øvrige aktører og organisasjonskontekst? Programmet har hatt to ulike løp. Det ene består av kvantitative studier av lederroller, mens det andre bruker observasjons- og intervjuundersøkelser av lederes hverdagspraksis. Prosjektet har resultert i om lag 40 mastergradsoppgaver med hovedvekt på kirkelige, diakonale og helse- og sosialfaglige organisasjoner.

Forskningsprogrammet poengterer at ledelse best forstås med utgangspunkt i empiri. Ledelse er innvevd i lederes daglige aktiviteter. Eksempelvis har Henry Mintzberg (2009) gjennomgående benyttet observasjon, lederes egenrapportering og intervjuer som metode. Mintzberg (1973) påviste forskjeller, som er bekreftet i senere studier, mellom antakelser om lederjobben og dens faktiske innhold. 
Noen sentrale funn er felles for alle studiene, og i samsvar med internasjonale studier innenfor managerial work-tradisjonen med Mintzberg som en sentral forsker. Ledere ivaretar svært mange aktiviteter i løpet av en lang og hektisk arbeidsdag (Askeland et al., 2015; Sirris, 2016). De fleste aktivitetene er korte, noe som fører til en fragmentert og sammensatt arbeidsdag. Ofte foregår flere aktiviteter samtidig, eller det veksles mellom ulike episoder av hver aktivitet. Lederne møter ofte avbrytelser som forstyrrer i en aktivitet. Egenavbrytelse er også vanlig. Det er mye som skjer i ikke-planlagte møter, og ikke minst i forkant eller i etterkant av planlagte møter. Dette kan være tilfeldige samtaler som danner beslutningsarenaer. Ledere initierer kontakt gjennom å oppsøke andre. De tar beslutninger fortløpende, uttrykker støtte eller holder den tilbake. Omfang av tid i møter øker med nivå; jo høyere ledelsesnivå, jo mer planlagte møter. På lavere ledelsesnivå minker tid på eget kontor og til administrative oppgaver med nærhet til operativt arbeid. Lederne blir da tettere på virksomheten, og flere er samtidig utøvende i faget. Kjernevirksomhet preger ledelsespraksis idet ledere også har faglig ansvar. Det forutsetter kjennskap til sektor, bransje og virksomhet. Ledernivå avgjør hvordan helhetsansvar og ansvar for verdier forstås, men ledere på alle nivåer opplever handlingsrom. Ledere ønsker å prioritere langsiktighet, men bruker tid på kortsiktige oppgaver. Mye tid går med til administrative oppgaver. Ansvar for drift, personal, utvikling, orden - og ikke minst helhet.

Denne empiriske forskningen kompletterer mer normative og kognitive tilnærmingsmåter i ledelsesfaget. Et viktig premiss i forskningsprogrammet LIP, er at når vi vet hva ledere faktisk gjør, forstår vi mer av hva ledelse er. Ledelse må ta høyde for kontekst og særpreg ved arbeidet. Det har også vært et mål å forklare hvordan lederjobben henger sammen som en helhet, og da bør arbeidshverdagen studeres. Vi presenterer i det følgende utvalgte empiriske studier av norske kirkeledere.

\section{Soknepresters og kirkevergers lederroller (1998)}

Begrepet arbeidsorientering har bakgrunn i lederundersøkelser med vekt på rolleteori. Lederrolleundersøkelsen i 1998 bygger på Adizes’ 
firedelte rolletypologi som ledelsen må ivareta: produsent, administrator, entreprenør og integrator. Spørreskjemaet ble sendt til 190 menigheter; 112 rådsledere, 116 sokneprester og 138 kirkeverger svarte. Informantene vurderte viktigheten av ulike kategorier lederfunksjoner. Skalaen er fra 1 til 7, hvor 1 betyr at noe er svært lite viktig, mens 7 betyr at noe er svært viktig.

Tabell 2. Soknepresters og kirkevergers lederroller i 1998 (Askeland, 1998, s. 222)

\begin{tabular}{lcccc}
\hline & Entreprenør & Produsent & Integrator & Administrator \\
\hline Felles vurdering av viktighet & 6,1 & 5,8 & 6,5 & 5,3 \\
Felles tidsbruk & 4,0 & 4,8 & 4,9 & 4,6 \\
$\begin{array}{l}\text { Soknepresters vurdering av } \\
\text { viktighet }\end{array}$ & 6,2 & 5,4 & 6,6 & 4,8 \\
$\begin{array}{l}\text { Soknepresters tidsbruk } \\
\text { Kirkevergers vurdering av }\end{array}$ & 5,3 & 4,8 & 5,3 & 3,8 \\
viktighet & 3,8 & 6,0 & 6,5 & 5,5 \\
Kirkevergers tidsbruk & 3,2 & 5,2 & 5,2 & 5,4 \\
\hline
\end{tabular}

Undersøkelsen i 1998 viste at sokneprester og kirkeverger ga ulik skår til lederrollene. Både sokneprester og kirkeverger oppga at integratorrollen var viktigst, siden begge har lederansvar overfor ansatte. Kjønnsfordelingen er helt lik hva gjelder vurderingen av viktigheten av integratorrollen $(6,5)$. Det samme gjelder også vurderingen av tidsbruk $(4,9)$. Sokneprestene vekter relasjoner mer enn de andre, men mener selv at de bruker lite tid på det. De mener selv å bruke svært mye tid på administrasjon. Samtidig som integratorrollen er antatt å være internt orientert, er den like fullt orientert mot utvikling, men da slik at utvikling skjer gjennom at medarbeidere støttes, motiveres og utvikles. Entreprenørrollen kom på andreplass i ledernes vurdering av rollenes betydning. Sokneprestene tilla begge roller noe høyere vekt enn kirkevergene, som rangerte særlig entreprenørrollen markert lavere. Sokneprester profilerte seg på entreprenørrollen; å utvikle menigheten og dens tjenester for å nå stadig nye mennesker. Rollen er også eksternt orientert mot at den lokale kirkes tjenester møter omgivelsenes behov. Produsentrollen ble rangert på tredjeplass. Forskjellene var betydelige idet kirkevergene vektla denne rollen, mens sokneprestene prioriterte ned produsentrollen. Den samme 
tendensen gjorde seg gjeldende for administratorrollen og gjelder også tidsbruk for hver rolle. Både sokneprester og kirkeverger oppga å bruke svært mye tid på integratorrollen. Samlet antas sokneprester og kirkeverger å ha omtrent samme tidsbruk på relasjoner og utvikling av medarbeidere. Kirkevergene fremstod som lederkategorien som brukte mest tid på produsent- og administratorrollen, i motsetning til sokneprestene. En slik profil kan indikere at kirkevergenes stilling var den som tydeligst ble forankret i en forståelse av at lederrollen ivaretas i og overfor den lokale kirke som organisasjon. Samtidig er disse rolleprofilene i større grad orientert mot stabilitet.

En hovedkonklusjon fra undersøkelsen var at rolleutformingen og rolleatferden som fremgikk av materialet, viste supplerende lederroller blant kirkeverger og sokneprester. Sokneprestene utformet sin rolle langs en ekstern utviklingsorientering som ikke ble utsatt for konkurranse fra kirkevergene. Kirkevergene var de som sterkest profilerte seg på stabilitetsorientering, både internt og eksternt. Et overlappende felt, og kanskje et konkurranseforhold, var relasjonen til de ansatte. Sokneprester og kirkeverger profilerte seg omtrent likt på integratorrollen, både når det gjaldt viktighet og tidsbruk.

\section{Prosters og kirkevergers lederroller etter 1998}

Masteroppgaver som undersøkte dekirkelige lederrollene ble skrevet rundt ti år senere, i perioden fra 2007-2010. Disse studiene reflekterer utviklingen i nyorganiseringen av prestetjenesten gjennom å studere prosterollen. En av disse undersøkelsene inkluderte både proster og kirkeverger og rapporterte viktige endringer siden 1997. Både proster og kirkeverger syntes å ha nedprioritert entreprenørrollen i viktighet og tidsbruk (Skårberg, 2007). Integratorrollen skåret høyest for begge grupper, og overtok, sammenlignet med 1998-studien, for administratorrollen som viktigst for kirkevergene. Disse lederkategoriene synes også i 2007 å videreføre en delt profilering der kirkevergene vektla administratorrollen mens prostene betonte produsentrollen. Også i studien av endringer i prosterollen fant Tormod Stene Hansen (2007, s. 70) i sin masteroppgave at prostene vektla integratorrollen sterkest, men at prostene hadde styrket sitt fokus 
på produsentrollen. Også han rapporterer om en synkende tendens til å ivareta entreprenørrollen blant prostene. Prostenes vektlegging av integrator- og produsentrollen bekreftes i ytterligere to studier (Gunnarson, 2009; Løfsgård, 2007) som en markant tendens. Øyvind Hauken (2007) tegner i sin masteroppgave det samme bildet, men hans studie undersøkte relasjonen mellom sokneprester og kirkeverger. Han finner lignende arbeidsdeling hvor kirkevergene ivaretar administratorrollen og sokneprestene i noe større grad ivaretar entreprenør- og produsentrollen. Begge lederkategorier ivaretar integratorfunksjonen overfor medarbeidere.

Enda en studie (Holmsen Krogh, 2010) om sokneprester og kirkeverger dokumenterer den samme utviklingen. Prestenes tidsbruk i entreprenørrollen hadde minket, mens kirkevergenes vekt på entreprenørrollen var $ø k t$ betydelig. Igjen tok integratorrollen mest tid hos begge lederkategorier, mens kirkevergene brukte mye tid både på administrator-, integrator- og produsentrollene (Holmsen Krogh, 2010, s. 36).

Oppsummert viser studiene fra 2007 til 2010 tydelige utviklingstrekk for de ulike lederrolleprofilene. Bente Skårberg (2007, s. 59) fant det overraskende i sin masteroppgave at prostenes nye arbeidsgiveransvar for prestene ikke medførte økt vekt på administratorrollen. Tilsvarende konkluderte Kolbjørn Gunnarson (2009, s. 75) i sin masteroppgave med at prostene bare delvis ivaretok sitt lederansvar slik det var formulert i ny tjenesteordning. Arne Løfsgård (2007, s. 82) påpekte i masteroppgaven at prostene i praksis fungerte mer som agenter for biskop og bispedømmeråd enn de selv uttrykte. Astrid Holmsen Krogh (2010, s. 55) fant i sin studie at mens sokneprester hadde økt sin tidsbruk på administrasjon, hadde kirkevergene i større grad tatt tak i utadrettede utviklingsoppgaver. Hun stilte spørsmål om en ikke heller burde funnet en noe annen tendens, nemlig at sokneprester skulle få frigjort tid til nettopp utadrettede og ikke innadrettede, administrative oppgaver.

Samlet viser denne gjennomgangen av LIP-prosjektene markante endringer av rollemønstre det første tiåret som dekkes av denne artikkelen. Endringer i tjenesteordningen for proster resulterte i sterkere vekt på arbeidsgiveroppgaver. Utviklingen medførte mer tidsbruk på administrative oppgaver på tross av prostenes lave skår på viktigheten av 
administratorrollen. I særlig grad synes dette å ha gått ut over tid brukt på produsentrollen, mens de fremdeles både vektla og brukte tid på rollen som integrator. Den tydeligste trenden blant kirkevergene var den økende vekten og tidsbruken på entreprenørrollen. I 1997 ble det antatt at denne rollen var lavt prioritert grunnet en betydelig administrativ belastning med etablering av styringsstrukturer og prosedyrer knyttet til overtakelse av arbeidsgiveransvar fra kommunene. I tillegg synes kirkevergene midtveis i perioden å bruke noe mer tid enn sine geistlige lederkolleger på produsentrollen og i enkelte studier også integratorrollen. Av de lokale kirkelige lederroller bruker kirkevergene fremdeles klart mest tid på administratorrollen (jf. og kapittel 10, s. 233-235 for en utdypende gjennomgang).

I en oppfølgingsstudie viste Askeland (2016) at proster og kirkeverger likedannes som ledere, både når det gjelder forventningene som stilles og tidsbruk på ulike rolleprofilene. For hver gruppe er det tydelige endringer fra de tidligere undersøkelsene (se tabell 3).

Tabell 3. Gjennomsnitt for grad av opplevd forventning og angitt tidsbruk for ulike lederfunksjoner for proster og kirkeverger, på en skala fra 1-5 der 1 er lavest og 5 høyest (Askeland, 2016, s. 14)

\begin{tabular}{lccccc}
\hline & $\begin{array}{c}\text { Institusjonell } \\
\text { leder }\end{array}$ & Tjenesteutvikler & Dirigent & Integrator & Mellommann \\
\hline Forventet & & & & & \\
Prost & 4,1 & 3,5 & 4,0 & 4,3 & 3,6 \\
Kirkeverge & 4,0 & 3,9 & 4,3 & 4,3 & 4,1 \\
\hline Tidsbruk & & & & & \\
Prost & 3,6 & 3,3 & 3,8 & 4,2 & 3,2 \\
Kirkeverge & 3,7 & 3,8 & 3,9 & 4,1 & 3,7 \\
\hline
\end{tabular}

Kirkeverger synes å oppleve et bredere og sikrere institusjonelt grunnlag for lederrollen, og har samtidig mer oppmerksomhet på utvikling og fornying. Prostene rapporterer en svakere utviklingsprofil enn sokneprestene oppgav i 1998 og nivået som dokumenteres i studier rundt 2010. Prostene legger mer vekt på dirigentrollen, som også inneholder en administrativ komponent. Som tidligere vektlegges integratorrollen, som utgjør en distinkt kirkelig lederorientering. Både kirkeverger og proster vektlegger institusjonell ledelse, men med ulike nyanser. Mens prostene profilerer seg noe tydeligere på å fremme kirkens formål og det 
å sette verdier på dagsorden, skårer kirkevergene noe høyere på å bidra til samlede resultater og et helhetlig blikk for ulike enheters bidrag til helheten.

Identitetsaspektet har ikke blitt fanget eksplisitt opp i de refererte studiene, men har vært vurdert indirekte ut fra vektlegging av de ulike lederprofilers viktighet og grad av opplevd forventning. Hovedinntrykket er at kirkevergene tidlig utviklet en rollebevissthet og identitet som ledere og at prostene også har en etablert bevissthet om lederrollen. Kirkevergene rapporterte å ha en klar kirkelig lederidentitet, og at de opplever å bidra til at kirkens verdier og oppdrag settes på dagsorden. Kirkevergenes rolle beskrives mer utfyllende i neste kapittel i denne boken.

\section{Soknepresters ledelse i praksis (2013)}

Stephen Sirris (2013) undersøkte soknepresters arbeidsdager som del av prosjektet Ledelse i praksis. Når det gjelder aktivitetsmønstre, viser tabellen under sammenligning med Mintzbergs (1973) toppledere i næringslivet, en amerikansk undersøkelse av pastorer (Kuhne \& Donaldson, 1995), en svensk studie av næringslivsledere (Tengblad, 2001) og en norsk undersøkelse av baptistpastorer (Sandtorp, 2011).

Tabell 4. Lederes tidsbruk angitt i prosent (Sirris, 2016, s. 74)

\begin{tabular}{lccccc}
\hline & $\begin{array}{c}\text { Næringslivs- } \\
\text { ledere } \\
\text { (Mintzberg, } \\
\text { 1971) }\end{array}$ & $\begin{array}{c}\text { Pastorer } \\
\text { (Kuhne \& } \\
\text { Donaldson, } \\
\text { 1995) }\end{array}$ & $\begin{array}{c}\text { Næringslivs- } \\
\text { ledere } \\
\text { (Tengblad, } \\
\text { 2001) }\end{array}$ & $\begin{array}{c}\text { Pastorer } \\
\text { (Sandtorp, } \\
\text { 2011) }\end{array}$ & $\begin{array}{c}\text { Prester } \\
\text { (Sirris, } \\
\mathbf{2 0 1 3 )}\end{array}$ \\
\hline Planlagte møter & 59 & 46 & 45 & 71 & $\mathbf{4 2}$ \\
$\begin{array}{l}\text { Ikke-planlagte } \\
\text { møter }\end{array}$ & 10 & 8 & - & 0 & $\mathbf{2 2}$ \\
Kontorarbeid & 22 & 23 & 24 & 21 & $\mathbf{2 1}$ \\
Telefoni & - & 6 & 21 & - & $\mathbf{4}$ \\
«Tours» (uformelle & 3 & 5 & 2 & 4 & $\mathbf{3}$ \\
runder og småprat) & & 12 & 8 & 4 & $\mathbf{8}$ \\
Reiser & 6 & 100 & 100 & 100 & $\mathbf{1 0 0}$ \\
\hline Total & 100 & & & & \\
\hline
\end{tabular}


Prestetjenestens egenart førte til en særskilt underkategorisering hos Sirris. Både planlagte møter og ikke-planlagte møter skjelner mellom faglige møter og administrative møter. Tilsvarende blir kontorarbeid nyansert som faglig eller administrativt. Disse kategoriene indikerer fagledelse hvor ledelse ligger innbakt i selve profesjonsoppgavene. Fagledelse fanges ikke helt opp i lederrolletypologiene som bygger på et funksjonalistisk syn på ledelse som et organisatorisk forankret mandat (Adizes, 1980). Oppsummerende blir prestehverdagen beskrevet slik (Sirris, 2016, s. 86):

- Ni timers arbeidsdag med stor arbeidsmengde

- Høyt tempo, avbrudd, variasjon

- $2 / 3$ av tiden er i relasjoner til andre, $1 / 3$ er brukt individuelt

- $13 \%$ av tiden er utøvende prestetjeneste

- $1 / 4$ av tiden er administrasjon

- Halvparten av tiden er faglig orientert, og resten er organisatorisk orientert

\section{Diakonens lederroller (2005 og 2015)}

En diakon er leder av kirkens omsorgstjeneste. Diakoni forstås som evangeliet i handling og uttrykkes gjennom nestekjærlighet, inkluderende fellesskap, vern om skaperverket og kamp for rettferdighet. Sosiologen Olav Helge Angell (2011) har på grunnlag av diakonenes arbeid utviklet Adizes' typologi og gitt nye navn. Entreprenør er blitt brobygger, mens produsent er blitt leverandør. Brobyggerrollen er orientert eksternt og mot å skape legitimitet. Dette kan skyldes at velferdsorganisasjoner ikke nødvendigvis samsvarer med verdier i omgivelsene. Diakonen jobber utadvendt i lokalsamfunnet, slik det også kommer til uttrykk i leverandørrollen, hvor man er opptatt av oppgavedimensjonen. Diakonenes lederroller er studert gjennom to spørreundersøkelser i 2005 og i 2015. Begge årene gikk undersøkelsen til omkring 300 diakoner, hvorav halvparten svarte. Førstelektor i diakoni, Kari Jordheim (2018), finner at diakonene skårer høyt på integratorfunksjonen og som brobyggere. Det har også vært en utvikling over disse 
ti årene ved at diakonene opplever at administratorfunksjonen er styrket. Det er også en liten fremgang hva gjelder entreprenørrollen. Tabellen under viser fordeling av svar. Det var mulig å krysse av for flere alternativer.

Tabell 5. Diakonens lederroller. Prosent (Jordheim, 2018, s. 21)

\begin{tabular}{lcc}
\hline & $\mathbf{2 0 0 5}$ & $\mathbf{2 0 1 5}$ \\
\hline Produsent & 34 & 14 \\
Administrator & 11 & 26 \\
Entreprenør & 25 & 28 \\
Integrator & 70 & 49 \\
\hline
\end{tabular}

Diakonenes lederroller og utviklingen av typologien er et eksempel på at kjernevirksomhet og fagets karakter får følger for hvordan ledelse konseptualiseres. Diakonene identifiserer seg mest med integratorrollen. Dette er naturlig ut fra diakonenes arbeidsfelt med vekt på relasjoner, nettverksbygging og oppfølging av mennesker (Jordheim, 2018).

\section{Prosters identitet og roller hybridiseres (2019)}

Hittil har vi beskrevet ledelse i praksis og den nære sammenhengen med lederrolleundersøkelser. Rolle betegner ytre forventninger og jobbkrav, mens identitet refererer til selvforståelse. Flere av studiene operasjonaliserer rolle gjennom tidsbruk, oppgaver og ansvar. Identitet kan dokumenteres gjennom lederes beskrivelse av egen selvforstålse. Det er ikke gitt at det er samsvar mellom identitet og rolle, selv om dette ofte tas for gitt i flere av studiene. Det er ingen automatikk i at mye tid brukt på å være administrator betyr at man identifiserer seg med den funksjonen. Lederes identiteter og idealer korresponderer ikke alltid med innholdet $\mathrm{i}$ arbeidet deres. Dette forholdet mellom rolle og identitet er påpekt og utforsket i norsk kirkekontekst når det gjelder ledelseslogikk og profesjonslogikk (Sirris, 2019). Distinksjonen er interessant, fordi profesjonsutøvere ofte har en sterk faglig identitet. Når de går inn i en lederrolle, innebærer det en formell posisjon hvor man får ansvar for hele organisasjonen og ikke 
bare et avgrenset fagområde. I et funksjonalistisk perspektiv er ofte rollen forutbestemt, mens rolleinnehaveren i et interaksjonistisk perspektiv i høyere grad må utforme rollen sin.

Sirris (2019) intervjuet ni proster i et bispedømme, hvorav tre ble observert i en arbeidsuke hver. Når det gjelder identitet, kan prostenes narrativer plasseres på en skala fra profesjon til ledelse. Det var fokus på pastoral identitet og innsats for å holde oppmerksomheten på kirkens oppdrag. Kollegiale relasjoner ble understreket. Artikkelen skjelner mellom dette som primær identitet, og lederidentitet som sekundæridentitet. Lederidentitet innebar å være arbeidsgiver, sjef og administrator. Arbeidsgiveransvaret ble høyt prioritert, og man ønsket å lede gjennom relasjoner og på nært hold. En karakterisk utsagn var: «Vi er først og fremst prester, så ledere, og deretter arbeidsgivere som utøver administrasjon og byråkrati» (Sirris, 2019, s. 24). Oppsummert hadde prostene fortsatt sterk profesjonsidentitet, men dette utelukket ikke en voksende lederidentitet. Hva gjelder rolle, var plasseringen omvendt. Her var lederrollen primær, mens profesjonsrollen kom sekundært. Prostene måtte prioriterte administrasjon gjennom prioritering av arbeidsgiveransvaret. Ytre rammer avgjorde hva de kunne gjøre. Dernest var tidsbruk til å motivere og inspirere presteskapet viktig. Administrasjon ble tydelig kontrastert med kjernevirksomhet. Et typisk sitat her er:

En dyktig prost har relasjonell kompetanse. Administrasjon og teologisk kompetanse kommer sekundært. Administrasjon og orden er avgjørende. Vår oppgave går fra det prosaiske - se til at alle arbeider, hjelpe dem å organisere arbeidstid og ferie. De ytre rammene. I tillegg, hvordan vi utfører arbeidet. Arbeidsgiveransvar utgjør mesteparten av jobben min. (Sirris, 2019, s. 54)

Studien er en sammenligning med helseledere. Den finner at prostene er mer resistente mot styringslogikk og organisatorisk kontroll enn helselederne. Bispedømmet er desentralisert og distribuert. Sirris (2019, s. 10) plasserer kirkelederne på to akser i et rammeverk. Den første aksen er identitet, og den andre er lederrolle. Her blir det fire typer. 


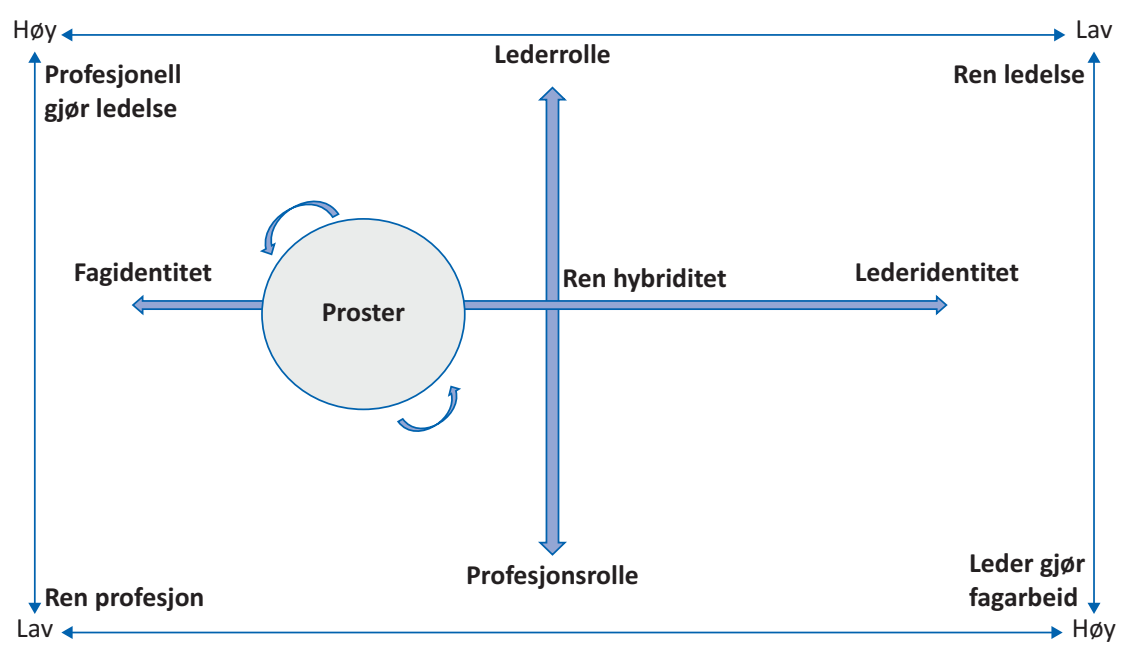

Figur 1. Identitet og roller (Sirris 2019, s. 10)

I midten er en fullstendig hybrid, noe Sirris (2019) ikke finner empirisk belegg for. Prostene befinner seg ikke innenfor en av disse fire typene, men et sted midt på aksene - selvsagt med ulike individuelle forskjeller og preferanser. Som gruppe prioriterer prostene primært en profesjonsidentitet og en lederrolle. Helselederne som deltok i undersøkelsen hadde derimot en primær lederidentitet og lederrolle. For kirkelederne utgjør dette ikke nødvendigvis et problem, men det er en spenning mellom identitet og hva man faktisk gjør av arbeidsoppgaver. Kort sagt: ledelse trumfer profesjon. Dette speiler en generell samfunnsutvikling hvor arbeidslovgivning vokser og regulerer rettigheter og plikter i arbeidslivet. Å være arbeidsgiver er omfattende og tar tid.

\section{Konklusjon}

Det er gode grunner for å studere ledelse i praksis i sammenheng med roller og identitet. For det første gir observasjonsstudier førstehåndskjennskap til lederes praktiske arbeid. Hva man fyller tiden med, er et uttrykk for hva som er viktig. Videre er dette en god tilnærming til ledernes tause kunnskap. Hvis man ikke har et ledelsesfaglig språk, vil observasjon og intervjuer med utgangspunkt $i$ arbeidshverdagen gi et godt utgangspunkt for samtale. 
Perioder med organisatorisk endring og institusjonell pluralisme er særlig egnet til å studere utviklingstrekk i forholdet mellom etablert rollebevissthet og identitet som leder. Men å være leder handler også om å få andre med seg og skape oppslutning. Man må bli oppfattet som leder. Lederfunksjoner kan ivaretas formelt, men også uformelt. Roller har et «skript» som foreskriver hva omgivelsene oppfatter som passende, og dermed knyttet til rammer og strukturer.

Vi har presentert funn fra enkelte stillingskategorier uten en formell lederstilling, eksempelvis diakoner og prester. Disse har mye fagledelse som en naturlig del av jobben. I tillegg ivaretar de ledelsesfunksjoner på vegne av menigheten utad. Studiene viser diakonenes vekt på brobyggerrollen og sokneprestenes entreprenørrolle. Et viktig poeng er at eksempelvis prestene bruker halve arbeidstiden på organisatoriske oppgaver (Sirris, 2016). Sokneprestene erkjenner et ansvar for menigheten som helhet og er aktive i stabssammenheng, råd og utvalg, og i kommunikasjon og samhandling med kirkeverge.

For prestene, både sokneprester og proster, har utfordringen vært en overgang fra en sterk faglig rolle som innebar mye uformelt lederansvar til en situasjon der prostene tydelig ble definert som mellomledere i kirken. Kirkevergerollen var før 1996 noe uklar hva gjelder ansvarsområde og som mellomstilling mellom kirke og kommune. Gjennom kirkeloven i 1996 ble den tydelig som lederstilling. Studiene over tid viser en markert utvikling for kirkevergene.

Forskningsprogrammet Ledelse $i$ praksis starter med arbeidshverdagen til ledere og deres aktiviteter og tidsbruk. Flere av studiene benyttet rolletypologier med basis i Adizes (1980) og de videreutviklinger som har kommet siden. Færre har lagt vekt på identitet. Her ligger et potensial for videre forskning. Å skjelne tydeligere mellom rolle og identitet kan gi et mer nyansert bilde hvem ledere forstår seg selv som, og hva andre forventer av dem og hvordan de faktisk fyller tiden sin. En viktig innsikt hos Sirris (2019), er at lederne prioriterer både profesjonslogikk og ledelseslogikk avhengig av organisatorisk kontekst. Lederne søker å forbedre sin organisasjon slik at den lever ut sitt oppdrag. Det gjør prostene ved å nære profesjonen. Disse perspektivene er ikke motstridende, men kan 
derimot gi et mer utfyllende bilde av hva det vil si å være leder i en kompleks organisasjon.

Et viktig anliggende, også for praktikere, er hvordan man som hybridledere - profesjonsutøvere i lederstilling, eksempelvis prostene balanserer og integrerer ulike faglige og ledelsesmessige roller. Å være leder tar mye tid og oppmerksomhet. Utviklingen vil vise hvordan ledere identifiserer seg med ulike dimensjoner i arbeidet. Hvordan hybridiseringer av både identiteter og roller utfolder seg i ulike profesjoner og ledere i kirken, er et aktuelt forskningstema.

Avslutningsvis i et bokkapittel som handler om kirkelige lederroller og identitet, kreves bevissthet om identifikasjon med roller. Rolleoverbelastning kan føre til utbrenthet og monomani. En kirkeleder er tjent med å være bevisst på at identiteten ikke bare hviler i det man gjør. Kirkens vitnesbyrd er at vår identitet er grunnfestet et annet sted.

\section{Referanser}

Adizes, I. (1980). Lederens fallgruver og hvordan man unngår dem (N. Hoff, Overs.). Hjemmet fagpresseforlaget. (Opprinnelig utgitt 1979)

Albert, S. \& Whetten, D. A. (1985). Organizational identity. I L. L. Cummings \& B. M. Staw (Red.), Research in organizational behavior (s. 263-295). JAI Press.

Alvesson, M. \& Willmott, H. (2002). Identity regulation as organizational control: Producing the appropriate individual. Journal of Management Studies, 39(5), 619-644. https://doi.org/10.1111/1467-6486.00305

Angell, O. H. (2011). Leiarar og leiarroller i den lokale kyrkja: Diakonen som leiar i kyrkjelyden. Nordiske Organisasjonsstudier, 13(4).

Ashforth, B. E. \& Kreiner, G. E. (1999). «How can you do it?»: Dirty work and the challenge of constructing a positive identity. Academy of Management Review, 24(3), 413-434. https://doi.org/10.5465/amr.1999.2202129

Askeland, H. (1998). Ledere og lederroller. Om ledelse og lederroller i den lokale kirke. Tapir.

Askeland, H. (2016). Ledelse og lederes roller i Den norske kirke.

Lederrolleundersøkelsen 2016 i et tyveårsperspektiv. Tidsskrift for Praktisk Teologi, 33(2), 5-19. https://journals.mf.no/tpt/article/view/5197

Askeland, H., Blomander, C. \& Aasen, A. (2015). Jakten på ledelse i praksis.

Semistrukturert følge-observasjon som metode innenfor ledelsesforskning.

Nordiske Organisasjonsstudier, 17(1), 3-30. 
Battilana, J. \& D’Aunno, T. (2009). Institutional work and the paradox of embedded agency. I T. Lawrence, R. Suddaby \& B. Leca (Red.), Institutional work: Actors and agency in institutional studies of organizations (s. 31-58). Cambridge University Press.

Blizzard, S. W. (1956). The minister's dilemma. Christian Century, 73, 508-510.

Cameron, K. S., Quinn, R. E., DeGraff, J. \& Thakor, A. V. (2014). Competing values leadership. Edward Elgar Publishing.

Giddens, A. (1991). Modernity and self-identity. Self and society in the late modern age. Polity Press.

Gunnarson, K. L. (2009). Prosten - prestenes leder. En undersøkelse av to prosters lederroller overfor prester, i lys av ny tjenesteordning for proster [Masteroppgave, Diakonhjemmet høgskole]. VID Open. http://hdl.handle.net/11250/98399

Hansen, T. S. (2007). Prosten som leder. Undersøkelse om endringer i prosterollen som følge av ny tjenesteordning [Masteroppgave]. Diakonhjemmet høgskole.

Hansson, P. \& Andersen, J. A. (2008). Vicars as managers revisited: A comparative study. Nordic Journal of Religion and Society, 21(1), 91-111.

Hauken, Ø. (2007). Todelt ledelse i den lokale kirke [Masteroppgave, Diakonhjemmet høgskole]. VID Open. https://vid.brage.unit.no/vid-xmlui/bitstream/handle/ $11250 / 98409 / \% C_{3} \% 83 \% C_{2} \% 98 y v i n d \% 20 H a u k e n \_V B L . p d f$ ? sequence $=1 \&$ is Allowed $=\mathrm{y}$

Hedin, M. (2009). Vad gör kyrkoherden? [Magisteroppgave, Universitetet i Uppsala]. DiVA. http://urn.kb.se/resolve?urn=urn:nbn:se:uu:diva-107461

Ibarra, H. (1999). Provisional selves: Experimenting with image and identity in professional adaptation. Administrative Science Quarterly, 44(4), 764-791. https://doi.org/10.2307/2667055

Jordheim, K. (2018). Diakonen som leder. Tidsskrift for Praktisk Teologi, 2, 16-28. https://journals.mf.no/tpt/article/view/5372

Järventie-Thesleff, R. \& Tienari, J. (2016). Roles as mediators in identity work. Organization Studies, 37(2), 237-265. https://doi.org/10.1177/0170840615604500

Krogh, A. H. (2010). Det som ikke skjer lokalt, skjer ikke. Om ledelse og lederroller på lokalplanet i Den norske kirke [Masteroppgave, Diakonhjemmet høgskole]. VID Open. http://hdl.handle.net/11250/98421

Kuhne, G. W. \& Donaldson, J. F. (1995). Balancing ministry and management. An exploratory study of pastoral work activities. Review of Religious Research, $37(2)$, 147-163. https://doi.org/10.2307/3512398

Løfsgård, A. (2007). Ledelse av prestetjenesten på prostiplan [Masteroppgave, Diakonhjemmet høgskole]. VID Open. http://hdl.handle.net/11250/98381

McAdams, D. P. \& McLean, K. C. (2013). Narrative identity. Current Directions in Psychological Science, 22(3), 233-238. https://doi.org/10.1177/0963721413475622 Mintzberg, H. (1973). The nature of managerial work. Harper \& Row. 
Mintzberg, H. (2009). Managing. Berrett-Koehler.

Quinn, R. E. \& Rohrbaugh, J. (1983). A spatial model of effectiveness criteria: Towards a competing values approach to organizational analysis. Management Science, 29(3), 363-377. https://doi.org/10.1287/mnsc.29.3.363

Sandtorp, B. (2011). Hvordan utøves pastoryrket i baptistmenigheter? - Et intervju- og observasjonsstudium (Masteroppgave, Diakonhjemmet høgskole]. VID Open. http://hdl.handle.net/11250/98423

Schmid, H. (2010). Organizational change in human service organizations. I Y. Hasenfeld (Red.), Human services as complex organizations (s. 455-479). Sage Publications.

Simpson, B. \& Carroll, B. (2008). Reviewing «role» in processes of identity construction. Organization, 15(1), 29-50. https://doi.org/10.1177/1350508407084484

Sirris, S. (2013). Pastoral ledelse i praksis. En empirisk undersøkelse av forholdet mellom soknepresters utøvelse av ledelse og forståelse av egne lederroller [Masteroppgave, Diakonhjemmet høgskole]. VID Open. http://hdl.handle. net/11250/98523

Sirris, S. (2016). Arbeidsdager mellom profesjon, ledelse og organisasjon Soknepresters tidsbruk og aktivitetsmønstre. Teologisk Tidsskrift, 4(1), 60-88. https://doi.org/10.18261/issn.1893-0271-2016-01-05

Sirris, S. (2019). Managers negotiating identities. Hybridizing professionalism and managerialism in faith-based health organizations and in religious organizations [Doktorgradsavhandling, VID vitenskapelige høgskole]. VID Open. http://hdl. handle.net/11250/2632293

Skårberg, B. (2007). Der linjene møtes. Prost og kirkeverge om enhetlig ledelse i den lokale kirke [Masteroppgave, Diakonhjemmet høgskole]. VID Open. http://hdl. handle.net/11250/98407

Stewart, R. (1989). Studies of managerial jobs and behaviour: The ways forward. Journal of Management Studies, 26(1), 1-10. https://doi. org/10.1111/j.1467-6486.1989.tboo713.x

Strand, T. (2001). Ledelse, organisasjon, kultur. Fagbokforlaget.

Stryker, S. \& Burke, P. J. (2000). The past, present, and future of an identity theory. Social Psychology Quarterly, 63(4), 284-297. https://doi.org/10.2307/2695840

Sveningsson, S. \& Alvesson, M. (2003). Managing managerial identities:

Organizational fragmentation, discourse and identity struggle. Human Relations, 56(10), 1163-1193. https://doi.org/10.1177/00187267035610001

Tengblad, S. (2001). Examining the stability of managerial behavior. A replication of Henry Mintzbergs classic study 30 years later (Gothenburg Research Institute rapport 2001:6). GUPEA. http://hdl.handle.net/2077/3036 



\title{
KAPITTEL 10
}

\section{Kirkevergens lederrolle}

\author{
Harald Askeland
}

VID vitenskapelige høgskole

\section{Mildrid Fiske}

VID vitenskapelige høgskole

\section{Åslaug Styve Mjånes}

VID vitenskapelige høgskole

\begin{abstract}
A central and specific aspect of the Church of Norway is its legally grounded democratic structure of autonomous local congregations. This local congregational organization complements the traditional synodal and/or episcopal structures of other churches. The institution of the church warden, dating back to medieval times, has been transformed into a general managerial position on behalf of the joint parish councils in each municipality. The chapter traces the roots of this position and reviews two decades of research on church wardens' conception of managerial leadership roles. This review show that church wardens have a clear managerial identity and balance differing demands on managerial work. They are also key agents in communicating and interacting with their local communities and municipal authorities, securing legitimacy and resources.
\end{abstract}

Keywords: church warden, identity, institutional, management, roles

\section{Introduksjon}

Den norske kirke må kontinuerlig gjennomtenke hvordan den realiserer sitt oppdrag, sine verdier og sitt formål som selvstendig folkekirke. Denne type spørsmål er naturlig å stille ut fra den reform- og nyorganiseringsperiode kirken er i, med avvikling av statskirken og etablering av nye legale rammer for tros- og livssynsvirksomhet. Slike spørsmål stilles i

Sitering av denne artikkelen: Askeland, H., Fiske, M. \& Mjånes, Å. S. (2021). Kirkevergens lederrolle. I S. Sirris \& H. Askeland (Red.), Kirkelig organisering og ledelse: Et verdibasert og praksisorientert perspektiv (Kap. 10, s. 223-241). Cappelen Damm Akademisk. https://doi.org/10.23865/noasp.129.ch1o

Lisens: CC BY-NC-ND 4.0 
ikke bare i Den norske kirke, men også i øvrige kirkesamfunn (Askeland, 2016; Frank, 2006; Jenssen, 2018; Sirris, 2016). I dette kapitlet vil vi rette oppmerksomheten mot kirkevergens posisjon i et historisk og samtidig perspektiv. Kunnskap om de aktuelle lederroller i kirken er et viktig grunnlag for kontinuerlig utviklingsarbeid og for de tiltak som sikrer kompetanse for ledere.

Utgangspunktet for å forstå og tilordne lederansvar ligger i kirkens oppdrag, da særlig kirken som folkekirke. En slik forståelse fordrer ledelse som både håndterer ledelsesfaglige, kirkefaglige og ordningsmessige anliggender. Samtidig må ledelse sees som en kompleks og kontekstuell praksis som er innrammet av samfunnsmessige krav og reguleringer. En slik ledelsesforståelse må særlig forankres i det oppdrag og de verdier folkekirken søker å realisere.

I snart 25 år har kirkevergestillingen vært lovfestet som daglig leder i den lokale kirke på kommunenivå, mens kirkevergenes århundrelange rolle som lokale kirkeledere har vært lite undersøkt. Dette kapitlet reiser følgende spørsmål: Hvordan har kirkevergerollen utviklet seg og hvordan profilerer kirkeverger seg som lokale kirkeledere?

Kapitlet bygger på datamateriale og videreutvikler innsikter og konklusjoner fra et forskningsprosjekt ved VID vitenskapelige høgskole: Ledelse og lederroller i praksis (LIP). ${ }^{1}$ Siden 2006 har prosjektet unders $ø$ kt ledelse som praksis, og siden 2008 har en rekke mastergradsoppgaver om kirkelig ledelse kommet ut av prosjektet. Konkret bygger dette kapitlet på en stor spørreskjemaundersøkelse i 2016, som ble gjort blant proster og kirkeverger i Den norske kirke, samt en noe mindre intervjuundersøkelse (Fiske, 2017; Mjånes, 2017). ${ }^{2}$ I analysen anvender vi en ledelsesmodell som søker å integrere kompleksiteten i lederes rolle, ivaretatt gjennom ulike lederrolleprofiler.

Vi presenterer først kapitlets metodiske forankring i ledelsesfaget, før vi ser nærmere på hvordan problemstillingen henger sammen med folkekirkens kontekst og organisering. Deretter gir vi et riss av den historiske og kirkelige bakgrunn for funksjonen og posisjonen som kirkeverge, og

1 Deler av datamateriale fra samme undersøkelse er også omtalt i kapittel 9 (Sirris \& Askeland), om lederroller og identitet.

2 Se nevnte arbeider for en nærmere gjennomgang av metodisk tilnærming og en bredere analyse. 
bruker dette som bakgrunn for å belyse hvordan og i hvilken grad kirkevergene fremstår med en bevisst institusjonell kirkelederprofil.

\section{En integrert ledelsesmodell}

Ledelsesfaget er mangfoldig og med ulike tradisjoner. Sentrale begreper som tidlig ble brukt i internasjonal ledelseslitteratur var administration og management, mens det fra 1980-tallet av ble stadig mer bruk av begrepet leadership. Fra 1990-tallet har også offentlig virksomhet blitt preget av vekt på bedre organisering, vekt på ledelse og tydelighet i styringsrollen, som tidligere nevnt i kapitlene 4 og 6. Disse reformene omtales som New Public Management (NPM) (Hood, 1991). I kirkelig sammenheng falt behovet for å utvikle lederfunksjoner og ivareta arbeidsgiver- og personalansvar sammen med et nytt vokabular og nye forventninger til å utøve ledelse. Med lederskapsbegrepet kom ideen om visjon, verdier og utvikling for alvor inn i ledelsesdebatten. Den eller de som drev med strategisk og meningsdannende lederskap ble i økende grad tenkt frikoblet fra administrative oppgaver og ansvar.

Grepet i dette kapitlet er å anvende en modell som kombinerer to sentrale dimensjoner: oppgaveorientering versus relasjonsorientering, samt intern versus ekstern orientering (jf. også drøfting i kapitlene 8 og 9). Begrepsmessig anvendes begrepet lederrolle, forstått som summen av de forventninger som knytter seg til lederes posisjon og stilling i organisasjoner (Askeland, 1998). Modellen bygger på to sentrale dimensjoner, henholdsvis oppgave- versus relasjonsorientering samt intern versus ekstern orientering, og skiller dermed analytisk mellom ulike rolleprofiler (jf. tabell 1). Modellen er anvendt i analyser av lokalsamfunnsbaserte organisasjoner innen sivilsamfunnet (Botvar \& Schmidt, 2010; Schmid, 2013), samt av prosters og kirkevergers lederrolle i Den norske kirkes menigheter (Askeland, 2015; Fiske, 2017; Mjånes, 2017; Myrvang, 2020).

Teoretisk representerer dette en videre utvikling av anvendt modell fra tidligere studier av kirkelige lederroller, se også kapittel 9 (Askeland, 1998; Hauken, 2007; Skårberg, 2007; Krogh, 2010). Disse tidligere studier anvendte en modell med en noe annen firedelt lederrolleprofil: produsent, administrator, entreprenør og integrator (Strand, 2007). Mens ekstern 
versus intern orientering er like, representerer orientering mot stabilitet versus endring en noe annen vinkling.

Argumenter for utvikling av en integrert ledelsesmodell har vært knyttet til to viktige aspekter. Harald Askeland (2016) hevder at tidligere studier ikke i tilstrekkelig grad fanget opp religiøst funderte organisasjoner, da de var basert på anvendelse av mer generelle modeller.

I motsetning til næringslivsorganisasjoners effektivitetsforventning der konkurrenter og kunder var sentrale aktører i konteksten, møter religiøst funderte organisasjoner like gjerne krav med hensyn til legitimitet, identitet og verdier i relasjon til aktører i det omkringliggende samfunn. Dermed er rolleprofilen produsent erstattet med mellommann, og rolleprofilen dirigent har overtatt for administrator (men med betydelige likheter). I tillegg har spørsmålet om verdier og identitet vært mindre vektlagt i tradisjonell ledelsesforskning, men har vært artikulert i klassiske bidrag (Barnard, 1938; Selznick, 1957) og blitt tilrettelagt for kirkelig ledelse (Carroll, 2011). Forventningene knytter seg til det oppdrag og formål organisasjonen har i samfunnskonteksten, både i forhold til medlemmer og med hensyn til samarbeidende interesser. Slik ble rolleprofilen institusjonell leder lagt til i modellen. Sentrale dimensjoner ved lederskap inkluderer helhet, mening og verdifokus (jf. tabell 1). ${ }^{3}$ Den institusjonelle dimensjonen ved ledelse innebærer to viktige sider: For det første et overordnet ansvar for at tjenester og oppgaver bidrar til resultatet for organisasjonen (enheten), samtidig som ulike aktiviteter holdes sammen i et koordinert og fungerende hele. For det andre utøver den institusjonelle siden institutional leadership, slik det er blitt formulert av organisasjonsforskerne Barnard (1938) og Selznick (1957). For ledere innebærer dette å bidra til ledelse av meningsdanning, til artikulering av formål og det å fremme verdier generelt og institusjonens kristne verditradisjon spesielt. En første måte å ringe inn den sentrale lederutfordring på for verdibevisst ledelse i folkekirken vil kunne ligge i å reformulere et utsagn om institusjonelt lederskap: "A special concern for the preservation of the Christian identity of the congregation in constantly changing circumstances» 
(reformulert etter Carroll, 1991, s. 97). Denne basale oppgave knyttes så sammen med teorier om institusjonelt lederskap (Selznick, 1957).

I tillegg til den sentrale profilen som institusjonell leder, inkorporerer altså modellen fire ulike profiler for ivaretakelsen av ledelse eller konkrete lederroller: dirigent, integrator, tjenesteutvikler og mellommann. Viktige funksjoner innebærer å klargjøre organisasjonens oppdrag og mål, virkeliggjøre dette formål i organisasjonens liv og virksomhet, samt å bidra til at organisasjonen og dens medlemmer formulerer og fastholder grunnleggende verdier i møte med omgivelsene. Hovedinnholdet for hver enkelt rolleprofil fremgår av tabell 1 (jf. tabell 1 i kapittel 8 for det empiriske grunnlaget for rolleprofilene).

Tabell 1. Sammenfatning av rolleprofilene i kirkelig lederskap

\begin{tabular}{|c|c|c|c|}
\hline \multicolumn{4}{|c|}{ Institusjonell (kirke)leder } \\
\hline \multicolumn{4}{|c|}{$\begin{array}{l}\text { Helhetlig ansvar for fungering og resultat for organisasjon og enheter. Bidra til artikulering } \\
\text { av identitet og oppdrag. Bidra til utvikling av strategi og en helhetlig tilnærming til } \\
\text { menighetsbygging og utvikling. }\end{array}$} \\
\hline Intern - oppgave & Intern - relasjon & Ekstern - oppgave & Ekstern - relasjon \\
\hline Dirigent & Integrator & Tjenesteutvikler & Mellommann \\
\hline $\begin{array}{l}\text { - Fasilitering av } \\
\text { arbeidsprosesser } \\
\text { - Ressursfordeling } \\
\text { - Organisering av } \\
\text { tjenester og rammer } \\
\text { for menighetens og } \\
\text { ulike medarbeideres } \\
\text { tjeneste }\end{array}$ & $\begin{array}{l}\text { - Støtte, inspirere } \\
\text { og veilede } \\
\text { medarbeidere } \\
\text { - Utruste individer og } \\
\text { team til jobbutførelse }\end{array}$ & $\begin{array}{l}\text { Strategisk utvikling } \\
\text { eller tilpasning av } \\
\text { tjenester og tiltak } \\
\text { relatert til forståelse } \\
\text { av forholdet mellom } \\
\text { oppdrag og kontekst }\end{array}$ & $\begin{array}{l}\text { - Samarbeid mellom } \\
\text { ulike enheter } \\
\text { - Bygge relasjoner til } \\
\text { lokalsamfunnet } \\
\text { - Regulere og } \\
\text { forhandle } \\
\text { relasjoner til andre } \\
\text { organisasjoner }\end{array}$ \\
\hline
\end{tabular}

\section{Folkekirken som ledelseskontekst}

Kapitlets forskningsspørsmål dreier seg om hvordan kirkevergens lederrolle har utviklet seg, samt hvordan kirkevergene profilerer seg som lokale kirkeledere. Både dette og vårt tilhørende datagrunnlag er relatert til endring i folkekirkens kontekst og organisering. Når Den norske kirke omtales som folkekirke, har dette ofte noen sentrale kjennetegn: Folkekirken er en kirke hvor dåpen er grunnlag for medlemskap og stemmerett, og omfatter oftest det store flertall av folket. Som en følge av dette er den landsdekkende, med en territoriell inndeling og organisering. 
Den lokale menighet, med lokalsamfunnet som stedlig forankring (Tønnessen, 2014, s. 10), er et sentralt kjennetegn ved folkekirkeforståelsen. Status som statskirke opphørte i 2012 og Den norske kirke ble etablert som et nasjonalt rettssubjekt fra 2017, mens de lokale sokn har vært rettssubjekter siden 1997. Denne selvstendiggjøringen har ledet til et fornyet arbeid med nyorganisering, med en mindre omfattende trossamfunnslov fra 2020 som rettslig fundament. ${ }^{4}$ Samtidig synes det å være en klar forutsetning, både politisk og kirkelig, at folkekirken har demokratiske kjennetegn og at dens tjenester er gratis og allment tilgjengelig. Gjennom Kirkemøtets dokument og Den norske kirkes identitet og oppdrag påpekes det at kirken ikke er identisk med folkefellesskapet, men utgjør et særegent fellesskap i dåp og tro. Slik kobles folkekirkebegrepet til forståelsen av å være et trossamfunn, der denne identiteten gis uttrykk som en «bekjennende, misjonerende, tjenende og åpen folkekirke» (Kirkemøtet, 2004). Disse endringene i institusjonelle rammer, utgjør konteksten for forskningsprosjektet som artikkelen henter data fra.

I tillegg til en slik tilrettelegging av identitet og oppdrag, har kirken gjennom den nye trossamfunnsloven (2020) $\$ 10$ fått klare normative forventninger om at formålet er fortsatt å være en landsdekkende og demokratisk folkekirke. Selv med oppløsningen av statskirken, er Den norske kirke lovhjemlet og med en politisk forventning om tilstedeværelse over hele landet og med en demokratisk forankring og dels til en kontinuerlig prosess med fornying og utvikling av organisasjon og tjenester. Mens trossamfunnsloven $\S_{1}$ (faneparagrafen) kun angir at formålet er å understøtte trossamfunn, gis det fremdeles tydeligere normative forventninger til Den norske kirke som folkekirke.

\section{Kirkevergens kirkehistoriske bakgrunn}

Kirkevergens funksjon som forvalter av viktige deler av kirkens midler og formue har røtter tilbake til middelalderen. Historisk var det en tett kobling til forvaltning av ressurser og av kirkebyggene. Da kirkelige

$4 \quad$ For en grundigere gjennomgang av denne prosessen, se kapittel 3 om drivkrefter i kirkens utvikling (Sirris, Askeland \& Grimstad). Trossamfunnsloven som vil ramme inn fremtidig kirkeordning ble vedtatt i 2020 og trådte i kraft 1. januar 2021. 
inntekter ble overført fra biskopene til lokale menigheter ved kirkeeiere, ble lokal kirkeformue delt i to. Prestebordsgodset (mensa) bidro til underhold av prestetjenesten, mens kirkeformuen og gods (fabrica) var forbeholdt kirkebygg og vedlikehold (Alsvik, 1995).5 Fra 1100-tallet inngikk kirkevergene i den lokale forvaltning som utviklet seg i byene. Funksjonen ble ordnet som ombud, og kirkevergen ble utpekt blant menn med høy sosial status. Oppdraget ble opprinnelig utøvet med et biskoppelig mandat ut fra kanonisk rett. Med de endringer i kirkestyret som fulgte etter reformasjonen, fikk kirkevergene et kongelig lovfestet mandat. Da kirkens medlemmer i soknet fikk egne folkevalgte organer gjennom formannskap og soknestyrer fra 1837, opererte kirkevergene med et lokalsamfunnsmandat fra soknets valgte organer. Denne linjen ble videreført i 1997, da kirkevergestillingen ble daglig leder for kirkelig fellesråd, som representerer soknet på kommunenivå. Forvaltningen av ressurser og bygg har vært en vedvarende kjerne i kirkevergens ansvar og oppgaver.

Samtidig har funksjonen også inkludert tydeligere kirkelige oppgaver. Ved etableringen av «medhjelperinstitusjonen» i 1643, lovfestet i 1687, skulle kirkevergene bistå soknepresten i utøvelsen et åndelig og moralsk tilsyn med kirkens medlemmer (Alsvik, 1995, s. 51). I Christian V lov (2. bok, kap 9) fremgår følgende oppgaver for kirkevergene:

§3: Samles når presten ønsker, gi ham råd i alle spørsmål vedrørende hans ansvarsområde, ved behov bistå og hjelpe ham samt at de skal gi akt på alt som kan hjelpe den tvilrådige og som kan tjene guds ære og hands menighets oppbyggelse

Samtidig hadde kirkevergene på landet et lovfestet ansvar for å bidra til utdeling av midler til trengende. Funksjonen ble slik stående mellom lokalsamfunn og kirkelig øvrighet, med mandat som statlig tjenestemann, men denne sammenkoblede funksjonen opphørte med det store kirkesalget fra 1660-årene. Mange steder opphørte kirkevergefunksjonen etter 1720, men den fortsatte imidlertid i byene, der soknet selv eide kirken eller der ny kirkeeier valgte å tilsette kirkeverge for å føre tilsyn med kirken. Flere har pekt på at kirkevergefunksjonen på mange måter fremstod 
som representant for soknets kirkemedlemmer i møte med offentlig og kirkelig øvrighet, og slik på flere måter representerte forløpere for lokaldemokratiske organer (Bjerkås, 2017; Kümin, 2004).

Utover på 180o-tallet, og særlig etter formannskapslovene av 1837, ble kirkevergen oppnevnt av kommunale organer. Dette hang sammen med at de nye kommunene bygde på prestegjeldene og tilhørende sokn, med formannskap og soknestyre. Disse organene overtok skatteretten for vedlikehold av soknekirkene og kirkegårdene som i lov ble lagt til soknene i 1818. En ekspansjon i kirkevergenes oppgaver kom i hovedsak i byene utover 1800 -tallet, og ytterligere etter kirkeloven av 1897. Særlig kom ansvaret for kirkegårdene til å bety en utvidelse av både økonomisk og personalmessig ansvar. Da ansvaret for å finansiere oppgaver med kirkebygg og kirkegårder ble lagt til kommunene, kom utviklingen av stillingen i høy grad til å følge utviklingen av kommuneorganisasjonen som politisk og organisatorisk størrelse. Når ekspansjonen kom i byene hang det sammen med omfanget av oppgavene. Man trengte rett og slett noen som holdt dette sammen og koordinerte på tvers av kommunens sokn med hensyn til kirker og kirkegårder. Rollen som representant for lokalsamfunnet ble også endret, med etableringen av Kirkens tilsyn ${ }^{6}$ som innstilte på oppnevning av kirkeverge samt innstilte forslag for kommunestyret angående budsjett og behov for nybygg.

Som valgte ombud, og etter hvert med større og mindre stillinger, var ansvar og oppgaver konkret knyttet til kirkens materielle struktur. Den indirekte innflytelsen må likevel ha vært til stede, da kirkebygget og kirkegårdene representerte de «arenaer» der folkekirkens liv, virksomhet og ritualer skjedde. Vedtaket om oppretting av menighetsråd i 1920 etablerte et lokalt kirkelig selvstyre, en kirkelig variant av det kommunale selvstyret, men med begrenset mandat. I tillegg til å fremme det kristelige liv i menigheten, overtok rådet kirketilsynets oppgaver av økonomisk og administrativ art. For å ivareta koordineringen overfor kommunen åpnet loven for etablering av kirkelig fellesråd, der kirker og kirkegårder ble

6 Kirkens tilsyn ble valgt i soknet, men hadde oppgaver som var parallelle med de senere kirkelige fellesråd. De kan dermed primært sees som forløpere for menighetsrådene, men også for ordningen med å etablere kirkelig fellesråd der det var flere kirker i kommunen, eller der flere sokn eide kirke sammen. 
underlagt et felles tilsyn. Oppfølgingen av bygg og økonomi, samt menighetsrådenes og fellesrådets behov for saksbehandling, førte til utbygging av kirkevergestillinger som sekretariat for rådene og bindeledd mellom kirke og kommune. Samtidig var kirkevergene tilsatt av kommunen, og den kommunale forvaltningsutvikling medførte at kirkevergene opererte på delegasjon fra rådmannen mens de i utøvelsen av sine oppgaver var underlagt menighetsråd og fellesråd (Raustøl, 1993). Utviklingen medførte at stillingene i økende grad fikk tillagt økonomisk og personalmessig ansvar, særlig knyttet til kirke og kirkegård, men også for øvrige stillinger i menighetene. I forkant av kirkeloven, som ble vedtatt i 1996, var det etablert fellesråd og kirkevergestilling i noe over 200 kommuner.

Posisjonen i skjæringspunktet mellom kirke og kommune ble igjen endret i 1997, da kirkevergen gikk fra å være en kommunal til en kirkelig stilling. Lovfestingen av fellesrådets ansvar og pålegget om å ha en daglig leder for å ivareta oppgaver og funksjoner i det daglige, tydeliggjorde stillingens kirkelige forankring og ansvar. Samtidig innebar dette grepet en klar endring og utvidelse av det tradisjonelle ansvaret.

Fra 1970-tallet begynte soknet og menighetene å få stadig større staber, dels gjennom administrative og praktiske stillinger og dels gjennom en gradvis vekst i stillinger som kantor, kateket og diakon samt en rekke andre menighetsrelaterte stillinger. Forventningene frem mot midten av 1980-tallet var at det hovedsakelig kun trengtes administrativ hjelp for menighetsrådene og til avlastning for sokneprestene. Det man så for seg var en kombinasjonsordning der menighetssekretærene og sokneprestene kunne ivareta disse behovene.? Da kirkelovutvalget under ledelse av biskop Georg Hille la frem sin innstilling i 1989 (NOU 1989: 7), ble tidligere og nytt ansvarsområde lagt sammen: sekretariat, budsjett og arbeidsgiveransvar, men man brukte i hovedsak betegnelsen «overordnet administrativt ansvar» (administrative lederoppgaver). Som et ledd i forslaget om etablering av denne stillingen foreslo utvalget et krav om toårig utdanning med hovedvekt på økonomisk/administrative fag og

7 Ikke minst var menighetsseminarene et utdanningstilbud som reflekterte en slik tenkning, og tilsvarende var sokneprestkursene som ble etablert på 1980-tallet en første lederutdanning for denne gruppen. 
kristendomskunnskap (NOU 1989: 7, s. 163). ${ }^{8}$ Dette ble også begrunnet med ekspansjon i oppgaver, men særlig viktig var overføringen av arbeidsgiveransvaret til soknet (ved MR og FR). Samtidig la utvalget avgjørende vekt på soknets stilling og menighetsrådet som det sentrale lokale kirkelige styringsorgan. Derfor foreslo utvalget at stillingen som kirkeverge skulle etableres på soknenivå, og at den skulle ivareta lederfunksjonen. Den omfattende høringsrunden la denne løsningen død, da kun få instanser ønsket å legge et så omfattende ansvar til soknet. Departementets lovforslag, og Stortingets vedtak, fulgte derfor opp en klar tilbakemelding fra både kirkelige organer og også fra kommunene ved å lovfeste fellesråd og stilling som daglig leder (kirkeverge) på kommunenivå.

Gjennomgangen av den historiske bakgrunn viser noen sentrale trekk ved kirkevergen som ombud og stilling. Den vokste frem ut fra et kirkelig behov for forvaltning av økonomiske og materielle ressurser, samt et behov for et overordnet ansvar for de som utøvet arbeidet med kirker og kirkegårder. Den kirkelige forankring har vært permanent, men skiftende under det som til enhver tid har vært naturlig kirkelig myndighet. Rollen har hatt sin primære forankring i lokalsamfunnet, dels som representant for og dels overfor soknets innbyggere. Da soknet ble selvstendiggjort gjennom kirkeloven av 1996, skjedde en redefinering og utvidelse av ansvarsfeltet mot en tydelig lederstilling. Med sine nye ansvarsområder trengte soknets organer et sekretariat og en daglig leder som var ansatt av og sto ansvarlig overfor kirkelig fellesråd. Slik skulle stillingen også ivareta koordinering mellom soknene og i forhold til kommunen. Denne omdreiningen i rollens forankring og ansvarsområde, men fremdeles i skjæringspunktet mellom kirkelige og lokalsamfunnsorganer, aktualiserer interessen for hvordan kirkevergestillingene blir profilert og hvilken lederidentitet som utvikles.

8 Med utgangspunkt i dette forslaget, ble det opprettet et toårig kirkevergestudium ved Høgskulen i Volda i 1995 og en tilsvarende utdanning i kirkelig administrasjon ved Diakonhjemmet høyskole i 1996. 


\section{Presentasjon og drøfting av sentrale funn}

I det følgende presenterer vi funnene fra tidligere studier av kirkevergens lederrolle, fra lovfestingen i 1997 og frem til overgangen til ny kirkeordning i 2017.

En studie fra den første perioden etter ny kirkelov i 1997 (Askeland, 1998), bygde på en nærliggende men ikke identisk ledermodell. Følgende roller ble anvendt: produsent, administrator, entreprenør og integrator. ${ }^{9}$ Funn fra studien viste at kirkeverger vektla integratorrollen som viktigst av alle lederkategoriene, entreprenørrollen var den neste mens produsentrollen ble vektlagt på tredje plass. Når det gjaldt omfang av tidsbruk til de samme rollene, ble noe av tendensen videreført. Mange kirkeverger oppga at de også brukte svært mye tid på integratorrollen, og fremsto også som den kategorien ledere som brukte mest tid på produsent- og administratorrollen. Særlig sokneprestene oppga å bruke lite tid på disse rollene. En slik profil indikerer at kirkevergenes stilling var forankret i en forståelse av at lederrollen ivaretas i og overfor den lokale kirke som organisasjon. Kirkevergene profilerte seg på stabilitetsorientering, både internt og eksternt.

I 1997 ble det antatt at entreprenørrollen var lavt prioritert grunnet en betydelig administrativ belastning med etablering av styringsstrukturer og prosedyrer i forbindelse med overtakelse av arbeidsgiveransvar fra kommunene. Trosopplæringsreformen fra 2004, med en klar lokal forankring av ansvar og ressurstildeling, synes å ha vært medvirkende årsak til at kirkevergene over tid utviklet sin lederrolleprofil mer i retning av utadrettet menighetsvirksomhet, noe som dermed styrket entreprenørrollen.

To tiår senere ble det rapportert om klare endringer (Mjånes, 2017). For det første profilerte proster og kirkeverger egen lederrolle nokså likt, med hensyn til både forventninger og reell angitt tidsbruk, for rollene som institusjonell leder, dirigent og integrator. Ut fra tidligere studier er det grunn til å anta at disse funksjonene representerer det ledere brukte

9 Sammenheng og overgang mellom Strands modell (Strand, 2007) og den integrerte modellen vi anvender her (Askeland, 2016), er omtalt i kapittel 9. 
mesteparten av sin tid på, noe som innebærer antakelse om at kirkelige ledere utøver en ledelsespraksis som er nokså lik i det daglige. I praksis innebærer en slik rolleprofilering at proster og kirkeverger anvender mye av tid til organisering og koordinering knyttet til daglig drift av kirkelig virksomhet, og at de i stor grad vektlegger relasjoner og samhandling med medarbeidere. Sett over tid innebærer dette en markert endring fra 1997, der kirkeverger skilte seg ut ved en større vekt på produsent- og administratorrollen. De mest markerte forskjellene i materialet finner vi i rollene som tjenesteutviklere og mellommenn, der kirkevergene signaliserte en markert endring i rollen som tjenesteutvikler, mens de scoret betydelig lavere på anvendt tid til entreprenørollen i 1997. Rollen som mellommann er ny i forhold til tidligere studier, men enkeltfunn i tidligere studier støtter opp om den tendensen som ses i analysen av årets datamateriale. Fra Lederrolleundersøkelsen i 1997 vet vi at kirkevergene oppga et hyppig kontaktmønster både mot prestetjenesten og rådsleder samt til kommunale organer og samarbeidspartnere. Dette kan leses som en indikasjon på at nettverk, og ikke minst ressursakkvisisjon, var sentrale aspekter ved rollen også den gang.

Tabell 2. Prosters og kirkevergers samlede profilering av lederroller, basert på forventning fra overordnede og tidsbruk på rollene på en skala fra 1-5, der 1 er lavest og 5 høyest forventning og tidsbruk (Mjånes, 2017, s. 46-51)

\begin{tabular}{lccccc}
\hline \multicolumn{5}{c}{ Forventninger fra overordnet organ } \\
\hline & Inst. leder & Tjenesteutvikler & Dirigent & Integrator & Mellommann \\
\hline Kirkeverge & 4,0 & 3,9 & 4,3 & 4,3 & 4,1 \\
Prost & 4,1 & 3,5 & 4,0 & 4,3 & 3,6 \\
\hline \multicolumn{5}{c}{ Rapportert tidsbruk } \\
\hline \multirow{7}{*}{ Kirkeverge } & Inst. leder & Tjenesteutvikler & Dirigent & Integrator & Mellommann \\
\hline Prost & 3,6 & 3,7 & 4,0 & 4,1 & 3,7 \\
\hline
\end{tabular}

Samtidig viser analysen at kirkevergene skilte seg noe fra proster i profilen som institusjonell leder. De opplevde tydeligere forventninger til det å prioritere virksomhetens samlede resultater, mens prostene i større grad opplever forventninger om å bidra til å sette verdier og etisk bevissthet på dagsorden. Også for rollen som tjenesteutvikler opplever kirkevergene tydeligere forventninger om tilpasse virksomheten til 
endrede rammer og det å skape forståelse for organisasjonens virke med sikte på å sikre ressursgrunnlaget. Dette reflekterer denne gruppens sentrale funksjon på vegne av lokalkirken i relasjon til kommunene som tilskuddsyter. Kirkevergene forventes å skape forståelse utad for virksomhetens behov samt å bidra til informasjon om organisasjonen i møte med eksterne aktører. Når det kommer til tidsbruk oppgir de forskjell på flere av rolleprofilene som svarer til forventningene. Også her er det slik at kirkeverger oppgir å bruke mer tid på utvikling av virksomheten samt på relasjonsbygging til lokalsamfunnsaktører. Selv om studien neppe avdekker forskjeller i generell tidsbruk, angir dette en opplevd prioritering av og medgått tid.

Studiene til Mjånes og Fiske viser at kirkevergene i stor grad opplever å ha legitimitet som lokale kirkeledere. Det har også skjedd en utvikling der kirkeverger forventes å bidra til en helhetlig tilnærming som knyttes til institusjonelt lederskap, blant annet med vekt på styring av det utviklingsorienterte arbeidet. Slik dokumenterer Mjånes sin studie også en videreutvikling av entreprenørskap innen rolleprofilen tjenesteutvikler. Selv med viktige funn knyttet til likedanning mellom lederrollene til kirkeverge og prost, finner hun at kirkeverger møtes av tydelige forventninger om å være dirigent.

Mjånes finner også at kirkevergene oppgir å ha en rimelig balanse mellom ansvar og myndighet, der de i stor grad opplever å være delegert ansvar og gitt et handlingsrom for å utøve jobben som daglig leder. Ut fra materialet peker hun på at det kan se ut som om kirkevergene styrker sin legitimitet som kirkelige ledere.

Fiske (2017) reiser spørsmålet om på hvilken måte kirkevergens lederrolle har utviklet seg i Den norske kirke gjennom de siste tjue årene. Studien, som omfatter kirkeverger med lang stillingserfaring, finner at kirkevergene er opptatt av sin rolle som kirkelige ledere i den lokale kirken. Som ledere identifiserer og beskriver de seg som bidragsytere og pådrivere til at menighetslivet skal utvikle og fornye seg. Studien konkluderte med at kirkevergene er viktige ledere i den lokale kirken. Som ledere gir de uttrykk for et stort engasjement for kirken og dens oppdrag, og mener selv å bidra til at kirkens verdier og visjoner får blomstre i menighetene. 
Hva er så viktige elementer i måten kirkevergene forstår sin lederrolle? Informantene i undersøkelsen var opptatte av at de var kirkelige ledere som hadde et helhetlig ansvar i å være aktører i å bygge menigheter i Den norske kirke. For noen av informantene var dette årsaken til at de har valgt å arbeide i kirken. Datamaterialet viser at kirkevergene ønsket å finne gode løsninger på det daglige arbeidet i menighetene, samt at de ansatte skulle ha meningsfylte arbeidsdager slik at de var i stand til å utføre sine arbeidsoppgaver på beste måte.

I materialet oppviser de også en refleksjon over at disse mer overordnede sidene ses i sammenheng med andre sider ved lederjobben, slik et typisk utsagn viser: «Ledelsen handler da [...] på en måte [om] å gi retning om hvor en skal. Og så er administrasjon å følge opp i praksis ved å gå ved siden av - gå sammen med» (Fiske, 2017, s. 44). I ett og samme sitat pekes det dermed på både retning, administrativ oppfølging og relasjonelle aspekter ved ledelse. Det er grunnlag for å si at informantene i denne undersøkelsen hadde en gjennomgående nøktern og integrert forståelse av lederjobben.

Et viktig funn i studien handlet om utvikling av rollen i relasjon til øvrige ledende roller. Samhandling med ansatte, fellesrådet, menighetsrådet og prostene ble opplevd som preget av god interaksjon. Arbeidsgiverrollen i rådslinjen har utviklet seg til å bli et godt etablert forhold mellom arbeidsgiver og arbeidstakerne. Kirkevergene opplevde at deres rolle har oppnådd tillit, og ansatte er trygge på hvem som er sin nærmeste overordnede. Samtidig skiller ansatte mellom funksjoner, og var svært bevisste på at forrettende prest var leder i forbindelse med kirkelige handlinger. Forutsigbare arbeidsvilkår bidrar til gode samhandlinger og godt arbeidsmiljø.

Særlig ble forholdet mellom kirkevergerollen og rådene beskrevet som godt. Datamaterialet i studien viste at det var god samhandling mellom rådene i kommunen. Hensikten med å etablere et fellesråd med en daglig leder for virksomheten var å utføre oppgaver på vegne av menighetene. Informantene gav uttrykk for at det var etablert et tillitsforhold, hvor det er en gjensidig oppfatning av at kjernen i all virksomhet handler om å bygge menigheter. I denne sammenheng kan en si at kirkevergerollen har bidratt med en institusjonell ledelse, hvor ulike behov i organisasjonen er ivaretatt i samhandling med rådene. 
Også når det gjaldt samhandlingen med prestelinjen ble det gitt uttrykk for at den fungerer godt på menighetsnivå, noe som tyder på at ansatte $\mathrm{i}$ rådslinjen og prestetjenesten samarbeider bevisst ut fra egne roller og hvert sitt selvstendige ansvar. Samtidig var det slik at forholdet mellom prostetjenesten og kirkevergerollen fungerte forskjellig. Noen steder var det gode møteplasser hvor en samarbeidet og avklarte ulike forhold, mens andre erfarte mangel på slike møtepunkter. Det kom frem i datamaterialet at kirkevergene også hadde møtt motstand med hensyn til forståelsen av rollen som virksomhetsleder i den lokale kirken. Det synes å ta tid å få etablert en ny lederstilling med et klart mandat i en organisasjon, som tradisjonelt har hatt en svakere ledelsesorientering.

Stillingene som virksomhetsledere i Den norske kirke ble lovbestemt gjennom kirkeloven av 1997, og mange av kirkevergene gav uttrykk for at de var nye i sin posisjon som ledere. De var gjennom loven og tilsettingen gitt et mandat til å være ledere i sine lokale kirker, og skulle mellom annet ivareta arbeidsgiveransvaret og bidra i å styrke kvaliteten i forvaltningsarbeidet i forhold til et definert ansvarsområde. Ved lovens nyorientering ble denne stillingen en lederstilling som skulle samhandle med ansatte i fellesrådet, menighetsråd og prestetjenesten. Informantene opplevde at deres hovedoppgave var å bidra til at menighetsrådene skulle oppfylle sitt oppdrag, slik den var definert i daværende kirkelovs $₫ 9$ og videreført i ny kirkeordning $\$ 12$, på en mest mulig profesjonell måte. Dette ansvaret skulle realiseres ved at kirkevergerollen hadde det daglige arbeidet med å være arbeidsgiver og ha ansvaret for økonomien samt for vedlikehold av kirkebygg på vegne av rådene i den lokale kirken. Datamaterialet peker mot at kirkevergenes rolleforståelse oppviste en lederidentitet som ligger nær rollen som institusjonelle ledere i Den norske kirke.

I forskningsprosjektet kom det frem at kirkevergerollen ble opplevd anerkjent som arbeidsgiver og som daglig leder for ansatte i fellesrådet. Kirkevergene erfarte at de gjennom sin ledelsesutøvelse har skapt tillit mellom arbeidsgiver og ansatte. De opplever selv at ansatte har klare forventninger til at arbeidsplassen skal fungere med tanke på arbeidstid, lønnsutbetalinger, arbeidsverktøy med mer. Menighetsråd sies å ha forventninger til at kirkevergene utfører de forvaltningsoppgavene som er fellesrådets ansvarsområder. 
Informantene var tydelige på at de står for kirkens oppdrag, at de identifiserer seg med virksomheten og at de gjør en tjeneste i Den norske kirke som trossamfunn. En av informantene formulerer seg slik i relasjon til oppdragsforståelse:

Og så er det at jeg har blitt mer og mer bevisst på at det er en kirkelig lederstilling. Det er en del av kirkens arbeid, og jeg mener at kirkens oppgave er å formidle evangeliet gjennom forkynnelse, gjennom trosopplæring og gjennom diakoni ... (Fiske, 2017, s. 46)

Informantenes responser i studien må fortolkes slik at de erfarer å ha legitimitet som institusjonelle ledere. De erfarte at de samhandler godt både med ansatte og prestelinjen. De gav uttrykk for at samhandling var en dialog, som kunne skape gjensidig tillitt. Selv om de registrerte at det kunne være diskusjoner om rollen i media og i en større kirkelig diskusjon, gav informantene uttrykk for at de erfarte at de som enkeltindivid ble møtt med respekt i sammenhenger både lokalt, regionalt og på sentralt nivå. Kirkevergerollen har fungert i sin nye form som lederstilling lokal i tjue år og det er etablert tradisjoner som er knyttet til lederstillingen. Med grunnlag i studien er det et hovedinntrykk at kirkevergen erfarte at deres posisjon i samfunnet var respektert og at de ble oppfattet som ledere både i arbeidsgiverrollen og i samarbeid med prestetjenesten lokalt. Imidlertid opplever enkelte at dette har tatt noe tid, slik to svar indikerer:

[J]eg føler på mange måter at det har vært en kamp da for [å] ha fått det dit vi er kommet nå med den samhandlingen. For det er klart at de - at kirkevergen skal være en anerkjent stilling i Den norske kirke det er det jo ... Det var nå en vei å gå det [...] til å begynne med. Så jeg tror nå at kirkevergen har jobba for å komme dit de er i dag.

$[\ldots]$

Ja, jeg tror det er det tydeligste - at vi er blitt mer ledere - tas med. Slipper å kjempe seg inn. Slipper å ta kirkevergerollen. (Fiske, 2017, s. 59)

Gjennom en felles virkelighetsoppfatning av den tidligere kirkeloven, og videreført i ny kirkeordning, har alle i den lokale kirken, slik som ansatte, 
menighetsråd og fellesråd, bidratt til at kirkevergerollen i dag er gitt legitimitet som virksomhetsledere i Den norske kirke.

\section{Konklusjon}

Modellen som er anvendt i dette kapitlet kombinerer to sentrale anliggender innen ledelsesforskning. For det første bygger den på en forutsetning om at ledere ivaretar generelle oppgaver og funksjoner på vegne av og for organisasjonen. For det andre bygger den på at ledelse handler om ansvar for helhet og resultat, basert i et mandat fra organisasjonen og dens styringsorganer. Til dette helhetlige ansvar hører også å tolke virksomheten og arbeidet innen rammen av et overordnet formål og i lys av grunnleggende verdier.

I våre funn fremstår kirkevergene mer helhetlige i sin lederprofilering enn det som ble rapportert like etter at tidligere kirkelov trådte i kraft i 1997. Særlig har de utviklet rolleprofilen knyttet til utvikling og tilpasning av kirkens tjenester, omtalt som tjenesteutvikler. De uttrykker også en orientering mot helhet, verdier og koordinering av ulike bidrag innen organisasjonen. Slik vi tolker det materialet som er presentert innebærer dette at kirkevergene har en tydelig lederidentitet som svarer til den lederrollen de ivaretar.

Samtidig kommer det også frem at kirkevergene har en tydelig kirkelig identitet som svarer til det legale rammeverk som legitimerer stillingene. Slik reflekterer også lederidentiteten at de forholder seg til et kirkelig mandat, gitt av det organ representerer soknet som de aktuelle kirkelige enheter. Dette har imidlertid tatt noe tid, og i Fiske sin studie gir flere informanter uttrykk for at dette er noe som har endret seg over tid. Tilpasning har tatt tid, og stedvis møtt både personlig og ikke minst strukturell motstand. Kirkevergene opplever større grad av aksept fra lokal prest og prost enn fra regionale og sentrale kirkelige organer.

Et siste viktig funn er at kirkevergene ivaretar en lederrolle som er tilpasset folkekirken som kontekst, gjennom å ha en tilnærming til å bygge relasjonelt samarbeid mellom råd og mot lokalsamfunnsorganer - i særlig grad kommunens bevilgende organer. Dette bekreftes i en nylig studie som undersøker fem kirkevergers profilering som tjenesteutviklere 
(Myrvang, 2020). Kirkevergene bidrar til å initiere og fremme samskaping med kommunale instanser, noe som også leder til at menighetene får tilskudd til kirkelige stillinger og tiltak som understøtter lokalsamfunnets definerte behov.

\section{Referanser}

Alsvik, O. (1995). Fra ombud til «kirkens rådmann»: Historisk del. I S. Sjølie, H. Håvarstein \& M. Klafstad (Red.), Fra ombud til «kirkens rådmann»: Kirkeverger gjennom 800 år. Verbum.

Askeland, H. (1998). Ledere og lederroller: Om ledelse og lederroller i den lokale kirke. Tapir.

Askeland, H. (2015). Reforming the pastoral leadership structure in Church of Norway: Exploring whether and how the managerial role of the dean has been strengthened. I H. Askeland \& U. Schmidt (Red.), Church reform and leadership of change (s. 92-116). Pickwick Publications.

Askeland, H. (2016). Ledelse og lederes rolle i Den norske kirke: Lederrolleundersøkelsen 2016 i et tyveårsperspektiv. Tidsskrift for Praktisk Teologi, 33(2), 5-19. https://journals.mf.no/tpt/article/view/5197

Barnard, C. (1938). The functions of the executive. Harvard University Press.

Bjerkås, T. (2017). From the parish to the public realm: Changing terms of local government in Norway between absolutism and constitutional rule. Scandinavian Journal of History, 42(5), 477-504. https://doi.org/10.1080/03468755.2017.1381388

Botvar, P. K. \& Schmidt, U. (Red.). (2010). Religion i dagens Norge: Mellom sekularisering og sakralisering. Universitetsforlaget.

Carroll, J. W. (2011). As one with authority: Reflective leadership in ministry. Wipf and Stock Publishers.

Fiske, M. (2017). Det er en kirkelig leder jeg er. Hvordan og på hvilken måte har kirkevergens lederrolle i Den norske kirke utviklet seg gjennom de siste tjue årene? [Mastergradsoppgave, VID vitenskapelige høgskole]. VID Open. http://hdl. handle.net/11250/2452812

Frank, T. E. (2006). Leadership and administration: An emerging field in practical theology. International Journal of Practical Theology, 10(1), 113-136. https://doi.org/ 10.1515/IJPT.2006.009

Haug, H. (2016). Transformasjonsledelse og innovasjon i Den norske kirke [Mastergradsoppgave, VID vitenskapelige høgskole]. VID Open. https://hdl. handle.net/11250/2675655

Hauken, Ø. (2007). Todelt ledelse i den lokale kirke [Mastergradsoppgave, Diakonhjemmet Høgskole]. NILU Brage. https://core.ac.uk/reader/52042523 
Hood, C. (1991). A public management for all seasons? Public Administration, 69(1), 3-19. https://doi.org/10.1111/j.1467-9299.1991.tboo779.x

Jenssen, J. I. (2018). Leadership and church identity. Scandinavian Journal of Leadership and Theology, 5. https://sjlt-journal.com/no5/leadership-and-churchidentity/

Kirkerådet. (2004). Den norske kirkes identitet og oppdrag. Uttalelse fra Kirkemøtet 2004. Den norske kirke. https://kirken.no/globalassets/kirken.no/om-kirken/slikstyres-kirken/planer-visjonsdokument-og-strategier/identitet_oppdrag_2004_ bokmaal.pdf

Krogh, A. H. (2010). Det som ikke skjer lokalt, skjer ikke. Om ledelse og lederroller på lokalplanet $i$ Den norske kirke [Mastergradsoppgave, Diakonhjemmet Høgskole]. VID Open. http://hdl.handle.net/11250/98421

Kümin, B. (2004). Late medieval churchwardens' accounts and parish government: Looking beyond London and Bristol. The English Historical Review, 119(480), 87-99. http://dx.doi.org/10.1093/ehr/119.480.87

Mjånes, Å. S. (2017). Kvar er seg sjølv noerast. Eit kvantitativt studie av prostar og kyrkeverjer sine leiarroller og legitimitet i Den norske kyrkja [Mastergradsoppgave, VID vitenskapelige høgskole]. VID Open. http://hdl.handle.net/11250/2452752

Myrvang, R. E. L. (2020). Kirkeverge som lokal kirkestrateg [Mastergradsoppgave]. VID vitenskapelige høgskole.

NOU 1989: 7. (1989). Den lokale kirkes ordning. Oslo: Kirke- og undervisningsdepartementet. https://lovdata.no/pro/forarbeid/nou-1989-7

Raustøl, T. (1993). Kirkelig selvstyre - $i$ kommunen? Oppfølgning av Kirkelovutvalget $i$ spenningsfeltet mellom kommunalt og kirkelig selvstyre. Kommuneforlaget.

Schmid, H. (2013). Nonprofit human services: Between identity blurring and adaptation to changing environments. Administration in Social Work, 37(3), 242-256. https://doi.org/10.1080/03643107.2012.676611

Selznick, P. (1957). Leadership in administration: A sociological interpretation. Row Peterson.

Sirris, S. (2016). Arbeidsdager mellom profesjon, ledelse og organisasjon. Soknepresters tidsbruk og aktivitetsmønstre. Teologisk Tidsskrift, 5(1), 60-94. https://doi.org/1018261/ISSN.1893-0271-2016-01-05

Skårberg, B. (2007). «Der linjene møtes». Prost og kirkeverge om enhetlig ledelse i den lokale kirke [Mastergradsoppgave, VID vitenskapelige høgskole]. VID Open. http://hdl.handle.net/11250/98407

Trossamfunnsloven. (2020). Lov om tros- og livssynssamfunn (LOV-2020-04-24-31). Lovdata. https://lovdata.no/lov/2020-04-24-31

Tønnessen, A. V. (2014). Grunnlovens ekklesiologi - en tolkning av den nye $₫ 16 \mathrm{i}$ historisk perspektiv. Tidsskrift for Praktisk Teologi, 31(2), 3-11. https://journals. mf.no/tpt/article/view/5157 



\title{
KAPITTEL 11
}

\section{Personalkonflikter i kirkens arbeidsmiljø som en ledelsesutfordring}

\author{
Stephen Sirris
}

VID vitenskapelige høgskole

\section{Frank Grimstad}

VID vitenskapelige høgskole

\begin{abstract}
The perception that conflicts are unavoidable and natural derives from paradoxical developments in modern work life, with increasing cooperation, democratization, and individual specialization. This chapter asks: How have workplace conflicts been conceptualized and managed within the Church of Norway in the period 1980-2020? We identify three connected concepts key to conflicts: prevention, understanding, and management. These have been adopted from the general literature and applied in the church context. We analyse how conflicts relate to structural and cultural features within the church. From being implicit and largely left to the involved parties, we describe and discuss implications of how conflicts have become a managerial responsibility, in accordance with the Work Environment Law.
\end{abstract}

Keywords: church, conflict, leaders, management, work environment

\section{Introduksjon}

Dette kapitlet tar for seg personalkonflikter i Den norske kirke. Ved å gjennomgå litteratur fra kurs for kirkeledere undersøker vi følgende problemstilling: Hvordan er konflikter $i$ Den norske kirke tematisert $i$ perioden 1980-2020, og hvilke ledelsesutfordringer gir konflikter $i$ et kirkelig

Sitering av denne artikkelen: Sirris, S. \& Grimstad, F. (2021). Personalkonflikter i kirkens arbeidsmiljø som en ledelsesutfordring. I S. Sirris \& H. Askeland (Red.), Kirkelig organisering og ledelse: Et verdibasert og praksisorientert perspektiv (Kap. 11, s. 243-266). Cappelen Damm Akademisk. https://doi.org/10.23865/ noasp.129.ch11

Lisens: CC BY-NC-ND 4.0 
arbeidsmiljø? Denne tidsperioden er viktig for Den norske kirke hva gjelder overgangen fra statskirke til fristilt folkekirke. Det har også foregått en økt profesjonalisering av arbeidsgiveransvaret, som vi kan anta har gitt en utvikling også i konfliktforståelse og syn på forebygging og håndtering av konflikter. Kapitlets bidrag er for det første å sortere i et lite enhetlig kunnskapsfelt ved å definere konfliktbegrepet og identifisere de tre perspektivene konfliktforståelse, konfliktforebygging og konflikthåndtering. For det andre gir kapitlet en kronologisk oversikt med ulike faser hvor vi analyserer hvordan kirken har tematisert konflikter. For det tredje drøfter kapitlet på grunnlag av utvalgte undersøkelser kulturelle og strukturelle trekk ved konflikter i kirkens arbeidsmiljø.

\section{Hva er konflikter?}

Det latinske verbet confligere betyr å støte sammen. En konflikt kan beskrives som en kollisjon mellom interesser, verdier eller handlinger. Sammenstøtet er prosessuelt fremfor punktuelt. En person er i konflikt når vedkommende opplever seg forhindret av andre i å nå mål. Konflikterkjennelse bunner i en parts opplevelse av konflikt. I konflikter blir atferd negativt vurdert, forekommer med en viss frekvens og skaper negative følelser som blir husket. Respekt brytes ned og partene behandler hverandre som objekter. Atferden er klart avvikende fra det man forventer i en god relasjon. Psykologen Tor-Johan Ekelands Konflikt og konfliktforståelse utkom første gang i 2004 og har vært sentralt pensum i kursing av kirkeledere. Ifølge Ekeland (2014, s. 88) krever en situasjon særskilte forutsetninger for å omtales som en konflikt:

Vi kan snakke om konflikt når forskjeller mellom mennesker som er avhengige av hverandre, oppleves som uforenelige og truende i forhold til egne behov og interesser, og når det skapes spenninger og følelser fordi en av partene opplever at den andre benytter makt for å påvirke situasjonen til sin fordel.

Allment kan styrket konfliktpotensial i nyere arbeidsliv relateres til to parallelle utviklinger (Ekeland, 2014). På den ene siden ser vi mer samarbeid, tverrfaglighet og tea marbeid, og på den andre siden økende individualisering og spesialisering. Disse utviklingstrendene utfordrer kollektive 
og individuelle hensyn, siden arbeidslivet består av ulike relasjoner der vi formes som mennesker. Økt omstillingstempo og fleksibilitet utfordrer jobbrelasjonene. Vi kommer inn i arbeidslivet med ulik bakgrunn og oppveksterfaring. Samarbeid læres gjennom trening i å håndtere uenigheter og motsetninger. Hvor det er samarbeid, står partene i et gjensidig avhengighetsforhold. Samarbeid eller konflikt er to mulige utfall av jobbrelasjoner. Disse strukturelle og kulturelle utviklingstrekkene i arbeidslivet, inkludert i kirken, tydeliggjør behovet for at ledere forholder seg til konflikter. Ifølge konfliktforskerne Ståle Einarsen og Harald Pedersen (2017) opptar konflikter $20 \%$ av lederes arbeidstid. Dysfunksjonelle konflikter begrenser produksjonsevne og kreativitet, har negativ påvirkning på helsen og hindrer personlig utvikling.

Mangeårig direktør i KA Kirkelig arbeidsgiver- og interesseorganisasjon (KA), Frank Grimstad, ga i 2002 ut artikkelsamlingen Konflikter $i$ kirken. Om håndtering, forståelse og forebygging av konflikter (Grimstad, 2002). Boken behandler tre temaer som vi vektlegger i dette delkapitlet: konfliktforståelse, konflikthåndtering og konfliktforebygging. Grimstad begrunnet utgivelsen slik (2002, s. 3):

Konflikt er et ord som mange forbinder med Den norske kirke. Konflikt om teologiske og etiske spørsmål, men også samarbeidskonflikter. Meldinger om kirker som stenges forteller om konsekvenser også for tredjepart, menigheten. Arbeidsrettssaker knyttet til samarbeidsforhold i kirken er også svært godt [medie]stoff.

\section{Konfliktforståelse}

Det første hovedtemaet hos Grimstad (2002) er konfliktforståelse, da særlig med vekt på konflikttyper, strukturer som forståelsesramme, teologiens plass i konflikter, juss og organisasjonsteoretiske perspektiver. Arbeidslivsforskerne Bjørg Aase Sørensen og Asbjørn Grimsmo (2001) skiller mellom «varme» og «kalde» konflikter i arbeidslivet. Med kalde konflikter menes motsetninger som oppstår mellom leder og ansatt eller ansatte imellom når det gjelder lønn, arbeidstid og pensjonsordninger. Slike konflikter handler om verdier og prinsipper for fordeling av goder som påvirker en hel gruppes posisjon eller rettigheter. De kalde 
konfliktene er regulert gjennom regler og normer. Det kan også handle om individuelle rettigheter og ansettelsesvilkår. De kan gi høy temperatur, men berører sjelden selvbildet. De varme konfliktene har en annen karakter. Her dreier det seg nettopp om motsetningsforhold som utløser følelser og oppleves truende mot eget selvbilde. Kalde konflikter kan bli varme, eksempelvis i lokale lønnsforhandlinger der arbeidstakere ikke føler seg verdsatt.

Et annet anliggende i konfliktforståelse, er konfliktnivåer. Et viktig poeng for Sørensen og Grimsmo (2001) er at behovet for å bli sett og verdsatt har økt i det moderne arbeidslivet. Dette henviser også til konfliktpartenes nivå. Konflikter mellom ulike nivåer, som leder og medarbeider, er vertikale. Disse er asymmetriske hva gjelder makt og belastninger. Kategorien har trolig store mørketall. Den underordnede vil ofte være den svake parten. Det er ugreit å være i konflikt med lederen. Medarbeidere kan tie av frykt for sanksjoner, de kan sykemeldes eller avslutte arbeidsforholdet. Men lederrollen er også krevende, og ledere kan motarbeides i det stille. Vedtak kan saboteres av medarbeidere. Mellomledere skvises mellom over- og underordnende. Kunnskapsarbeidere opplever ikke alltid behov for ledelse. Noen arbeidsplasser har flere hierarkier side om side, for eksempel en faglig og en administrativ ledelse, eller to arbeidsgiverlinjer på samme arbeidsplass. Horisontale konflikter utspilles mellom to aktører på samme nivå.

Grimstad (2002) kategoriserer konflikter ut fra hvordan de forstås i arbeidsprosessen. Er det uenighet eller konfliktpotensial relatert til ulik forståelse av situasjonen, tiltak eller mål? Situasjonskonflikters kjerne er ulik definisjon av sakens kjerne og fakta, der partene har grunnleggende forskjeller i oppfatning av situasjonen. Ulike virkelighetsbeskrivelser konkurrerer. Tiltakskonflikter betegner forskjeller i valg av strategi for å nå et mål eller komme til rette med en situasjon. Dette kan henge sammen med fordelingskonflikter eller interessekonflikter hvor motsetninger skyldes fordeling av ressurser og goder som lønn, utstyr, lokaler eller oppgaver. Vedtak utfordres gjennom omkamper. Tiltakskonflikter kan ha et islett av politiske drakamper. Målkonflikter dreier seg om mål for virksomheten. Skjulte mål finnes i tillegg til formelle mål: Målforskyving innebærer at andre interesser enn de offisielle styrer en del av 
prioriteringen i virksomheten (Ekeland, 2014, s. 119). Utfordringen er at mål ofte er diffuse og mangetydige, for eksempel et mål som «kvalitet». Det gjelder ikke minst i verdikonflikter, hvor deltakerne kan bli prinsipielle, dogmatiske og lite imøtekommende. Argumentasjonen kan knyttes til egen personlige integritet. Til slutt bygger pseudokonflikter på misforståelser som kan oppklares, og har lite reelt innhold.

Som vi ser finnes det flere måter å klassifisere konflikter på. Her vil vi presentere kategoriseringer som er relevante for å forstå kirkens særlige utfordringer. Klassifisering av konflikter kan gi hjelp til å velge tilnærmingsmåte. Vi beskriver her kort fire konflikttyper som sier noe om konfliktenes sosiale arena.

En intrapersonlig konflikt betegner en persons indre konflikt hva gjelder beslutninger eller moralske spørsmål. Den angår ikke nødvendigvis andre, men indre spenninger kan bidra til sosiale konflikter. Interpersonlige konflikter refererer til konflikter mellom en person og en eller flere andre, og forekommer typisk på arbeidsplasser. Ekeland (2014, s. 92) beskriver disse som ansikt-til-ansikt-konstellasjoner. I intragruppekonflikter forklares ikke konflikten ut fra mellommenneskelige spenninger, men sees i lys av gruppen som aktørene tilhører. Gruppen er en sosial enhet med særskilte kjennetegn. I store grupper øker antallet relasjoner, og dynamikken internt kan gi næring til konflikter. Her påvirker struktur og prosess hverandre: «Samspillet mellom struktur og prosess er da gruppedynamikken» (Ekeland, 2014, s. 98). Gruppetenkning viser seg ofte i intergruppekonflikter. Begrepet betegner motsetninger mellom oss og de andre. Gruppen sosialiseres og utvikler en tendens til å overvurdere seg selv og posisjoner seg i opposisjon til andre. Internt samhold fører da til fiendebilder av andre grupper og unyanserte beskrivelser. Eksempler på slike konflikter på arbeidsplasser er spenninger mellom profesjoner, eller mellom profesjoner på den ene siden og ledelsen på den andre. Det er da viktig for ledere å minne om virksomhetens overordnede formål og verdier.

\section{Konflikthåndtering}

Grimstads (2002) andre begrepsmessige avklaring bidrar til å gjøre konflikter praktisk håndterbare. En konflikt er i seg selv verken positiv eller 
negativ, men gir gode eller dårlige følger ut fra hvordan de håndteres. Et viktig begrep her er konflikteskalering, hvor konflikten øker i omfang og alvorlighetsgrad, fra fred og uenighet til brudd og krig. I eskaleringen blir ofte en konflikt hardere og omfatter stadig flere sider av virksomheten. Det finnes altså både funksjonelle og dysfunksjonelle konflikter som kan påvises gjennom eskalering fra mindre uoverensstemmelser og misforstålser til verbale angrep, trusler, ultimatum, aggressive psykiske angrep og åpne handlinger som ødelegger for den andre (Langslet, 2002).

Grimstad (2002) poengterer at konfliktløsning lykkes bedre dersom ledere håndterer konflikter på rett tidspunkt. Det utfordrer lederes evne til timing. Det har skjedd en markant dreining i litteraturen fra å løse til å håndtere konflikter (Ekeland, 2014; Rognes, 2013). Dette har skjedd samtidig som utviklingen har gått fra et tradisjonelt til et mer moderne syn på konflikter i organisasjoner. Einarsen og Pedersen (2017) forstår konfliktløsning som å fjerne selve grunnlaget for konflikten, mens konflikthåndtering ikke nødvendigvis forandrer konfliktens innhold eller bakgrunn. Ledere må tenke prosessuelt, og ikke utelukkende fokusere på løsning. En annen strategi, LØFT, løsningsfokusert tilnærmingsmåte, retter oppmerksomheten mot løsningsfremmede handlinger snarere enn problematferd. Modellen har bakgrunn i kognitiv psykologi, og består i å lete etter hva som er positivt og forsterke positiv og ønsket atferd (Langslet, 2002).

Enhver konflikt er unik, og felles oppskrifter på konfliktløsning blir derfor teoretiske. Vi omtaler kort etablerte hovedmodeller innenfor konflikthåndtering slik det fremkommer hos Grimstad (2002). For det første er det viktig å vite hvordan ledere har ulike konfliktstrategier - fra integrasjon, konfrontasjon, unngåelse og kompromiss til ettergivelse. Konfliktforsker Jørn Kjell Rognes (2013) finner at norske ledere ikke unngår konflikter, men tar de opp gjennom samarbeidsorienterte strategier. En utbredt strategi er integrasjon, forstått som problemløsning i samarbeid med de underordnende. Konfrontasjon, å presse gjennom egne interesser til tross for motstand, brukes lite. Dette bekrefter norsk arbeidsliv som preget av likeverd og konsensus gjennom åpen dialog. Rognes’ undersøkelse viser at konfrontasjon og unngåelse øker når det er usikre omgivelser og stress (Rognes, 2013, s. 271). 
Grimstad (2002) identifiserer felleselementer i konflikthåndtering. Handlingsmetoden, som er kjent i HMS-metodikk, innebærer å legge vekt på hvordan en dialog som har brutt sammen kan gjenopprettes. En slik dialog handler ikke bare om å snakke sammen, men å anstrenge seg for å se den annens perspektiv i situasjonsbeskrivelse og forklaringer. Det forutsetter at ledere må skape arenaer der ikke noen mister ansikt, men hvor løsninger, beslutninger og gjennomføringer følges opp. Ledere bør analysere egne roller, muligheter og begrensninger. Man plikter å analysere situasjonen og ta beslutninger på eget grunnlag, samt vurdere om andre skal trekkes inn, eksempelvis å bidra til mekling.

\section{Konfliktforebygging}

Et tredje premiss hos Grimstad (2002) er at ledere må forholde seg til og forebygge konflikter som del av sitt arbeidsgiveransvar. Ettersom Den norske kirke har blitt selvstendig rettssubjekt, har den blitt ansvarlig arbeidsgiver og må forholde seg til arbeidsrettslovgivningen på en tydeligere og mer profesjonell måte enn før. Konflikthåndtering er tematisert i rammen av HR-ledelse, plassert innenfor den norske arbeidslivsmodellen og relatert til arbeidsrett og psykososialt arbeidsmiljø. Vi presenterer disse rammevilkårene i dette delkapitlet. Ledere må forholde seg til konflikter med to forankringspunkter (Grimstad, 2002). De må på den ene siden ta hensyn til rammene som lov- og avtaleverket gir, samtidig som god ledelse på den andre siden også fordrer skjønn og fortolkning av den aktuelle situasjonen. Ledere må altså nyttiggjøre seg både juss og psykologi. Manglende konflikthåndtering utgjør en risiko for helse-, miljø- og sikkerhetsarbeidet.

Fundamentet i den norske arbeidslivsmodellen er samarbeid mellom samfunnsaktører sentralt og mellom arbeidsgivere og arbeidstakere lokalt (Trygstad \& Hagen, 2007). Partssamarbeidet er representativt gjennom arbeidsgiver- og arbeidstakerforeninger, og nedfelt i lover, forskrifter og avtaleverk. Det andre er primært løpende og tillitsbasert, i tillegg til at det reguleres i lov- og avtaleverk. Arbeidsretten har et kollektivt og individuelt preg (Storeng et al., 2009) og har som hensikt å verne om den svake part, arbeidstakeren. Det skrives individuell arbeidsavtale, mens det kollektive er tariffavtalen mellom arbeidsgiver og fagforening. 
Et annet trekk ved norsk arbeidsliv, er individrespekt, konsensus og flate hierarkier. Modellen inneholder både regelstyring gjennom lov- og avtaleverk, budsjetter og instrukser, målstyring gjennom planer og rapportering og verdistyring gjennom involvering hvor den enkelte tar ansvar for helhet og prosesser. Den norske arbeidslivsmodellen skaper personlig engasjement, kreativitet og lojalitet, og er velegnet for kunnskapsarbeidere og profesjonsutøvere (Trygstad \& Hagen, 2007).

Et viktig punkt som Grimstad (2002) tematiserer, er at arbeidsmiljøloven gir føringer for hvordan arbeidsgiver skal tilrettelegge for et fullt forsvarlig arbeidsmiljø. Loven er å forstå som en samarbeidslov som regulerer medvirkning og forebygging. Ledere har styringsrett som betegner leders rett til å organisere, lede, fordele og kontrollere arbeidet. Gjennom fordeling av oppgaver, ansvar, informasjon og ressurser tilrettelegger ledere for ansattes arbeid og disponerer deres tid. Styringsrett er negativt avgrenset som en restkompetanse hvor det som ikke er påbudt eller forbudt, er mulig. Ansatte avgir noe av sin frihet ved inngåelse i et arbeidsforhold (Storeng et al., 2009, s. 10). Hovedansvaret for arbeidsmiljø ligger på arbeidsgiver, men er samtidig samarbeidsbasert. Det stilles krav både til fysisk og psykososialt arbeidsmiljø (Arbeidsmiljøloven, 2005, \$ 4-3, $\$ 4-4)$. Arbeid skal ifølge loven være helsefremmende.

Denne alminneliggjøringen av kirken som arbeidsplass, med overgangen fra særlover for kirkelige stillinger til demokratiske styringsorganer og daglig ledelse, innebar et brudd med mange kulturer på kirkelige arbeidsplasser. Det handlet om å ta tak i ting «slik de alltid var gjort» og skjelne mellom arbeidstid og fritid. Spørsmål som ble tatt opp, var for eksempel betydningen av «å stå til arbeidsgivers disposisjon» og «er det galt at jeg skaffer min egen vikar?». Sameksisterende, men ulike arbeidskulturer i staben kom til overflaten - spissformulert slik: De som ser det å arbeide i kirken som en vanlig jobb, og de som realiserer sitt kall til tjeneste gjennom kirkelig arbeid.

I tillegg til kjennskap og anvendelse av lov- og avtaleverk, understreker Grimstad (2002) at psykologisk innsikt også bidrar til konflikthåndtering. Både styringsrett og omsorgsplikt gjennom ledelse er påkrevd. God ledelse virker forebyggende når lederen følger arbeidet kontinuerlig og bidrar til god kommunikasjon. Lederes utfordring og lovpålagte oppgave er å 
muliggjøre samarbeid på tross av motsetninger. Oppsummert er et viktig anliggende å plassere konflikt innunder arbeidsgiveransvaret. Det gir en arbeidsrettslig forankring, og er ikke noe en arbeidsgiver kan abdisere fra. God lederpraksis i tråd med arbeidsmiljøloven skal forebygge konflikter.

\section{Konflikt som kirkelig tema 1980-2020}

Dette delkapitlet viser gjennom en kronologisk gjennomgang hvordan konflikter er tematisert i Den norske kirke. Noen konflikter i Den norske kirke får medieoppmerksomhet. Oppslagene kan gjenspeile at produktiv uenighet forveksles med destruktiv konflikt, eller omhandle hvordan ildsjelers engasjement eller ansattes idealisme hindrer samarbeid. Men ikke alle konflikter kommer frem i det offentlige lyset. Kirken er en kompleks organisasjon med et teologisk, demokratisk, samfunnsmessig, lokalt og nasjonalt mandat. Her møtes ulike interesser som muliggjør motstridende syn, inkludert teologiske oppfatninger, og dermed konflikter. Kirkereformene siden 1980-tallet har profesjonalisert kirken hva angår arbeidsrettslige rammer og innhold gjennom opphevelse av særlover, egne tariffavtaler, prioritering av skillet mellom arbeidstid og fritid samt innføring av nye ledelsesstrukturer. Kirken inngår i sivilsamfunnet og er samtidig underlagt offentlige styringslogikker. Potensialet for uenigheter og konflikter er stort. Konflikter i menigheter har store omkostninger både menneskelig, økonomisk og omdømmemessig. Det er derfor grunn til å ta arbeidet med konflikter seriøst og systematisk.

De nordiske folkekirkene utfordres av personalkonflikter. Svenska kyrkan har gjennomført flere arbeidsmiljøundersøkelser samt en nasjonal granskning av arbeidsmiljøet i svenske menigheter. Forskningen påviser utydelig oppgavefordeling, uklare ansvarsområder, manglende tiltak mot stress, høy arbeidsbelastning, liten tilrettelegging av arbeidet og manglende eller inkompetent ledelse. Det svenske Arbetsmarknadsverket utgav i 2007 rapporten Ett himla liv. Om kyrkans janusansikt:

Kyrkans grund hvilar på förestellningar om oendlig godhet, vilket er svårt att förena med forekomsten av mellanmenneskliga konflikter. Detta kan resultera i en uppfatning om at konflikter inte finnas och derför «sopar» dem under 
mattan och bortser fra dem. Risken er at konfliktene cementeras och brister som ursprungligen er att henföra til strukturella förhållande overgår til allvarliga individfrågor och til sökande efter syndebukkar. (Arbetsmarknadsverket, 2007, s. 3)

De nordiske folkekirkene deler holdningsmessige utfordringer knyttet til godhet og tilgivelse. Dette er forventninger som preger arbeidsmiljøet på tross av kirkenes ulike struktur - eksempelvis har både Svenska kyrkan og Finska kyrkan enhetlig arbeidsgiverlinje.

I Den norske kirke har Kirkerådet arbeidet med å etablere og definere kirkelige stillinger fra begynnelsen av 1980- årene. Prosessen innebar å få stillingene til å samarbeide samt avklare relasjonen både til menighetsrådet og til ledelse. Et tydelig uttrykk for dette er to hefter utgitt av KA, Samarbeid i menigheten (Grimstad, 1983a) og Transaksjonsanalyse i menigheten (Grimstad, 1983b), som vektlegger gode arbeidsfellesskap og samarbeidsrelasjoner for å kunne forebygge misforståelser og konflikter. Heftene tematiserer maktforhold, men advarer også mot falsk ydmykhet som kan hindre åpen og direkte konfliktløsning. Grimstad (1983a) argumenterer for verdsettende og lyttende ledelse som skaper trygghet. Men formaliteter knyttet til tillitsvalgte og verneombud samt arbeidsgivers ansvar for et fullt forsvarlig arbeidsmiljø, er fraværende. Hovedgrunnen er at kirken ikke fikk dette formelle ansvaret før gjennom kirkeloven av 1996.

Innføringen av kirkeloven var derfor en respons på flere utfordringer: uklare roller, lite fokus på formelle spilleregler i menighetene samt økte spenninger knyttet til usikkerhet om fremtidig organisering. I denne perioden bidro stiftskapellanene ved bispekontorene og KA til å løse samarbeidsproblemer og lokale konflikter. Det var lite systematisk arbeid, men enkelte konferanser søkte å belyse konflikter i kirken. Endringer og reformer utløser ofte både ledelsesfokus og økt konfliktpotensial. I det følgende ser vi på tre hovedfaser av endring med tilhørende konflikter fra kirkeloven ble innført i 1997.

\section{7-2010: Konflikter settes på kirkens dagsorden}

Denne fasen var preget av endringene som fulgte av kirkeloven (1996). Hele 7000 arbeidstakere lokalt ble virksomhetsoverdratt fra kommunene 
til fellesrådene, mens presteskapet forble statstjenestemenn. Menighetene fikk for første gang formalisert arbeidsgiveransvar og daglig ledelse. Konfliktnivået forble relativt høyt i flere staber med stort behov for opplæring. Det praktisk-teologiske seminar arrangerte konferansen «Personalkonflikt i kirken» i 1998 (Personalkonflikt i kirken - en konferanserapport, 1998). Sentrale temaer var «Teologisk perspektiv på fellesskap og konflikt», «Er kirken en spenningsfylt arbeidsplass?» og «Hvem har ansvar for å løse konflikter?». Konfliktløsningsråd i hvert bispedømme med ansvar for konfliktløsning ble foreslått, men ikke realisert.

En sentral kilde til kirkelige personalkonflikter er teologen Terje Torkelsens (2003) doktorgradsavhandling med tittelen På livet løs: En praktisk-teologisk studie av kirkelige medarbeideres erfaringer fra helsefarlige personalkonflikter i Den norske kirke. Avhandlingen bygger på tjue dybdeintervjuer gjennomført i 1998 og gir et tidsbilde. Intervjupersonene er valgt på bakgrunn av seks personalkonflikter i fire bispedømmer. Konfliktene var mangeårige, rammet flere ansatte og førte til høyt antall sykemeldinger, permisjoner og turnover i tillegg til en dramatisk nedgang i aktivitetsnivå og fremmøte i menighetene. Det er ikke konflikthåndtering som er avhandlingens tema, men kirkeansattes erfaringer.

Torkelsens (2003, s. 291) litteraturgjennomgang viser at lite hadde blitt publisert om konfliktforståelse i kirken: «Det eksisterer nærmest teoriløshet om personalkonflikter, særlig i Den norske kirke». Han etterlyste faglig refleksjon og tok til orde for en differensiert konfliktforståelse med symmetriske og asymmetriske personalkonflikter. I symmetriske konflikter, der makt og tillit balanserer, er det å snakke sammen en måte å håndtere konflikter på. I asymmetriske konflikter, der makt og tillit er i ubalanse, kan det å snakke sammen eskalere konflikten og gi helsemessige skader. Personer blir da invadert og misbrukt. Torkelsen påpekte at kirken i for stor grad hadde tro på dialogen og samtalen for å komme frem til enighet, også i konflikter med stor ubalanse mellom partenes makt og tillit. Asymmetriske konflikter krever andre grep enn samtalen. Et sentralt spørsmål er belysningen av maktmennesker og deres rolle i kirkelige konflikter. Torkelsen påpeker dette i sin anbefaling av løsningsmetoder i asymmetriske konflikter: adskillelse, ikke fellesskap. Dermed settes maktforhold under lupen, og arbeidsgiver har et ansvar 
for å aktivt gripe inn overfor destruktiv atferd for å beskytte kirkeansatte. En viktig lærdom i undersøkelsen er at ledere bør intervenere tidlig og arbeide forebyggende.

I 2002 ble det innført grunnopplæring i arbeidsmiljø for ledere i Den norske kirke gjennom et 40 timers kurs med helse-, miljø- og sikkerhetsarbeid (HMS) som bygget på allmenn konfliktteori og brukte stadig oppdaterte kilder (Ekeland, 2014; Sørensen \& Grimsmo, 2001). Generell organisasjonsteori og ledelsesteori (Nordhaug, 2002) dannet også et teoretisk grunnlag. Kurset la tydelig vekt på arbeidsrett, og inneholdt en egen kursdag om psykososialt arbeidsmiljø og konflikter. Kurset var nyskapende gjennom å være felles for begge kirkelige arbeidsgiverlinjer, og kursmateriellet (Grimstad, 2002) ble brukt som ressurs i kirkens egen kursing og undervisning av kirkeledere de kommende år. Publikasjoner fra Arbeidstilsynet om den norske samarbeidsmodellen ble også brukt for å normalisere behandlingen av kirkelige konflikter. Et kirkelig bidrag var Torkelsens Når mennesker krenkes (1998). En rekke kurs om HMS i samarbeid mellom Fagforbundet og Diakonhjemmets høgskole økte også kompetansen.

Perioden 1997-2010 kjennetegnes også av at de to arbeidsgiverlinjene, representert ved KA og Kirkedepartementet, så behovet for felles innsats og informasjon for å forebygge og håndtere konflikter. Det resulterte blant annet i brosjyrene Sett trivsel på dagsorden (2009) og Fruktbar uenighet eller farlig konflikt (2010). Der uttalte man i fellesskap at kirken hadde enkelte spesielle organisatoriske trekk som det var viktig at man håndterte godt og hadde bevissthet om. Dette medvirket til at de fleste bispedømmeråd utarbeidet forslag til håndtering av lokale arbeidskonflikter.

\section{0-2015: Konflikter som arbeidsmiljøutfordring}

I årene 2010-2015 gjennomførte flere bispedømmer og fellesråd arbeidsmiljøundersøkelser som viste fortsatt høyt konfliktnivå. Undersøkelsen som representerer størst bredde både geografisk og når det gjelder yrkesgrupper i kirken er Arbeid, helse og engasjement blant ansatte i Den norske kirke (Lau, 2012), en landsomfattende arbeidsmiljøundersøkelse bestilt av KA og Kirkedepartementet. Arbeidsforskningsinstituttet sto 
for gjennomføringen, der det ble etablert fire fokusgrupper blant ulike ansatte og sendt spørreskjema til 6109 ansatte med en svarprosent på $48,9 \%$. Hensikten var å kartlegge hva som opplevdes utfordrende og belønnende med arbeidet i kirken, og undersøkelsen gir et bilde av helheten i kirken som arbeidsplass i tillegg til verdifull kunnskap om konflikter i kirken.

Undersøkelsen kartlegger det psykososiale arbeidsmiljøet ved å identifisere helsefremmende eller helseskadelige forhold. Rapporten konkluderer med at mange opplever et godt arbeidsmiljø i kirken. Det er fire former for utfordrende arbeidsforhold: arbeidskrav, lederutydelighet, eksterne forventninger og konflikter. Ansatte rapporterte om konflikter med «brukere», samarbeidsutfordringer med frivillige og menighetsråd med urealistiske forventninger. Det var vanskelig å avspasere arbeidstid, og ved sykdom hopet arbeidet seg opp. Andre problemer som trekkes frem er dårlig økonomi, uklarhet om arbeidsoppgavenes innhold og utydelige ledere. $27 \%$ oppgav at det var vanskelige å vite hvilken leder man skulle forholde seg til når det gjelder visjoner. $17 \%$ rapporterte om utydelighet om arbeidsoppgaver. Halvparten av respondentene opplevde konstant tidspress på grunn av stor arbeidsmengde og ansvar, samt arbeide utover vanlig arbeidstid (Lau, 2012, s. 29). $60 \%$ mente at de to arbeidsgiverlinjene hadde ulike visjoner, men at lederutydelighet grunnet to linjer ikke var særlig belastende. To av tre rapporterte om både personkonflikter og faglige konflikter (Lau, 2012, s. 20). Rapporten omtaler det som et «tankekors at over $10 \%$ opplever at konflikter på arbeidsplassen er en belastning for dem. Arbeidsmiljøloven er helt klar på at det er arbeidsgiver som har ansvaret for å fange opp og håndtere konflikter på arbeidsplassen» (Lau, 2012, s. 35).

At $17 \%$ av respondentene opplever utbrenthet er atskillig høyere enn kommunesektorens $13 \%$. De som rapporterte om utbrenthet, har høyere skår på jobbkrav, lederutydelighet og eksterne forventinger som belastende. Blant de som selv opplevde konflikter, var $45 \%$ utbrent. Av de uten konflikter, var bare 14 \% utbrent. Også ifølge en undersøkelse av norske prester i 2003 (Nordeide et al., 2008), er det høy grad av sammenheng mellom å oppleve personlige konflikter med andre og symptomer på utbrenthet. Her deltok 787 prester i en spørreskjemaundersøkelse, samt 43 prester i en intervjustudie. Nordeide et al. (2008) påviser at ansatte 
som er stresset lettere kommer i konflikt med andre, men at konflikter i seg selv ikke fører til utbrenthet.

Arbeidsmiljøundersøkelsen Arbeid, helse og engasjement blant ansatte i Den norske kirke (Lau, 2012) viser også belønnende elementer i å arbeide i kirken: anerkjennelse, karrieremuligheter, jobbsikkerhet, trosfellesskap og jobbautonomi. De ansatte rapporterte om mange positive forhold i arbeidet, som høy grad av frihet i jobbutførelsen (83\%) og fleksibel arbeidstid. $56 \%$ opplevde at arbeidet var et kall, at de fikk benyttet kreativitet og fikk utviklet seg faglig. De kan fortelle om opplevelse av å være del av noe større (85\%), og at kirken er viktig for folk. $64 \%$ opplevde et trosfellesskap med kolleger og at man skapte noe sammen med andre i godt samarbeid.

Som en oppfølging av arbeidsmiljøundersøkelsen ble det etablert et felles prosjekt for å øke kompetansen hos kirkeledere. Heftet Konfliktforståelse og konflikthåndtering i Den norske (Grimstad, 2012) ble innført i kirkelig kursing. Også dette heftet er bygget opp etter tredelingen konfliktforståelse, konfliktforebygging og konflikthåndtering (jf. Grimstad, 2002). Publikasjonen viser til flere årsaker til høyt konfliktnivå $i$ kirken: Utydelige eller manglende felles mål; lite forståelse for ledelse og styringsorganer; manglende eller uklare strukturer; svak rolleforståelse og uklare ansvarsområder; manglende evne og vilje til reelt samarbeid; mangel på forståelse for effektivitet.

\section{5-2020: Konflikt som naturlig del av arbeidslivet}

En tredje fase er tidsrommet 2015-2020, hvor det skjer en endring i Den norske kirkes tilnærmingsmåte til konflikter som et eklektisk fag. De foregående fasene la vekt på kontekstuelle sider ved konflikter i kirken. Denne fasen nedtoner det særegne ved kirken, og plasserte kirkelige konflikter i rammen av sivilsamfunnet.

Denne fasen viser hvordan det har skjedd endringer i synet på konflikter i arbeidslivet de siste tretti år. Dysfunksjonelle resultater er energitap, misbruk av tid og potensielt føre til skader fysisk eller psykososialt. Et tradisjonelt syn på konflikter innebærer at konflikt kan og bør unngås. 
I dette perspektivet er konflikt forårsaket av vanskelige personer. Et moderne syn på konflikter er derimot kjennetegnet av en forståelse av at konflikter er en uunngåelig og nødvendig del av et moderne arbeidsliv som en naturlig del av all utvikling og endring. Et moderat nivå er derfor optimalt i en sunn organisasjon. Positive sider ved konflikter i organisasjoner kommer til uttrykk gjennom skapende interesseforskjeller som kan bidra til bedre beslutninger, større åpenhet og engasjement. Konflikter anses som informative, og gir organisasjoner mulighet til selvkritikk og korrigering. De kan redusere problemer, gi ny innsikt og gjenskape gode relasjoner. Faglig uenighet gir spenninger som kan drive arbeidet fremover. I et moderne syn på konflikter er det avgjørende hvordan ledere håndterer uenigheter og konflikter, ikke hvordan man unngår dem. Som vår analyse har vist, har et positivt syn på konflikter i liten grad preget Den norske kirke. Samtidig er det viktig å identifisere dysfunksjonelle konflikter som ødelegger enkeltpersoner og lammer virksomheten. Sentralt i dette ligger forståelsen og analysen av når en konflikt går fra å være skapende til å være skadelig. Arbeidslivsforskerne Hanne Heen og Robert Salomon (2018) kategoriserer konflikter som manifeste, latente og skjulte konflikter. De er opptatt av at organisasjoner er avhengige av en viss grad av spenning og uenighet for å utvikle seg. Mange av spenningene er latente.

Konfliktforskere som i større grad benytter sosialpsykologiske tilnærminger (Ekeland, 2014) vektlegger rollebegrepet i sosiale samspill. Som vi har sett, har rollebegrepet utgjort en viktig del av kirkens tematisering av både ledelse og konflikter. Tilknytningsteori og oppvekst kan bidra til å kaste lys over relasjoner og hvordan personligheten utvikles i samspill med relevante andre. Denne retningen påpeker at vi må forstå både person og situasjon og samspillet mellom dem. Når ledere veksler mellom ulike perspektiver - som individ, arbeidsplass og samfunn - på analytisk nivå, gir det større helhetsbilde. Det innebærer sterkere vekt på sosiale roller enn på individuelle personlighetstrekk. Noen sentrale innsikter i denne tradisjonen er at sosiale roller som lederrolle og faglig rolle krever avklaring og tydeliggjøring. Manglende rolleforståelse kan være grunnlag for konflikter. Dette er særlig aktuelt i en kompleks organisasjon som Den norske kirke. 
Rolleforståelse henger sammen med å se sitt eget og andres handlingsrom. Siden roller kan forstås som summen av forventninger til en gitt sosial posisjon, rommer begrepet verdier på arbeidsplassen, takt og tone, og hva som regnes som passende eller upassende atferd. Ulike personer identifiserer seg i varierende grad med normene. Forskjellige roller og verdier lever side om side og skaper usikkerhet og grobunn for konflikter. Noen personer kan oppleves krevende å forholde seg til. Det kan være personer som mer eller mindre bevisst og tilsiktet bruker falsk smiger, egen hjelpeløshet, selvhevdelse, sladder eller baktalelse. Personlighetsforstyrrelser finnes, men bruk av diagnoser på andre er lite konstruktivt. Dette er ikke mindre fremtredende i religiøse organisasjoner hvor relasjoner og personlig trosoverbevisning preger arbeid. I denne teoretiske tradisjonen er det viktig å håndtere uenigheter og konflikter systemisk, det vil si med vekt på samspill og helhet.

Oppsummert er et viktig poeng at konflikter er komplekse, og at det ikke finnes noen enkel løsning. Derfor er det viktig å anvende både strukturelle, sosiologiske, psykologiske og teologiske innfallsvinkler for å komme til rette med konflikter i kirken.

\section{Drøfting - kirkens kultur og struktur relatert til konflikt}

Av det foregående er det tydelig at konflikter påvirkes av struktur og kultur. Følgende delkapittel drøfter først kultursiden og ser deretter på tydeliggjøring og profesjonalisering av strukturer med henblikk på konflikter. Disse perspektivene sammenholdes i eksempelet kjønn og konflikt.

\section{Kirkens kultur og konflikter}

Grimstad (2002) omtaler kirkelig ledelseskultur som en «hinte-og-håpe-kultur», der ledere hintet og håpet at noen forstod. I Konflikter i kirken (2002) etterlyser Grimstad klarere strukturer, mer åpenhet, tydeligere ledelse og et større individfokus for å kunne komme til rette med konflikter (se også Løvås, 1999; Stoltenberg, 2011). 
Torkelsens (2003) doktorgradsprosjekt, omtalt over, ga støtet til et intensivert arbeid fra kirkens side. Han beskrev kultursiden av kirkelige konflikter som «ta alt i beste mening-mentalitet» som bunner i at kirkens positive verdier som skal fremme gode relasjoner (Torkelsen, 2003, s. 84). Ønsket om harmoni samsvarer med Bibelens idealer om det gode liv, illustrert gjennom fortellingen om den barmhjertige samaritan og det «å gå en ekstra mil» for andre. Men i konflikter kan idealene bidra til fortielse og et krav om taushet (Torkelsen, 2003, s. 82). Torkelsens informanter med erfaringer fra helsefarlige konflikter omtaler «snillhetskultur» og «overdreven forsiktighet» med lite rom for å komme med korreksjoner, og der kritikk kan bli oppfattet som å snakke stygt om andre. Avhandlingen dokumenterer også asymmetriske rollemønstre hvor prestene fremstår mer uangripelige enn andre kirkeansatte (Torkelsen, 2003, s. 83). Prester som ledere tenderte å identifisere seg som sjelesørgere fremfor å håndtere konflikter. Opposisjon kunne bli likestilt med ulydighet mot den åndelige autoriteten. Disse særegne kirkelige kulturelle faktorene kan føre til konfliktangst og handlingslammelse hvor man velger å lide i stillhet, ikke minst av hensyn til menighetens omdømme. Intervjuene viste at verdiene tilgivelse, overbærenhet, lojalitet og tålmodighet gjorde at kirken som arbeidsplass er særlig sårbar for personalkonflikter og mobbing. Mange kjenner en sterk lojalitet og forpliktelse på å fremstille kirken i best mulig lys utad:

Det er noe med det at vi skal elske hverandre, vende det andre kinnet til og ikke snakke stygt om hverandre. Det er jo grunnleggende, heldigvis. Men det gjorde også at det gikk lang tid før vi våget å snakke om konflikter. For slikt snakker vi jo ikke om. Det gjør kirken særlig sårbar i slike konflikter. (Torkelsen, 2003, s. 82)

Et annet kjennetegn er åndeliggjøring av konflikter, der man i en konfliktsituasjon for eksempel siterer bibelvers:

I begynnelsen var det mange forsøk innad i staben på løse dette på en åndelig måte. Vi skulle ha et åndelig felleskap. Det skulle skje en forsoning. I kirken skal man være forsonlig, derfor er det også farlig å ta opp konflikter. (Torkelsen, 2003, s. 84) 
Andre kjennetegn i kirkelig kultur er følelsen av personlig forpliktelse og autoritetsrespekt. Grimstad (2002) omtaler en viss «snillisme» og konfliktskyhet. Torkelsen (2003) illustrerer samme fenomener med at arbeidsgiver satte inn samtaletilbud og sjelesorg fremfor konflikthåndtering. Dialog og gjensidig meningsutveksling er lite hensiktsmessig når maktforholdet er asymmetrisk.

Ifølge informantene i Laus (2012) arbeidsmiljøundersøkelse, er det fortsatt lite skille mellom arbeidstid og fritid i kirken, lite systematiske tilbakemeldinger og til dels dårlig ledelse. Både Torkelsens (2003) undersøkelse og arbeidsmiljøundersøkelsen (Lau, 2012) har gitt viktige innsikter og utgjør klare referansepunkter for forståelse av konflikter i kirken. De viser også hvordan struktur og kultur må spille sammen for å komme til rette med konflikter.

\section{Kirkens struktur og konflikter}

Vår analyse viser at flere tematiserer strukturperspektivet som forklaringsmodell kontra å individualisere konflikter. Konflikter kan følge av strukturelle spenninger mellom bærere av ulike interesser. Som vår kronologiske gjennomgang viser, preges 1990-tallet av lite vekt på struktur både i den rådsbaserte virksomheten og i geistlig tjeneste. Det var behov for kompetanse på å bruke formelle aktører og HMS-rutiner for å forebygge og håndtere konflikter. Grimstad (2002) påpeker at kravet om enighet og lojalitet fører til en tendens til for raskt å beskrive naturlig uenighet som konflikt. Ved å gjøre noe til en konflikt skjer det en innsnevring av åpenhet og kreativitet. Perioden var også preget av mangel på utviklede rutiner for å forebygge og håndtere konflikter, samt uklare roller og rolleforståelse internt i linjene og mellom linjene: «En mer eller mindre bevisst strategi for å opprettholde eksisterende atferd og kultur kan være å opprettholde uklare strukturer. Uklare strukturer gir de ansatte som har uformell makt og er flinke til å manipulere, gode muligheter» (Grimstad, 2002, s. 32).

Grimstad (2002, s. 43) påpeker videre at uklare strukturer ikke er den eneste årsak til krevende personalkonflikter, men det er på sikt viktig å etablere en klarere og mer enhetlig struktur, en felles arbeidsgiver for 
alle ansatte i lokalmenigheten og en profesjonell organisasjon som er nær nok menighetene til å håndtere konflikter. Konflikterfaringer kretser rundt noen klare temaer. Uklare forventninger kan bidra til konflikter. Slitenhet og utbrenthet gjør folk lite fleksible. Lav selvfølelse gjør en sårbar for kritikk. Kirkeansatte kan oppleve kollisjon mellom kall og styringslogikk. Det er lite villighet til å bytte arbeidsplass, gjerne med henvisning at man da skuffer mange. Også Torkelsen (2003) omtaler strukturelle faktorer ved kirken, eksempelvis bruk av gjentatte samtaleprosesser som konflikthåndtering. Videre påpeker han tilbakeholdenhet i å plassere ansvar, unnvikelse fra arbeidsgiver og frykt for å spørre. Videre fant Torkelsen i sin studie praktisering av systemlojalitet, særlig kollegialitet i embetslinjen (2003, s. 101). Også i arbeidsmiljøundersøkelsen (Lau, 2012) ble lederutydelighet og flere arbeidsgiverlinjer fremhevet som utfordringer ved arbeid i Den norske kirke. Lederen kan bidra til helsefremmende arbeidsplasser. Sentralt i dette står å avklare aktørenes roller og oppgaver.

Oppsummert har den tydelige struktureringen i begge arbeidsgiverlinjene fra midten av 1990-tallet bidratt til større profesjonalisering av kirken som arbeidsplass. Grimstad (2012) sammenfatter utviklingen gjennom fire trekk. For det første har det vært en utvikling fra fragmenterte menigheter og uoversiktlig fordeling av roller, oppgaver og ansvar til to systemer. Det vil si at lokalt tilsatte med lokale råd som styringsorganer på den ene siden og en geistlig linje med styring og ledelse gjennom biskop og prost på den andre siden. For det andre har det vært en utvikling fra særlover for stillinger med stor selvstendighet til formalisering av arbeidsgiveransvar. For det tredje ser vi endring fra personalomsorg til personalpolitikk og arbeidsgiverpolitikk. For det fjerde har det skjedd en endring fra frykt for arbeidstakerorganisasjoner til respekt og tillit i konfliktsaker. Uavhengig av årsaksforhold, viser ulike teorier om konflikt at en uklar organisasjonsstruktur med utydelige maktforhold øker konfliktnivået (Ekeland, 2014). Oppstår konflikter på en arbeidsplass, er rask tilgang til eller gjennomarbeidede arenaer for konflikthåndtering avgjørende. Det ordinære arbeidsgiveransvaret er den primære konfliktløsningsmekanismen i kirken. 


\section{Konflikt og kjønn}

Avslutningsvis i denne drøftingen, vil vi gi et eksempel på et tema som illustrerer sammenvevingen av kultur og struktur i kirken; kjønn og konflikt. I arbeidslivet er det stor forskjell mellom arbeidsplasser når det gjelder hvilken betydning som tillegges kjønn (Heen \& Salomon, 2018). Noen steder er det nærmest et en-til-en-forhold mellom yrke og hierarkisk posisjon og kjønn. Fra 1990 har kirken som arbeidsplass gjennomgått store endringer både strukturelt og kulturelt. Ikke minst gjelder dette prestetjenesten lokalt og tilsvarende hierarkiske posisjoner. Frem til 1993 var det kun mannlige biskoper, men i 2020 ble det kjønnsbalanse. Lokalt er det tilnærmet kjønnsbalanse i de fleste stillingskategoriene. Strukturelt har det skjedd endringer gjennom aktivt å fremme tiltak som innebærer likestilling gjennom stillingsutlysninger og tilsettinger. Det er utført forskning for å finne ut om kjønn er avgjørende for hvorvidt man kan leve i konflikt eller om det er ulike strategier i møte med konflikt (Heen \& Salomon, 2018).

Rapporter fra kirken tyder på at kvinner har funnet seg i å bli sett på som et problem og ikke bli akseptert. Kulturelt har det vært lokale konflikter knyttet til at noen av teologiske grunner har reservert seg mot kollegafellesskap eller gudstjenestefellesskap med kvinner. Fra 1978 regulerte Presteforeningens «kjøreregler» slike forhold. Formelt opphevet Presteforeningen kjøregelene i 2004, men de har uoffisielt blitt praktisert. Noen kvinnelige prester har opplevd situasjonen konfliktfylt, og stilltiende levd med at andre kolleger ikke har anerkjent deres tjeneste. Lokale konflikter der prester ønsket å reservere seg medførte at Bispemøtet i 2020 kom med en uttalelse om at ingen i sin tjeneste kunne reservere seg mot kolleger. Dersom noen opplevde dette, skulle det tas opp med biskopen. Arbeidsgiver har en aktivitetsplikt for å forhindre at slike episoder oppstår. Kirkemøtets vedtak om likekjønnet ekteskap har utløst konflikter der personer tilhørende ulike teologiske standpunkter har skapt krevende arbeidssituasjoner. En rapport utarbeidet av KIFO og Fafo (Elgvin et al., 2020) belyser arbeidsforhold for LHBT-personer i norske menigheter. Hovedfunnene viste at arbeidsmiljøet vurderes positivt av de fleste som opplever støtte og tilhørighet på arbeidsplassen. Men samtidig oppleves det belastende å tilhøre en gruppe som får 
livet sitt diskutert. Hver femte LHBT-respondent oppga å ha opplevd diskriminering.

Den norske kirke har omkring 8000 ansatte som representerer et mangfold. Undervisningspersonell og diakoner har vokst i antall de siste femti årene og kommet i tillegg til prester og kirkemusikere. Fremveksten av daglige ledere har tilført kirken en rekke nye yrkesbakgrunner. De tradisjonelle gruppene med mye kompetanse, men ikke formalisert utdanning, er kirketjenere, gravere og kontorpersonell. Sosiologiske forskjeller, og inndeling i A- og B-lag, har konfliktpotensial. Sentralt i dette er opplevelsen av verdi og å beherske kulturelle koder. Det er et lederansvar å fordele oppmerksomhet, gi støtte og oppmuntring.

\section{Konklusjon}

Kapitlet har drøftet spørsmålet: Hvordan er konflikter i Den norske kirke tematisert i perioden 1980-2020, og hvilke ledelsesutfordringer gir konflikter $i$ et kirkelig arbeidsmiljø? Vår gjennomgang viser at kirken, også når det gjelder konflikter, forstås som en del av sivilsamfunnet som reguleres av offentlig lovgivning. Kirken har trukket veksler på allmenn teori om konflikter. Et første hovedfunn som viser utviklingen i denne 40-årsperioden, er en tydeligere oppfatning av det organisatoriske arbeidsmiljøets betydning for konflikter. Fremfor å være overlatt til konfliktpartene, har temaet blitt innvevet i arbeidsgiveransvaret. Konflikt er tematisert gjennom forebyggende tiltak og rutiner for håndtering. Utviklingen inneholder momenter som mer vekt på samarbeidsmodell i håndteringer, stadig mer allmenn konfliktlitteratur både hva gjelder struktur og kultur, økt fokus på organisatorisk arbeidsmiljø og lederkompetanse i konflikthåndtering.

Et annet hovedfunn er at selve konfliktsynet også har endret seg. Som vi har sett, har KA bidratt vesentlig til å sette konflikter på dagsorden i kirken. Allmenn litteratur om konflikter har sammen med kirkelige publikasjoner (Grimstad, 2002, 2012; Torkelsen, 2003) hatt omfattende kursing som en viktig formidlingsarena. Siden 2010 har denne utdanningen vært i samarbeid med daværende Diakonhjemmet høgskole med bruk av sosialpsykologiske tilnærminger, HR-ledelse, HMS-metodikk og 
rolleteori. Tredelingen med konfliktforståelse, konfliktforebygging og konflikthåndtering har gitt redskaper til å tematisere og komme til rette med konflikter. En eklektisk holdning har bidratt til ulike synsvinkler og gitt ledere økt repertoar for å hanskes med konflikter. Konfliktforståelse handler om å skjerpe blikket for hva som egentlig skjer i konflikter og hvordan de involverte og arbeidet preget av konflikter. Dette utgjør bakgrunnen for å se på konfliktløsningsmodeller som lederredskaper. Det har vært en voksende erkjennelse at kirkeledere har et særlig ansvar hva gjelder konflikter for å kunne sikre positive konsekvenser for arbeidsmiljø, effektivitet og kvalitet. Konflikter er ikke ødeleggende i seg selv, men mangel på kompetanse til å håndtere og forebygge kan være destruktivt. Hensikten med konflikthåndtering er å sørge for at konflikter tas tak i, sees fra flere sider og ivaretar aktørene underveis og etter.

Like fullt tegner det seg et bilde av en organisasjon i fortsatt utvikling med særlige utfordringer. Videre tiltak for å komme til rette med konflikter, er å styrke tydeligheten i det organisatoriske arbeidsmiljøet. Et felles arbeidsgiveransvar kan forebygge kjente risikofaktorer for dysfunksjonelle konflikter og mobbing - som mangelfullt og dårlig organisatorisk arbeidsmiljø, fraværende og utydelig ledelse og et psykososialt arbeidsmiljø preget av usikkerhet og manglende kreativitet og utviklingsmuligheter. En kultur preget idealer om grenseløs godhet og maktbruk i fromhetens navn, vil være en kontinuerlig utfordring. I religiøse organisasjoner er det også viktig å utvikle en maktkritisk kultur til bruk av fromhet og religion som undertrykkende elementer. Nordeide et al. (2008, s. 166) påpeker også viktige lederoppgaver for å hindre utbrenthet og konflikter. Ledertydelighet består i å klargjøre mål og prioritere, avgrense arbeidsoppgaver, motivere og inspirere, samt veilede i konflikthåndtering. Løsning ligger i noen tilfeller hos partene selv, men ord kan stå mot ord. Mange konflikter lar seg ikke løse ved dialog. Det gjenstår også en innsats for å styrke lederes forståelse for sitt ansvar for konflikthåndtering og arbeidsmiljø. En videre avklaring i forholdet mellom tilsynsansvar og arbeidsgiveransvar er også nødvendig. Tilsynet er uoppgivelig for kirken og har både en proaktiv og reaktiv rolle. Likevel finner vi at personal- og konfliktbehandling må baseres på arbeidslivets spilleregler og verdier som transparens, kontradiksjon og likebehandling. 


\section{Referanser}

Arbeidsmiljøloven. (2005). Lov om arbeidsmiljø, arbeidstid og stillingsvern mv. (LOV-2005-06-17-62). https://lovdata.no/lov/2005-06-17-62

Arbetsmarknadsverket. (2007). Ett himla liv. Om kyrkans janusansikt. Stockholm: Arbetsmarknadsverket.

Einarsen, S. \& Pedersen, H. (2017). Håndtering av konflikter og trakassering $i$ arbeidslivet. Jus og psykologi. Gyldendal Akademisk.

Ekeland, T.-J. (2014). Konflikt og konfliktforståelse. For helse og sosialarbeidere. Gyldendal Akademisk.

Elgvin, O., Grønningsæter, A. B. \& Larsen, E. N. (2020). Å vore en sak. LHBT+: holdninger og arbeidsmiljø $i$ Kirken (Fafo-rapport 2020:20). Fafo. https://www.fafo. no/en/publications/fafo-reports/item/a-vaere-en-sak

Grimstad, F. (1983a). Samarbeid i menigheten. Kirkerådet.

Grimstad, F. (1983b). Transaksjonsanalyse i menigheten. Kirkerådet.

Grimstad, F. (Red.). (2002). Konflikter i kirken. En artikkelsamling om forståelse, håndtering og forebygging av konflikter. KA Kirkelig arbeidsgiver-og interesseorganisasjon.

Grimstad, F. (2012). Konfliktforståelse og konflikthåndtering i Den norske kirke. KA Kirkelig arbeidsgiver- og interesserorganisasjon.

Heen, H. \& Salomon, R. (2018). Varme konflikter i arbeidslivet. Organisatoriske perspektiver og håndteringsmetoder. Gyldendal.

Jacobsen, D. I. \& Thorsvik, J. (2019). Hvordan organisasjoner fungerer. Fagbokforlaget.

Langslet, G. J. (2002). LØFT for ledere. Løsningsfokusert tilnoerming til typiske ledelsesutfordringer. Gyldendal Akademisk.

Lau, B. (2012). Arbeid, helse og engasjement blant ansatte i Den norske kirke. Arbeidsforskningsinstituttet.

Løvås, E. (1999). Det farlige maktmennesket. Luther forlag.

Nordeide, I. H., Skogstad, A. \& Einarsen, S. (2008). Jeg er jo ikke Jesus heller! Arbeidsmiljø og utbrenthet blant norske prester. Fagbokforlaget.

Nordhaug, O. (2002). LMR. Ledelse av menneskelige ressurser. Målrettet personal- og kompetanseledelse. Universitetsforlaget.

Personalkonflikt i kirken - en konferanserapport. (1998). Det praktisk-teologiske seminar, Teologisk fakultet, Universitetet i Oslo.

Rognes, J. K. (2013). Konfliktledelse. I R. Rønning, W. Brochs-Haukedal, L. Glasø \& S. Berge Matthiesen (Red.), Livet som leder. Lederundersøkelsen 3.0 (s. 253-271). Fagbokforlaget.

Stoltenberg, S. R. (2011). Når fellesskapet belastes. Om medarbeiderkonflikter i menighet og forsamling. Luther forlag.

Storeng, N. H., Beck, T. H. \& Due Lund, A. (2009). Arbeidsrett. Cappelen Akademisk Forlag. 
Sørensen, B. A. \& Grimsmo, A. (2001). Varme og kalde konflikter i det nye arbeidslivet. Tiden norsk forlag.

Torkelsen, T. (1998). Når mennesker krenkes. Helsefarlige personalkonflikter i kirken. Genesis forlag.

Torkelsen, T. (2003). På livet løs. En praktisk-teologisk studie av kirkelige medarbeideres erfaringer fra helsefarlige personalkonflikter i Den norske kirke [Doktorgradsavhandling]. Tapir.

Trygstad, S. C. \& Hagen, I. M. (2007). Ledere i den norske modellen. Arbeidsforskningsinstituttet. 


\section{Om forfatterne}

Stephen Sirris, ph.d., arbeider som førsteamanuensis ved Fakultet for teologi, diakoni og ledelsesfag, VID vitenskapelige høgskole, Oslo. Han er studieleder for masterprogrammet i verdibasert ledelse og leder ved Senter for verdibasert ledelse og innovasjon. Han har arbeidserfaring som prest og som kantor i Den norske kirke. Han har særlig forsket på organisering og ledelse av profesjonelt og frivillig arbeid i ulike sivilsamfunnsorganisasjoner.

Harald Askeland, dr.philos. \& ph.d., innehar stilling som professor ved Fakultet for teologi, diakoni og ledelsesfag, VID vitenskapelige høgskole, Oslo. Han har omfattende undervisningserfaring fra masterstudiet i verdibasert ledelse ved VID. I 2020-2022 er han i permisjon, og er fagdirektør i KA Arbeidsgiverorganisasjon for kirkelige virksomheter. Han har særlig forsket på reformer og endring i kirke og menighet, samt på lederroller og ledelsespraksis i kirke og diakonale helseinstitusjoner.

Frank Grimstad, cand.philol., er høgskolelektor emeritus ved Fakultet for teologi, diakoni og ledelsesfag, VID vitenskapelige høgskole, Oslo. Han har arbeidserfaring som kateket, avdelingsleder i Kirkerådet og som administrerende direktør i KA Arbeidsgiverorganisasjon for kirkelige virksomheter. Han har lang erfaring som foreleser innenfor kirkelig ledelse og organisering og som forfatter av artikler og veiledningsmateriell.

Mildrid Fiske, master i verdibasert ledelse fra VID vitenskapelige høgskole, er kirkeverge i Kristiansund. Hun har bred og lang ledererfaring fra ulike organisasjoner. I sitt mastergradsprosjekt forsket hun på kirkevergers lederrolle med vekt på rollens utvikling de siste to tiår. 
Åslaug Styve Mjånes, master i verdibasert ledelse fra VID vitenskapelige høgskole, arbeider som seniorkonsulent ved HR-avdelingen ved Universitetet i Bergen. Hun har lang yrkeserfaring fra Den norske kirke, blant annet fem år som assisterende kirkeverge i Voss kirkelige fellesråd. I sitt mastergradsprosjekt forsket hun på sentrale sider ved lokale kirkelige lederroller med vekt på proste- og kirkevergerollen. 